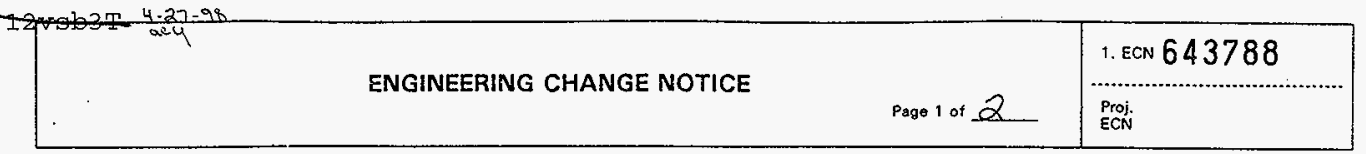

\begin{tabular}{|c|c|c|c|c|c|c|}
\hline \multirow{3}{*}{$\begin{array}{l}\text { 2. ECN Category } \\
\text { (mark one) } \\
\text { Supplemental } \\
\text { Direct Revision } \\
\text { Change ECN } \\
\text { Temporary } \\
\text { Standby } \\
\text { Supersedure } \\
\text { Cancel/Void }\end{array}$} & \multirow{3}{*}{$\begin{array}{r}{[]} \\
{[X]} \\
{[]} \\
{[]} \\
{[]} \\
{[]} \\
{[]}\end{array}$} & \multicolumn{2}{|c|}{$\begin{array}{l}\text { 3. Originator's Name, organization, MSIN, } \\
\text { and Telephone No. } \\
\text { Jim G. Field, Data Assessment } \\
\text { and Interpretation. R2-12. 376- } \\
3753\end{array}$} & \multicolumn{2}{|c|}{$\begin{array}{l}\text { 4. USQ Required? } \\
{[] \text { Yes }[X] \text { No }}\end{array}$} & $\begin{array}{l}\text { 5. Date } \\
04 / 27 / 98\end{array}$ \\
\hline & & \multicolumn{2}{|c|}{$\begin{array}{l}\text { 6. Project Title/No./Work order No. } \\
\text { Tank 241-T-105 }\end{array}$} & \multicolumn{2}{|c|}{$\begin{array}{l}\text { 7. Bldg./Sys./Fac. No. } \\
\text { 241-T-105 }\end{array}$} & $\begin{array}{l}\text { 8. Approval Designator } \\
N / A\end{array}$ \\
\hline & & \multicolumn{2}{|c|}{$\begin{array}{l}\text { 9. Document Numbers Changed by this ECN } \\
\text { (includes sheet no. and rev.) } 2 \text { - } 18-98 \\
\text { HNF-SD-WM-ER-369, Rev. R I-A }\end{array}$} & \multicolumn{2}{|c|}{$\begin{array}{l}\text { 10. Related ECN No(s). } \\
\text { ECNs: } 635417 \text {, } \\
635536\end{array}$} & $\begin{array}{l}\text { 11. Related PO No. } \\
\text { N/A }\end{array}$ \\
\hline \multirow{2}{*}{\multicolumn{2}{|c|}{$\begin{array}{l}\text { 12a. Modification Work } \\
\text { [] Yes (fill out Blk. } \\
12 b) \\
{[X] \text { No (NA Blks, 12b, }} \\
12 c, 12 \mathrm{~d} \text { ) }\end{array}$}} & \multirow[t]{2}{*}{$\begin{array}{l}\text { 12b. Work Package } \\
\text { No. } \\
\text { N/A }\end{array}$} & \multicolumn{2}{|c|}{$\begin{array}{l}\text { 12c. Modification Work Complete } \\
\qquad N / A\end{array}$} & \multicolumn{2}{|c|}{$\begin{array}{l}\text { 12d. Restored to Original Condi- } \\
\text { tion (Temp. or Standby ECN only) } \\
\text { N/A }\end{array}$} \\
\hline & & & \multicolumn{2}{|c|}{$\begin{array}{c}\text { Design Authority/Cog. Engineer } \\
\text { Signature \& Date }\end{array}$} & \multicolumn{2}{|c|}{$\begin{array}{l}\text { Design Authority/Cog. Eng ineer } \\
\text { signature \& Date }\end{array}$} \\
\hline \multicolumn{7}{|c|}{$\begin{array}{l}\text { 13a. Description of change } 13 \mathrm{~b} \text {. Design Baseline Document? [] Yes }[X] \text { No } \\
\text { The document has been totally revised to include the results of recent sampling to } \\
\text { address technical issues associated with the waste, and to update the best basis } \\
\text { standard inventory. }\end{array}$} \\
\hline
\end{tabular}

14a. Justification (mark one)

$\begin{array}{llllllll}\text { Criteria Change } & {[\mathrm{X}]} & \text { Design Improvement } & {[]} & \text { Environmental } & {[]} & \text { Facility Deactivation } & {[]} \\ \text { As-Found } & {[]} & \text { Facilitate Const } & {[]} & \text { Const. Error/Omission } & {[]} & \text { Design Error/Omission } & {[]}\end{array}$

14b. Justification Details

Changes required to incorporate new sampling data.

15. Distribution (include name, MSIN, and no. of copies)

See attached distribution.

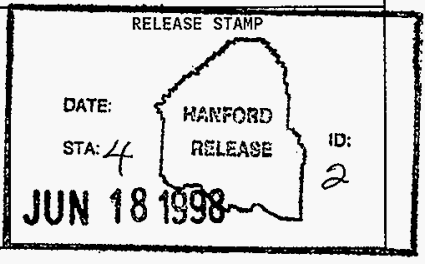

A-7900-013-2 (05/96) GEF095 


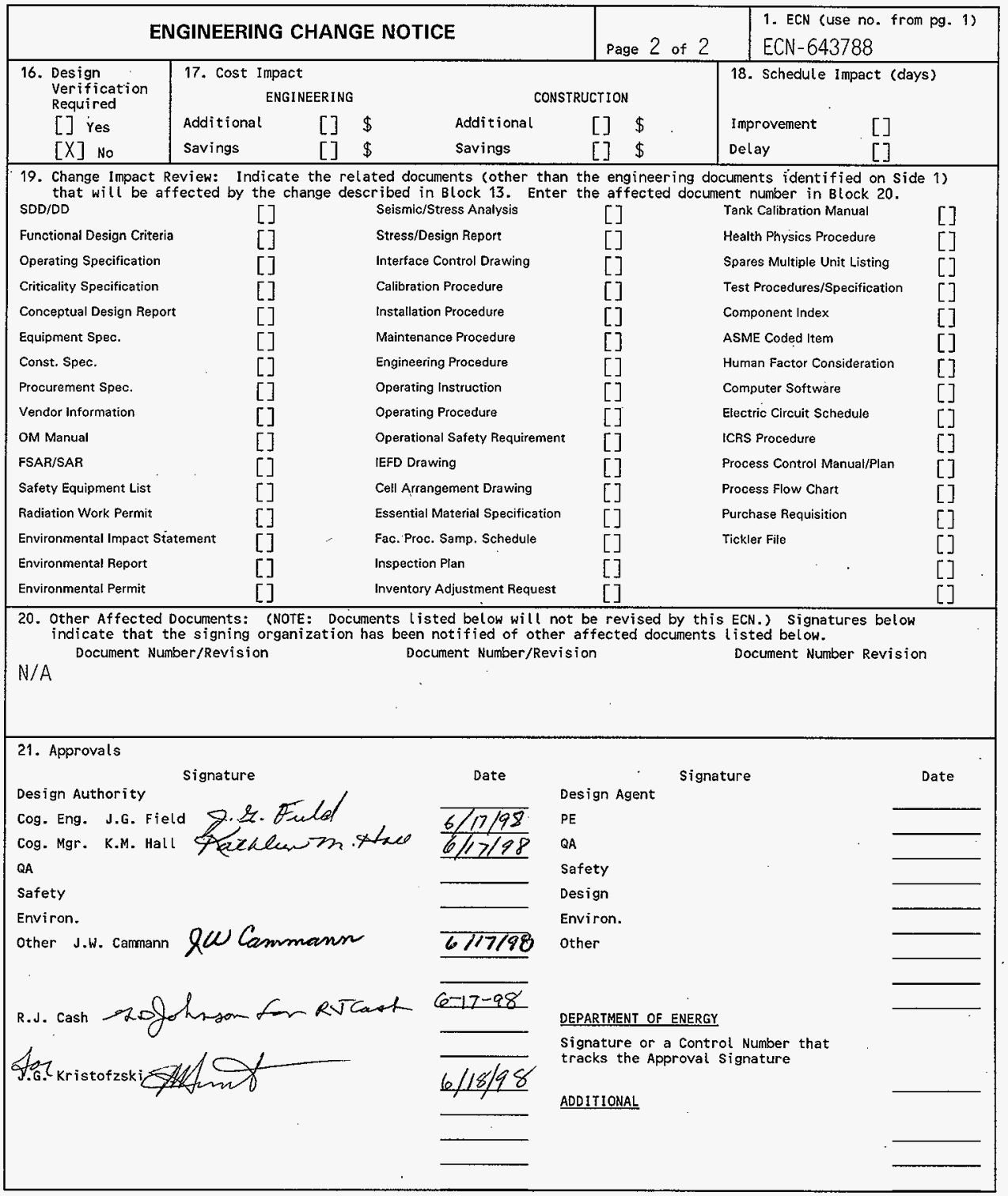




\section{Tank Characterization Report for Single-Shell Tank 241-T-105}

Jim G. Field

Lockheed Martin Hanford Corp., Richiand, WA 99352

U.S. Department of Energy Contract DE-AC06-87RL10930

EDT/ECN : ECN-643788 UC: 2070

Org Code: 74620

B\&R Code: EW 3120074 Total Pages: 199

Key Words: Waste Characterization, Single-Shell Tank, SST, Tank 241-T105. Tank T-105. T-105, T Farm, Tank Characterization Report, TCR, Waste Inventory. TPA Milestone M-44

Abstract: This document summarizes the information on the historical uses, present status, and the sampling and analysis results of waste stored in Tank 241-T-105. This report supports the requirements of the Tri-Party Agreement Mi lestone M-44-15B.

TRADEMARK DISCLAIMER. Reference herein to any specific commercial product, process, or service by trade name, trademark, manufacturer, or otherwise, does not necessarily constitute or imply its endorsement, recommendation, or favoring by the United States Government or any agency thereof or its contractors or subcontractors.

Printed in the United States of America. To obtain copies of this document, contact: WHC/BCS Document Control Services, P.O. Box 1970, Mailstop H6-08, Richland WA 99352, Phone (509) 372-2420; Fax (509) 376-4989.

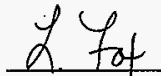

Release Approval
JUN 181998

Date

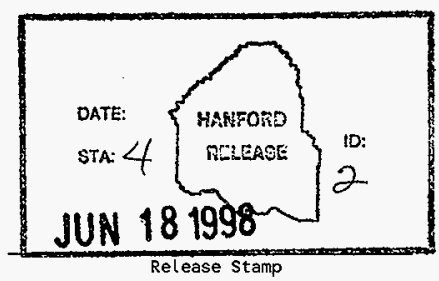


RECORD OF REVISION

(1) Document Muriber

HNF-SD-HM-ER-369

Page 1

(2) Title

Tank Characterization Report for Single-Shel Tank 241-T-105

CHAHSE CONIBOL BEECORO

\begin{tabular}{|c|c|c|c|}
\hline \multirow{2}{*}{ (3) Revision } & \multirow{2}{*}{ (4) Description of Chanse - Replace, Add, and Delete. Pagses } & \multicolumn{2}{|c|}{ Authorized for Belesse } \\
\hline & & (5) Cose. Engr. & (6) Coy, Mgr, Date \\
\hline 0 & (7) Initially released on EDT 159082 & B. C. Simpson & c. S. Haller \\
\hline I RS & Incorporate per ECH 635417 & J. G. Fieild & K. H. HalH/hit \\
\hline & & (1.5) rill 1/20 & (5) \\
\hline & & & \\
\hline $1-\mathrm{A} \quad \mathrm{RS}$ & Incorporate per ECn-1035536. & S.G. Field & K.m. Hall \\
\hline & & 2.4 tresled sholis & 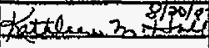 \\
\hline 285 & Incorporate per ECn-643788 & J.G. Field & K.m. Hall \\
\hline & & C. 4 Fretd & Actrenshst \\
\hline & & $7_{6}^{\prime} 17798$ & $6 / 12 / 98$ \\
\hline
\end{tabular}




\title{
Tank Characterization Report for Single-Shell Tank 241-T-105
}

\author{
J. G. Field \\ S: R. Wilmarth \\ Lockheed Martin Hanford Corp. \\ Date Published \\ June 1998
}

Prepared for the U.S. Department of Energy Assistant Secretary for Environmental Management

FUUOR DANIEL MANFORD, INC. Richland, Washington

Hanford Management and Integration Contractor for the

U.S. Department of Energy under Contract DE-AC06-96RL13200 


\section{CONTENTS}

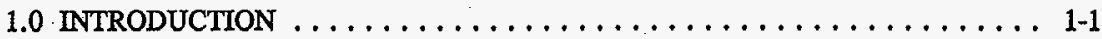

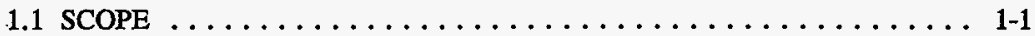

1.2 TANK BACKGROUND $\ldots \ldots \ldots \ldots \ldots \ldots \ldots \ldots \ldots \ldots \ldots 1-2$

2.0 RESPONSE TO TECHNICAL ISSUES $\ldots \ldots \ldots \ldots \ldots \ldots \ldots \ldots \ldots \ldots$ 2-1

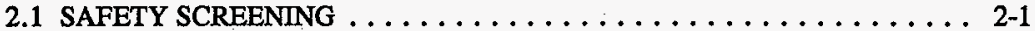

2.1.1 Exothermic Conditions (Energetics) $\ldots \ldots \ldots \ldots \ldots \ldots \ldots \ldots . \ldots \ldots$

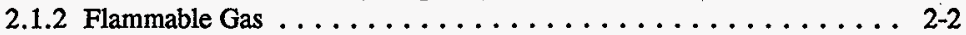

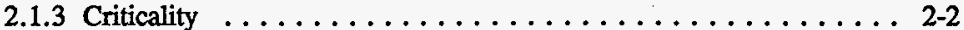

2.2 ORGANIC COMPLEXANTS . . . . . . . . . . . . 2-2

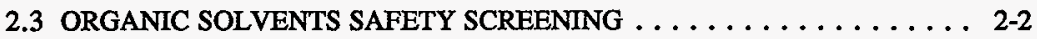

2.4 OTHER TECHNICAL ISSUES $\ldots \ldots \ldots \ldots \ldots \ldots \ldots \ldots \ldots \ldots . \ldots \ldots$

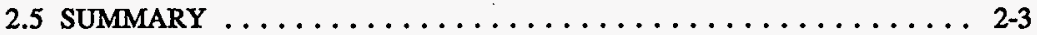

3.0 BEST-BASIS INVENTORY ESTIMATE $\ldots \ldots \ldots \ldots \ldots \ldots \ldots \ldots$ 3-1

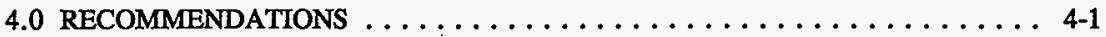

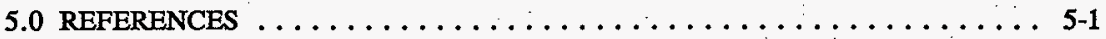

APPENDICES

APPENDIX A: HISTORICAL TANK INFORMATION $\ldots \ldots \ldots \ldots \ldots \ldots$ A-1

A1.0 CURRENT TANK STATUS $\ldots \ldots \ldots \ldots \ldots \ldots \ldots \ldots \ldots \ldots \ldots$ A-3

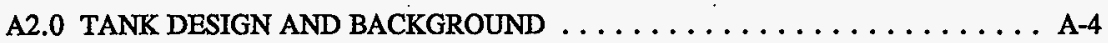

A3.0 PROCESS KNOWLEDGE . . . . . . . . . . . . . . . . . . A-9

A3.1 WASTE TRANSFER HISTORY . . . . . . . . . . . A-9

A3.2 HISTORICAL ESTIMATION OF TANK CONTENTS . . . . . . . A A-11

A4.0 SURVEILLANCE DATA $\ldots \ldots \ldots \ldots \ldots \ldots \ldots \ldots \ldots \ldots \ldots$ A-16

A4.1 SURFACE-LEVEL READINGS $\ldots \ldots \ldots \ldots \ldots \ldots \ldots \ldots$ A-16

A4.2 INTERNAL TANK TEMPERATURES $\ldots \ldots \ldots \ldots \ldots \ldots \ldots$ A-17

A4.3 DRY WELL RADIOACTIVITY . . . . . . . . . . . A-17

A4.4 TANK 241-T-105 PHOTOGRAPHS . . . . . . . . . . . . . A A-17

A5.0 APPENDIX A REFERENCES $\ldots \ldots \ldots \ldots \ldots \ldots \ldots \ldots \ldots \ldots \ldots$ A-20 


\section{CONTENTS (Continued)}

APPENDIX B: SAMPLING OF TANK $241-T-105 \ldots \ldots \ldots \ldots \ldots \ldots$ B-1

B1:0 TANK SAMPLING OVERVIEW $\ldots \ldots \ldots \ldots \ldots \ldots \ldots \ldots \ldots$ B-3

B2.0 SAMPLING EVENTS $\ldots \ldots \ldots \ldots \ldots \ldots \ldots \ldots \ldots \ldots \ldots$ B-4

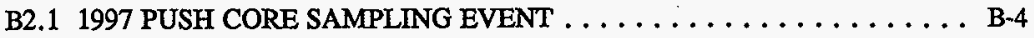

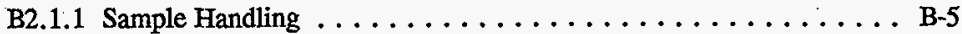

B2.1.2 Sample Analysis $\ldots \ldots \ldots \ldots \ldots \ldots \ldots \ldots \ldots \ldots \ldots$

B2.1.3 Analytical Results $\ldots \ldots \ldots \ldots \ldots \ldots \ldots \ldots \ldots$ B-10

B2.2 1993 PUSH CORE SAMPLING EVENT $\ldots \ldots \ldots \ldots \ldots \ldots \ldots \ldots$ B-12

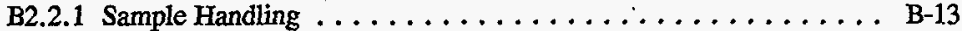

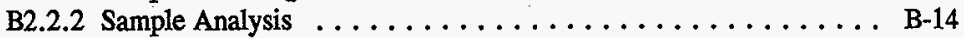

B2.2.3 Analytical Results $\ldots \ldots \ldots \ldots \ldots \ldots \ldots \ldots \ldots \ldots \ldots \ldots$

B2.3 VAPOR PHASE MEASUREMENT $\ldots \ldots \ldots \ldots \ldots \ldots \ldots \ldots \ldots$ B-24

B2.4 HISTORICAL SAMPLE RESULTS $\ldots \ldots \ldots \ldots \ldots \ldots \ldots \ldots \ldots$. . . . . . .

B3.0 ASSESSMENT OF CHARACTERIZATION RESULTS $\ldots \ldots \ldots \ldots \ldots \ldots$. . . B-85

B3.1 FIELD OBSERVATIONS $\ldots \ldots \ldots \ldots \ldots \ldots \ldots \ldots \ldots \ldots$ B-85

B3.2 QUALITY CONTROL ASSESSMENT $\ldots \ldots \ldots \ldots \ldots \ldots \ldots \ldots$ B-85

B3.3 DATA CONSISTENCY CHECKS . . . . . . . . . . . B B-86

B3.3.1 Comparison of Results from Different Analytical Methods . . . . . B B-86

B3.3.2 Mass and Charge Balances . . . . . . . . . . . . . B-87

B3.4 MEANS AND CONFIDENCE INTERVALS $\ldots \ldots \ldots \ldots \ldots \ldots \ldots \ldots$. . . . . . .

B3.4.1 Solid Data $\ldots \ldots \ldots \ldots \ldots \ldots \ldots \ldots \ldots \ldots \ldots \ldots$ B-91

B3.4.2 Liquid Data $\ldots \ldots \ldots \ldots \ldots \ldots \ldots \ldots \ldots \ldots \ldots$ B-94

B4.0 APPENDIX B REFERENCES $\ldots \ldots \ldots \ldots \ldots \ldots \ldots \ldots \ldots \ldots$ B-96

APPENDIX C: STATISTICAL ANALYSIS FOR ISSUE RESOLUTION $\ldots \ldots \ldots \ldots$ C-1

C1.0 STATISTICS FOR THE SAFETY SCREENING

DATA QUALTTY OBJECTIVE . . . . . . . . . . . . . C-3

C2.0 APPENDIX C REFERENCES $\ldots \ldots \ldots \ldots \ldots \ldots \ldots \ldots \ldots \ldots \ldots$ C-4 
CONTENTS (Continued)

APPENDIX D: EVALUATION TO ESTABLISH BEST-BASIS INVENTORY FOR

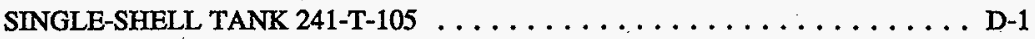

D1.0 CHEMICAL INFORMATION SOURCES $\ldots \ldots \ldots \ldots \ldots \ldots \ldots$ D-3

D2.0 COMPARISON OF COMPONENT INVENTORY VALUES $\ldots \ldots \ldots \ldots \ldots$ D-3

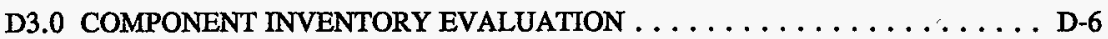

D3.1 WASTE HISTORY OF TANK $241-\mathrm{T}-105 \ldots \ldots \ldots \ldots \ldots \ldots \ldots$ D-6

D3.2 CONTRIBUTING WASTE TYPES $\ldots \ldots \ldots \ldots \ldots \ldots \ldots \ldots \ldots$ D-7

D3.3 ASSUMPTIONS USED $\ldots \ldots \ldots \ldots \ldots \ldots \ldots \ldots \ldots \ldots \ldots \ldots$ D-7

D3.4 METHODOLOGY FOR ESTIMATING TANK 241-T-105 INVENTORY . D-8

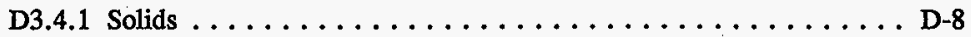

D3.4.2 Liquids . . . . . . . . . . . . . . . . D-10

D3.5 ESTIMATED INVENTORY OF COMPONENTS . . . . . . . D-12

D4.0 DEFINE THE BEST-BASIS AND ESTABLISH

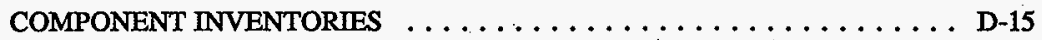

D5.0 APPENDIX D REFERENCES $\ldots \ldots \ldots \ldots \ldots \ldots \ldots \ldots \ldots \ldots \ldots$ D-20

APPENDIX E: BIBLIOGRAPHY FOR TANK $241-T-105 \ldots \ldots \ldots \ldots \ldots \ldots$ E-1

\section{LIST OF FIGURES}

A2-1 Riser Configuration for Tank $241-T-105 \ldots \ldots \ldots \ldots \ldots \ldots \ldots$ A-6

A2-2 Tank 241-T-105 Cross Section and Schematic . . . . . . . . . A-8

A3-1 Tank Layer Model. . . . . . . . . . . . . . . . A A-12

A4-1 Tank 241-T-105 Level History $\ldots \ldots \ldots \ldots \ldots \ldots \ldots \ldots \ldots \ldots$ A-18

A4-2 Tank 241-T-105 High Temperature Plot $\ldots \ldots \ldots \ldots \ldots \ldots \ldots$ A-19 


\section{LIST OF TABLES}

1-1 Summary of Recent Sampling $\ldots \ldots \ldots \ldots \ldots \ldots \ldots \ldots \ldots \ldots \ldots$

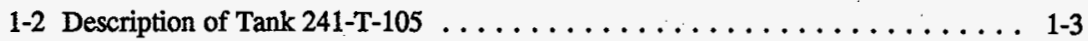

2-1 Tank 241-T-105 Projected Heat Load . . . . . . . . . . . . . 2-3

2-2 Summary of Technical Issues $\ldots \ldots \ldots \ldots \ldots \ldots \ldots \ldots \ldots \ldots \ldots \ldots \ldots . \ldots \ldots$

3-1 Best-Basis Inventory Estimates for Nonradioactive Components

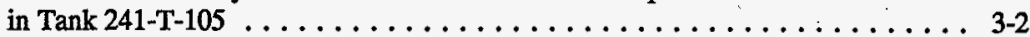

3-2 Best-Basis Inventory Estimates for Radioactive Components in Tank 241-T-105 Decayed to January $1,1994 \ldots \ldots \ldots \ldots \ldots \ldots \ldots \ldots \ldots \ldots \ldots$. $3 . \ldots \ldots$

4-1 Acceptance of Tank 241-T-105 Sampling and Analysis . . . . . . . . . 4-1

4-2 Acceptance of Evaluation of Characterization Data and Information for Tank $241-\mathrm{T}-105 \ldots \ldots \ldots \ldots \ldots \ldots \ldots \ldots \ldots \ldots \ldots \ldots$. . . . . . . . . . .

A1-1 Tank 241-T-105 Contents Status Summary . . . . . . . . . . A-4

A2-1 Tank $241-\mathrm{T}-105$ Risers $\ldots \ldots \ldots \ldots \ldots \ldots \ldots \ldots \ldots \ldots \ldots$ A-7

A3-1 Tank 241-T-105 Major Transfers . . . . . . . . . . . . . A-10

A3-2 Historical Tank Inventory Estimate $\ldots \ldots \ldots \ldots \ldots \ldots \ldots \ldots \ldots$ A-13

B2-1 Integrated Data Quality Objective Requirements for Tank 241-T-105 . . . . . . B-4

B2-2 Tank 241-T-105 Subsampling Scheme and Sample Description . . . . . . . B-6

B2-3 Analytical Procedures $\ldots \ldots \ldots \ldots \ldots \ldots \ldots \ldots \ldots \ldots \ldots \ldots \ldots$ B-7

B2-4 Sample Analyses Summary $\ldots \ldots \ldots \ldots \ldots \ldots \ldots \ldots \ldots \ldots$ B-8

B2-5 Analytical Tables $\ldots \ldots \ldots \ldots \ldots \ldots \ldots \ldots \ldots \ldots \ldots \ldots \ldots$ B-10

B2-6 Tank 241-T-105 Subsampling Scheme and Sample Description . . . . . . . B B-13

B2-7 Analyses Performed on the Solids (by Segment) $\ldots \ldots \ldots \ldots \ldots \ldots$ B-15 


\section{LIST OF TABLES (Continued)}

B2-8 Analyses Performed on the Drainable Liquid (by Segment) $\ldots \ldots \ldots \ldots$. . . B-17

B2-9 Inorganic and Radiochemical Analytical Methods $\ldots \ldots \ldots \ldots \ldots \ldots$ B-17

B2-10 Physical and Rheological Analytical Methods $\ldots \ldots \ldots \ldots \ldots \ldots \ldots$ B-18

B2-11 Analytical Data Presentation Tables $\ldots \ldots \ldots \ldots \ldots \ldots \ldots \ldots$ B-19

B2-12 Tank 241-T-105 Analytical Results: Aluminum (ICP) . . . . . . . . . . B-25

B2-13 Tank 241-T-105 Analytical Results: Antimony (ICP) $\ldots \ldots \ldots \ldots \ldots \ldots$ B-25

B2-14 Tank 241-T-105 Analytical Results: Arsenic (ICP) $\ldots \ldots \ldots \ldots \ldots \ldots$ B-26

B2-15 Tank 241-T-105 Analytical Results: Barium (ICP) $\ldots \ldots \ldots \ldots \ldots \ldots \ldots$ B-26

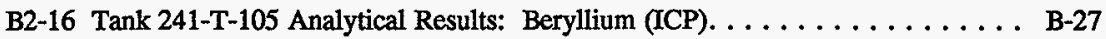

B2-17 Tank 241-T-105 Analytical Results: Bismuth (ICP) . . . . . . . . . . . B-27

B2-18 Tank 241-T-105 Analytical Results: Boron (ICP) $\ldots \ldots \ldots \ldots \ldots \ldots$ B-28

B2-19 Tank 241-T-105 Analytical Results: Cadmium (ICP) $\ldots \ldots \ldots \ldots \ldots \ldots$ B-28

B2-20 Tank 241-T-105 Analytical Results: Calcium (ICP) $\ldots \ldots \ldots \ldots \ldots \ldots$. . . . . . . .

B2-21 Tank 241-T-105 Analytical Results: Cerium (ICP) . . . . . . . . . . . . B-29

B2-22 Tank 241-T-105 Analytical Results: Chromium (ICP) . . . . . . . . . . B-30

B2-23 Tank 241-T-105 Analytical Results: Cobalt (ICP). . . . . . . . . . B B-30

B2-24 Tank 241-T-105 Analytical Results: Copper (ICP) . . . . . . . . . B B-31

B2-25 Tank 241-T-105 Analytical Results: Iron (ICP) $\ldots \ldots \ldots \ldots \ldots \ldots \ldots$ B-31

B2-26 Tank 241-T-105 Analytical Results: Lanthanum (ICP) $\ldots \ldots \ldots \ldots \ldots$. . . .32

B2-27 Tank 241-T-105 Analytical Results: Lead (ICP) . . . . . . . . . . . B-32 


\section{LIST OF TABLES (Continued)}

B2-28 Tank 241-T-105 Analytical Results: Lithium (ICP). . . . . . . . . . B-33

B2-29 Tank 241-T-105 Analytical Results: Magnesium (ICP) . . . . . . . . . B-33

B2-30 Tank 241-T-105 Analytical Results: Manganese (ICP) $\ldots \ldots \ldots \ldots \ldots \ldots$ B-34

B2-31 Tank 241-T-105 Analytical Results: Molybdenum (ICP) . . . . . . . . . . . B-34

B2-32 Tank 241-T-105 Analytical Results: Neodymium (ICP) . . . . . . . B B-35

B2-33 Tank 241-T-105 Analytical Results: Nickel (ICP) . . . . . . . . . . B-35

B2-34 Tank 241-T-105 Analytical Results: Phosphorus (ICP) . . . . . . . . . B-36

B2-35 Tank 241-T-105 Analytical Results: Potassium (ICP) $\ldots \ldots \ldots \ldots \ldots$. . . . . .

B2-36 Tank 241-T-105 Analytical Results: Samarium (ICP) . . . . . . . . . B-37

B2-37. Tank 241-T-105 Analytical Results: Selenium (ICP) $\ldots \ldots \ldots \ldots \ldots$. . . . .

B2-38 Tank 241-T-105 Analytical Results: Silicon (ICP) $\ldots \ldots \ldots \ldots \ldots \ldots$ B-38

B2-39 Tank 241-T-105 Analytical Results: Silver (ICP) . . . . . . . . . . B B-38

B2-40 Tank 241-T-105 Analytical Results: Sodium (ICP) . . . . . . . . . . . . B B-39

B2-41 Tank 241-T-105 Analytical Results: Strontium (ICP) . . . . . . . . . . B-39

B2-42 Tank 241-T-105 Analytical Results: Sulfur (ICP) $\ldots \ldots \ldots \ldots \ldots \ldots$ B-40

B2-43 Tank 241-T-105 Analytical Results: Thallium (ICP) . . . . . . . . . B-40

B2-44 Tank 241-T-105 Analytical Results: Titanium (ICP) . . . . . . . . . . . . B-41

B2-45 Tank 241-T-105 Analytical Results: Total Uranium (ICP) . . . . . . . . B-41

B2-46 Tank 241-T-105 Analytical Results: Vanadium (ICP) $\ldots \ldots \ldots \ldots \ldots$ B-42

B2-47 Tank 241-T-105 Analytical Results: Zinc (ICP) $\ldots \ldots \ldots \ldots \ldots$. . . . .

B2-48 Tank 241-T-105 Analytical Results: Zirconium (ICP) . . . . . . . . B B-43 


\section{LIST OF TABLES (Continued)}

B2-49 Tank 241-T-105 Analytical Results: Bromide (IC). . . . . . . . . . B-43

B2-50 Tank 241-T-105 Analytical Results: Chloride (IC) . . . . . . . . . . . B B-44

B2-51 Tank 241-T-105 Analytical Results: Fluoride (IC) $\ldots \ldots \ldots \ldots \ldots \ldots$ B-44

B2-52 Tank 241-T-105 Analytical Results: Nitrate (IC) $\ldots \ldots \ldots \ldots \ldots \ldots$ B-45

B2-53 Tank 241-T-105 Analytical Results: Nitrite (IC) $\ldots \ldots \ldots \ldots \ldots \ldots$ B-45

B2-54 Tank 241-T-105 Analytical Results: Phosphate (IC) . . . . . . . . . . . B-46

B2-55 Tank 241-T-105 Analytical Results: Sulfate (IC) $\ldots \ldots \ldots \ldots \ldots \ldots$ B-46

B2-56 Tank 241-T-105 Analytical Results: Oxalate (IC) $\ldots \ldots \ldots \ldots \ldots \ldots$ B-47

B2-57 Tank 241-T-105 Analytical Results: Bulk Density. . . . . . . . . . B B-47

B2-58 Tank 241-T-105 Analytical Results: Percent Water (TGA) . . . . . . . . B-48

B2-59 Tank 241-T-105 Analytical Results: Specific Gravity . . . . . . . . . B-48

B2-60 Tank 241-T-105 Analytical Results: Total Alpha . . . . . . . . . . B-48

B2-61 Tank 241-T-105 Analytical Results: Cesium (Atomic Absorption) . . . . . . . B-49

B2-62 Tank 241-T-105 Analytical Results: Mercury (Cold Vapor Atomic Absorption) B-49

B2-63 Tank 241-T-105 Analytical Results: Aluminum (ICP) . . . . . . . . B-50

B2-64 Tank 241-T-105 Analytical Results: Antimony (ICP) $\ldots \ldots \ldots \ldots \ldots \ldots$ B-50

B2-65 Tank 241-T-105 Analytical Results: Arsenic (ICP) $\ldots \ldots \ldots \ldots \ldots \ldots$ B-51

B2-66 Tank 241-T-105 Analytical Results: Beryllium (ICP) $\ldots \ldots \ldots \ldots \ldots \ldots$ B-51

B2-67 Tank 241-T-105 Analytical Results: Bismuth (ICP) $\ldots \ldots \ldots \ldots \ldots \ldots$ B-52

B2-68 Tank 241-T-105 Analytical Results: Boron (ICP) $\ldots \ldots \ldots \ldots \ldots \ldots$ B-52

B2-69 Tank 241-T-105 Analytical Results: Cadmium (ICP) $\ldots \ldots \ldots \ldots \ldots \ldots$ B-53 


\section{LIST OF TABLES (Continued)}

B2-70 Tank 241-T-105 Analytical Results: Calcium (ICP) $\ldots \ldots \ldots \ldots \ldots \ldots$ B-53

B2-71 Tank 241-T-105 Analytical Results: Cerium (ICP) . . . . . . . . . . . B-54

B2-72 Tank 241-T-105 Analytical Results: Chromium (ICP) . . . . . . . . . . B B-54

B2-73 Tank 241-T-105 Analytical Results: Iron (ICP) $\ldots \ldots \ldots \ldots \ldots \ldots \ldots$ B-55

B2-74 Tank 241-T-105 Analytical Results: Lanthanum (ICP) $\ldots \ldots \ldots \ldots \ldots$ B-55

B2-75 Tank 241-T-105 Analytical Results: Lead (ICP) $\ldots \ldots \ldots \ldots \ldots \ldots$ B-56

B2-76 Tank 241-T-105 Analytical Results: Lithium (ICP) $\ldots \ldots \ldots \ldots \ldots \ldots$. . . . . .

B2-77 Tank 241-T-105 Analytical Results: Magnesium (ICP) . . . . . . . . . . B-57

B2-78 Tank 241-T-105 Analytical Results: Manganese (ICP) $\ldots \ldots \ldots \ldots \ldots$ B-57

B2-79 Tank 241-T-105 Analytical Results: Molybdenum (ICP) . . . . . . . . . . . B-58

B2-80 Tank 241-T-105 Analytical Results: Neodymium (ICP) $\ldots \ldots \ldots \ldots \ldots$ B-58

B2-81 Tank 241-T-105 Analytical Results: Nickel (ICP) . . . . . . . . . . . B-59

B2-82 Tank 241-T-105 Analytical Results: Phosphorus (ICP) $\ldots \ldots \ldots \ldots \ldots \ldots$. . . . . .

B2-83 Tank 241-T-105 Analytical Results: Potassium (ICP) $\ldots \ldots \ldots \ldots \ldots$. . B-60

B2-84 Tank 241-T-105 Analytical Results: Samarium (ICP) $\ldots \ldots \ldots \ldots \ldots \ldots$. . . . . . .

B2-85 Tank 241-T-105 Analytical Results: Selenium (ICP) $\ldots \ldots \ldots \ldots \ldots \ldots$ B-61

B2-86 Tank 241-T-105 Analytical Results: Silicon (ICP) . . . . . . . . . . . B-61

B2-87 Tank 241-T-105 Analytical Results: Silver (ICP) . . . . . . . . . . B-62

B2-88 Tank 241-T-105 Analytical Results: Sodium (ICP) $\ldots \ldots \ldots \ldots \ldots \ldots$ B-62

B2-89 Tank 241-T-105 Analytical Results: Strontium (ICP) $\ldots \ldots \ldots \ldots \ldots \ldots$ B-63

B2-90 Tank 241-T-105 Analytical Results: Sulfur (ICP) $\ldots \ldots \ldots \ldots \ldots \ldots$ B-63 


\section{LIST OF TABLES (Continued)}

B2-91 Tank 241-T-105 Analytical Results: Thallium (ICP) . . . . . . . . . . . . B-64

B2-92 Tank 241-T-105 Analytical Results: Titanium (ICP) $\ldots \ldots \ldots \ldots \ldots \ldots$ B-64

B2-93 Tank 241-T-105 Analytical Results: Zirconium (ICP) $\ldots \ldots \ldots \ldots \ldots$ B-65

B2-94 Tank 241-T-105 Analytical Results: Total Uranium (Laser Fluorimetry) . . . B B-65

B2-95 Tank 241-T-105 Analytical Results: Hexavalent Chromium $(\mathrm{Cr}+6) \ldots \ldots$. . B-65

B2-96 Tank 241-T-105 Analytical Results: Ammonia (Distillation) . . . . . . . . B-66

B2-97 Tank 241-T-105 Analytical Results: pH Measurement . . . . . . . . . . B-66

B2-98 Tank 241-T-105 Analytical Results: Chloride (IC) $\ldots \ldots \ldots \ldots \ldots \ldots$. . .66

B2-99 Tank 241-T-105 Analytical Results: Fluoride (IC) $\ldots \ldots \ldots \ldots \ldots \ldots$ B-67

B2-100 Tank 241-T-105 Analytical Results: Nitrate (IC) $\ldots \ldots \ldots \ldots \ldots \ldots \ldots$ B-67

B2-101 Tank 241-T-105 Analytical Results: Nitrite (IC) $\ldots \ldots \ldots \ldots \ldots \ldots$. . . . . .

B2-102 Tank 241-T-105 Analytical Results: Phosphate (IC) $\ldots \ldots \ldots \ldots \ldots \ldots$ B-68

B2-103 Tank 241-T-105 Analytical Results: Sulfate (IC) $\ldots \ldots \ldots \ldots \ldots \ldots$ B-68

B2-104 Tank 241-T-105 Analytical Results: Hydroxide (Titration) . . . . . . . . B B-68

B2-105 Tank 241-T-105 Analytical Results: Cyanide (Distillation/Spectrometry) . . . B-69

B2-106 Tank 241-T-105 Analytical Results: Nitrite (Spectrophotometry) . . . . . . . B-69

B2-107 Tank 241-T-105 Analytical Results: Total Organic Carbon (Furnace Oxidation) $\ldots \ldots \ldots \ldots \ldots \ldots \ldots \ldots \ldots \ldots \ldots \ldots$ B-69

B2-108 Tank 241-T-105 Analytical Results: Total Organic Carbon (Persulfate Oxidation) $\ldots \ldots \ldots \ldots \ldots \ldots \ldots \ldots \ldots \ldots \ldots \ldots \ldots \ldots$ B-70

B2-109 Tank 241-T-105 Analytical Results: Total Inorganic Carbon (Persulfate Oxidation) $\ldots \ldots \ldots \ldots \ldots \ldots \ldots \ldots \ldots \ldots \ldots \ldots$ 


\section{LIST OF TABLES (Continued)}

B2-110 Tank 241-T-105 Analytical Results: Total Inorganic Carbon . . . . . . . . . B-70

B2-111 Tank 241-T-105 Analytical Results: Plutonium-238 to Plutonium Ratio (Mass Spectrometry) . . . . . . . . . . . . . . . B-70

B2-112 Tank 241-T-105 Analytical Results: Plutonium-239 to Plutonium Ratio (Mass Spectrometry) . . . . . . . . . . . . . . . . B-71

B2-113 Tank 241-T-105 Analytical Results: Plutonium-240 to Plutonium Ratio (Mass Spectrometry) $\ldots \ldots \ldots \ldots \ldots \ldots \ldots \ldots \ldots \ldots \ldots$ B-71

B2-114 Tank 241-T-105 Analytical Results: Plutonium-241 to Plutonium Ratio (Mass Spectrometry) $\ldots \ldots \ldots \ldots \ldots \ldots \ldots \ldots \ldots \ldots \ldots$ B-71

B2-115 Tank 241-T-105 Analytical Results: Plutonium-242 to Plutonium Ratio (Mass Spectrometry) $\ldots \ldots \ldots \ldots \ldots \ldots \ldots \ldots \ldots \ldots \ldots$ B-71

B2-116 Tank 241-T-105 Analytical Results: Uranium-234 to Uranium Ratio (Mass Spectrometry) . . . . . . . . . . . . . . . B-71

B2-117 Tank 241-T-105 Analytical Results: Uranium-235 to Uranium Ratio (Mass Spectrometry) . . . . . . . . . . . . . . .

B2-118 Tank 241-T-105 Analytical Results: Uranium-236 to Uranium Ratio

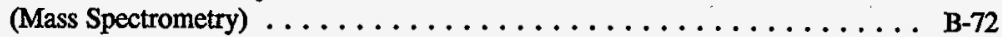

B2-119 Tank 241-T-105 Analytical Results: Uranium-238 to Uranium Ratio

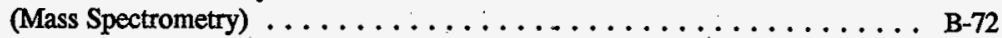

B2-120 Tank 241-T-105 Analytical Results: Total Alpha . . . . . . . . . . . B-72

B2-121 Tank 241-T-105 Analytical Results: Total Alpha $\mathrm{Pu} \ldots \ldots \ldots \ldots \ldots$. . . . B-73

B2-122 Tank 241-T-105 Analytical Results: Americium-241 (Alpha Spectrometry) . B-73

B2-123 Tank 241-T-105 Analytical Results: Plutonium-238 (Alpha Spectrometry) . . B B-73

B2-124 Tank 241-T-105 Analytical Results: Plutonium-239/40 (Alpha Spectrometry) . B-73

B2-125 Tank 241-T-105 Analytical Results: Total Beta (Beta Proportional Counting) . B-74 


\section{LIST OF TABLES (Continued)}

B2-126 Tank 241-T-105 Analytical Results: Strontium-90 (Beta Proportional Counting) $\ldots \ldots \ldots \ldots \ldots \ldots \ldots \ldots \ldots \ldots \ldots \ldots$ B-74

B2-127 Tank 241-T-105 Analytical Results: Americium-241 (GEA) . . . . . . . . B-74

B2-128 Tank 241-T-105 Analytical Results: Antimony-125 (GEA) . . . . . . . . . B-75

B2-129 Tank 241-T-105 Analytical Results: Cerium/Praseodymium-144 (GEA) . . . B-75

B2-130 Tank 241-T-105 Analytical Results: Cesium-134 (GEA) . . . . . . . . . B-75

B2-131 Tank 241-T-105 Analytical Results: Cesium-137 (GEA) $\ldots \ldots \ldots \ldots \ldots$ B-76

B2-132 Tank 241-T-105 Analytical Results: Cobalt-60 (GEA) . . . . . . . . . B-76

B2-133 Tank 241-T-105 Analytical Results: Europium-154 (GEA) . . . . . . . . B B-77

B2-134 Tank 241-T-105 Analytical Results: Europium-155 (GEA) . . . . . . . . . B-77

B2-135 Tank 241-T-105 Analytical Results: Potassium-40 (GEA) . . . . . . . B-78

B2-136 Tank 241-T-105 Analytical Results: Ruthenium-103 (GEA) . . . . . . . B B-78

B2-137 Tank 241-T-105 Analytical Results: Ruthenium/Rhodium-106 (GEA) . . . . B B-79

B2-138 Tank 241-T-105 Analytical Results: Thorium-228 (GEA) . . . . . . . . B-79

B2-139 Tank 241-T-105 Analytical Results: Carbon-14 (Liquid Scintillation) . . . . B B-80

B2-140 Tank 241-T-105 Analytical Results: Tritium (Liquid Scintillation) . . . . . . B-80

B2-141 Tank 241-T-105 Analytical Results: Technetium-99 (Liquid Scintillation) . . B-80

B2-142 Tank 241-T-105 Analytical Results: Weight Percent Solids (Percent Solids) . B B-80

B2-143 Tank 241-T-105 Analytical Results: Weight Percent Centrifuged Solids (Physical Properties) . . . . . . . . . . . . . . . B-81

B2-144 Tank 241-T-105 Analytical Results: Weight Percent Residual Solids (Percent Solids) $\ldots \ldots \ldots \ldots \ldots \ldots \ldots \ldots \ldots \ldots \ldots \ldots \ldots \ldots \ldots \ldots$ 


\section{LIST OF TABLES (Continued)}

B2-145 Tank 241-T-105 Analytical Results: Density (Physical Properties) . . . . . . B-81

B2-146 Tank 241-T-105 Analytical Results: Density of Solids Centrifuged from Supernatant (Physical Properties) . . . . . . . . . . . . . B-82

B2-147 Tank 241-T-105 Analytical Results: Centrifuged Solids Density (Physical Properties) $\ldots \ldots \ldots \ldots \ldots \ldots \ldots \ldots \ldots \ldots \ldots \ldots \ldots$ B-82

B2-148 Tank 241-T-105 Analytical Results: Specific Gravity . . . . . . . . B-82

B2-149 Tank 241-T-105 Analytical Results: Volume Percent Settled Solids (Physical Properties) . . . . . . . . . . . . . . . B

B2-150 Tank 241-T-105 Analytical Results: Volume Percent Centrifuged Solids (Physical Properties) ...................... B-83

B2-151 Tank 241-T-105 Analytical Results: Total Dișsolved Solids (Percent Solids) . . B-83 B2-152 Tank 241-T-105 Analytical Results: Consistency Factor (Physical Properties) . B-83 B2-153 Tank 241-T-105 Analytical Results: Flow Behavior Index (Physical Properties) . . . . . . . . . . . . . . . $\ldots$ B-83

B2-154 Tank 241-T-105 Analytical Results: Yield Point (Physical Properties) . . . . . B-84

B2-155 Tank 241-T-105 Analytical Results: Exothermic Results (DSC) . . . . . . . . B-84 B2-156 Tank 241-T-105 Analytical Results: Percent Water (TGA) . . . . . . . . B B-84

B3-1 Solids Cation Mass and Charge Data. . . . . . . . . . . . B-88

B3-2 Solids Anion Mass and Charge Data $\ldots \ldots \ldots \ldots \ldots \ldots \ldots$ B-88

B3-3 Solids Mass Balance Totals . . . . . . . . . . . . . . . B-88

B3-4 Liquid Cations Mass and Charge Data. . . . . . . . . . . B-90

B3-5 Liquid Anions Mass and Charge Data $\ldots \ldots \ldots \ldots \ldots \ldots \ldots$ B-90

B3-6 Liquids Mass Balance Totals . . . . . . . . . . . . . . B-90 


\section{LIST OF TABLES (Continued)}

B3-7 95 Percent Two-Sided Confidence Interval for the Mean Concentration for Solid Segment Data $\ldots \ldots \ldots \ldots \ldots \ldots \ldots \ldots \ldots \ldots \ldots \ldots$ B-92

B3-8 95 Percent Two-Sided Confidence Interval for the Mean Concentration for Liquid Data $\ldots \ldots \ldots \ldots \ldots \ldots \ldots \ldots \ldots \ldots \ldots$ B $\ldots \ldots 5$

C1-1 95 Percent Upper Confidence Limits for Gross Alpha . . . . . . . . . . . C-4

D2-1 Previous Best Basis and Historical Tank Content Inventory Estimates for Nonradioactive Components in Tank 241-T-105 . . . . . . . . . . D-4

D2-2 Previous Best Basis and Historical Tank Content Inventory Estimates for Radioactive Components in Tank 241-T-105 . . . . . . . . . D-5

D3-1 Solids Composition for R1, CWR1, and 1C Waste Types, and Predictions for the Composition of Tank $241-\mathrm{T}-105$ Solids. . . . . . . . . . . . . D-8

D3-2 Liquid Composition for Tank 241-T-105. . . . . . . . . . D-10

D3-3 Estimated Inventory for Tank $241-T-105 \ldots \ldots \ldots \ldots \ldots \ldots \ldots$ D-12

D4-1 Best-Basis Inventory Estimates for Nonradioactive Components in Tank 241-T-105 ......................... D-17

D4-2 Best-Basis Inventory Estimates for Radioactive Components in Tank 241-U-112.

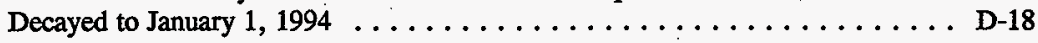




\section{LIST OF TERMS}

$1 \mathrm{C}$

1C2

$2 \mathrm{C}$

2C1

AES

ASTM

BL

Btu/hr

Ci

$\mathrm{Ci} / \mathrm{L}$

CI

$\mathrm{cm}$

$\mathrm{c} / \mathrm{s}$

CW

DQO

DSC

$\mathrm{ft}$

g

$\mathrm{g} / \mathrm{cm}^{3}$.

$\mathrm{g} / \mathrm{L}$

$\mathrm{g} / \mathrm{mL}$

GEA

HDW

HTCE

IC

ICP

in.

IX

$\mathrm{J} / \mathrm{g}$

$\mathrm{kg}$

$\mathrm{kg} / \mathrm{L}$

kgal

kL

$\mathbf{k W}$

LFL

LL first cycle decontamination waste

1C waste produced from 1950 to 1956

second cycle decontamination waste

2C waste produced from 1944 to 1949

atomic emission spectroscopy

American Society for Testing and Materials

B Plant low-level waste

British thermal units per hour

curie

curies per liter

confidence interval

centimeter

counts per second

$\mathrm{BiPO}_{4}$ process aluminum cladding waste

data quality objective

differential scanning calorimetry

feet

gram

grams per cubic centimeter

grams per liter

grams per milliliter

gamma energy analysis

Hanford defined waste

historical tank content estimate

ion chromatography

inductively coupled plasma spectroscopy

inch

ion exchange waste

joules per gram

kilogram

kilograms per liter

kilogallon

kiloliter

kilowatt

lower flammability limit

lower limit 


\section{LIST OF TERMS (Continued)}

$\begin{array}{ll}\mathrm{m} & \text { meter } \\ M & \text { molarity } \\ M / \mathrm{L} & \text { moles per liter } \\ \mathrm{mL} & \text { milliliter } \\ \mathrm{mm} & \text { millimeter } \\ \mathrm{n} / \mathrm{a} & \text { not applicable } \\ \mathrm{NR} & \text { not reported } \\ \mathrm{PHMC} & \text { Project Hanford Management Contractor } \\ \mathrm{ppm} & \text { parts per million } \\ \mathrm{ppmv} & \text { parts per million by volume } \\ \mathrm{QC} & \text { quality control } \\ \mathrm{R} & \text { REDOX (reduction oxidation) } \\ \mathrm{RPD} & \text { relative percent difference } \\ \mathrm{SAP} & \text { sampling and analysis plan } \\ \mathrm{SMM} & \text { supernatant mixing model } \\ \mathrm{SpG} & \text { specific gravity } \\ \mathrm{TCR} & \text { tank characterization report } \\ \mathrm{TGA} & \text { thermogravimetric analysis } \\ \mathrm{TIC} & \text { total inorganic carbon } \\ \mathrm{TLM} & \text { tank layer model } \\ \mathrm{TOC} & \text { total organic carbon } \\ \mathrm{TWRS} & \text { Tank Waste Remediation System } \\ \mathrm{UL} & \text { upper limit } \\ \text { vol\% } & \text { volume percent } \\ \mathrm{W} & \text { watt } \\ \mathrm{WSTRS} & \text { Waste Status and Transaction Record Summary } \\ \text { wt\% } & \text { weight percent } \\ { }^{\circ} \mathrm{C} & \text { degrees Celsius } \\ \% & \text { percent } \\ \mu \mathrm{Ci} / \mathrm{g} & \text { microcuries per gram } \\ \mu \mathrm{Ci} / \mathrm{gal} & \text { microcuries per gallon } \\ \mu \mathrm{Ci} / \mathrm{mL} & \text { microcuries per milliliter } \\ \mu \mathrm{eq} / \mathrm{g} & \text { microequivalents per gram } \\ \mu \mathrm{eq} / \mathrm{mL} & \text { microequivalents per milliliter } \\ \mu \mathrm{g} / \mathrm{g} & \text { micrograms per gram } \\ \mu \mathrm{g} / \mathrm{mL} & \text { micrograms per milliliter } \\ \mu \mathrm{m} & \text { micrometer } \\ & \end{array}$


HNF-SD-WM-ER-369 Rev. 2

This page intentionally left blank. 


\subsection{INTRODUCTION}

A major function of the Tank Waste Remediation System (TWRS) is to characterize waste in support of waste management and disposal activities at the Hanford Site. Analytical data from sampling and analysis and other available information about a tank are compiled and maintained in a tank characterization report (TCR). This report and its appendices serve as the TCR for single-shell tank 241-T-105.

The objectives of this report are 1) to use characterization data in response to technical issues associated with tank 241-T-105 waste and 2) to provide a standard characterization of this waste in terms of a best-basis inventory estimate. Section 2.0 summarizes the response to technical issues, Section 3.0 shows the best-basis inventory estimate, Section 4.0 makes recommendations about the safety status of the tank and additional sampling needs. The appendices contain supporting data and information. This report supports the requirements of the Hanford Federal Facility Agreement and Consent Order (Ecology et al. 1997), Milestone M-44-15b, change request $M-44-97-03$, to "issue characterization deliverables consistent with the waste information requirements documents developed for 1998."

\subsection{SCOPE}

The characterization information in this report originated from sample analyses and known historical sources. The results of recent sample events will be used to fulfill the requirements of the data quality objectives (DQOs) and memoranda of understanding specified in Brown et al. (1997) for this tank. Other information can be used to support conclusions derived from these results.

Appendix A contains historical information for tank 241-T-105 including surveillance information, records pertaining to waste transfers and tank operations, and expected tank contents derived from a process knowledge model. Appendix B summarizes recent sampling events (see Table 1-1), sample data obtained before 1989, and sampling results. Appendix C reports the statistical analysis and numerical manipulation of data used in issue resolution. Appendix D contains the evaluation to establish the best basis for the inventory estimate and the statistical analysis performed for this evaluation. Appendix $E$ is a bibliography that resulted from an in-depth literature search of all known information sources applicable to tank 241-T-105 and its respective waste types. The reports listed in Appendix E are available in the Tank Characterization and Safety Resource Center. 
Table 1-1. Summary of Recent Sampling.

\begin{tabular}{|c|c|c|c|c|}
\hline ( & 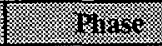 & 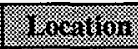 & Sogningutation & $(1200 x+2)$ \\
\hline \multirow{2}{*}{$\begin{array}{l}\text { Core } 205 \\
(6 / 24 / 97 \text { and } 6 / 26 / 97)\end{array}$} & Liquid & \multirow[t]{2}{*}{ Riser 3} & Segment 1 & $100 \%$ \\
\hline & Solid/liquid & & Segment 2 & $31 \%$ \\
\hline \multirow{2}{*}{$\begin{array}{l}\text { Core } 207 \\
(6 / 27 / 97 \text { and } 6 / 30 / 97)\end{array}$} & Solid/liquid & \multirow[t]{2}{*}{ Riser 7} & Segment 1 & $100 \%$ \\
\hline & Solid & & Segment 2 & $82 \%$ \\
\hline \multirow{2}{*}{$\begin{array}{l}\text { Core 53 } \\
(3 / 19 / 93)\end{array}$} & Solid & \multirow[t]{2}{*}{ Riser 8} & Segment 1 & $18 \%$ \\
\hline & Solid/liquid & & Segment 2 & $45 \%$ \\
\hline \multirow{2}{*}{$\begin{array}{l}\text { Core 54 } \\
(3 / 24 / 93)\end{array}$} & Solid/liquid & \multirow[t]{2}{*}{ Riser 2} & Segment 1 & $36 \%$ \\
\hline & Liquid & & Segment 2 & $91 \%^{2}$ \\
\hline \multirow{2}{*}{$\begin{array}{l}\text { Core } 57 \\
(5 / 28 / 93)\end{array}$} & Solid & \multirow[t]{2}{*}{ Riser 5} & Segment 1 & $8 \%$ \\
\hline & Solid & & Segment 2 & $8 \%$ \\
\hline
\end{tabular}

Notes:

'Dates are in the mm/dd/yy format.

${ }^{2}$ Most likely water used as hydrostatic head fluid.

\subsection{TANK BACKGROUND}

Tank 241-T-105 is located in the 200 West Area T Farm on the Hanford Site. It is the second tank in a three-tank cascade series connecting to tank 241-T-104 upstream and to tank 241-T-106 downstream. The tank went into service in 1946, receiving second cycle decontamination waste (2C) from the bismuth phosphate process (Brevick et al. 1997). In 1948, tank 241-T-105 began receiving first cycle decontamination waste (1C), also from the bismuth phosphate process. During its operational life, liquids from the tank were discharged to the cribs, to various tanks, and to the 242-T Evaporator. Other waste types were received by the tank, including coating waste, B Plant low-level waste (BL), and ion-exchange (IX) waste. However, only $2 \mathrm{C}$ and $1 \mathrm{C}$ wastes are predicted to comprise the solids currently in the tank (Agnew et al. 1997). The tank was removed from service in 1976 and interim stabilized in 1987. Intrusion prevention was completed in 1988.

Table 1-2 describes tank 241-T-105. The tank has an operating capacity of 2,010 kL (530 kgal) and contains an estimated $371 \mathrm{~kL}$ (98 kgal) of noncomplexed waste (Hanlon 1998). The tank is not on the Watch List (Public Law 101-510). 
Table 1-2. Description of Tank 241-T-105.

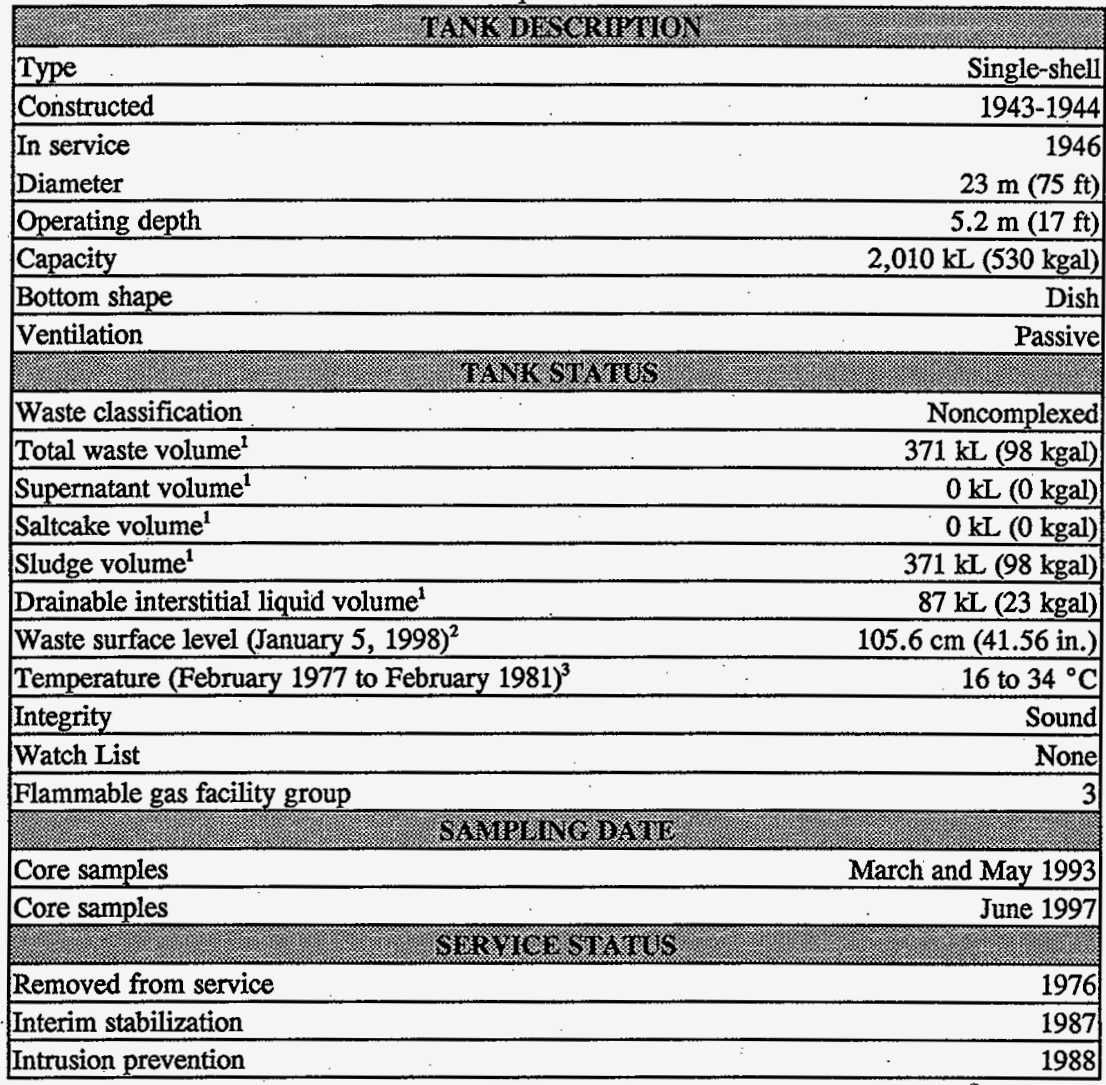

Notes:

${ }^{1}$ Hanlon (1998)

${ }^{2}$ ENRAF is a registered trademark of ENRAF Corporation, Houston, Texas. ENRAF started recording in August 1995. The level was rebaselined to the center of the dish, thus adding $30.5 \mathrm{~cm}(12 \mathrm{in}$.) to the prior level measurement readings. January 5,1998 , was the date of the last surface level measurement before February 28, 1998.

${ }^{3}$ According to Tran (1993), the thermocouple tree was cut off because it could not be removed. There has been no thermocouple tree since May 1982. 
HNF-SD-WM-ER-369 Rev. 2

This page intentionally left blank. 


\subsection{RESPONSE TO TECHNICAL ISSUES}

The following technical issues have been identified for tank 241-T-105:

- Safety Screening: Does the waste pose or contribute to any recognized potential safety problems?

- Organic complexants: Does the possibility exist for a point source ignition in the waste followed by a propagation of the reaction in the solid/liquid phase of the waste?

- Organic solvents: Does an organic solvent pool exist that may cause a fire or ignition of organic solvents in entrained waste solids?

The sampling and analysis plan (SAP) (Field 1997) specifies the types of sampling and analysis used to address the above issues. Data for push core samples was taken in March and May 1993. However, poor recovery was obtained for these sample events, and resampling was recommended. Data from the analysis of push core samples taken in June 1997 provided the means to respond to the technical issues. The response to the technical issues is detailed in the sections below. See Appendix B for sample and analysis data for tank 241-T-105.

\subsection{SAFETY SCREENING}

The data needed to screen the waste in tank 241-T-105 for potential safety problems are documented in Tank Safety Screening Data Quality Objective (Dukelow et al. 1995). These potential safety problems are exothermic conditions in the waste, flammable gases in the waste and/or tank headspace, and criticality conditions in the waste. Each condition is addressed separately below.

\subsubsection{Exothermic Conditions (Energeties)}

The first requirement outlined in the safety screening DQO (Dukelow et al. 1995) is to ensure there are not sufficient exothermic constituents (organic or ferrocyanide) in tank 241-T-105 to pose a safety hazard. Because of this requirement, energetics in tank 241-T-105 waste were evaluated. The safety screening DQO required that the waste sample profile be tested for energetics every $24 \mathrm{~cm}(9.5 \mathrm{in}$.) to determine whether the energetics exceeded the safety threshold limit. The threshold limit for energetics is $480 \mathrm{~J} / \mathrm{g}$ on a dry weight basis. Results obtained using differential scanning calorimetry (DSC) indicated there were no exotherms in any 1997 samples. The maximum exotherm observed in 1993 samples was $334 \mathrm{~J} / \mathrm{g}$ (dry weight). This is below the safety screening limit of $480 \mathrm{~J} / \mathrm{g}$. 
Based on historical process transfer records, there is no evidence that any exothermic agent should exist in this waste. According to Agnew et al. (1997), no fuels are expected in 2C1 (2C waste produced from 1944 to 1949) and 1C2 (1C waste produced from 1950 to 1956), which were predicted to compose the waste in the tank. Although not predicted by Agnew et al. to be present in the tank, other waste types (coating waste) received by the tank did contain small quantities of organics.

\subsubsection{Flammable Gas}

Headspace measurements were taken before taking the June 1997 push core samples. Flammable gas was not detected in the tank headspace ( 0 percent of the lower flammability limit [LFL]) before sampling.

\subsubsection{Criticality}

The safety screening DQO threshold for criticality, based on the total alpha activity, is $1 \mathrm{~g} / \mathrm{L}$. Because total alpha activity is measured in $\mu \mathrm{Ci} / \mathrm{mL}$ instead of $\mathrm{g} / \mathrm{L}$, the $1 \mathrm{~g} / \mathrm{L}$ limit is converted into units of $\mu \mathrm{Ci} / \mathrm{mL}$ by assuming that all alpha decay originates from ${ }^{239} \mathrm{Pu}$. The safety threshold limit is $1 \mathrm{~g}{ }^{239} \mathrm{Pu}$ per liter of waste. Assuming that all alpha is from ${ }^{239} \mathrm{Pu}$, for a maximum sample density of $1.53 \mathrm{~g} / \mathrm{mL}, 1 \mathrm{~g} / \mathrm{L}$ of ${ }^{239} \mathrm{Pu}$ is equivalent to $40.2 \mu \mathrm{Ci} / \mathrm{g}$ of alpha activity. The maximum total alpha activity result was $0.587 \mu \mathrm{Ci} / \mathrm{g}$, well below the notification limit. The maximum total alpha result for 1993 samples was $0.823 \mu \mathrm{Ci} / \mathrm{g}$.

\subsection{ORGANIC COMPLEXANTS}

The data required to support the issue of organic complexants are documented in Memorandum of Understanding for the Organic Complexant Safety Issue Data Requirements (Schreiber 1997). Energetics by DSC and sample moisture analyses were conducted to address the organic complexants issue. As stated previously, no exotherms were observed in any 1997 samples. Although exotherms were observed in 1993 samples, no exothermic activity is expected (see Section 2.1.1), and the tank is classified as "safe" for this issue.

\subsection{ORGANIC SOLVENTS SAFETY SCREENING}

The data required to support the organic solvents safety screening issue are documented in the Data Quality Objective to Support Resolution of the Organic Solvent Safety lssue (Meacham et al. 1997). The DQO requires tank headspace samples be analyzed for total nonmethane organic compounds to determine whether the organic extractant pool in the tank is a hazard. The purpose of this assessment is to ensure an organic solvent pool fire or ignition of organic solvents cannot occur. 
No vapor samples have been taken to estimate the organic pool size. However, the organic program has determined that even if an organic solvent pool does exist, the consequence of a fire or ignition of organic solvents is below risk evaluation guidelines for all tanks (Brown et al. 1998). Consequently, vapor samples are not required for this tank. The organic solvents issue is expected to be closed for all tanks in fiscal year 1998.

\subsection{OTHER TECHNICAL ISSUES}

No vapor samples are planned to address the Data Quality Objective for Tank Hazardous Vapor Safety Screening (Osborne and Buckley 1995) because headspace vapor (sniff) tests are required for the safety screening DQO (Dukelow et al. 1995), and the toxicity issue was closed for all tanks (Hewitt 1996).

A factor in assessing tank safety is the heat generation and temperature of the waste. Heat is generated in the tanks from radioactive decay. Heat load estimates, based on core samples obtained in 1997, were not possible because these samples were not analyzed for radionuclides. An estimate of the tank heat load based on 1993 radionuclide analyses gives a value of $1,310 \mathrm{~W}(4,470 \mathrm{Btu} / \mathrm{hr})$. Table 2-1 shows the heat load estimate. A second heat load estimate of $19.7 \mathrm{~W}(67.3 \mathrm{Btu} / \mathrm{hr})$, based on process history, was available from Agnew et al. (1997). A third estimate based on tank headspace temperatures was $1,461 \mathrm{~W}(4,988 \mathrm{Btu} / \mathrm{hr})$ (Kummerer 1995). All heat load estimates are well below the limit of $11,700 \mathrm{~W}$ $(40,000 \mathrm{Btu} / \mathrm{hr})$ that separates high- and low-heat load tanks (Smith 1986).

Table 2-1. Tank 241-T-105 Projected Heat Load.

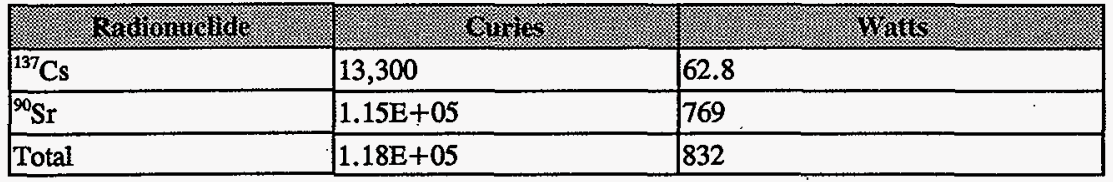

\subsection{SUMMARY}

The results of all analyses performed to address potential safety issues showed that primary analyte(s) did not exceed safety decision threshold limits (Table 2-2). Poor recovery was obtained from the second segment of core 205 . However, excellent recovery was obtained for core 207. Because no exotherms were observed in any samples, the tank is classified as safe for the organics complexants issue. Vapor samples have not been taken for this tank, and no . vapor samples are planned. The organic solvents safety issue is expected to be resolved for all tanks in fiscal year 1998. 
Table 2-2. Summaty of Technical Issues.

\begin{tabular}{|l|l|l|}
\hline \multirow{3}{*}{$\begin{array}{l}\text { Safety } \\
\text { screening }\end{array}$} & Energetics & $\begin{array}{l}\text { No exotherms were observed in } 1997 \text { samples; } 1993 \\
\text { exotherms were below 480 J/g. }\end{array}$ \\
\cline { 2 - 3 } & Flammable gas & $\begin{array}{l}\text { The headspace vapor test showed 0 percent of the LFL } \\
\text { (combustible gas meter). }\end{array}$ \\
\cline { 2 - 3 } & Criticality & $\begin{array}{l}\text { All analytical results were well below the total alpha } \\
\text { activity limits. }\end{array}$ \\
\hline $\begin{array}{l}\text { Organic } \\
\text { complexants }\end{array}$ & $\begin{array}{l}\text { Safety categorization } \\
\text { (safe) }\end{array}$ & $\begin{array}{l}\text { No exotherms observed in } 1997 \text { samples; } 1993 \text { exotherms } \\
\text { were below 480 J/g. The issue is expected to be closed } \\
\text { in fiscal year 1998. }\end{array}$ \\
\hline $\begin{array}{l}\text { Organic } \\
\text { solvent }\end{array}$ & $\begin{array}{l}\text { Organic solvent pool } \\
\text { size }\end{array}$ & $\begin{array}{l}\text { Not vapor sampled. The issue is expected to be closed in } \\
\text { fiscal year 1998. }\end{array}$ \\
\hline
\end{tabular}




\subsection{BEST-BASIS INVENTORY ESTIMATE}

Information about chemical, radiological, and/or physical properties is used to perform safety analyses, engineering evaluations, and risk assessments associated with waste management activities, as well as regulatory issues. These activities include overseeing tank farm operations and identifying, monitoring, and resolving safety issues associated with these operations and with the tank wastes. Disposal activities involve designing equipment, processes, and facilities for retrieving wastes and processing them into a form suitable for long-term storage/disposal.

Chemical and radiological inventory information is generally derived using three approaches: 1) component inventories are estimated using the results of sample analyses; 2) component inventories are predicted using the Hanford defined waste (HDW) model based on process knowledge and historical information; or 3) a tank-specific process estimate is made based on process flowsheets, reactor fuel data, essential material usage, and other operating data.

An effort is underway to provide waste inventory estimates that will serve as the standard characterization for management activities (Hodgson and LeClair 1996). As part of this effort, an evaluation of available chemical information for tank 241-T-105 was performed including the following information:

- Data from core samples from tank 241-T-105 collected in 1997 and 1993

- Representative sample data for $1 \mathrm{C}$ and $\mathrm{BiPO}_{4}$ process aluminum cladding waste (CW) waste types (Kupfer et al. 1997)

- An inventory estimate generated by the HDW model (Agnew et al. 1997).

The evaluation supports using the sample-based results as the best-basis inventory for this tank. Where sample results were not available, engineering evaluations based on sample results for other tanks containing 1C and CW waste (Kupfer et al. 1997) are used as the best basis. Where isotope-specific sample data were not available, HDW model values or a combination of sample results and HDW model values are used to determine radionuclide inventeries.

Best-basis tank inventory values are derived for 46 key radionuclides (Kupfer et al. 1997), all decayed to a common report date of January 1, 1994. Often, waste sample analyses have only reported ${ }^{90} \mathrm{Sr},{ }^{137} \mathrm{Cs},{ }^{239240} \mathrm{Pu}$, and total uranium (or total beta and total alpha), while other key radionuclides such as ${ }^{60} \mathrm{Co},{ }^{99} \mathrm{Tc},{ }^{129} \mathrm{~T},{ }^{154} \mathrm{Eu},{ }^{155} \mathrm{Eu}$, and ${ }^{241} \mathrm{Am}$ have been infrequently reported. For this reason, it has been necessary to derive most of the 46 key radionuclides by computer models. These models estimate radionuclide activity in batches of reactor fuel, account for the split of radionuclides to various separations plant waste streams, and track radionuclide movement with tank waste transactions. These computer models are described in Kupfer et al. (1997), Section 6.1, and in Watrous and Wootan (1997). Model-generated values for 
radionuclides in any of 177 tanks are reported in Agnew et al. (1997). The best-basis value for any one analyte may be either a model result or a sample or engineering assessment-based result, if available.

Tables 3-1 and 3-2 show the best-basis inventory estimate for tank 241-T-105. Simpson (1998) specifies mercury values. Radionuclide curie values are decayed to January 1, 1994.

The inventory values reported in Tables 3-1 and 3-2 are subject to change. Refer to the Tank Characterization Database (LMHC 1998) for the most current inventory values.

Table 3-1. Best-Basis Inventory Estimates for Nonradioactive Components in Tank 241-T-105 (Effective April 1, 1998). (2 sheets)

\begin{tabular}{|c|c|c|c|}
\hline 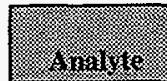 & (6ol & 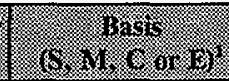 & 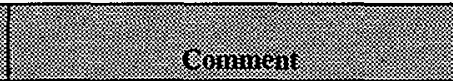 \\
\hline $\mathrm{Al}$ & 26,100 & $\mathbf{S}$ & \\
\hline $\mathrm{Bi}$ & 3,350 & $\mathbf{S}$ & \\
\hline $\mathrm{Ca}$ & 410 & $\mathbf{S}$ & \\
\hline $\mathrm{Cl}$ & 208 & $S$ & \\
\hline $\mathrm{TIC}$ as $\mathrm{CO}_{3}$ & 9,430 & $\mathbf{S}$ & \\
\hline $\mathrm{Cr}$ & 374 & $S$ & \\
\hline $\mathbf{F}$ & 250 & $\mathbf{S}$ & \\
\hline $\mathrm{Fe}$ & 9,430 & $\mathbf{S}$ & \\
\hline $\mathrm{Hg}$ & 8.28 & $E$ & Per change package 7 (Simpson 1998) \\
\hline $\mathbf{K}$ & 259 & $\mathbf{s}$ & \\
\hline $\mathrm{La}$ & 20.20 & $\mathbf{S}$ & \\
\hline $\mathrm{Mn}$ & 4,040 & $s$ & \\
\hline $\mathrm{Na}$ & 34,500 & S & . \\
\hline$\widehat{\mathrm{Ni}}$ & 40.2 & $\mathbf{S}$ & \\
\hline $\mathrm{NO}_{2}$ & 18,220 & $\mathbf{S}$ & \\
\hline $\mathrm{NO}_{3}$ & 12,700 & $\mathbf{S}$ & \\
\hline $\mathrm{OH}_{\text {TOTAL }}$ & 69,700 & C & Charge balance spreadsheet \\
\hline $\mathrm{Pb}$ & 237 & $\mathbf{S}$ & \\
\hline $\mathrm{PO}_{4}$ & 1,610 & $s$ & ICP analysis \\
\hline Si & 1,920 & $\mathbf{S}$ & \\
\hline $\mathrm{SO}_{4}$ & 5,260 & s & IC analysis \\
\hline
\end{tabular}


Table 3-1. Best-Basis Inventory Estimates for Nonradioactive Components in Tank 241-T-105 (Effective April 1, 1998). (2 sheets)

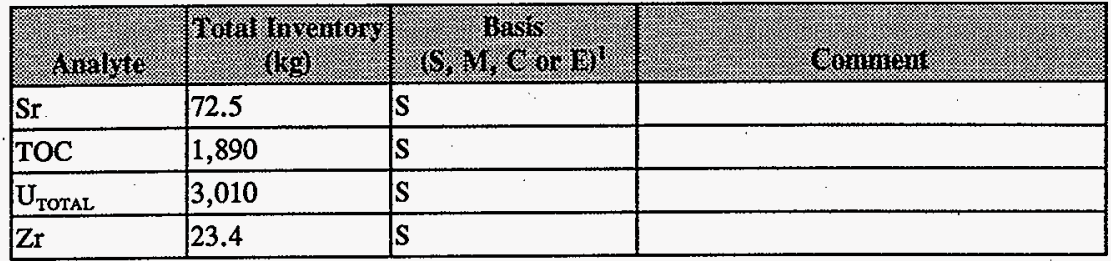

Notes:

IC $=$ Ion chromatography
ICP = inductively coupled plasma spectroscopy
TIC $=$ total inorganic carbon
TOC = $\quad$ total organic carbon

'S = sample-based (see Appendix B), $M=$ HDW model-based, $E=$ engineering assessment, and $\mathrm{C}=$ calculated by charge balance; includes oxides as hydroxides, not inchuding $\mathrm{CO}_{3}, \mathrm{NO}_{2}, \mathrm{NO}_{3}, \mathrm{PO}_{4}, \mathrm{SO}_{4}$, and $\mathrm{SiO}_{3}$.

Table 3-2. Best-Basis Inventory Estimates for Radioactive Components in Tank 241-T-105 Decayed to January 1, 1994 (Effective April 1, 1998). (3 sheets)

\begin{tabular}{|c|c|c|c|}
\hline (2) & 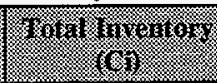 & 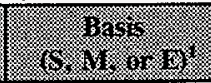 & $\begin{array}{l}\text { II } \\
\text { II }\end{array}$ \\
\hline${ }^{3} \mathrm{H}$ & 4.94 & $\mathbf{S}$ & \\
\hline${ }^{14} \mathrm{C}$ & 0.41 & $S$ & \\
\hline${ }^{59} \mathrm{Ni}$ & 0.00480 & $\mathbf{M}$ & \\
\hline${ }^{60} \mathrm{Co}$ & 15.7 & $S$ & \\
\hline${ }^{63} \mathrm{Ni}$ & 0.435 & $\mathrm{M}$ & \\
\hline${ }^{79} \mathrm{Se}$ & 0.00357 & $\mathbf{M}$ & - \\
\hline${ }^{90} \mathrm{Sr}$ & 115,000 & $\mathbf{S}$ & \\
\hline${ }^{90} \mathbf{Y}$ & 115,000 & $\mathbf{S}$ & Based on ${ }^{90} \mathrm{Sr}$ activity \\
\hline${ }^{93} \mathrm{Zr}$ & 0.0169 & $\mathbf{M}$ & F \\
\hline${ }^{93 \mathrm{~m}} \mathrm{Nb}$ & 0.0142 & $\mathbf{M}$ & \\
\hline${ }^{99} \mathrm{Tc}$ & 153 & $S$ & \\
\hline${ }^{106} \mathrm{Ru}$ & $1.88 \mathrm{E}-09$ & $\mathbf{M}$ & \\
\hline${ }^{113 \mathrm{~m}} \mathrm{Cd}$ & 0.0426 & $\mathbf{M}$ & \\
\hline
\end{tabular}


Table 3-2. Best-Basis Inventory Estimates for Radioactive Components in Tank 241-T-105 Decayed to January 1, 1994 (Effective April 1, 1998). (3 sheets)

\begin{tabular}{|c|c|c|c|}
\hline (3) & 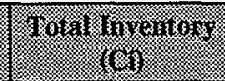 & 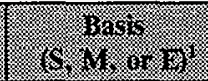 & 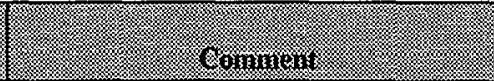 \\
\hline $\mathrm{Sb}$ & 274 & $S$ & \\
\hline${ }^{126} \mathrm{Sn}$ & 0.00538 & $\mathbf{M}$ & \\
\hline 129 & $2.22 \mathrm{E}-04$ & $M$ & $:$ \\
\hline${ }^{134} \mathrm{Cs}$ & 22.7 & $\mathbf{S}$ & \\
\hline${ }^{137} \mathrm{Cs}$ & 13,300 & $\mathbf{S}$ & \\
\hline${ }^{137 \mathrm{~m}} \mathrm{Ba}$ & 12,600 & $S$ & Based on 0.946 of ${ }^{137} \mathrm{Cs}$ activity \\
\hline${ }^{151} \mathrm{Sm}$ & 13.2 & $\mathbf{M}$ & \\
\hline${ }^{152} \mathrm{Eu}$ & 0.00586 & $\mathbf{M}$ & \\
\hline$\overline{154} \mathrm{Eu}$ & 737 & $\mathbf{S}$ & \\
\hline${ }^{155} \mathrm{Eu}$ & 869 & $\mathbf{S}$ & \\
\hline${ }^{226} \mathrm{Ra}$ & $8.76 \mathrm{E}-07$ & $\mathbf{M}$ & \\
\hline${ }^{227} \mathrm{Ac}$ & 4.49E-06 & $\mathbf{M}$ & \\
\hline${ }^{228} \mathrm{Ra}$ & $2.25 \mathrm{E}-11$ & $\mathbf{M}$ & \\
\hline${ }^{229} \mathrm{Th}$ & 4.37E-09 & $\mathbf{M}$ & \\
\hline${ }^{231} \mathrm{~Pa}$ & $9.88 \mathrm{E}-06$ & $\mathbf{M}$ & \\
\hline${ }^{232} \mathrm{Th}$ & $4.74 \mathrm{E}-12$ & $\mathbf{M}$ & \\
\hline${ }^{232} \mathrm{U}$ & $2.29 \mathrm{E}-05$ & $\mathbf{S} / \mathbf{M}$ & $\begin{array}{l}\text { Based on ICP U sample result ratioed to } \\
\text { HDW estimates for U isotopes }\end{array}$ \\
\hline${ }^{233} \mathrm{U}$ & $1.06 \mathrm{E}-06$ & $\mathbf{S} / \mathbf{M}$ & $\begin{array}{l}\text { Based on ICP U sample result ratioed to } \\
\text { HDW estimates for U isotopes }\end{array}$ \\
\hline${ }^{234} \mathrm{U}$ & 0.989 & $\mathbf{S} / \mathbf{M}$ & $\begin{array}{l}\text { Based on ICP U sample result ratioed to } \\
\text { HDW estimates for U isotopes }\end{array}$ \\
\hline${ }^{235} \mathrm{U}$ & 0.0437 & $\mathbf{S} / \mathbf{M}$ & $\begin{array}{l}\text { Based on ICP U sample result ratioed to } \\
\text { HDW estimates for U isotopes }\end{array}$ \\
\hline${ }^{236} \mathrm{U}$ & 0.00983 & $\mathbf{S} / \mathbf{M}$ & $\begin{array}{l}\text { Based on ICP U sample result ratioed to } \\
\text { HDW estimates for U isotopes }\end{array}$ \\
\hline${ }^{237} \mathrm{~Np}$ & $7.28 \mathrm{E}-04$ & $\mathbf{M}$ & 2. \\
\hline${ }^{238} \mathrm{Pu}$ & 0.422 & $\mathrm{~S} / \mathrm{M}$ & $\begin{array}{l}\text { Based on total alpha sample result ratioed } \\
\text { to HDW estimates for alpha isotopes }\end{array}$ \\
\hline${ }^{238} \mathrm{U}$ & 1.01 & $\mathbf{S} / \mathbf{M}$ & $\begin{array}{l}\text { Based on ICP U sample result ratioed to } \\
\text { HDW estimates for U isotopes }\end{array}$ \\
\hline
\end{tabular}


Table 3-2. Best-Basis Inventory Estimates for Radioactive Components in Tank 241-T-105 Decayed to January 1, 1994 (Effective April 1, 1998). (3 sheets)

\begin{tabular}{|c|c|c|c|}
\hline 4 ind & 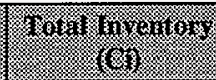 & 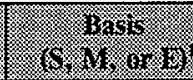 & 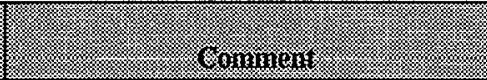 \\
\hline${ }^{239} \mathrm{Pu}$ & 99.1 & S/M & $\begin{array}{l}\text { Based on total alpha sample result ratioed } \\
\text { to HDW estimates for alpha isotopes }\end{array}$ \\
\hline${ }^{240} \mathrm{Pu}$ & 6.68 & S/M & $\begin{array}{l}\text { Based on total alpha sample result ratioed } \\
\text { to HDW estimates for alpha isotopes }\end{array}$ \\
\hline${ }^{241} \mathrm{Am}$ & 99.7 & $S$ & \\
\hline${ }^{241} \mathrm{Pu}$ & 10.6 & $\mathbf{S} / \mathbf{M}$ & $\begin{array}{l}\text { Based on total alpha sample result ratioed } \\
\text { to HDW estimates for alpha isotopes }\end{array}$ \\
\hline${ }^{242} \mathrm{Cm}$ & 0.287 & $\mathbf{S} / \mathbf{M}$ & $\begin{array}{l}\text { Based on total alpha sample result ratioed } \\
\text { to HDW estimates for alpha isotopes }\end{array}$ \\
\hline${ }^{242} \mathrm{Pu}$ & $4.41 \mathrm{E}-05$ & $\mathbf{S} / \mathbf{M}$ & $\begin{array}{l}\text { Based on total alpha sample result ratioed } \\
\text { to HDW estimates for alpha isotopes }\end{array}$ \\
\hline${ }^{243} \mathrm{Am}$ & 7.07E-04 & $\mathbf{S} / \mathbf{M}$ & $\begin{array}{l}\text { Based on total alpha sample result ratioed } \\
\text { to HDW estimates for alpha isotopes }\end{array}$ \\
\hline${ }^{243} \mathrm{Cm}$ & 0.00588 & $\mathrm{~S} / \mathrm{M}$ & $\begin{array}{l}\text { Based on total alpha sample result ratioed } \\
\text { to HDW estimates for alpha isotopes }\end{array}$ \\
\hline${ }^{244} \mathrm{Cm}$ & 0.0168 & $\mathbf{S} / \mathbf{M}$ & $\begin{array}{l}\text { Based on total alpha sample result ratioed } \\
\text { to HDW estimates for alpha isotopes }\end{array}$ \\
\hline
\end{tabular}

Note:

${ }^{1} \mathbf{S}=$ sample-based (see Appendix B), $\mathbf{M}=\mathrm{HDW}$ model-based (Agnew et al. 1997a), and $\mathbf{E}=$ engineering assessment-based. 
HNF-SD-WM-ER-369 Rev. 2

This page intentionally left blank. 


\subsection{RECOMMENDATIONS}

All 1997 core sample analytical results were well within the notification limits for the safety screening DQO (Dukelow et al. 1995). The LFL was 0 percent for this tank. Although sample recovery was poor for core 205 , sample recovery was excellent for core 207 . The 1993 core samples that were recovered also showed all analytical results were well within notification limits for the safety screening DQO. Therefore, the sampling and analysis activities performed for tank 241-T-105 have met all requirements for the safety screening DQO. Vapor samples have not been taken to resolve the organic solvent safety DQO (Meacham et al. 1997). However, the organic solvent issue is expected to be closed for all tanks in fiscal year 1998, and no additional vapor sampling is planned for tank 241-T-105. The tank is classified as safe for the organic complexants issue because no exotherms were observed in any 1997 samples, and exotherms were below $480 \mathrm{~J} / \mathrm{g}$ in 1993 samples.

Table 4-1 summarizes the Project Hanford Management Contractor (PHMC) TWRS Program review status and acceptance of the sampling and analysis results reported in this TCR. All issues required to be addressed by sampling and analysis are listed in column 1 of Table 4-1. Column 2 indicates by "yes" or "no" whether issue requirements were met by the sampling and analysis performed. Column 3 indicates concurrence and acceptance by the program in PHMC/TWRS that is responsible for the applicable issue. A "yes" in column 3 indicates no additional sampling or analyses are needed. Conversely, "no" indicates additional sampling or analysis may be needed to satisfy issue requirements.

Table 4-1. Acceptance of Tank 241-T-105 Sampling and Analysis.

\begin{tabular}{|c|c|c|}
\hline (2) & 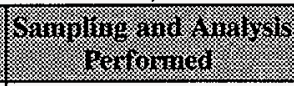 & 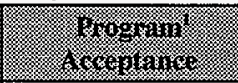 \\
\hline Safety screening data quality objective & Yes & Yes \\
\hline $\begin{array}{l}\text { Organic complexant memorandum of } \\
\text { understanding (Schreiber 1997) }\end{array}$ & Yes & Yes \\
\hline Organic solvents data quality objective ${ }^{2}$ & No & n/a \\
\hline
\end{tabular}

Notes:

$\mathbf{n} / \mathbf{a}=$ not applicable

'PHMC TWRS Program Office

${ }^{2}$ The organic solvent and organic complexant safety issues are expected to be closed in fiscal year 1998. 
Table 4-2 summarizes the status of PHMC TWRS Program review and acceptance of the evaluations and other characterization information contained in this report. Column 1 lists the different evaluations performed in this report. Column 2 shows whether issue evaluations have been completed or are in progress. Column 3 indicates concurrence and acceptance with the evaluation by the program in PHMC/TWRS that is responsible for the applicable issue. A "yes" indicates that the evaluation is completed and meets all issue requirements.

Table 4-2. Acceptance of Evaluation of Characterization Data and Information for Tank 241-T-105.

\begin{tabular}{|c|c|c|}
\hline $\sin (\sqrt[3]{10}$ & 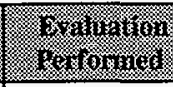 & 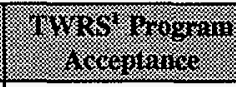 \\
\hline Safety screening data quality objective & Yes & Yes \\
\hline $\begin{array}{l}\text { Organic complexant memorandum of understanding } \\
\text { (Safety classification: Safe) }\end{array}$ & Yes & Yes. \\
\hline Organic solvents data quality objective ${ }^{2}$ & $\mathrm{n} / \mathrm{a}$ & $\mathrm{n} / \mathrm{a}$ \\
\hline
\end{tabular}

Notes:

${ }^{1}$ PHMC TWRS Program Office

${ }^{2}$ The organic solvents issue is expected to be closed in fiscal year 1998. Additional sampling is not required to close this issue for this tank (Brown et al. 1998). 


\subsection{REFERENCES}

Agnew, S. F., J. Boyer, R. A. Corbin, T. B. Duran, J. R. Fitzpatrick, K. A. Jurgensen, T. P. Ortiz, and B. L. Young, 1997, Hanford Tank Chemical and Radionuclide Inventories: HDW Model Rev. 4, LA-UR-96-3860, Rev. 0, Los Alamos National Laboratory, Los Alamos, New Mexico.

Brevick, C. H., J. L. Stroup, and J. W. Funk, 1997, Historical Tank Content Estimate for the Northwest Quadrant of the Hanford 200 West Area, WHC-SD-WM-ER-351, Rev. 1, Fluor Daniel Northwest, Inc. for Fluor Daniel Hanford, Inc., Richland, Washington.

Brown, T. M., J. W. Hunt, and L. J. Fergestrom, 1997, Tank Characterization Technical Sampling Basis, HNF-SD-WM-TA-164, Rev. 3, Lockheed Martin Hanford Corp. for Fluor Daniel Hanford, Inc., Richland, Washington.

Brown, T. M., J. W. Hunt, and L. J. Fergestrom, 1998, Tank Characterization Technical Sampling Basis, HNF-SD-WM-TA-164, Rev. 4, Lockheed Martin Hanford Corp. for Fluor Daniel Hanford, Inc., Richland, Washington.

Dukelow, G. T., J. W. Hunt, H. Babad, and J. E. Meacham, 1995, Tank Safety Screening Data Quality Objective, WHC-SD-WM-SP-004, Rev. 2, Westinghouse Hanford Company, Richland, Washington.

Ecology, EPA, and DOE, 1997. Hanford Federal Facility Agreement and Consent Order, Washington State Department of Ecology, U.S. Environmental Protection Agency, and U.S. Department of Energy, Olympia, Washington.

Field, J. G., 1997, Tank 241-T-105 Push Mode Core Sampling and Analysis Plan, HNF-SD-WM-TSAP-134, Rev. 0C, Lockheed Martin Hanford Corp. for Fluor Daniel Hanford, Inc., Richland, Washington.

Hanlon, B. M., 1998. Waste Tank Summary Report for Month Ending February 28, 1998, HNF-EP-0182-119, Lockheed Martin Hanford Corp. for Fluor Daniel Hanford, Inc., Richland, Washington.

Hewitt, E. R., 1996, Tank Waste Remediation System Resolution of Potentially Hazardous Vapor Issues, WHC-SD-TWR-RPT-001, Rev. 0, Westinghouse Hanford Company, Richland, Washington.

Hodgson K. M., and M. D. LeClair, 1996, Work Plan for Defining A Standard Inventory Estimate for Wastes Stored in Hanford Site Underground Tanks, WHC-SD-WM-WP-311, Rev. 1, Westinghouse Hanford Company, Richland, Washington. 
Kummerer, M., 1995, Topical Report on Heat Removal Characteristics of Waste Storage Tanks, WHC-SD-WM-SARR-010, Rev. 0, Westinghouse Hanford Company, Richland, Washington.

Kupfer, M. J., A. L. Boldt, B. A. Higley, K. M. Hodgson, L. W. Shelton, B. C. Simpson, R. A. Watrous, S. L. Lambert, D. E. Place, R. M. Orme, G. L. Borsheim, N. G. Colton, M. D. LeClair, R. T. Winward, and W. W. Schulz, 1997, Standard Inventories of Chemicals and Radionuclides in Hanford Site Tank Wastes, HNF-SD-WM-TI-740, Rev. 0A, Lockheed Martin Hanford Corp. for Fluor Daniel Hanford, Inc., Richland, Washington.

LMHC, 1998, Best-Basis Inventory for Tank 241-T-105, Tank Characterization Database, Month, Day, Year, Internet at http://twins.pnl.gov:8001/TCD/main.html.

Meacham, J. E., D. L. Banning, M. R. Allen, and L. D. Muhlestein, 1997, Data Quality Objective to Support Resolution of the Organic Solvent Safety Issue, HNF-SD-WM-DQO-026, Rev. 0, DE\&S Hanford, Inc. for Fluor Daniel Hanford, Inc., Richland, Washington.

Osborne, J. W., and L. L. Buckley, 1995, Data Quality Objectives for Taink Hazardous Vapor Safety Screening, WHC-SD-WM-DQO-002, Rev. 2, Westinghouse Hanford Company, Richland, Washington.

Public Law 101-510, 1990, "Safety Measures for Waste Tanks at Hanford Nuclear Reservation," Section 3137 of National Defense Authorization Act for Fiscal Year 1991.

Schreiber, R. D., 1997, Memorandum of Understanding for the Organic Complexant Safety Issue Data Requirements, HNF-SD-WM-RD-060, Rev. 0, Lockheed Martin Hanford Corp. for Fluor Daniel Hanford, Inc.; Richland, Washington.

Simpson, B. C., 1998, Best-Basis Inventory Change Package for Reconciliation of Mercury Values, change package 7 (internal memorandum TA120-98-005 to S. W. Conmann, February 26), Lockheed Martin Hanford Corp. for Fluor Daniel Hanford, Inc., Richland, Washington.

Smith, D. A., 1986, Single-Shell Tank Isolation Safety Analysis Report, WHC-SD-WM-SAR-006, Rev. 2, Westinghouse Hanford Company, Richland, Washington.

Tran, T. T., 1993, Thermocouple Status Single-Shell and Double-Shell Waste Tanks, WHC-SD-WM-TI-553 Rev. 0, Westinghouse Hanford Company, Richland, Washington. 
Watrous, R. A., and D. W. Wootan, 1997, Activity of Fuel Batches Processed Through

Hanford Separations Plants, 1944 Through 1989, HNF-SD-WM-TI-794, Rev. 0, Lockheed Martin Hanford Corp. for Fluor Daniel Hanford, Inc., Richland, Washington. 
HNF-SD-WM-ER-369 Rev. 2

This page intentionally left blank. 
HNF-SD-WM-ER-369 Rev. 2

\section{APPENDIX A}

HISTORICAL TANK INFORMATION 
HNF-SD-WM-ER-369 Rev. 2

This page intentionally left blank. 


\section{APPENDIX A}

\section{HISTORICAL TANK INFORMATION}

Appendix A describes tank 241-T-105 based on historical information. For this report, historical information includes information about the fill history, waste types, surveillance, or modeling data about the tank. This information is necessary for providing a balanced assessment of sampling and analytical results.

This appendix contains the following information:

- Section A1.0: Current tank status including the current waste levels and the tank stabilization and isolation status

- Section A2.0: Information about the tank design

- Section A3.0: Process knowledge about the tank, the waste transfer history, and the estimated contents of the tank based on modeling data

- Section A4.0: Surveillance data for tank 241-T-105, including surface-level readings, temperatures, and a description of the waste surface based on photographs

- Section A5.0: Appendix A references.

\section{A1.0 CURRENT TANK STATUS}

As of November 30, 1997, tank 241-T-105 contained an estimated $371 \mathrm{~kL}$ (98 kgal) of noncomplexed waste. This waste is composed entirely of sludge, with an estimated $87 \mathrm{~kL}$ (23 kgal) of drainable liquid (Hanlon 1998). The solid volume was determined by surface-level measurements, and the liquid volume was determined by photographic evaluation (Hanlon 1998). Table A1-1 shows the volumes of the waste phases found in the tank. Temperature data are not available after February 1981 because no thermocouple tree is currently in this tank. Section A4.0 further discusses waste levels and tank temperatures. Tank 241-T-105 is listed as a low-heat load tank (Hanlon 1998) and is passively ventilated to the atmosphere through a breather filter (Bergmann 1991). Except for temperature readings, monitoring systems are currently in compliance with established standards (Hanlon 1998). 
Tank 241-T-105 is not a Watch List tank (Public Law 101-510). The integrity of the tank is sound. Tank 241-T-105 was removed from service in 1976 and interim stabilized in 1987. Intrusion prevention was completed in 1988.

Table A1-1. Tank 241-T-105 Contents Status Summary. ${ }^{1}$

\begin{tabular}{|l|l|}
\hline \multicolumn{1}{|c|}{ Total waste } & \\
\hline Supernatant & $371 \mathrm{~kL}(98 \mathrm{kgal})$ \\
\hline Siudge & $0 \mathrm{~kL}(0 \mathrm{kgal})$ \\
\hline Saltcake & $371 \mathrm{~kL}(98 \mathrm{kgal})$ \\
\hline Drainable interstitial liquid & $0 \mathrm{~kL}(0 \mathrm{kgal})$ \\
\hline Drainable liquid remaining & $87 \mathrm{~kL}(23 \mathrm{kgal})$ \\
\hline Pumpable liquid remaining & $87 \mathrm{~kL}(23 \mathrm{kgal})$ \\
\hline & $64 \mathrm{~kL}(17 \mathrm{kgal})$ \\
\hline
\end{tabular}

Note:

'Hanlon (1998)

\section{A2.0 TANK DESIGN AND BACKGROUND}

The T Tank Farm, built between 1943 and 1944, was one of the first four tank farms constructed at the Hanford Site. It is the northernmost tank farm in the 200 West Area. The T Farm was designed for nonboiling waste with a maximum fluid temperature of $104{ }^{\circ} \mathrm{C}$. A typical T Farm tank contains 9 to 11 risers, ranging in size from $10 \mathrm{~cm}(4 \mathrm{in}$.) to $1.1 \mathrm{~m}$ (42 in.) in diameter, that provide surface-level access to the underground tank. Generally, there is one riser through the center of the tank dome and four or five each on opposite sides of the dome. These single-shell tanks are constructed of $30 \mathrm{~cm}-(1 \mathrm{ft}-)$ thick reinforced concrete with a $6.4 \mathrm{~mm}(0.25 \mathrm{in}$.) mild carbon steel liner (ASTM A283 Grade C) on the bottom and sides and a $38 \mathrm{~cm}-(1.25 \mathrm{ft}-)$ thick domed concrete top. The tanks have a dished bottom with a $1.2 \mathrm{~m}(4 \mathrm{ft})$ radius knuckle and a $5.2 \mathrm{~m}(17 \mathrm{ft})$ operating depth. The tanks are set on a reinforced concrete foundation. Tank 241-T-105 has a diameter of $23 \mathrm{~m} \mathrm{(75ft)} \mathrm{and} \mathrm{a}$ capacity of $2,010 \mathrm{~kL}$ (530 kgal) (Brevick et al. 1997).

The tank and foundation were waterproofed by a coating of tar covered by a three-ply, asphaltimpregnated, waterproofing fabric. The waterproofing was protected by welded wire reinforced gunite. Two coats of primer were sprayed on all exposed interior surfaces. The tank ceiling dome was covered with three applications of magnesium zincfluorosilicate wash. Lead flashing was used to protect the joint where the steel liner meets the concrete dome. 
Asbestos gaskets were used to seal the risers in the tank dome. The tank was covered with

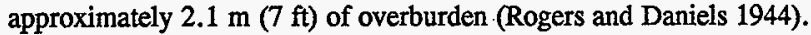

Tank 241-T-105 is the second tank in a "cascade" that connects tanks 241-T-104 and 241-T-106. The tanks are connected by a $7.6 \mathrm{~cm} \mathrm{(3} \mathrm{in.)} \mathrm{cascade} \mathrm{line.} \mathrm{A} \mathrm{cascade} \mathrm{was}$ a system whereby several tanks were connected in series by pipes. The pipes were located at the top of the tanks' working depths. Waste was added to the first tank in a cascade and flowed to the next tank without overfilling the first tank. By using a cascade, fewer connections needed to be made during waste handling operations. This method reduced waste handling requirements, personnel exposure, and the chance of a loss of tank integrity from waste overflow. Another advantage of using the cascades was to clarify the waste. Heavier solids and insoluble constituents would precipitate primarily in the first tank (241-T-104), and the clarified liquids would flow through the cascade to the other tanks (241-T-105 and 241-T-106). This practice led to rapid filling of the first tank with solids and enabled the clarified liquid from the tanks in the cascade to be discharged to cribs.

Figure A2-1 is a plan view of the riser configuration. The figure shows that tank 241-T-105 has four process inlet nozzles, one cascade inlet, and one cascade outlet. Table A2-1 lists tank 241-T-105 risers and shows their sizes and general use.

Figure A2-2 shows a tank cross section and the approximate waste level and a schematic of the tank equipment. Tank 241-T-105 has nine risers. Risers 2, 3, 5, 6, 7, and 8 are tentatively available for sampling (Lipnicki 1997). Risers 2, 3, 6, and 7 are all $30 \mathrm{~cm}$ (12 in.) in diameter. Risers 5 and 8 are $10 \mathrm{~cm}$ (4 in.) in diameter. Risers 2 and 3 are approximately 40 degrees counterclockwise from the inlet, and risers $5,6,7$, and 8 are approximately 70 degrees clockwise from the inlet. 
Figure A2-1. Riser Configuration for Tank 241-T-105.

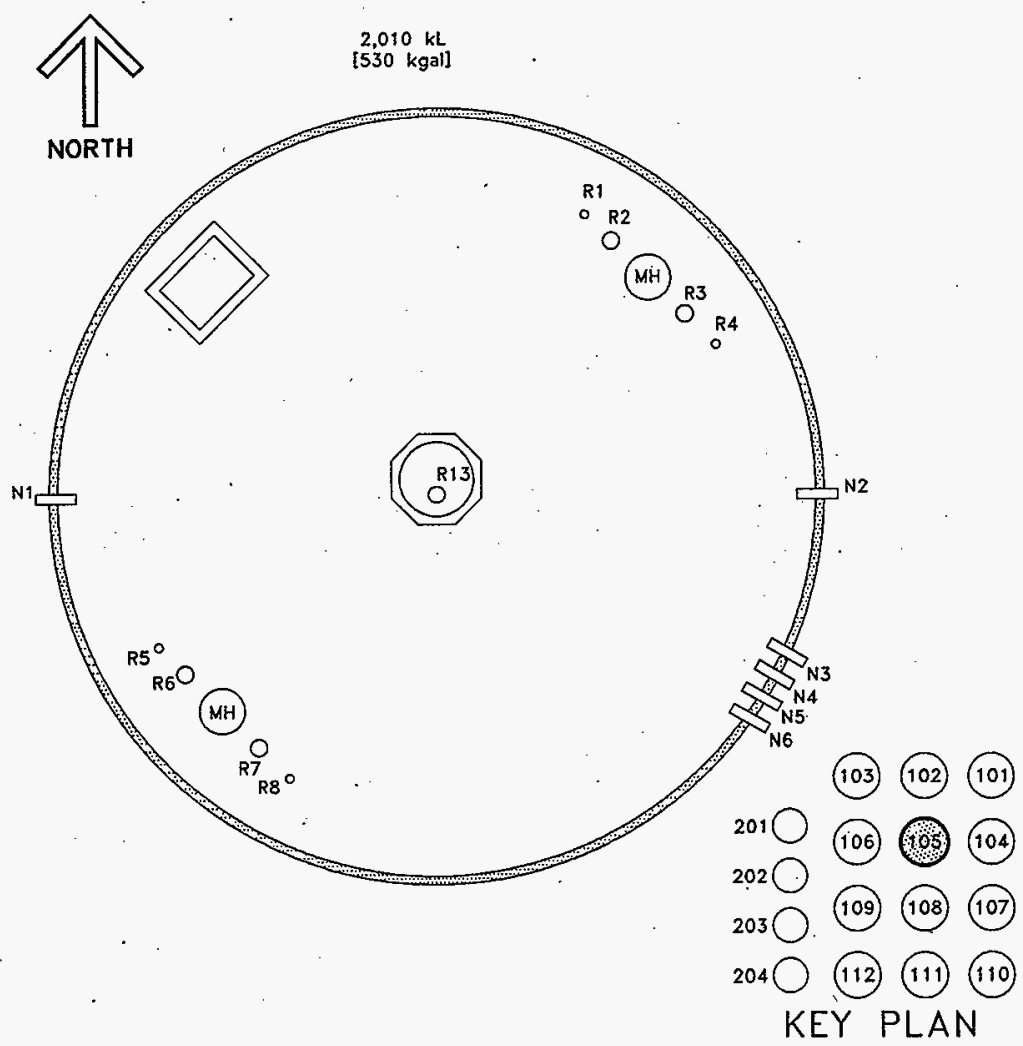


Table A2-1. Tank 241-T-105 Risers. 1, 2,3,4,5

\begin{tabular}{|c|c|c|c|}
\hline & & $4 x_{2}$ & \\
\hline 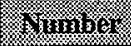 & $\ln (n-1)$ & 13: & 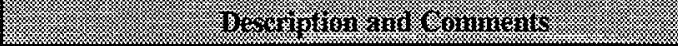 \\
\hline 1 & 10 & 4 & ENRAF'surface level gauge \\
\hline $2^{6}$ & 30 & 12 & B-222 Observation Port (Benchmark December 11, 1986) \\
\hline $3^{6}$ & 30 & 12 & Blank \\
\hline 4 & 10 & 4 & Cut and capped (prior location of thermocouple) \\
\hline $5^{6}$ & 10 & 4 & Breather filter \\
\hline 6 & 30 & 12 & Flange, spare \\
\hline $7^{6}$ & 30 & 12 & Flange, spare \\
\hline $8^{6}$ & 10 & 4 & Flange, spare \\
\hline 13. & 30 & 12 & Salt well (Benchmark December 11, 1986) \\
\hline N1 & 7.6 & 3 & Cascade outlet \\
\hline N2 & 7.6 & 3 & Cascade inlet \\
\hline N3 & 7.6 & 3 & Inlet nozzle, capped \\
\hline N4 & 7.6 & 3 & Inlet nozzle, capped \\
\hline N5 & 7.6 & 3 & Inlet nozzle, capped \\
\hline N6 & 7.6 & 3 & Inlet nozzle, Line V-699 to Diversion Box 241-T-153 \\
\hline
\end{tabular}

Notes:

'Alstad (1993)

${ }^{2}$ Tran (1993)

${ }^{3}$ Vitro Engineering Corporation (1988)

"The parentheses include engineering change notices before 1995.

If there was a discrepancy between the documents and the drawing, the drawing took precedence.

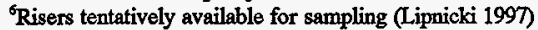




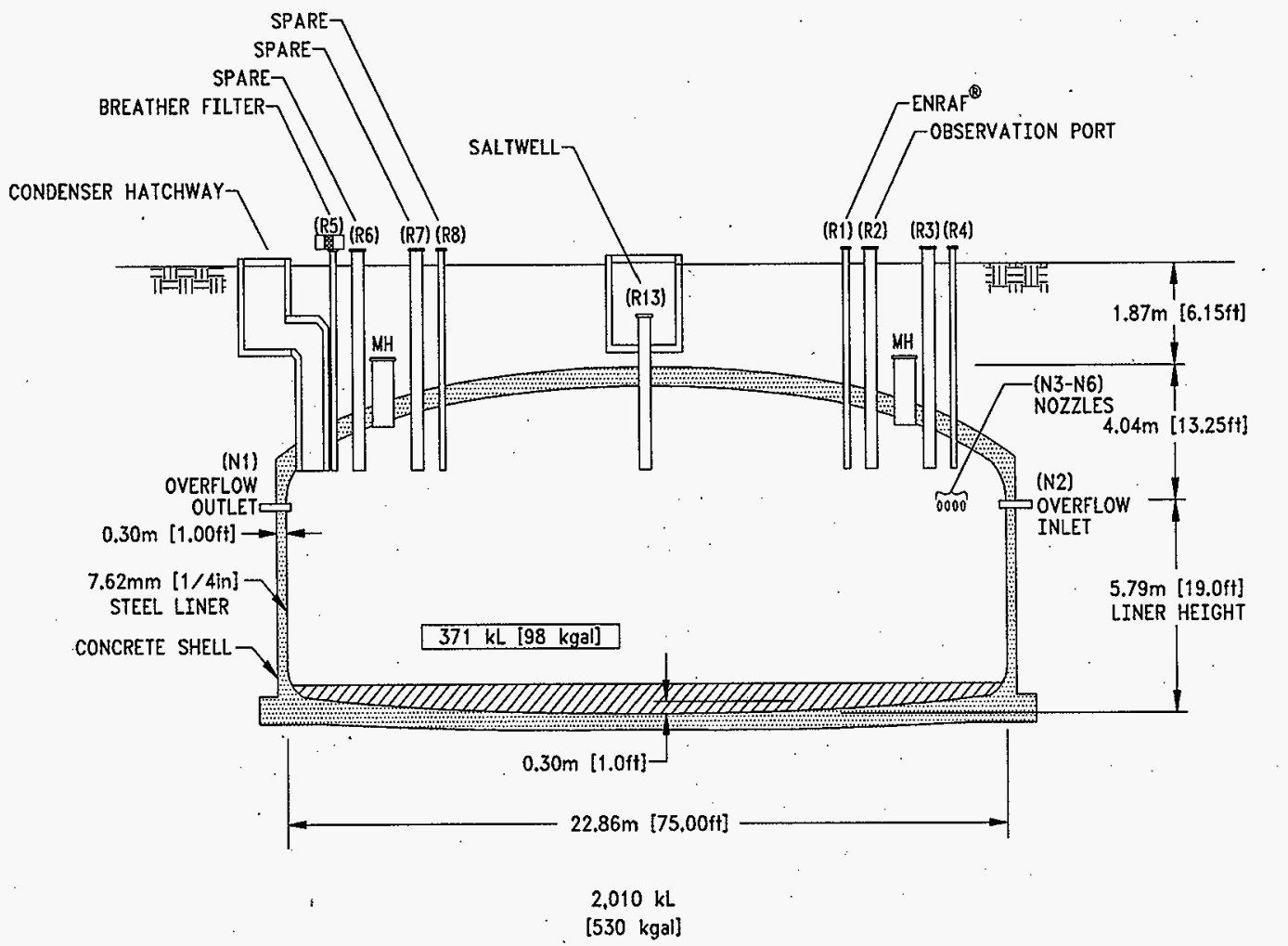

|| 


\section{A3.0 PROCESS KNOWLEDGE}

The sections below 1) provide information about the transfer history of tank 241-T-105, 2) describe the process wastes that made up the transfers, and 3) give an estimate of the current tank contents based on transfer history.

\section{A3.1 WASTE TRANSFER HISTORY}

Table A3-1 summarizes the waste transfer history of tank 241-T-105. The first waste type introduced into tank 241-T-105 was 2C waste in.1946 (Agnew et al. 1997b). This waste consisted of effluent remaining after precipitation of plutonium product in the second decontamination cycle of the $\mathrm{BiPO}_{4}$ process at $\mathrm{T}$ Plant. The $2 \mathrm{C}$ waste filled the tank and cascaded to tank 241-T-106 from 1947 to the first quarter of 1948. Because tank 241-T-105 received waste directly from $\mathrm{T}$-plant, $2 \mathrm{C}$ solids are expected to have been deposited in the lower portion of the tank. In the second quarter of 1948, much of the $2 \mathrm{C}$ supernatant in tank 241-T-105 was sent to the T-107 crib.

From the second quarter of 1948 to the first quarter of $1949,1 \mathrm{C}$ waste cascaded into tank 241-T-105 from tank 241-T-104. Waste cascaded from tank 241-T-105 to tank 241-T-106 during this same period. Produced in the $\mathrm{BiPO}_{4}$ process at $\mathrm{T}$ plant, $1 \mathrm{C}$ waste consisted of by products co-precipitated from a plutonium-containing solution. Coating waste from the removal of aluminum fuel element cladding was also added; it comprised about 24 percent of the waste stream. The $1 \mathrm{C}$ waste is characterized by a relatively high concentration of bismuth and aluminum. During the second quarter of 1951, the waste was transferred from tank 241-T-105 to tanks 241-TX-117 and 241-TX-118. The 1C waste cascaded from tank 241-T-104 to tank 241-T-105 from the fourth quarter of 1951 to the third quarter of 1954. In 1954, the supernatant in tank 241-T-105 was pumped out and sent to a crib. Supernatant waste was also sent to tank 241-TX-118 in the fourth quarter of 1954. The cascade system was not used after 1954.

The tank began receiving CW at the beginning of 1955, and it was full by the end of 1956 . Agnew et al. (1997a) says that CW originated from the reduction oxidation (REDOX) process, but Anderson (1990) says the $\mathrm{CW}$ originated from the $\mathrm{BiPO}_{4}$ process. Waste transaction records in Agnew et al. (1997b) indicate $\mathrm{BiPO}_{4}$ was added rather than REDOX process aluminum cladding waste. Flush water was also added to the waste during 1956.

Tank 241-T-105 received supernatant from tank 241-S-107 in 1965. From 1967 to 1968, supernatant was transferred to tank 241-TX-118 as feed to the 242-T Evaporator. In 1967, Hanford laboratory operations waste was transferred to tank 241-T-105. This dilute waste was generated by laboratories in the 300 Area. In 1968 and 1969, tank 241-T-105 received decontamination waste, a wash solution from equipment decontamination efforts at $T$ Plant. It is composed of a dilute sodium nitrite solution, averaging $0.02 M$ sodium nitrite. 
Tank 241-T-105 received transfers from other single-shell tanks of liquid waste mixtures containing BL and IX wastes in 1973. Supernatant, consisting of most of the tank's volume, was transferred to tank 241-T-106 in the same year. B Plant low-level waste originated from the fractionization plant. Ion exchange waste was a product of the cesium recovery process at B Plant.

In 1974, supernatant waste was transferred to tank 241-S-110. Small supernatant transfers from salt well pumping were made from tanks 241-T-101 and 241-AY-102 in 1976 and 1984, respectively. Table A3-1 shows the estimated cumulative volume of each waste type received and transferred by tank 241-T-105.

Table A3-1. Tank 241-T-105 Major Transfers ${ }^{1,2}$. (2 sheets)

\begin{tabular}{|c|c|c|c|c|c|}
\hline \multirow{2}{*}{ Tyzinger } & \multirow{2}{*}{ 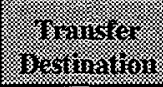 } & \multirow[b]{2}{*}{ 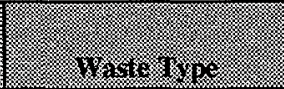 } & \multirow{2}{*}{ 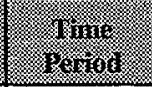 } & \multicolumn{2}{|c|}{ 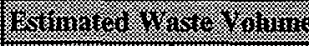 } \\
\hline & & & & 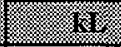 & (1, \\
\hline $\begin{array}{l}\text { Direct from } \\
\text { T-plant }\end{array}$ & - & $2 \mathrm{Cl}$ & 1946-1948 & $+4,012$ & $+1,060$ \\
\hline- & $241-T-106$ & -- & $\begin{array}{l}1946-1949 \\
1951-1954\end{array}$ & $-8,346$ & $-2,205$ \\
\hline- & Crib T-107 & Supernatant & 1948. & $-1,321$ & -349 \\
\hline $241-\mathrm{T}-104$ & - & $1 \mathrm{C}$ & \begin{tabular}{|l}
$1948-1949$ \\
$1951-1954$
\end{tabular} & $+10,955$ & $+2,894$ \\
\hline- & 241-TX-117 & Supernatant & 1951 & -863 & -228 \\
\hline-- & 241-TX-118 & Supernatant & $\begin{array}{l}1951,1954, \\
1967,1968\end{array}$ & $-6,568$ & $-1,735$ \\
\hline$-\cdots$ & Crib & Supernatant & 1954 & $-1,313$ & -347 \\
\hline REDOX & - & $\mathrm{CW}^{3}$ & $1955-1956$ & +980 & +259 \\
\hline Flush water & - & Flush water & 1955-1956 & +314 & +83 \\
\hline $241-S-107$ & - & Supernatant & 1965 & +83 & +22 \\
\hline $\begin{array}{l}300 \text { Area } \\
\text { Laboratories }\end{array}$ & - & Laboratory waste & 1967 & $+1,499$ & +396 \\
\hline T Plant & -- & Decontamination waste & 1968-1969 & $+1,230$ & +325 \\
\hline BX-104 & - & $\mathrm{BL}, \mathrm{IX}$ & $1972-1973$ & $+1,435$ & +379 \\
\hline
\end{tabular}


Table A3-1. Tank 241-T-105 Major Transfers ${ }^{1,2}$. (2 sheets)

\begin{tabular}{|c|c|c|c|c|c|}
\hline \multirow{2}{*}{ Hitinger } & \multirow{2}{*}{ 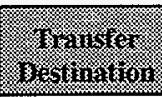 } & \multirow[b]{2}{*}{ 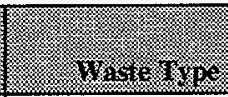 } & \multirow{2}{*}{ 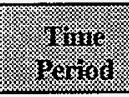 } & \multicolumn{2}{|c|}{ 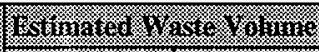 } \\
\hline & & & & (3) & 8.8 .91 \\
\hline 241-T-107 & - & $\mathrm{BL}, \mathrm{IX}$ & 1973 & $+1,711$ & +452 \\
\hline-- & $\begin{array}{l}\text { 241-T-106, } \\
\text { S-110, T-101 }\end{array}$ & Supernatant & $1973-1975$ & $-3,335$ & -881 \\
\hline-- & AY-102 & Salt well liquid & 1984 & -64 & -17 \\
\hline
\end{tabular}

Notes:

'Agnow et al. (1997b)

${ }^{2}$ Because only major transfers are listed, the sum of transfers will not equal the current tank waste volume.

${ }^{3}$ Anderson (1990)

\section{A3.2 HISTORICAL ESTIMATION OF TANK CONTENTS}

The historical transfer data used for this estimate are from the following sources:

- The Waste Status and Transaction Record Summary: WSTRS, Rev. A, (Agnew et al. 1997b) is a tank-by-tank quarterly summary spreadsheet of waste transactions.

- The Hanford Tank Chemical and Radionuclide Inventories: HDW Model Rev. 4 (Agnew et al. 1997a) contains the Hanford defined waste (HDW) list, the supernatant mixing model (SMM), the tank layer model (TLM), and the historical tank content estimate (HTCE).

- The HDW list is comprised of approximately 50 waste types defined by concentration for major analytes/compounds for sludge and supernatant layers.

- The TLM defines the sludge and saltcake layers in each tank using waste composition and waste transfer information.

- The SMM is a subroutine within the HDW model that calculates the volume and composition of certain supernatant blends and concentrates.

Using these records, the TLM defines the sludge and saltcake layers in each tank. The SMM uses information from the WSTRS, the TLM, and the HDW list to describe the supernatants and concentrates in each tank. Together the WSTRS, TLM, SMM, and HDW list determine the inventory estimate for each tank. These model predictions are considered estimates that require further evaluation using analytical data. 
Based on Agnew et al. (1997a), tank 241-T-105 contains a bottom layer of $270 \mathrm{~kL}$ (72 kgal) of $2 \mathrm{C} 1$ waste and a top layer of $98 \mathrm{~kL}$ ( $26 \mathrm{kgal}$ ) of $1 \mathrm{C} 2$ waste. The $2 \mathrm{Cl}$ waste type is $2 \mathrm{C}$ waste produced from 1944 to 1949 . The 1C2 waste type is 1C waste generated from 1950 to 1956. Figure A3-1 is a graphical representation of the estimated waste type and volume for the tank layers. Both the $2 \mathrm{C} 1$ and $1 \mathrm{C} 2$ waste types are predicted to contain greater than 1 weight percent of sodium, hydroxide, nitrate, and phosphate, and between 1 and 0.1 weight percent of sulfate, calcium, carbonate, silicate and fluoride. Bismuth and iron are predicted above 1 weight percent for $2 \mathrm{Cl}$ waste, and aluminum is predicted at greater than 1 weight percent for $1 C 2$ waste. Table A3-2 shows the historical estimate of the expected tank waste constituents and their concentrations.

Figure A3-1. Tank Layer Model.

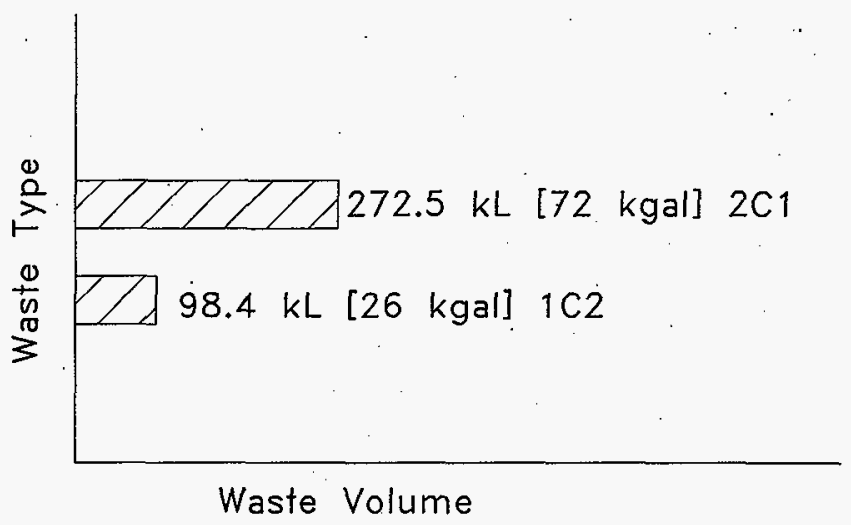


Table A3-2. Historical Tank Inventory Estimate. ${ }^{1,2}$ (4 sheets)

\begin{tabular}{|c|c|c|c|c|c|}
\hline স্য: & 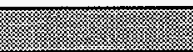 & trof 1 lingrin & $43 \ln 11010$ & & \\
\hline y) & 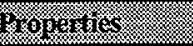 & 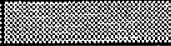 & (3) & 105 & 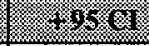 \\
\hline Total waste & $4.75 \mathrm{E}+05(\mathrm{~kg})$ & $(98.0 \mathrm{kgal})$ & --- & - & --- \\
\hline Heat load & $1.97 \mathrm{E}-02(\mathrm{~kW})$ & $(67.3 \mathrm{Btu} / \mathrm{hr})$ & --- & $1.36 \mathrm{E}-02$ & $2.57 \mathrm{E}-02$ \\
\hline Bulk density ${ }^{3}$ & $1.28\left(\mathrm{~g} / \mathrm{cm}^{3}\right)$ & - & - & 1.18 & 1.36 \\
\hline Water wt $\%^{3}$ & 69.7 & $-\cdots$ & $\ldots$ & 64.3 & 77.2 \\
\hline $\begin{array}{l}\text { TOC wt\% C } \\
\text { (wet) }^{3}\end{array}$ & 0 & - & - & 0 & 0 \\
\hline 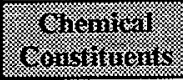 & 18 & (3) & 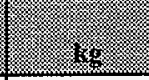 & 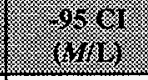 & 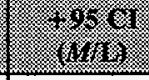 \\
\hline $\mathrm{Na}^{+}$ & 4.40 & $7.90 \mathrm{E}+04$ & $3.75 \mathrm{E}+04$ & 2.46 & 6.16 \\
\hline $\mathrm{Al}^{3+}$ & 0.115 & $2.43 \mathrm{E}+03$ & $1.15 \mathrm{E}+03$ & 0.115 & 0.115 \\
\hline $\mathrm{Fe}^{3+}$ (total $\left.\mathrm{Fe}\right)$ & 0.502 & $2.19 \mathrm{E}+04$ & $1.04 \mathrm{E}+04$ & 0.492 & 0.511 \\
\hline $\mathrm{Cr}^{3+}$ & $3.73 \mathrm{E}-03$ & 152 & 72.0 & 3.24E-03 & $4.22 \mathrm{E}-03$ \\
\hline $\mathrm{Bi}^{3+}$ & 8.37E-02 & $1.37 \mathrm{E}+04$ & $6.49 \mathrm{E}+03$ & $6.50 \mathrm{E}-02$ & $9.37 \mathrm{E}-02$ \\
\hline $\mathrm{La}^{3+}$ & 0 & 0 & 0 & 0 & 0 \\
\hline $\mathrm{Hg}^{2+}$ & $2.48 \mathrm{E}-05$ & 3.89 & 1.85 & $5.54 \mathrm{E}-06$ & $3.11 \mathrm{E}-05$ \\
\hline $\begin{array}{l}\mathrm{Zr} \text { (as } \\
\left.\mathrm{ZrO}(\mathrm{OH})_{2}\right)\end{array}$ & $6.50 \mathrm{E}-05$ & 4.63 & 2.20 & $4.07 \mathrm{E}-05$ & $8.90 \mathrm{E}-05$ \\
\hline $\mathrm{Pb}^{2+}$ & 0 & 0 & 0 & 0 & 0 \\
\hline $\mathrm{Ni}^{2+}$ & $1.24 \mathrm{E}-03$ & 57.1 & 27.1 & $1.12 \mathrm{E}-03$ & 3.99E-03 \\
\hline $\mathrm{Sr}^{2+}$ & 0 & 0 & 0 & 0 & 0 \\
\hline $\mathrm{Mn}^{4+}$ & 0 & 0 & 0 & 0 & 0 \\
\hline $\mathrm{Ca}^{2+}$ & 0.125 & $3.91 E+03$ & $1.86 \mathrm{E}+03$ & $8.30 \mathrm{E}-02$ & 0.160 \\
\hline $\mathrm{K}^{+}$ & $5.59 \mathrm{E}-03$ & 171 & 81.1 & $4.90 \mathrm{E}-03$ & $6.27 \mathrm{E}-03$ \\
\hline $\mathrm{OH}^{-}$ & 2.19 & $2.90 \mathrm{E}+04$ & $1.38 \mathrm{E}+04$ & 2.13 & 2.27 \\
\hline $\mathrm{NO}_{3}^{-}$ & 0.958 & $4.64 \mathrm{E}+04$ & $2.20 \mathrm{E}+04$ & 0.870 & 1.03 \\
\hline $\mathrm{NO}_{2}^{-}$ & $9.56 \mathrm{E}-02$ & $3.44 \mathrm{E}+03$ & $1.63 E+03$ & $4.69 \mathrm{E}-02$ & 0.164 \\
\hline $\mathrm{CO}_{3}^{2-}$ & 0.125 & $5.86 \mathrm{E}+03$ & $2.78 \mathrm{E}+03$ & $8.30 \mathrm{E}-02$ & 0.160 \\
\hline $\mathrm{PO}_{4}{ }^{3-}$ & 1.04 & $7.72 \mathrm{E}+04$ & $3.67 \mathrm{E}+04$ & 0.443 & 1.41 \\
\hline $\mathrm{SO}_{4}^{2-}$ & $4: 26 \mathrm{E}-02$ & $3.20 \mathrm{E}+03$ & $1.52 \mathrm{E}+03$ & $3.74 \mathrm{E}-02$ & $4.79 \mathrm{E}-02$ \\
\hline
\end{tabular}


Table A3-2. Historical Tank Inventory Estimate. ${ }^{1,2}$ (4 sheets)

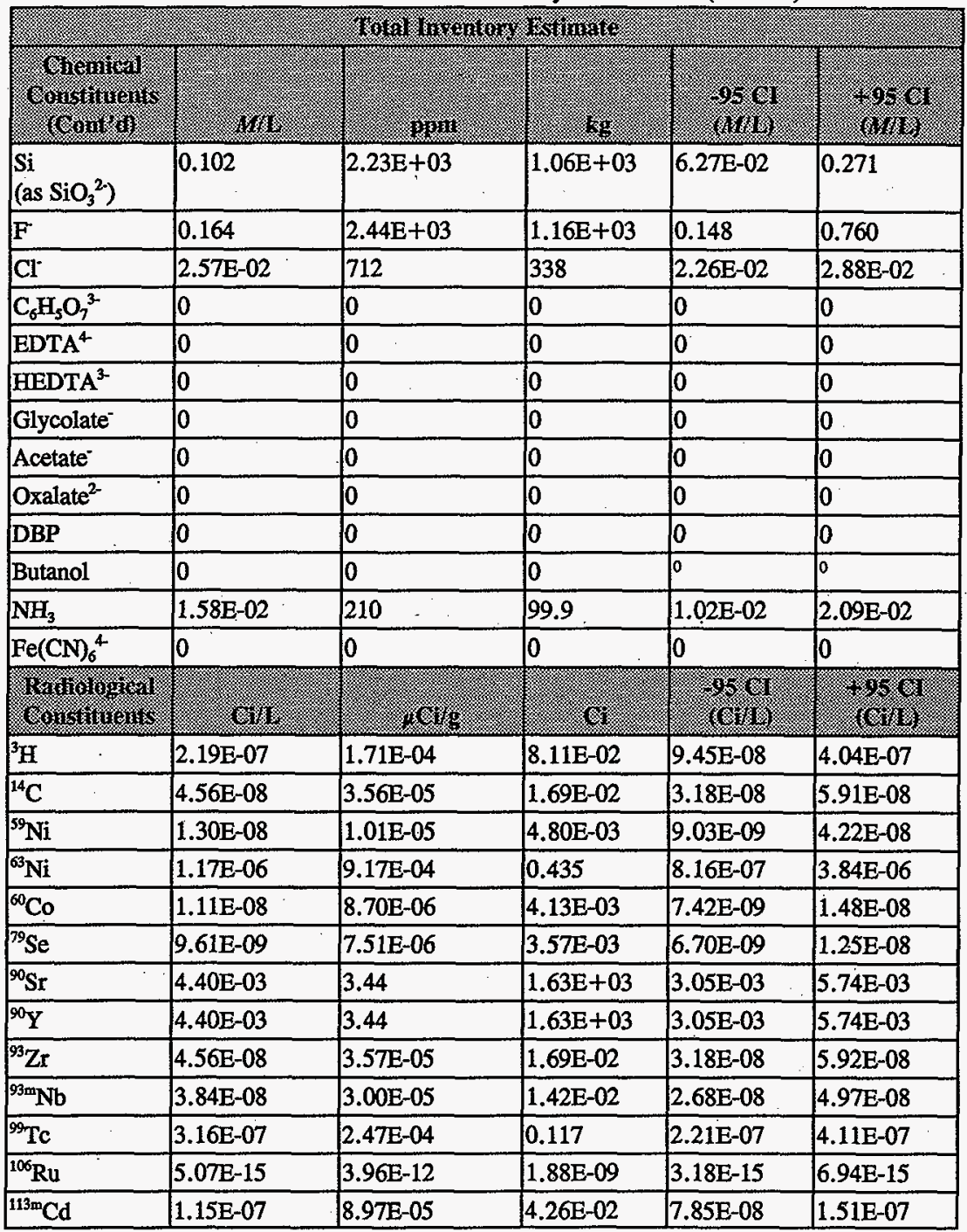


HNF-SD-WM-ER-369 Rev. 2

Table A3-2. Historical Tank Inventory Estimate. ${ }^{1,2}$ (4 sheets)

\begin{tabular}{|c|c|c|c|c|c|}
\hline & & 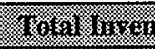 & 3 & & \\
\hline 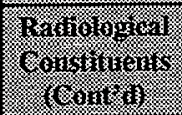 & (1) & $\left(\frac{1}{4}\right.$ & l & (3) & . \\
\hline${ }^{125} \mathrm{Sb}$ & $1.07 \mathrm{E}-08$ & $8.40 \mathrm{E}-06$ & 3.99E-03 & $6.97 \mathrm{E}-09$ & $1.45 \mathrm{E}-08$ \\
\hline${ }^{126} \mathrm{Sn}$ & $1.45 \mathrm{E}-08$ & $1.13 \mathrm{E}-05$ & 5.38E-03 & $1.01 \mathrm{E}-08$ & $1.88 \mathrm{E}-08$ \\
\hline${ }^{129} \mathrm{I}$ & 5.97E-10 & 4.67E-07 & 2.22E-04 & $4.16 \mathrm{E}-10$ & $7.76 \mathrm{E}-10$ \\
\hline${ }^{134} \mathrm{Cs}$ & $4.62 \mathrm{E}-10$ & $3.61 \mathrm{E}-07$ & 1.71E-04 & $2.93 \mathrm{E}-10$ & $6.28 \mathrm{E}-10$ \\
\hline${ }^{137} \mathrm{Cs}$ & $5.00 \mathrm{E}-03$ & 3.91 & $1.86 \mathrm{E}+03$ & $3.46 \mathrm{E}-03$ & $6.52 \mathrm{E}-03$ \\
\hline${ }^{137 \mathrm{~m}} \mathrm{Ba}$ & 4.73E-03 & 3.70 & $1.76 \mathrm{E}+03$ & $3.28 \mathrm{E}-03$ & $6.17 \mathrm{E}-03$ \\
\hline${ }^{151} \mathrm{Sm}$ & $3.57 \mathrm{E}-05$ & $2.79 \mathrm{E}-02$ & 13.2 & 2.49E-05 & $4.63 \mathrm{E}-05$ \\
\hline${ }^{152} \mathrm{Eu}$ & $1.58 \mathrm{E}-08$ & $1.23 \mathrm{E}-05$ & $5.86 \mathrm{E}-03$ & 1.53E-08 & $1.63 \mathrm{E}-08$ \\
\hline${ }^{154} \mathrm{Eu}$ & $2.06 \mathrm{E}-07$ & $1.61 \mathrm{E}-04$ & 7.63E-02 & $1.35 \mathrm{E}-07$ & $2.76 \mathrm{E}-07$ \\
\hline${ }^{155} \mathrm{Eu}$ & $1.19 \mathrm{E}-06$ & $9.32 \mathrm{E}-04$ & 0.443 & $1.16 \mathrm{E}-06$ & $1.23 \mathrm{E}-06$ \\
\hline${ }^{226} \mathrm{Ra}$ & $2.36 \mathrm{E}-12$ & 1.85E-09 & $8.76 \mathrm{E}-07$ & $1.77 \mathrm{E}-12$ & $2.94 \mathrm{E}-12$ \\
\hline${ }^{228} \mathrm{Ra}$ & $6.07 \mathrm{E}-17$ & $4.74 \mathrm{E}-14$ & $2.25 \mathrm{E}-11$ & $5.92 \mathrm{E}-17$ & $6.21 \mathrm{E}-17$ \\
\hline${ }^{22} \mathrm{Ac}$ & $1.21 \mathrm{E}-11$ & $9.47 \mathrm{E}-09$ & 4.49E-06 & $9.06 \mathrm{E}-12$ & $1.51 \mathrm{E}-11$ \\
\hline${ }^{231} \mathrm{~Pa}$ & $2.66 \mathrm{E}-11$ & $2.08 \mathrm{E}-08$ & $9.88 \mathrm{E}-06$ & $1.98 \mathrm{E}-11$ & 3.34E-11 \\
\hline${ }^{229} \mathrm{Th}$ & $1.18 \mathrm{E}-14$ & $9.20 \mathrm{E}-12$ & 4.37E-09 & $1.15 \mathrm{E}-14$ & $1.21 \mathrm{E}-14$ \\
\hline${ }^{232} \mathrm{Th}$ & $1.28 \mathrm{E}-17$ & $9.99 \mathrm{E}-15$ & 4.74E-12 & 9.01E-18 & $1.65 \mathrm{E}-17$ \\
\hline${ }^{232} \mathrm{U}$ & $9.70 \mathrm{E}-11$ & $7.58 \mathrm{E}-08$ & $3.60 \mathrm{E}-05$ & $8.25 \mathrm{E}-11$ & $1.06 \mathrm{E}-10$ \\
\hline${ }^{233} \mathrm{U}$ & $4.49 \mathrm{E}-12$ & $3.51 \mathrm{E}-09$ & $1.67 \mathrm{E}-06$ & $3.83 \mathrm{E}-12$ & $5.05 \mathrm{E}-12$ \\
\hline${ }^{234} \mathrm{U}$ & $4.20 \mathrm{E}-06$ & $3.28 \mathrm{E}-03$ & 1.56 & $3.59 \mathrm{E}-06$ & $4.98 \mathrm{E}-06$ \\
\hline${ }^{235} \mathrm{U}$ & $1.86 \mathrm{E}-07$ & $1.45 \mathrm{E}-04$ & $6.88 \mathrm{E}-02$ & $1.59 \mathrm{E}-07$ & 2.21E-07 \\
\hline${ }^{236} \mathrm{U}$ & 4.17E-08 & $3.26 \mathrm{E}-05$ & $1.55 \mathrm{E}-02$ & $3.56 \mathrm{E}-08$ & 4.68E-08 \\
\hline${ }^{238} \mathrm{U}$ & 4.26E-06 & $3.33 \mathrm{E}-03$ & 1.58 & $3.65 \mathrm{E}-06$ & $5.06 \mathrm{E}-06$ \\
\hline${ }^{237} \mathrm{~Np}$ & $1.96 \mathrm{E}-09$ & $1.53 \mathrm{E}-06$ & $7.28 \mathrm{E}-04$ & $1.36 \mathrm{E}-09$ & 2.55E-09 \\
\hline${ }^{238} \mathrm{Pu}$ & $2.86 \mathrm{E}-07$ & 2.23E-04 & 0.106 & $1.43 \mathrm{E}-07$ & $4.92 \mathrm{E}-07$ \\
\hline${ }^{239} \mathrm{Pu}$ & $6.70 \mathrm{E}-05$ & $5.24 \mathrm{E}-02$ & 24.9 & $2.24 \mathrm{E}-05$ & 1.32E-04 \\
\hline${ }^{240} \mathrm{Pu}$ & 4.52E-06 & $3.53 \mathrm{E}-03$ & 1.68 & $1.89 \mathrm{E}-06$ & 8.33E-06 \\
\hline${ }^{241} \mathrm{Pu}$ & 7.18E-06 & 5.61E-03 & 2.66 & 2.67E-06 & $1.08 \mathrm{E}-05$ \\
\hline${ }^{242} \mathrm{Pu}$ & $2.98 \mathrm{E}-11$ & 2.33E-08 & 1.11E-05 & $9.24 \mathrm{E}-12$ & 4.62E-11 \\
\hline${ }^{241} \mathrm{Am}$ & $1.00 \mathrm{E}-07$ & $7.83 \mathrm{E}-05$ & 3.72E-02 & 6.38E-08 & $1.36 \mathrm{E}-07$ \\
\hline
\end{tabular}


Table A3-2. Historical Tank Inventory Estimate. ${ }^{1,2}$ (4 sheets)

\begin{tabular}{|c|c|c|c|c|c|}
\hline \multicolumn{6}{|c|}{ 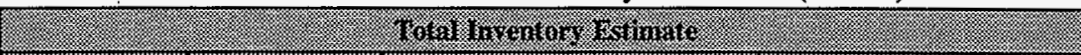 } \\
\hline 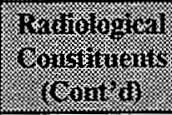 & ( & $4 x$ & (2) & 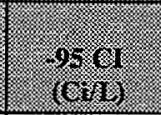 & $\frac{19}{(61)}$ \\
\hline${ }^{243} \mathrm{Am}$ & $7.11 \mathrm{E}-13$ & $5.56 \mathrm{E}-10$ & $2.64 \mathrm{E}-07$ & $4.48 \mathrm{E}-13$ & $9.71 \mathrm{E}-13$ \\
\hline${ }^{242} \mathrm{Cm}$ & $2.89 \mathrm{E}-10$ & $2.26 \mathrm{E}-07$ & 1.07E-04 & $2.79 \mathrm{E}-10$ & $2.99 \mathrm{E}-10$ \\
\hline${ }^{243} \mathrm{Cm}$ & $5.92 \mathrm{E}-12$ & $4.62 \mathrm{E}-09$ & 2.19E-06 & $5.70 \mathrm{E}-12$ & $6.13 \mathrm{E}-12$ \\
\hline${ }^{244} \mathrm{Cm}$ & $1.69 \mathrm{E}-11$ & $1.32 \mathrm{E}-08$ & $6.26 \mathrm{E}-06$ & $1.06 \mathrm{E}-11$ & 2.31E-11 \\
\hline 17015 & (3) & 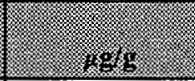 & 8 & 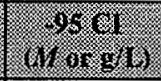 & 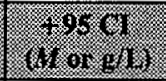 \\
\hline $\mathrm{Pu}$ & $1.10 \mathrm{E}-03(\mathrm{~g} / \mathrm{L})$ & -- & 0.407 & $3.68 \mathrm{E}-04$ & $2.16 \mathrm{E}-03$ \\
\hline $\mathbf{U}$ & 5.37E-02 & $9.98 \mathrm{E}+03$ & $4.74 \mathrm{E}+03$ & $4.60 \mathrm{E}-02$ & $6.37 \mathrm{E}-02$ \\
\hline
\end{tabular}

Notes:

$\mathrm{CI}=$ confidence interval

'Unknowns in tank solids inventory are assigned by the TLM.

${ }^{2}$ Historical tank inventory estimates have not been validated and should be used with caution.

${ }^{3}$ Volume average for density, mass average water weight percent, and TOC weight percent $C$.

\section{A4.0 SURVEILLANCE DATA}

Tank 241-T-105 surveillance consists of surface-level measurements, temperature monitoring, and dry well monitoring for radioactivity outside the tank. Surveillance data provide the basis for determining tank integrity. Liquid-level measurements can indicate whether the tank has a major leak. Solid surface-level measurements indicate physical changes in consistency of the solid layers of a tank. Dry wells located around the tank perimeter may show increased radioactivity caused by leaks in the vicinity of the dry wells.

\section{A4.1 SURFACE-LEVEL READINGS}

An ENRAF ${ }^{\circ}$ surface-level gauge was installed in July 1995 . Before this, surface-level readings were taken by Food Instrument Corporation in intrusion mode. Surface-level measurements are manually entered into the Computer Automated Surveillance System. Surface-level data from 1991 to 1996 show a steady waste level. In January 1996, the location 
for surface-level measurements was changed from the tank side wall to near the tank center. Figure A4-1 shows the level history data. The waste surface level on January 5, 1998, was $105.6 \mathrm{~cm}(41.6 \mathrm{in}$.).

\section{A4.2 INTERNAL TANK TEMPERATURES}

Historical temperature data from 1977 to 1981 ranged from $16{ }^{\circ} \mathrm{C}$ to $34^{\circ} \mathrm{C}$ (see Figure A4-2). The last available temperature reading for tank 241-T-105 was $23{ }^{\circ} \mathrm{C}$ taken February 1981. The thermocouple tree was cut off in 1981 (Brevick et al. 1997).

Tank 241-T-105 has not received waste since it was removed from service in 1976, but $64 \mathrm{~kL}$ $(17 \mathrm{kgal})$ of supernatant waste has been removed. This may have affected the tank temperature. Also, historical temperatures may. be higher than current temperatures because radiation-generated heat decreases as radioactive constituents decay over time.

\section{A4.3 DRY WELL RADIOACTIVITY}

Two dry wells were drilled around tank 241-T-105 in 1973, and another dry well was drilled in 1975 . These dry wells have registered high radioactivity. The dry well closest to tank 241-T-106 had greater than $200 \mathrm{c} / \mathrm{s}$. The remaining two had greater than $50 \mathrm{c} / \mathrm{s}$ before 1990. The radioactivity has been attributed to an estimated $435 \mathrm{~kL}$ (115 kgal) leak from tank 241-T-106 (Welty 1988).

\section{A4.4 TANK 241-T-105 PHOTOGRAPHS}

The 1976 photographic montage of the inside of tank 241-T-105 shows a black, uneven surface that appears to have a medium-brown colored material underneath. In part of the montage, a small amount of liquid appears to be on the waste surface. Some liquids have evaporated since 1987, but the photograph probably represents current tank contents (Brevick et al. 1997). 
Figure A4-1. Tank 241-T-105 Level History.

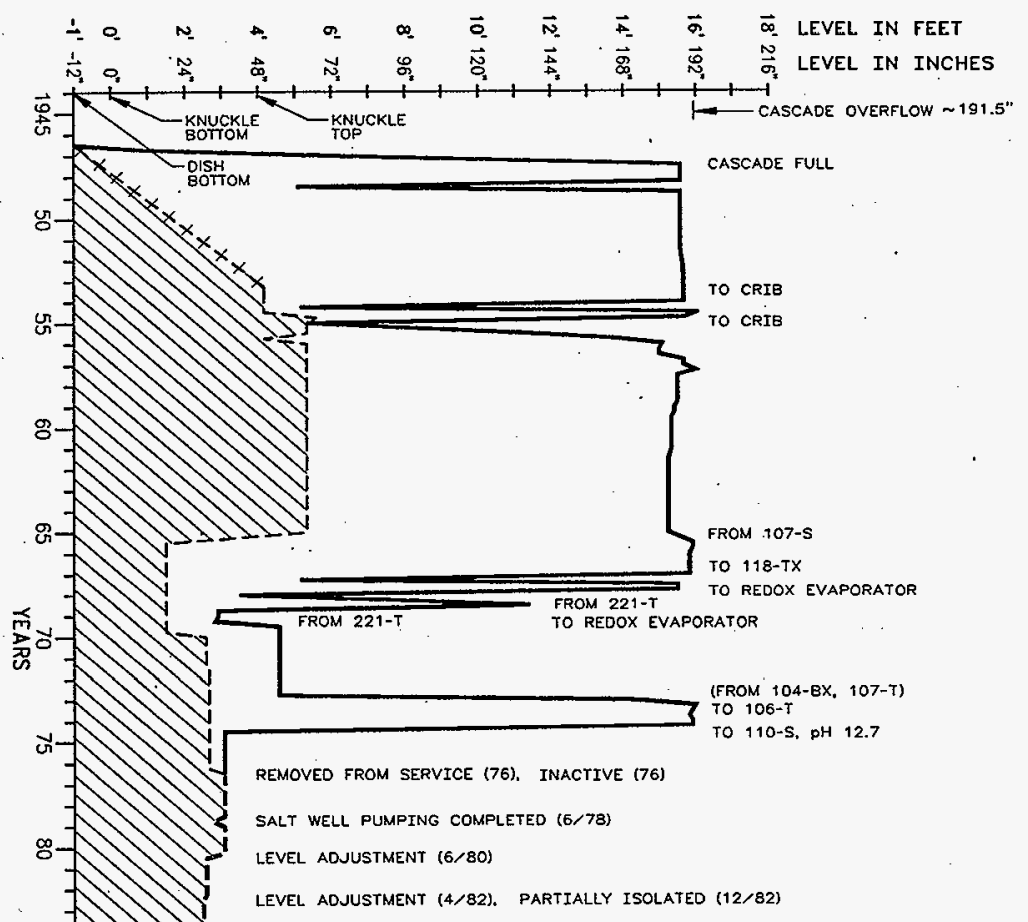

LEVEL ADJUSTMENT (5/87). PHOTOS (5/87). INTERIM STABILIZED $(6 / 87)$

INTRUSION PREVENTION $(9 / 88)$ SEE NOTE 3

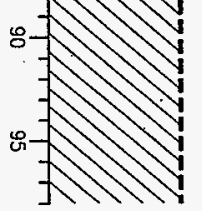

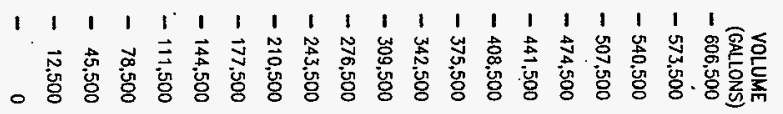


Figure A4-2. Tank 241-T-105 High Temperature Plot.

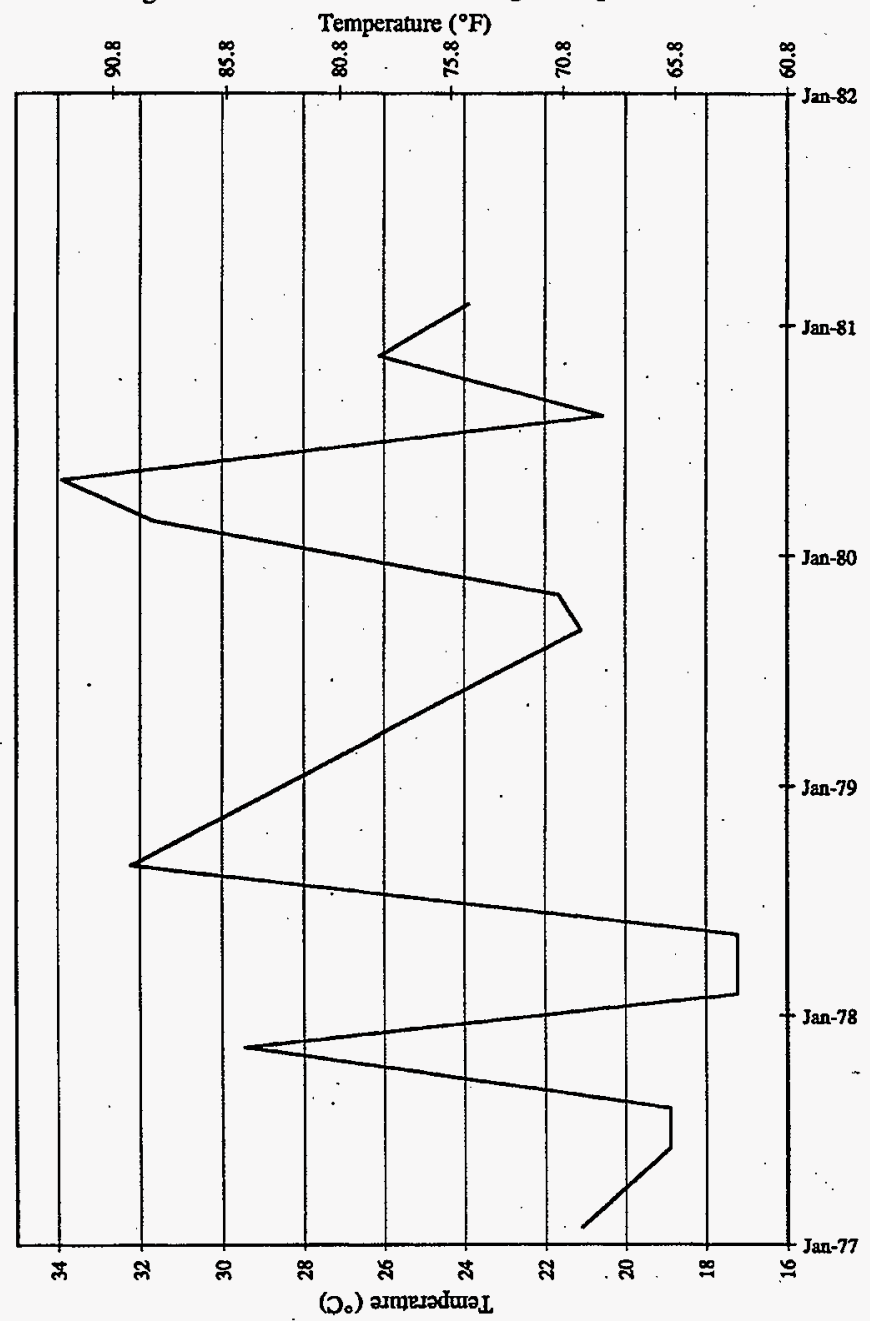




\section{A5.0 APPENDDX A REFERENCES}

Agnew, S. F., J. Boyer, R. A. Corbin, T. B. Duran, J. R. Fitzpatrick, K. A. Jurgensen, T. P. Ortiz, and B. L. Young, 1997a, Hanford Tank Chemical and Radionuclide Inventories: HDW Model Rev. 4, LA-UR-96-3860, Rev. 0, Los Alamos National Laboratory, Los Alamos, New Mexico.

Agnew, S. F., P. Baca, R. A. Corbin, T. B. Duran, and K. A. Jurgensen, 1997b, Waste Status and Transaction Record Summary (WSTRS) Rev. 4, LA-UR-97-311, Rev. 0, Los Alamos National Laboratory, Los Alamos, New Mexico.

Alstad, A. T., 1993, Riser.Configuration Document for Single-Shell Waste Tanks, WHC-SD-WM-RE-TI-053, Rev. 9, Westinghouse Hanford Company, Richland, Washington.

Anderson, J. D., 1990, A History of the 200 Area Tank Farms, WHC-MR-0132, Rev. 0, Westinghouse Hanford Company, Richland, Washington.

Bergmann, L. M., 1991, Single-Shell Tank Isolation Safety Analysis Report, WHC-SD-WM-SAR-006, Rev. 2, Westinghouse Hanford Company, Richland, Washington.

Brevick, C. H., J. L. Stroup, and J. W. Funk, 1997, Supporting Document for the Historical Tank Content Estimate for T Tank Farm, WHC-SD-WM-ER-320, Rev. 1, Westinghouse Hanford Company, Richland, Washington.

Hanlon, B. M., 1998, Waste Tank Summary Report for Month Ending February 28, 1998, HINF-EP-0182-119, Lockheed Martin Hanford Corp. for Fluor Daniel Hanford, Inc., Richland, Washington.

Lipnicki, J., 1997, Waste Tank Risers Available for Sampling, WHC-SD-WM-TI-710, Rev. 4, Lockheed Martin Hanford Corp. for Fluor Daniel Hanford, Inc., Richland, Washington.

Public Law 101-510, 1990, "Safety Measures for Waste Tanks at Hanford Nuclear Reservation," Section 3137 of National Defense Authorization Act for Fiscal Year 1991.

Rogers, R. D., and H. T. Daniels, 1944, Specifications for Construction of Composite Storage Tank Bldg. \#241 at Hanford Engineer Works, CVI-73550, E. I. Dupont de Nemours \& Co., Richland, Washington.

Tran, T. T., 1993, Thermocouple Status Single-Shell and Double-Shell Waste Tanks, WHC-SD-WM-TI-553 Rev. 0, Westinghouse Hanford Company, Richland, Washington. 
Vitro Engineering Corporation, 1988, Piping Waste Tank Isolation 241-T-105, H-2-73062, Rev. 4, Richland, Washington.

Welty, R. K., 1988, Waste Storage Täk Status and Leak Detection Criteria, WHC-SD-WM-TI-356, Rev. 0, Vol. 2, Westinghouse Hanford Company, Richland, Washington. 
This page intentionally left blank. 
HNF-SD-WM-ER-369 Rev: 2

APPENDIX B

SAMPLING OF TANK 241-T-105

B-1 
HNF-SD-WM-ER-369 Rev. 2

This page intentionally left blank. 


\section{APPENDIX B \\ SAMPLING OF TANK 241-T-105}

Appendix B provides sampling and analysis information for each known sampling event for tank 241-T-105 and assesses push core sample results. It includes the following:

- Section B1.0: Tank Sampling Overview

- Section B2.0: Sampling Events

- Section B3.0: Assessment of Characterization Results

- Section B4.0: Appendix B References.

\section{B1.0 TANK SAMPLING OVERVIEW}

This section identifies applicable requirements for the June 1997 and March and May 1993 push mode core sampling and analysis events for tank 241-T-105.

The 1997 push mode core samples were taken to satisfy the requirements of the Tank Safety Screening Data Quality Objective (Dukelow et al. 1995) and the Memorandum of Understanding for the Organic Complexant Safety Issue Data Requirements (Schreiber 1997). Sampling and analyses were performed in accordance with the Tank 241-T-105 Push Mode Sampling and Analysis Plan (Field 1997). For further discussion of the sampling and analysis procedures, refer to the Tank Characterization Reference Guide (DeLorenzo et al. 1994).

The 1993 push mode core sample event predated current DQOs. Recovery for this sample event was poor, and resampling was recommended. Further discussion of this sample event are included in Section B2.2.

A 1974 liquid grab sample is discussed in Section B2.4. 


\section{B2.0 SAMPLING EVENTS}

This section describes the 1997 and 1993 push mode core sampling events. Table B2-1 summarizes the sampling and analytical requirements for the applicable DQOs and issues.

Table B2-1. Integrated Data Quality Objective Requirements for Tank 241-T-105. ${ }^{1}$

\begin{tabular}{|c|c|c|c|}
\hline 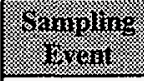 & 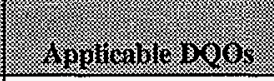 & 5inuitig Requicancit & 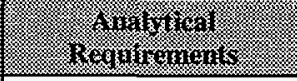 \\
\hline $\begin{array}{l}\text { Push mode } \\
\text { core } \\
\text { sampling }\end{array}$ & $\begin{array}{l}\text { Safety screening } \\
\text { - Energetics } \\
\text { - Moisture content } \\
\text { - Total alpha } \\
\text { - Flammable gas } \\
\text { Dukelow et al. (1995) } \\
\\
\text { Organic complexants } \\
\text { Schreiber (1997) } \\
\\
\text { Organic solvents } \\
\text { Meacham et al. (1997) }\end{array}$ & $\begin{array}{l}\text { Core samples from a } \\
\text { minimum of two risers } \\
\text { separated radially to the } \\
\text { maximum extent possible. } \\
\text { Combustible gas } \\
\text { measurement }\end{array}$ & $\begin{array}{l}\text { Flammability, } \\
\text { energetics, moisture, } \\
\text { total alpha activity, } \\
\text { density, anions, cations, } \\
\text { radionuclides, TOC, } \\
\text { separable organics, } \\
\text { physical properties, TIC, } \\
\text { pH, Cr(VI) }\end{array}$ \\
\hline $\begin{array}{l}\text { Vapor } \\
\text { sampling }\end{array}$ & $\begin{array}{l}\text { Organic Solvents } \\
\text { Meacham et al. (1997) }\end{array}$ & $\begin{array}{l}\text { Steel canisters, triple sorbent } \\
\text { traps, sorbent trap systems }\end{array}$ & $\begin{array}{l}\text { Flammable gas, organic } \\
\text { vapors, permanent gases }\end{array}$ \\
\hline
\end{tabular}

Note:

TIC $=$ total inorganic carbon

'Field (1997)

\section{B2.1 1997 PUSH CORE SAMPLING EVENT}

Two push mode core samples were collected from tank 241-T-105 in 1997. Core 205 was collected from riser 3 on June 24 and 26, 1997. Core 207 was collected from riser 7 on June 27 and June 30, 1997. Two segments were retrieved for each core.

Sampling satisfied the safety screening DQO and organic complexants memorandum of understanding. Analyses included total alpha to determine criticality, DSC to ascertain the fuel energy value, thermogravimetric analysis (TGA) to obtain the total moisture content, and bulk density. In addition, combustible gas meter readings in the tank headspace were performed to measure flammability. Inductively coupled plasma spectroscopy (ICP) and ion 
chromatography (IC) analyses were conducted to assess the potential contamination by hydrostatic head fluid used during sampling. Opportunistic ICP and IC analytes were also reported.

The core samples were obtained by a core sampling truck with sampling equipment mounted on a rotating platform. A drill string containing a stainless steel sampler was used to collect the waste. The sampler obtained a $48 \mathrm{~cm}$ (19 in.) long and $2.5 \mathrm{~cm}$ (1 in.) diameter segment of the waste. After the sampler was filled, it was extracted from the drill string and sealed within a stainless steel liner to trap any liquid which might leak from the sampler. The liner was inserted into a lead-shielded shipping cask before being transferred to the 222-S Laboratory for analysis. Chain-of-custody forms were completed for each segment. A lithium bromide tracer fluid was used as a hydrostatic head fluid during sampling.

\section{B2.1.1 Sample Handling}

Core 205 and 207 samples were received by the 222-S Laboratory on June 26 and July 1 , 1997, respectively. The samples were transported to the laboratory within four calendar days from the time each segment was removed from the tank.

The valve was half open on the sampler for core 205 , segment 2 . This may have caused the poor recovery for this segment. Segment 2 of core 205 and segment 1 of core 207 contained $0.5 \mathrm{~cm}(0.25 \mathrm{in}$.) chunks of gravel-like material. Table B2-2 provides a description and the characteristics of the two segment core samples. 
Table B2-2. Tank 241-T-105 Subsampling Scheme and Sample Description. ${ }^{1}$

\begin{tabular}{|c|c|c|c|c|}
\hline Segri: & (S) & (granis: & 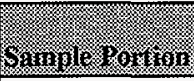 & 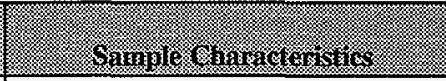 \\
\hline $205: 1$ & 205-01 & 292 & Drainable liquid & $\begin{array}{l}290 \mathrm{~mL} \text { of black opaque liquid. } \\
\text { A trace amount of crystalline solid } \\
\text { material. No organic layer was } \\
\text { observed. LiBr head fluid was added } \\
\text { to drill string. }\end{array}$ \\
\hline \multirow[t]{2}{*}{$205: 2$} & \multirow[t]{2}{*}{ 205-02 } & $\begin{array}{l}81.0 \text { liner liquid } \\
41.0 \text { drainable }\end{array}$ & Drainable liquid & \multirow{2}{*}{$\begin{array}{l}\text { Valve was half open. } 80 \mathrm{~mL} \text { black } \\
\text { opaque liner liquid. } 35 \mathrm{~mL} \text { drainable } \\
\text { liquid. Solids were } 1 / 4 \text { to } 1 / 2 \text { in. hard } \\
\text { crystalline material coated by black } \\
\text { sludge slurry. Some crystals were } \\
\text { clear others were dark gray, like } \\
\text { cement. Pieces could not be broken } \\
\text { with a spatula. No organic layer was } \\
\text { observed. }\end{array}$} \\
\hline & & 81.6 & Lower half & \\
\hline \multirow[t]{2}{*}{$207: 1$} & \multirow[t]{2}{*}{$207-01$} & 184 & Drainable liquid & \multirow{2}{*}{$\begin{array}{l}160 \mathrm{~mL} \text { black opaque liquid, }<5 \mathrm{~mL} \\
\text { liner liquid. Solids black, granular } \\
\text { slurry. No organic layer was } \\
\text { observed. } 1,500 \mathrm{~mL} \mathrm{LiBr} \text { added to } \\
\text { drill string. }\end{array}$} \\
\hline & & 72.3 & Lower half & \\
\hline \multirow[t]{2}{*}{$207: 2$} & \multirow[t]{2}{*}{$207-02$} & 177 & Upper half & \multirow{2}{*}{$\begin{array}{l}20 \mathrm{~mL} \text { light brown, opaque liner } \\
\text { liquid, no drainable liquid. Solids } \\
\text { light to dark brown, smooth textured } \\
\text { sludge slurry. Lower half solids held } \\
\text { shape. } 1,500 \mathrm{~mL} \mathrm{LiBr} \text { added to drill } \\
\text { string. }\end{array}$} \\
\hline & & 198 & Lower half & \\
\hline
\end{tabular}

Note:

${ }^{1}$ Esch (1997)

\section{B2.1.2 Sample Analysis}

The analyses performed on the push core samples were limited to those required by the safety screening DQO and organic complexants memorandum of understanding. Analyses included DSC for thermal properties, TGA for percent water, total alpha, and bulk density. The safety screening DQO also required ICP and IC analyses for lithium and bromide tracer elements, to assess the potential for hydrostatic head fluid contamination. Other ICP and IC analytes were also reported as "opportunistic" analytes (Field 1997). Total organic carbon analyses were not conducted because no exothermic activity was found in any sample. 
Drainable liquid was filtered before analysis. Filtered sludge from core 205, segment 2 drainable liquid was analyzed separately. The amount of sludge recovered was insufficient for sludge analyses on other samples.

The clear and dark crystals observed in the samples (see Table B2-2) were analyzed separately as much as possible. However, the two types of crystalline material could not be completely separated from each other or from sludge coatings. Consequently, reanalyses were not performed for high relative percent differences (RPDs). Because this material was very hard and could not be homogenized, only IC and ICP analyses were performed on this material for characterization purposes (Field 1997). Small pieces, $0.2 \mathrm{~g}$ to $0.6 \mathrm{~g}$ each, were subsampled to perform a water digest for IC analysis and an acid digest for ICP analysis.

All reported analyses were performed according to approved laboratory procedures (see Table B2-3). Table B2-4 is a summary of the sample portions, sample numbers, and analyses performed on each sample.

Table B2-3. Analytical Procedures ${ }^{1}$.

\begin{tabular}{|c|c|c|}
\hline $3 \ln 160$ & 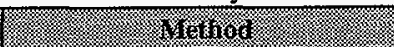 & 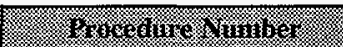 \\
\hline Energetics & Differential scanning calorimetry & LA-514-114 \\
\hline Percent water & Thermogravimetric analysis & LA-514-114 \\
\hline Total alpha activity & Alpha proportional counter & LA-508-101 \\
\hline Flammable gas & Combustible gas analyzer & $\begin{array}{l}\text { WHC-IP-0030 IH } 1.4 \\
\text { and IH-2.1 }\end{array}$ \\
\hline Metals by ICP/AES & $\begin{array}{l}\text { Inductively coupled plasma } \\
\text { spectrometry }\end{array}$ & \begin{tabular}{|l} 
LA-505-151 \\
LA-505-161 \\
\end{tabular} \\
\hline Anions by IC & Ion chromatography & LA-533-105 \\
\hline Bulk density & Gravimetry & LO-160-103 \\
\hline Specific gravity & Gravimetry & LA-510-112 \\
\hline
\end{tabular}

Notes:

AES = atomic emission spectroscopy

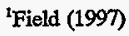

${ }^{2}$ Safety Department Administrative Manuals, Westinghouse Hanford Company, Richland, Washington: IH 1.4, Industrial Hygiene Direct Reading Instrument Survey IH 2.1, Standard Operating Procedure, MSA Model 260 Combustible Gas and Oxygen Anslyzer 
Table B2-4. Sample Analyses Summary. ${ }^{1}$ (2 sheets)

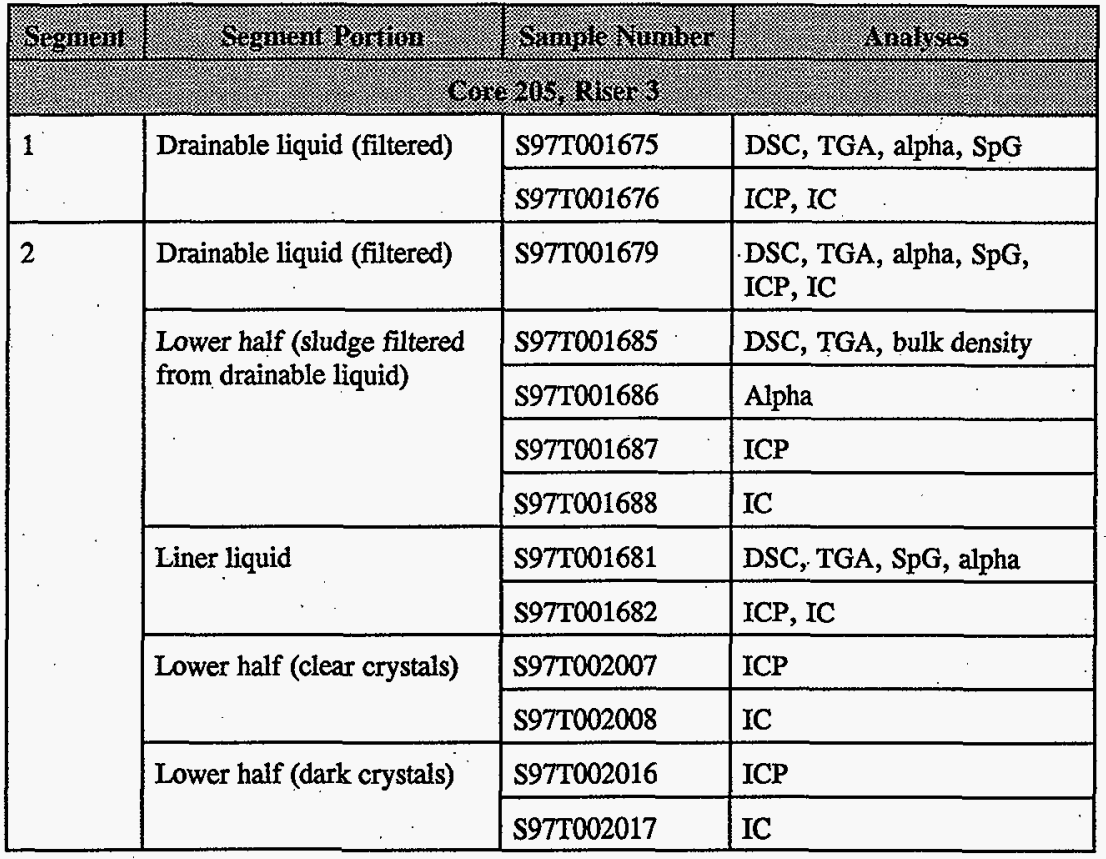


Table B2-4. Sample Analyses Summary. ${ }^{1}$ (2 sheets)

\begin{tabular}{|c|c|c|c|}
\hline Gegrineir & 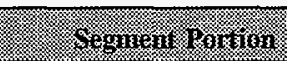 & Srmul viminer & Vinatives \\
\hline & & 10\% & \\
\hline \multirow[t]{7}{*}{1} & \multirow[t]{2}{*}{ Drainable liquid } & S97T001691 & DSC, TGA, SpG, alpha \\
\hline & & S97T001692 & $\mathrm{ICP}, \mathrm{IC}$ \\
\hline & \multirow[t]{5}{*}{ Lower half } & S97T001695 & Bulk density \\
\hline & & S97T001697 & DSC, TGA \\
\hline & & S97T001698 & Alpha. \\
\hline & & S97T001699 & ICP \\
\hline & & S97T001700 & IC \\
\hline \multirow[t]{11}{*}{2} & \multirow[t]{5}{*}{ Lower half } & S97T001703 & DSC, TGA \\
\hline & & S97T001702 & Bulk density \\
\hline & & S97T001704 & Alpha \\
\hline & & S97T001705 & ICP \\
\hline & & S97T001706 & IC \\
\hline & \multirow[t]{5}{*}{ Upper half } & S97T001709 & DSC, TGA \\
\hline & & S97T001708 & Bulk density \\
\hline & & S97T001711 & Alpha \\
\hline & & S97T001712 & ICP \\
\hline & & S97T001713 & IC \\
\hline & Liner liquid & S97T001696 & ICP, IC \\
\hline
\end{tabular}

Notes:

$\mathrm{SpG}=$ specific gravity

${ }^{1}$ Esch (1997) 


\section{B2.1.3 Analytical Results}

This section summarizes the sampling and analytical results associated with the June 1997 sampling and analysis of tank 241-T-105. Table B2-5 shows the location of analytical results included in this report. These results are documented in Esch (1997).

Table B2-5. Analytical Tables.

\begin{tabular}{|c|c|}
\hline $2.1 .18,8$ & Table Nunler \\
\hline Total alpha activity & $B 2-60$ \\
\hline Percent water & B2-58 \\
\hline Summary data for metals by ICP & B2-12 to $B 2-48$ \\
\hline Anions by IC & $\mathrm{B} 2-49$ to $\mathrm{B} 2-56$ \\
\hline Bulk density & B2-57 \\
\hline Specific gravity & B2-59 \\
\hline
\end{tabular}

The quality control (QC) parameters assessed in conjunction with tank 241-T-105 samples were standard recoveries, spike recoveries, duplicate analyses (RPDs), and blanks. The QC criteria are specified in the SAP (Field 1997). The limits for blanks are set forth in guidelines followed by the laboratory, and all data results in this report have met those guidelines. Sample and duplicate pairs, in which any QC parameter was outside these limits, are footnoted in the sample mean column of the following data summary tables with an a, b, c, d, e, f, g, and $\mathrm{h}$ :

- " $\mathrm{a}$ " indicates the standard recovery was below the $\mathrm{QC}$ limit

- . " $b$ " indicates the standard recovery was above the QC limit

- " $\mathrm{c}$ " indicates the spike recovery was below the QC limit

- " $\mathrm{d}$ " indicates the spike recovery was above the QC limit

- " $\mathrm{e}$ " indicates the RPD was above the QC limit

- " $\mathrm{f}$ " indicates blank contamination

- " $\mathrm{g}$ " indicates this is a tentatively identified compound

- " $h$ " indicates the serial dilution exceeds the acceptance limit.

In the analytical tables in this section, the "mean" is the average of result and duplicate values. All values, including those below the detection level (denoted by " $<$ "), were averaged. If both sample and duplicate values were nondetected, or if one value was detected and the other was not, the mean is expressed as a nondetected value. If both values were detected, the mean is expressed as a detected value. 
B2.1.3.1 Total Alpha Activity. Analyses for total alpha activity were performed on the samples recovered from tank 241-T-105. Solids samples were prepared by fusion digestion. Two fusions were prepared for each sample (for duplicate results). Each fused dilution was analyzed twice, and the results were averaged and reported as one value. Direct analyses were performed on drainable liquid samples. The highest result returned was $0.587 \mu \mathrm{Ci} / \mathrm{g}$.

B2.1.3.2 Thermogravimetric Analysis. Thermogravimetric analysis measures the mass of a sample as its temperature is increased at a constant rate. Nitrogen is passed over the sample during heating to remove any released gases. A decrease in the weight of a sample during TGA represents a loss of gaseous matter from the sample, through evaporation or through a reaction that forms gas phase products. The moisture content is estimated by assuming that all TGA sample weight loss up to a certain temperature (typically 150 to $20{ }^{\circ} \mathrm{C}$ ) is caused by water evaporation. The temperature limit for moisture loss is chosen by the operator at an inflection point on the TGA plot. Other volatile matter fractions can also be differentiated by inflection points.

The percent water for tank 241-T-105 solids samples ranged from 49.2 to 71.7 percent by weight.

B2.1.3.3 Differential Scanning Calorimetry. In a DSC analysis, heat absorbed or emitted by a substance is measured while the sample is heated at a constant rate. Nitrogen is passed over the sample material to remove any gases being released. The onset temperature for an endothermic or exothermic event is determined graphically.

No exothermic reactions were observed; therefore, an upper limit of a 95 percent confidence interval on the mean for each sample was not calculated.

B2.1.3.4 Inductively Coupled Plasma. Samples were prepared by fusion or acid digest. Although a full suite of analytes were reported, only lithium was specifically requested for the safety screening DQO. The primary ICP analyte detected was sodium. Other analytes at concentrations above $1,000 \mu \mathrm{g} / \mathrm{g}$ included aluminum, bismuth, iron, manganese, phosphorous, silicon, sulfur and uranium.

Lithium results were low or below detection levels for most samples. Lithium was found at $>1,000 \mu \mathrm{g} / \mathrm{mL}$ in core 207, segment 2 liner liquid samples, indicating the liner liquid was at least partly hydrostatic head fluid. However, no drainable liquid was observed in core 207, segment 2 , and lithium values for solids were $<100 \mu \mathrm{g} / \mathrm{g}$.

B2.1.3.5 Ion Chromatography. Samples were prepared by water digest. Although a full suite of analytes was reported, only bromide was requested for the safety screening DQO. The primary ICP analytes were nitrate and nitrite. Oxalate, fluoride, phosphate, and sulfate were observed at $>1,000 \mu \mathrm{g} / \mathrm{g}$. 
High concentrations of bromide $(>20,000 \mu \mathrm{g} / \mathrm{mL})$ were found in core 207, segment 2 liner liquid, indicating the liner liquid was mostly hydrostatic head fluid. However, bromide values were $<1,030 \mu \mathrm{g} / \mathrm{g}$ for solids; therefore, the impact of hydrostatic head fluid intrusion into the samples was negligible.

B2.1.3.6 Specific Gravity and Bulk Density. Bulk density was performed on core 205 filtered sludge samples and on core 207 samples. The results for core 207 samples ranged from 1.32 to $1.53 \mathrm{~g} / \mathrm{mL}$. The bulk density of the filtered sludge was $1.34 \mathrm{~g} / \mathrm{mL}$. An average solids density of 1.45 was used to calculate the solids total alpha activity action limit and analyte inventories for the tank. The average specific gravity for the drainable liquids was 1.185 with values ranging from 1.17 to 1.2 .

B2.1.3.7 Crystal Composition. The clear crystalline material dissolved readily in $\mathrm{HNO}_{3}$ and $\mathrm{HCl}$ acid. Approximately 80 to 90 percent of the crystalline material dissolved in water alone. Analytes found in this material indicated that the crystals may be sodium fluoride diphosphate. The darker, cement-like crystals did not dissolve as well. Approximately 75 percent dissolved in the acid, leaving white powdery undissolved solids. Very little of the material dissolved in the deionized water (Esch 1997).

\section{B2.2 1993 PUSH CORE SAMPLING EVENT}

Two push mode core samples were collected from tank 241-T-105 in 1993. Cores 53 and 54 were collected on March 19 and 24 from risers 8 and 2, respectively. The field blank was collected on March 22, 1993. These cores were transported to the Westinghouse Hanford Company 222-S Laboratory for chemical analyses. Portions of core 54 were sent to the Pacific Northwest National Laboratory 325 Laboratory. Core 57 samples were collected on May 28, 1993 from riser 5 to support the core sampling restart effort. Both segments were sent to the 325 Laboratory for physical tests.

The core samples were obtained by a core sampling truck with sampling equipment mounted on a rotating platform. A drill string containing a stainless steel sampler was used to collect the waste. The sampler obtained a $48 \mathrm{~cm}$ (19 in.) long and $2.5 \mathrm{~cm}$ (1 in.) diameter segment of the waste. After the sampler was filled, it was extracted from the drill string and sealed within a stainless steel liner to trap any liquid which might leak from the sampler. The liner was inserted into a lead-shielded shipping cask before being transferred to the laboratories. Chain-of-custody forms were completed for each segment.

Water was used as hydrostatic head fluid for core 54. 


\section{B2.2.1 Sample Handling}

Core samples 53 and 54 were received by the 222-S Laboratory from March 22, 1993, to March 29, 1993, without preservation (no acidification or refrigeration). The 325 Laboratory received core 57 and aliquots from core 54 on June 14, 1993, without preservation. Fach core consisted of two segments. The segments were a mixture of liquids and solids. Sample recovery ranged from 8 to 91 percent.

Table B2-6 shows the subsampling scheme and descriptions for the sample extrusions (Kocher 1994 and Giamberardini 1993). Sample recovery was generally poor for this sample event. After the event, an investigation of riser 8 (core 53 samples) showed a bend in the riser that probably contributed to poor sample recovery.

Table B2-6. Tank 241-T-105 Subsampling Scheme and Sample Description. ${ }^{1}$

\begin{tabular}{|c|c|c|c|c|}
\hline 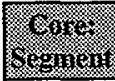 & (8) & 1 (1) & s.minis: & 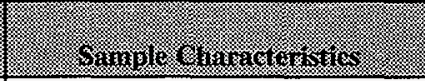 \\
\hline $53: 1$ & $93-005$ & $\begin{array}{l}29.8 \text { solids } \\
11.3 \text { liner liquid }\end{array}$ & $\begin{array}{l}\text { Homogenized } \\
\text { sample }\end{array}$ & $\begin{array}{l}33.7 \mathrm{~mL} \text { of homogeneous, brown, } \\
\text { muddy (like soft wet clay) solids. } \\
\text { No drainable liquid. Poor } \\
\text { recovery, clear liner liquid. }\end{array}$ \\
\hline $53: 2$ & $93-006$ & $\begin{array}{l}11.2 \text { liner liquid } \\
97.6 \text { drainable liquid, } \\
\text { trace solids }\end{array}$ & Homogenized & $\begin{array}{l}85 \mathrm{~mL} \text { drainable liquid, poor } \\
\text { recovery. }\end{array}$ \\
\hline $54: 1$ & 93-007 & $\begin{array}{l}117 \text { solids } \\
13.8 \text { drainable liquid } \\
5 \text { liner liquid }\end{array}$ & Homogenized & $\begin{array}{l}58 \mathrm{~mL} \text { dark brown to white solids, } \\
\text { smooth and wet, nonhomogeneous, } \\
9 \mathrm{~mL} \text { drainable liquid, poor } \\
\text { recovery. }\end{array}$ \\
\hline $54: 2$ & $93-008$ & $165 \mathrm{~g}$ drainable liquid & Homogenized & $170 \mathrm{~mL}$ drainable liquid, no solids. \\
\hline 57:1. & $93-011$ & 16.4 solids & Homogenized & $\begin{array}{l}1.5 \text { in dark brown solids, cohesive, } \\
\text { dry, homogeneous. No liquid. No } \\
\text { subsampling. Poor recovery. }\end{array}$ \\
\hline $57: 2$ & $93-012$ & $16 \mathrm{~g}$ solids & Homogenized & $\begin{array}{l}1.5 \text { in cream and dark brown solids, } \\
\text { runny and soft liquid. } \\
\text { Heterogeneous sample. No } \\
\text { drainable liquid. No subsampling. } \\
\text { Poor recovery. }\end{array}$ \\
\hline
\end{tabular}




\section{B2.2.2 Sample Analysis}

An extensive set of analyses were required by Bell (1993), including tests for chemical, physical, rheological, and thermodynamic properties. This section discusses the analyses used to characterize the waste in tank 241-T-105.

Cores 53 and 54 contained more liquid and fewer solids than expected. Because the amount of solids was not sufficient to perform all analyses required in Bell (1993), the analyses were prioritized in Silvers and Sasaki (1993). The imbalance in analytical results between the two cores was caused because the sample ran out. The liquids from core 53 were analyzed as outlined in Bell (1993). Only limited analyses were performed on the liquids from core 54, because the liquid was believed to be water used as a hydrostatic head fluid during sampling (Silvers and Sasaki 1993). No core composites were made for either core because of the lack of sample. Similarly, no composites were made for core 57.

A homogenization test was performed on segment 1 of core 54. The homogenization test involved analyzing samples taken from two different areas of a homogenized sample to see whether significant differences occurred between the two areas. A discrepancy exists between the laboratory case narrative in Kocher (1994) and the labels in the data tables in Kocher (1994) about the analyses that were performed. The laboratory narrative states that the analyses used in the testing were ICP, gamma energy analysis (GEA), and total alpha; and that homogenization test analyses were made on the acid digest for each subsample (sample numbers starting with 40- and 41-). Although laboratory data tables indicate otherwise, the narrative indicates that all other analyses were conducted on whole solids samples or drainable liquid samples (Kocher 1995).

Table B2-7 shows the analyses that were performed on the solids of each segment, including the homogenization test analyses. Analyses were performed at the 222-S Laboratory and 325 Laboratory as specified in Table B2-7. Table B2-8 shows the analyses that were performed on the drainable liquid from each segment. Table B2-9 lists the procedures used for inorganic and radiological analyses. Table B2-10 lists procedures for physical and rheological analyses. 
Table B2-7. Analyses Performed on the Solids (by Segment). (2 sheets)

\begin{tabular}{|c|c|c|c|c|}
\hline & & & (4) & \\
\hline 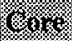 & (6) & (9iolings & 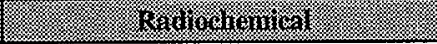 & 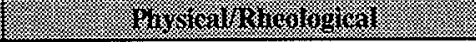 \\
\hline 53 & 1 & & & DSC, TGA, particle size \\
\hline 54 & 1 & $\mathrm{TOC}^{1}, \mathrm{TIC}^{1}$ & Mass spectrometry ${ }^{1}$, total alpha $\mathrm{Pu}^{1}$ & wt\% solids (gravimetry) ${ }^{1}$, particle size \\
\hline 57 & $1^{1}$ & -- & -- & $\begin{array}{l}\text { DSC, TGA, wt\% solids (gravimetry), } \\
\text { density, centrifuged solids density, } \\
\text { centrifuged supernatant density, vol\% } \\
\text { settled solids, vol\% centrifuged solids, } \\
\text { consistency factor, yield point, flow } \\
\text { behavior index, wt\% centrifuged solids. }\end{array}$ \\
\hline 57 & $2^{1}$ & TIC & $-\cdots$ & $\begin{array}{l}\text { DSC, TGA, wt\% solids (gravimetry), } \\
\text { density, vol\% settled solids, volume \% } \\
\text { centrifuged solids. }\end{array}$ \\
\hline & & (1) - & 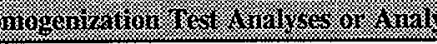 & \\
\hline 53 & 2 & $\begin{array}{l}\mathrm{Hg}, \mathrm{Cr}^{+6}, \mathrm{CN}^{*}, \mathrm{OH}^{-}, \mathrm{NO}_{2}^{-} \text {, } \\
\mathrm{IC}, \mathrm{TOC}, \mathrm{TIC}, \\
\mathrm{ICP} \text { (acid, water, fusion) } \\
\text { AA for Cs (acid; fusion), }\end{array}$ & $\begin{array}{l}\text { GEA (fusion; water), GEA (residual } \\
\text { solids), total alpha (fusion; water), } \\
\text { total beta (fusion; water) } \\
\mathrm{U}^{241} \mathrm{Am},{ }^{99} \mathrm{Tc},{ }^{90} \mathrm{Sr},{ }^{239240} \mathrm{Pu},{ }^{14} \mathrm{C} \text {, } \\
\text { tritium }\end{array}$ & pH, total dissolved solids \\
\hline
\end{tabular}


Table B2-7. Analyses Performed on the Solids (by Segment). (2 sheets)

\begin{tabular}{|c|c|c|c|c|}
\hline & & 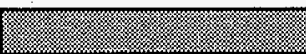 & Aind) & \\
\hline (6r) & S.8.8n & 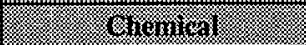 & 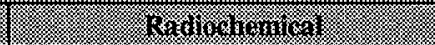 & Thu sicumaterlogica! \\
\hline 54 & 1 & 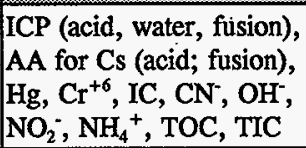 & $\begin{array}{l}\text { GEA (fusion; water), GEA (residual } \\
\text { solids), total alpha (fusion; water), } \\
\text { total beta (fusion; water), tritium, } \\
{ }^{241} \mathrm{Am},{ }^{14} \mathrm{C},{ }^{239240} \mathrm{Pu},{ }^{90} \mathrm{Sr},{ }^{99} \mathrm{Tc}, \mathrm{U}\end{array}$ & $\begin{array}{l}\mathrm{pH} \text {, total dissolved solids, wt\% solids } \\
\text { (gravimetry), wt\% residual solids }\end{array}$ \\
\hline
\end{tabular}

Notes:

vol\% $=$ vohume percent

'Analyses were performed at the 325 Laboratory at Pacific Northwest National Laboratory; all others were performed at the 222-S Laboratory.

${ }^{2}$ As discussed in Section B1.3, the analyses listed as homogenization test analyses in this table are those listed as such in the data tables from the laboratory data package (Kocher 1994). 
Table B2-8. Analyses Performed on the Drainable Liquid (by Segment).

\begin{tabular}{|c|c|c|c|c|}
\hline \multirow[b]{2}{*}{808} & \multirow[b]{2}{*}{ 6.8.1. } & \multicolumn{3}{|c|}{ 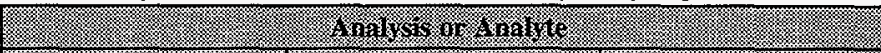 } \\
\hline & & (1) Chenimal: & Padirgengninerl & 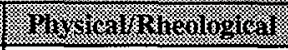 \\
\hline 53 & 2 & $\begin{array}{l}\mathrm{IC}, \mathrm{OH}^{-}, \mathrm{NH}_{4}^{+}, \mathrm{NO}_{2}^{-} \text {, } \\
\text { TOC, TIC }\end{array}$ & $\begin{array}{l}\text { Total alpha, total beta, } \\
{ }^{241} \mathrm{Am},{ }^{238} \mathrm{Pu},{ }^{2391240} \mathrm{Pu}, \\
{ }^{90} \mathrm{Sr},{ }^{99} \mathrm{Tc}, \mathrm{U}\end{array}$ & $\begin{array}{l}\text { DSC, TGA, specific } \\
\text { gravity, } \mathrm{pH}\end{array}$ \\
\hline 54 & 2 & $\mathrm{IC}$ & -- & $\begin{array}{l}\text { DSC, TGA, specific } \\
\text { gravity, } \mathrm{pH}\end{array}$ \\
\hline
\end{tabular}

Table B2-9. Inorganic and Radiochemical Analytical Methods. ${ }^{1}$ (2 sheets)

\begin{tabular}{|c|c|c|}
\hline 6ran & (3) & Vocedinge \\
\hline Total metals & ICP spectrometry & LA-505-151 \\
\hline $\mathrm{Cr}(\mathrm{VI})$ & Spectrophotometry & LA-265-101 \\
\hline $\mathrm{Hg}$ & Cold vapor atomic absorption & LA-325-104 \\
\hline $\mathrm{F}, \mathrm{Cl}, \mathrm{NO}_{3}^{-}, \mathrm{NO}_{2}^{-}, \mathrm{PO}_{4}{ }^{3-}, \mathrm{SO}_{4}{ }^{2-}$ & IC & LA-533-105 \\
\hline $\mathrm{NO}_{2}^{-}$ & Absorbance spectrometry & LA-645-001 \\
\hline $\mathrm{OH}^{-}$ & Potentiometric titration & LA-661-105 \\
\hline Total organic carbon & Coulometry & \begin{tabular}{|l|} 
LA-622-102/ \\
PNL-ALO-381 \\
\end{tabular} \\
\hline Total inorganic carbon & Coulometry & \begin{tabular}{|l|} 
LA-344-105/ \\
PNL-ALO-381
\end{tabular} \\
\hline $\mathrm{CN}^{-}$ & Distillation/spectrometry & $\begin{array}{l}\text { LA-695-101/ } \\
\text { LA-695-102 }\end{array}$ \\
\hline $\mathrm{NH}_{3}$ & Distillation/titration & LA-634-102 \\
\hline Total uranium & Laser fluorimetry & LA-925-106 \\
\hline Total alpha & Alpha proportional counting & LA-508-104 \\
\hline Total beta & Beta proportional counting & $\begin{array}{l}\text { LA-508-101 } \\
\text { LA-508-052 } \\
\text { LA-504-101 }\end{array}$ \\
\hline${ }^{137} \mathrm{Cs},{ }^{60} \mathrm{Co},{ }^{241} \mathrm{Am}$ & GEA & LA-548-121 \\
\hline Isotopic uranium, plutonium & Mass spectrometry & PNL-ALO-455 \\
\hline${ }^{239 / 240} \mathrm{Pu},{ }^{241} \mathrm{Am}$ & Alpha spectrometry & $\begin{array}{l}\text { LA-503-156 } \\
\text { LA-508-051 } \\
\text { PNL-ALO-423/421 }\end{array}$ \\
\hline
\end{tabular}


Table B2-9. Inorganic and Radiochemical Analytical Methods." (2 sheets)

\begin{tabular}{|l|l|l|}
\hline${ }^{90} \mathrm{Sr}$ & $\begin{array}{l}\text { Extraction/beta proportional } \\
\text { counting }\end{array}$ & LA-220-101 \\
\hline${ }^{99} \mathrm{Tc}$ & Liquid scintillation counting & LA-438-101 \\
\hline${ }^{14} \mathrm{C}$ & Liquid scintillation counting & LA-348-104 \\
\hline${ }^{3} \mathrm{H}$ & Liquid scintillation counting & LA-218-113 \\
\hline $\mathrm{pH}$ & Direct & $\begin{array}{l}\text { LA-212-103 solids } \\
\text { LA-212-102 liquids }\end{array}$ \\
\hline Cesium & Atomic absorption & LA-505-121 \\
LA-505-122
\end{tabular}

Note:

${ }^{1}$ Kocher 1994

Table B2-10. Physical and Rheological Analytical Methods.

\begin{tabular}{|l|l|l|}
\hline Thermal properties & $\begin{array}{l}\text { Thermogravimetric analysis/ } \\
\text { Differential scanning calorimetry }\end{array}$ & $\begin{array}{l}\text { LA-561-112/ } \\
\text { LA-514-113 }\end{array}$ \\
\hline$\%$ water/total dissolved solids & Gravimetric analysis & $\begin{array}{l}\text { LA-564-101/ } \\
\text { PNL-ALO-504 }\end{array}$ \\
\hline Specific gravity & Direct & LA-510-112 \\
\hline Density & Direct & PNL-ALO-501 \\
\hline Rheology & Direct & PNL-ALO-501 \\
& PNL-ALO-502 \\
\hline Particle size & Direct & 599-2-50.3 \\
\hline
\end{tabular}

\section{B2.2.3 Analytical Results}

This section summarizes the sampling and analytical results associated with the March 1993 sampling and analysis of tank 241-T-105. Table B2-11 shows the location of analytical results included in this report. These results are documented in Kocher (1993) and Giamberardini ' (1993). 
Table B2-11. Analytical Data Presentation Tables.

\begin{tabular}{|l|l|}
\hline Cesium by atomic absorption spectroscopy & \\
\hline Mercury by cold vapor atomic absorption spectroscopy & $\mathrm{B} 2-61$ \\
\hline Metals by ICP spectroscopy & $\mathrm{B} 2-62$ \\
\hline Total uranium by laser fluorimetry & $\mathrm{B} 2-63$ through $\mathrm{B} 2-93$ \\
\hline Hexavalent chromium by spectrophotometry & $\mathrm{B} 2-94$ \\
\hline Ammonia by distillation/titration & $\mathrm{B} 2-95$ \\
\hline pH & $\mathrm{B} 2-96$ \\
\hline Anions by IC & $\mathrm{B} 2-97$ \\
\hline Hydroxide by potentiometric titration & $\mathrm{B} 2-98$ through $\mathrm{B} 2-103$ \\
\hline Cyanide by distillation/spectrometry & $\mathrm{B} 2-104$ \\
\hline Nitrite by spectrophotometry & $\mathrm{B} 2-105$ \\
\hline Analyses for total carbon/TOC/TIC & $\mathrm{B} 2-106$ \\
\hline Radionuclides by mass spectroscopy & $\mathrm{B} 2-107$ through $\mathrm{B} 2-110$ \\
\hline Radionuclides by alpha proportional counting & $\mathrm{B} 2-111$ through $\mathrm{B} 2-119$ \\
\hline Radionuclides by alpha spectroscopy & $\mathrm{B} 2-120$ \\
\hline Radionuclides by beta proportional counting & $\mathrm{B} 2-121$ through $\mathrm{B} 2-124$ \\
\hline Radionuclides by GEA & $\mathrm{B} 2-125$ and B2-126 \\
\hline Radionuclides by liquid scintillation counting & $\mathrm{B} 2-127$ through B2-138 \\
\hline Analysis for physical properties & $\mathrm{B} 2-139$ through $\mathrm{B} 2-141$ \\
\hline Analysis for DSC & $\mathrm{B} 2-142$ through $\mathrm{B} 2-154$ \\
\hline Analysis for thermogravimetric properties & $\mathrm{B} 2-155$ \\
\hline & $\mathrm{B} 2-156$ \\
\hline & \\
\hline
\end{tabular}

The QC parameters assessed in conjunction with the 1993 tank 241-T-105 samples included standard recoveries, spike recoveries, and duplicate analyses (RPDs). The QC criteria specified in the Tank Waste Remediation System Tank Waste Characterization Plan (Bell 1993) were 90 to 110 percent recovery for standards, 80 to 120 percent recovery for spikes, and $\leq 20$ percent for RPDs. These criteria applied to all analytes. Sample and duplicate pairs, in which any of these three QC parameters were outside of their limits, are footnoted in the sample mean column of the following data summary tables with an a, b, c, d, or e as follows:

- " $\mathrm{a}$ " indicates the standard recovery was below the QC limit

- $\quad$ "b" indicates the standard recovery was above the QC limit

- $\quad$ " $\mathrm{c}$ " indicates the spike recovery was below the $\mathrm{QC}$ limit 
- $\quad$ " $d$ " indicates the spike recovery was above the QC limit

- $\quad e^{\prime \prime}$ indicates the RPD was greater than the QC limit.

In the analytical tables in this section, the "mean" is the average of the result and duplicate value. All values, including those below the detection level (denoted by " $<$ ") were averaged. If both sample and duplicate values were nondetected, or if one value was detected and the other was not, the mean is expressed as a nondetected value. If both values were detected, the mean is expressed as a detected value.

Blanks were prepared and analyzed with the sample analyses. Bell (1993) established a limit for blank concentration of $\leq 20$ percent of the sample value. No contamination greater than the established limit was discovered in any sample. Therefore, no footnoting of the data tables in Section B2.0 was needed.

B2.2.3.1 Atomic Absorption Spectroscopy. Cesium analysis was performed on fusion and acid digestions of the solid homogenization samples. The results were below the detection limits.

B2.2.3.2 Cold Vapor Atomic Absorption Spectroscopy. Mercury concentration in the samples was measured using cold vapor atomic absorption spectroscopy on the direct solids on cores 53 and 54. Results ranged from 10.2 to $41 \mu \mathrm{g} / \mathrm{g}$.

B2.2.3.3 Inductively Coupled Plasma. Samples were prepared by acid digestion, water digestion, or KOH fusion digestion. The major waste constituents identified by ICP spectroscopy were $\mathrm{Al}, \mathrm{Bi}, \mathrm{Ca}, \mathrm{Fe}, \mathrm{Mg}, \mathrm{Mn}, \mathrm{P}, \mathrm{Si}, \mathrm{Na}$, and $\mathrm{S}$; all were present in concentrations exceeding $1,000 \mu \mathrm{g} / \mathrm{g}$. Phosphorus and sulfur were analyzed as a cross check for the phosphate and sulfate results reported from IC analyses.

B2.2.3.4 Laser Fluorimetry. Uranium was analyzed by laser fluorimetry on fusion digestions of the solids and directly on the drainable liquids. Solids results ranged from 8,390 to $10,200 \mu \mathrm{g} / \mathrm{g}$.

B2.2.3.5 Chromium (VI) by Spectrophotometry. Hexavalent chromium was analyzed a water leach on the solids. The results were below analytical detection limits.

B2.2.3.6 Distillation/Titration. Ammonia analysis of tank 241-T-105 samples was performed on drainable liquids, core homogenizations, and hot cell and field blanks (Giamberardini 1993). No ammonia was detected.

B2.2.3.7 pH. Analysis of the $\mathrm{pH}$ for tank 241-T-105 samples was performed for liquid and solid samples. The pH was measured on drainable liquids, core homogenizations, and hot cell and field blanks. The pH values of the solids and core 53 drainable liquids ranged from 11.27 to 12.07 . The $\mathrm{pH}$ values for core 52 , segment 2 drainable liquids were much lower $(8.26$ and 8.29). 
B2.2.3.8 Ion Chromatography. Anions were determined on a water digestion of the sample. Ion chromatography was used to determine fluoride, chloride, nitrate, nitrite, phosphate, and sulfate concentrations. The most abundant anion in tank 241-T-105 waste was nitrite. Nitrate exhibited the second highest concentration among anions. Lesser amounts of sulfate, phosphate, chloride, and fluoride were also present.

B2.2.3.9 Potentiometric Titration. The hydroxide concentration was measured by potentiometric titration. Hydroxide values were below detection limits in the solids and averaged $367 \mu \mathrm{g} / \mathrm{mL}$ in drainable liquids.

B2.2.10 Distillation/Spectrometry. Cyanide analysis of the tank $241-\mathrm{T}-105$ samples was performed by distillation/spectrometry. The analysis was performed on segment 1 of cores 53 and 54 by direct analysis. Results ranged from 5.84 to $25.1 \mu \mathrm{g} / \mathrm{g}$.

B2.2.11 Nitrite by Spectrophotometry. Nitrite analysis by spectrophotometry was performed on the drainable liquids and on water digestions of the solids. Solids water digest values for nitrite were low. The average concentration in drainable liquids was $17,500 \mu \mathrm{g} / \mathrm{mL}$.

B2 2.3.12 Total Organic Carbon. Total organic carbon analysis was performed by furnace oxidation and persulfate oxidation on the drainable liquid, the two core segments that had solids, and the field and hot cell blanks. Little TOC was observed in drainable liquids. The maximum concentration of TOC in the solids was $5,380 \mu \mathrm{g} / \mathrm{g}$.

B2 2.3.13 Total Inorganic Carbon. Total inorganic carbon analysis was performed on the same samples as the TOC analyses. The TIC values ranged from 3,150 to $7,800 \mu \mathrm{g} / \mathrm{g}$ in the solids and 2,960 to $3,020 \mu \mathrm{g} / \mathrm{mL}$ in drainable liquids.

B2.2.3.14 Mass Spectroscopy. Isotopic uranium and plutonium were determined on fused samples. The primary isotopes were ${ }^{239} \mathrm{Pu}$ and ${ }^{238} \mathrm{U}$.

B2.2.3.15 Total Alpha and Alpha Emitters. The total alpha concentration was measured on the solids and liquids using alpha proportional counting. Total $\mathrm{Pu},{ }^{241} \mathrm{Am},{ }^{238} \mathrm{Pu}$, and ${ }^{2391240} \mathrm{Pu}$ were measured by alpha spectroscopy.

B2.2.3.16 Total Beta Activity. The total beta concentration was measured using beta proportional counting. Measurements were performed directly on the liquids and solids after water and fusion digestions. Strontium-90 also was measured by beta proportional counting. The analyses were performed on the drainable liquid and the solids after a fusion digestion.

B2.2.3.17 Gamma Energy Analysis. The gamma energy analyses were performed on the solids after fusion and water digestions. The primary analyte observed in all samples was ${ }^{137} \mathrm{Cs}$. All other GEA analytes were near or below detection limits. 
B2.2.3.18 Liquid Scintillation Counting. Carbon- 14 and ${ }^{3} \mathrm{H}$ analyses were performed by liquid scintillation counting on the water digested solids. The ${ }^{97} \mathrm{Tc}$ analyses were performed on drainable liquids and fusion digested solids.

B2.2.3.19 Percent Solids, Density, and Specific Gravity. Analysis for weight percent solids was carried out at the 222-S and the 325 Laboratories using gravimetric methods. In addition to weight percent total solids, weight percent analyses were performed on centrifuged solids from core 57 , segment 1 , exhibiting a result of 98 weight percent. A weight percent solids determination also was performed on the residual solids from a water digestion of the solids from segment 1 of core 54 .

Density measurements were determined directly. The density of segment 1 of core 57 was $1.54 \mathrm{~g} / \mathrm{mL}$; that of core 57 , segment 2 , was $1.74 \mathrm{~g} / \mathrm{mL}$. Density also was measured on diluted samples (1:3 and 1:1 dilutions) of segment 1 of core 57. The 1:1 dilution gave a density of $1.12 \mathrm{~g} / \mathrm{mL}$, and the $1: 3$ dilution gave a density of $1.03 \mathrm{~g} / \mathrm{mL}$. Densities were calculated on all segments by dividing the segment mass by the segment volume. In addition to the densities of the segments, density measurements were made on core 57, segment 1 centrifuged supernatant $(1.0 \mathrm{~g} / \mathrm{mL})$ and centrifuged solids $(1.56 \mathrm{~g} / \mathrm{mL})$.

Specific gravity was measured on segment 2 of cores 53 and 54 . The results for the drainable liquid samples were 1.05 on core 53 and 0.985 on core 54 .

Volume percent analyses were performed on settled solids from segments 1 and 2 of core 57 . The volume percent results for both segments were 100 volume percent solids, showing that no drainable liquid existed in the samples. A 1:1 and a 1:3 dilution of samples from both segments of core 57 was also carried out. Centrifuged solids exhibited volume percent results of 96 volume percent and 98 volume percent for segments 1 and 2, respectively.

B2 2.3.20 Total Dissolved Solids. The analysis for total dissolved solids is the same as that for the weight percent solids except that it is performed on a liquid sample. This analysis was performed on water digested solids from cores 53 and 54 . The average result for core 54, segment 1 , was 0.105 percent; for core 53 , segment $1,0.28$ percent.

B2.2.3.21 Particle Size. Particle size distribution analysis was performed on the as-received samples from segments 1 and 2 of core 57 . The mean diameter based on probability number density for both segments was $1.0 \mu \mathrm{m}$. The mean diameter based on probability volume density was $10 \mu \mathrm{m}$ for segment 1 and $17 \mu \mathrm{m}$ for segment 2 . Particle size was also measured on samples from segment 1 both of cores 53 and 54. For segment 1 of core 53 the mean diameter based on probability number density was $1.5 \mu \mathrm{m}$ and the mean diameter based on probability volume density was $1.5 \mu \mathrm{m}$. For segment 1 of core 54 , the probability number density was $1.5 \mu \mathrm{m}$, and the mean diameter based on the probability volume density was $20 \mu \mathrm{m}$. Plots of the particle size distribution based on the probability number density and the probability volume density are in the data package (Giamberardini 1993). 
B2.2.3.22 Rheology. Viscosity versus shear rate studies were performed on samples obtained from segments 1 and 2 of core 57. Segment 1 exhibited pseudoplastic behavior, that is, the viscosity of the waste decreased with increasing shear rate. The viscosity of a 1:1 dilution of segment 1 at ambient temperature decreased from 200 centipoise to 20 centipoise as shear rate increased from $50 \mathrm{~s}^{-1}$ to $450 \mathrm{~s}^{-1}$. These data were fit to a yield power law equation

(Giamberardini 1993). The 1:1 dilution of segment 2, however, displayed Newtonian behavior because the viscosity was relatively independent of shear rate; a slight decrease from 5 centipoise to 1 centipoise was observed as shear rate increased from $50 \mathrm{~s}^{-1}$ to $450 \mathrm{~s}^{-1}$. Plots of shear stress and viscosity as a function of shear rate for the dilutions are in the data package (Giamberardini 1993).

B2.2.3.23 Differential Scanning Calorimetry. In a DSC analysis, heat absorbed or emitted by a substance is measured while the temperature of the sample is heated at a constant rate. Nitrogen is passed over the sample material to remove any gases being released. The onset temperature for an endothermic or exothermic event is determined graphically.

The DSC analyses yielded exotherms in samples originating from cores 53 and 57; however, exotherms were not observed in the core 54 samples. The DSC plots of the samples also generally yielded two endothermic transition regions. Only exothermic results are shown in the tables.

For segment 1 of core 53, small exotherms were found in transitions two and three. These transitions occurred at peak temperatures of approximately $333{ }^{\circ} \mathrm{C}\left(320^{\circ} \mathrm{C}\right.$ to $350{ }^{\circ} \mathrm{C}$ range) and $447^{\circ} \mathrm{C}\left(420^{\circ} \mathrm{C}\right.$ to $460^{\circ} \mathrm{C}$ range). These exotherms released, on a wet weight basis, $13.0 \mathrm{~J} / \mathrm{g}$ and $17.3 \mathrm{~J} / \mathrm{g}$, respectively. Segment 1 of core $57 \mathrm{had}$ a broad exotherm in the 150 to $320^{\circ} \mathrm{C}$ range with an average $175 \mathrm{~J} / \mathrm{g}$ energy release (wet weight basis).

B2.2.3.24 Thermogravimetric Analyses. Thermogravimetric analysis measures the mass of a sample while the temperature of the sample is increased at a constant rate. Nitrogen is passed over the sample during heating to remove any released gases. Any decrease in the weight of a sample during TGA represents a loss of gaseous matter from the sample through evaporation or a reaction that forms gas phase products. The moisture content is estimated by assuming that all TGA sample weight loss up to a certain temperature (typically $150^{\circ} \mathrm{C}$ to $200^{\circ} \mathrm{C}$ ) is caused by water evaporation. The temperature limit for moisture loss is chosen by the operator at an inflection point on the TGA plot. Likewise, other volatile matter fractions can often be differentiated by inflection points.

Segment 1 of core 53 had a loss of 51.97 percent between room temperature and $135^{\circ} \mathrm{C}$, and segment 2 of core 53 had an average loss of 91.39 percent between room temperature and about $100^{\circ} \mathrm{C}$. Segment 2 of core 54 had a loss of 35.52 percent between room temperature and $130^{\circ} \mathrm{C}$. Segments 1 and 2 of core 57 had average losses of 47.6 percent (between $30^{\circ} \mathrm{C}$ and $153^{\circ} \mathrm{C}$ ) and 20 percent (between $31^{\circ} \mathrm{C}$ and $120^{\circ} \mathrm{C}$ ), respectively. 


\section{B2.3 VAPOR PHASE MEASUREMENT}

Combustible gas headspace tests were conducted on May 9, 1996 and on June 27, 1997. These measurements support the safety screening DQO (Dukelow et al. 1995). The flammability of the headspace vapors was 0 percent of the LFL in both tests. The ammonia concentration was $150 \mathrm{ppmv}$ in 1996 and $100 \mathrm{ppmv}$ in 1997. The TOC concentration was $5 \mathrm{ppmv}$ in 1996 and 0 ppmv in 1997. Oxygen $\left(\mathrm{O}_{2}\right)$ concentrations were 20.8 and 20.9. No vapor samples have.been taken or are scheduled for tank 241-T-105.

\section{B2.4 HISTORICAL SAMPLE RESULTS}

Analytical data for tank 241-T-105 is available for a 1974 liquid sample. Sample T-4927 was dark amber in color, and had traces of solids (Wheeler 1974). No other information regarding the sampling event was available. The earliest sample information available was for a sample analyzed March 1965 (Godfrey 1965). No information was available regarding sample handling, sample depth, or the riser. The 1974 and 1965 samples were taken before the tank was interim stabilized and are not representative of current tank contents. 
HNF-SD-WM-ER-369 Rev. 2

\section{ANALYTICAL RESULTS}

Table B2-12. Tank 241-T-105 Analytical Results: Aluminum (ICP):

\begin{tabular}{|c|c|c|c|c|c|}
\hline Tinilier & Sample & 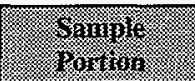 & incint & mivirate & 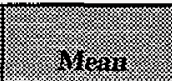 \\
\hline \multicolumn{2}{|c|}{ 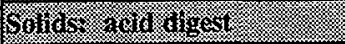 } & 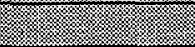 & 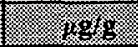 & $1.1864:$ & 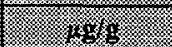 \\
\hline S97T001687 & \multirow{3}{*}{$\begin{array}{l}205: 2 \\
\text { Clear crystals } \\
\text { Dark crystals }\end{array}$} & Lower half & 14,200 & 26,100 & $20,200^{\mathrm{eC:d,e,h}}$ \\
\hline S97T002007 & & Lower half & 59,000 & 837 & $29,900^{\mathrm{eC}: c, e, \mathrm{~h}}$ \\
\hline S97T002016 & & Lower half & 172,000 & 193,000 & $1.83 \mathrm{E}+05^{\mathrm{QC:d}}$ \\
\hline S97T001699 & 207:1 & Lower half & 30,100 & 40,500 & $35,300^{\mathrm{QC}: \mathrm{c}}$ \\
\hline S97T001712 & \multirow[t]{2}{*}{$207: 2$} & Upper half & 21,400 & 23,600 & 22,500 \\
\hline S97T001705 & & Lower half & 23,000 & 21,000 & $22,000^{\alpha: c}$ \\
\hline 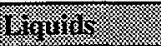 & & 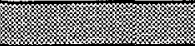 & 4.869111 & 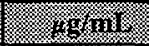 & $2.8 \mathrm{grvol}$ \\
\hline S97T001676 & $205: 1$ & Drainable liquid & 341 & 360 & 351 \\
\hline S97T001679 & $205: 2$ & Drainable liquid & 189 & 194 & 192 \\
\hline S97T001692 & $207: 1$ & Drainable liquid & 485 & 480 & 483 \\
\hline
\end{tabular}

Table B2-13. Tank 241-T-105 Analytical Results: Antimony (ICP).

\begin{tabular}{|c|c|c|c|c|c|}
\hline Jamives & 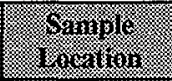 & 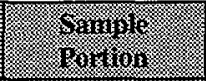 & ressin: & 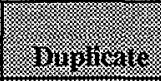 & 18. \\
\hline \multicolumn{3}{|c|}{ Surub arid Giger, } & 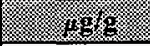 & 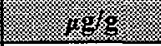 & 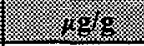 \\
\hline S97T001687 & \multirow{3}{*}{\begin{tabular}{|l}
$205: 2$ \\
Clear crystals \\
Dark crystals \\
\end{tabular}} & Lower half & $<86.8$ & $<87.5$ & $<87.2$ \\
\hline \$97T002007 & & Lower half & $<23.5$ & $<37.8$ & $<30.6$ \\
\hline S97T002016 & & Lower half & $<24.8$ & $<17.3$ & $<21.1$ \\
\hline S97T001699 & $207: 1$ & Lower half & $<86.3$ & $<86.7$ & $<86.5$ \\
\hline S97T001712 & \multirow[t]{2}{*}{$207: 2$} & Upper half & $<85.5$ & $<85$ & $<85.3$ \\
\hline S97T001705 & & Lower half & $<85.6$ & $<86$ & $<85.8$ \\
\hline Larinas & 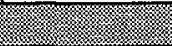 & 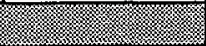 & 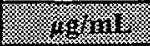 & 1.061012 & . \\
\hline S97T001676 & $205: 1$ & Drainable liquid & $<24.1$ & $<24.1$ & $<24.1$ \\
\hline S97T001679 & $205: 2$ & Drainable liquid & $<24.1$ & $<24.1$ & $<24.1$ \\
\hline S97T001692 & $207: 1$ & Drainable liquid & $<24.1$ & $<24.1$ & $<24.1$ \\
\hline
\end{tabular}


Table B2-14. Tank 241-T-105 Analytical Results: Arsenic (ICP).

\begin{tabular}{|c|c|c|c|c|c|}
\hline vimile & $\begin{array}{l}\text { Samples: } \\
\text { Srivation }\end{array}$ & 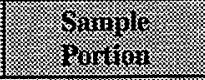 & mesiun & 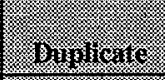 & igsin: \\
\hline \multicolumn{3}{|c|}{ 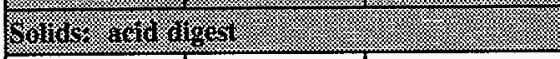 } & 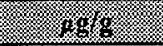 & 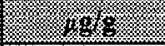 & 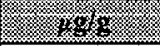 \\
\hline S97T001687 & \multirow{3}{*}{$\begin{array}{l}205: 2 \\
\text { Clear crystals } \\
\text { Dark crystals }\end{array}$} & Lower half & $<145$ & $<146$ & $<146$ \\
\hline S97T002007 & & Lower half & $<39.2$ & $<63$ & $<51.1$ \\
\hline S97T002016 & & Lower half & $<41.4$ & $<28.9$ & $<35.1$ \\
\hline S97T001699 & $207: 1$ & Lower half & $<144$ & $<145$ & $<145$ \\
\hline S97T001712 & \multirow[t]{2}{*}{$207: 2$} & Upper half & $<142$ & $<142$ & $<142$ \\
\hline S97T001705 & & Lower half & $<143$ & $<143$ & $<143$ \\
\hline 1igrias & & & $6.1894 n 13$ & 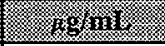 & 88610 \\
\hline S97T001676 & 205:1 & Drainable liquid & $<40.1$ & $<40.1$ & $<40.1$ \\
\hline S97T001679 & 205:2 & Drainable liquid & $<40.1$ & $<40.1$ & $<40.1$ \\
\hline S97T001692 & 207:1 & Drainable liquid & $<40.1$ & $<40.1$ & $<40.1$ \\
\hline
\end{tabular}

Table B2-15. Tank 241-T-105 Analytical Results: Barium (ICP).

\begin{tabular}{|c|c|c|c|c|c|}
\hline Suringin & (2) & 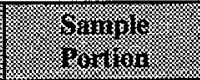 & 68, 1118 & 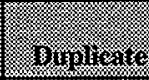 & 18 \\
\hline \multicolumn{3}{|c|}{ 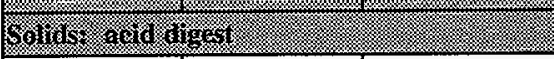 } & 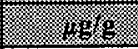 & $1.98 \%$ & 3.97 \\
\hline S97T001687 & \multirow{3}{*}{$\begin{array}{l}205: 2 \\
\text { Clear crystals } \\
\text { Dark crystals }\end{array}$} & Lower half & 88.5 & 89.5 & 89 \\
\hline S97T002007 & & Lower half & $<19.6$ & $<31.5$ & $<25.6$ \\
\hline S97T002016 & & Lower half & $<20.7$ & $<14.4$ & $<17.6$ \\
\hline S97T001699 & $207: 1$ & Lower half & $<71.9$ & $<72.3$ & $<72.1$ \\
\hline S97T001712 & \multirow[t]{2}{*}{$207: 2$} & Upper half & $<71.2$ & $<70.8$ & $<71$ \\
\hline S97T001705 & & Lower half & $<71.3$ & $<71.7$ & $<71.5$ \\
\hline \multicolumn{3}{|l|}{ 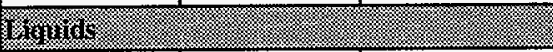 } & 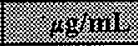 & 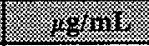 & 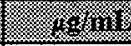 \\
\hline S97T001676 & 205:1 & Drainable liquid & $<20.1$ & $<20.1$ & $<20.1$ \\
\hline S97T001679 & $205: 2$ & Drainable liquid & $<20.1$ & $<20.1$ & $<20.1$ \\
\hline S97T001692 & $207: 1$ & Drainable liquid & $<20.1$ & $<20.1$ & $<20.1$ \\
\hline
\end{tabular}


Table B2-16. Tank 241-T-105 Analytical Results: Beryllium (ICP).

\begin{tabular}{|c|c|c|c|c|c|}
\hline Vinivie & S Sampilc & Timmile & resing. & Duningerte & 2.18 \\
\hline \multicolumn{3}{|c|}{ Solifer arid higet } & 8.968 & 18985 & (x) \\
\hline S97T001687 & \multirow{3}{*}{$\begin{array}{l}205: 2 \\
\text { Clear crystals } \\
\text { Dark crystals }\end{array}$} & Lower half & $<7.23$ & $<7.29$ & $<7.26$ \\
\hline S97T002007 & & Lower half & $<1.96$ & $<3.15$ & $<2.55$ \\
\hline S97T002016 & & Lower half & $<2.07$ & $<1.44$ & $<1.75$ \\
\hline S97T001699 & $207: 1$ & Lower half & $<7.19$ & $<7.23$ & $<7.21$ \\
\hline S97T001712 & \multirow[t]{2}{*}{$207: 2$} & Upper half & $<7.12$ & $<7.08$ & $<7.1$ \\
\hline S97T001705 & & Lower half & $<7.13$ & $<7.17$ & $<7.15$ \\
\hline \multicolumn{2}{|l|}{ Firgurats } & & 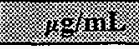 & 16: & 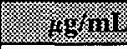 \\
\hline S97T001676 & $205: 1$ & Drainable liquid & $<2$ & $<2$ & $<2$ \\
\hline S97T001679 & $205: 2$ & Drainable liquid & $<2$ & $<2$ & $<2$ \\
\hline S97T001692 & $207: 1$ & Drainable liquid & $<2$ & $<2$ & $<2$ \\
\hline
\end{tabular}

Table B2-17. Tank 241-T-105 Analytical Results: Bismuth (ICP).

\begin{tabular}{|c|c|c|c|c|c|}
\hline 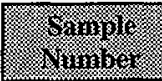 & (5) & 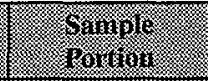 & resisis: & sompinges & 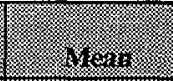 \\
\hline \multicolumn{3}{|c|}{ 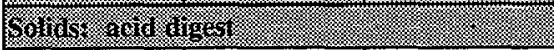 } & 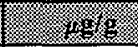 & 4.98 & 4.8 .1 .68 \\
\hline S97T001687 & \multirow{3}{*}{$\begin{array}{l}205: 2 \\
\text { Clear crystals } \\
\text { Dark crystals }\end{array}$} & Lower half & 1,600 & $1 ; 670$ & 1,640 \\
\hline S97T002007 & & Lower half & 107 & 65.6 & $86.3^{\left(C_{i e}\right.}$ \\
\hline S97T002016 & & Lower half & 166 & 156 & 161 \\
\hline S97T001699 & $207: 1$ & Lower half & 2,090 & 2,280 & 2,190 \\
\hline S97T001712 & \multirow[t]{2}{*}{$207: 2$} & Upper half & 27,100 & 27,900 & 27,500 \\
\hline S97T001705 & & Lower half & 40,300 & 38,100 & $39,200^{\mathrm{QC:c}}$ \\
\hline \multicolumn{3}{|l|}{ 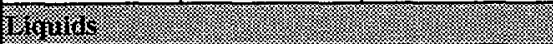 } & $1.4 \mathrm{~g} . \mathrm{mi}$ & 3.8.8.10 & 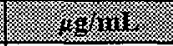 \\
\hline S97T001676 & $205: 1$ & Drainable liquid & $<40.1$ & $<40.1$ & $<40.1$ \\
\hline S97T001679 & $205: 2$ & Drainable liquid & $<40.1$ & $<40.1$ & $<40.1$ \\
\hline S97T001692 & $207: 1$ & Drainable liquid & $<40.1$ & $<40.1$ & $<40.1$ \\
\hline
\end{tabular}


Table B2-18. Tank 241-T-105 Analytical Results: Boron (ICP).

\begin{tabular}{|c|c|c|c|c|c|}
\hline VIringles: & 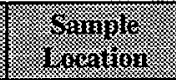 & 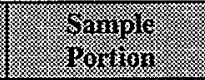 & Resin: & Dinitivate & in enis: \\
\hline \multicolumn{2}{|c|}{ binits a vid ngeri: } & স্য। & 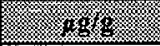 & 3.1 .65 & 86 \\
\hline S97,T001687 & \multirow{3}{*}{$\begin{array}{l}205: 2 \\
\text { Clear crystals } \\
\text { Dark crystals }\end{array}$} & Lower half & 72.6 & $<72.9$ & $<72.8$ \\
\hline S97T002007 & & Lower half & 160 & 660 & $410^{\mathrm{Qcie}}$ \\
\hline S97T002016 & & Lower half & 150 & 100 & $125^{\mathrm{QC}: e}$ \\
\hline S97T001699 & $207: 1$ & Lower half & 104 & 75.1 & $89.5^{\text {QC:e }}$ \\
\hline S97T001712 & \multirow[t]{2}{*}{$207: 2$} & Upper half & $<71.2$ & $<70.8$ & $<71$ \\
\hline \$97T001705 & & Lower half & $<71.3$ & $<71.7$ & $<71.5$ \\
\hline \multicolumn{3}{|l|}{ 19onds } & /gint & (1) & 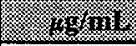 \\
\hline S97T001676 & 205:1 & Drainable liquid & $<20.1$ & $<20.1$ & $<20.1$ \\
\hline S97T001679 & $205: 2$ & Drainable liquid & $<20.1$ & $<20.1$ & $<20.1$ \\
\hline S9TT001692 & 207:1 & Drainable liquid & $<20.1$ & $<20.1$ & $<20.1$ \\
\hline
\end{tabular}

Table B2-19. Tank 241-T-105 Analytical Results: Cadmium (ICP).

\begin{tabular}{|c|c|c|c|c|c|}
\hline 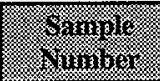 & Sumpics & 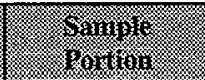 & Resul: & 3 3 & Hicin: \\
\hline \multicolumn{3}{|c|}{ 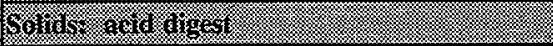 } & (1) & 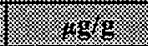 & 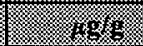 \\
\hline S97T001687 & \multirow{3}{*}{$\begin{array}{l}205: 2 \\
\text { Clear crystals } \\
\text { Dark crystals }\end{array}$} & Lower half & 7.89 & 10.7 & $9.29^{Q \mathrm{C}: 0}$ \\
\hline$\$ 97 T 002007$ & & Lower half & $<1.96$ & $<3.15$ & $<2.55$ \\
\hline S97T002016 & & Lower half & $<2.07$ & $<1.44$ & $<1.75$ \\
\hline S97T001699 & $207: 1$ & Lower half & $<7.19$ & $<7.23$ & $<7.21$ \\
\hline S97T001712 & \multirow[t]{2}{*}{$207: 2$} & Upper half & 7.17 & $<7.08$ & $<7.13$ \\
\hline S97T001705 & & Lower half & 8 & $<7.17$ & $<7.59$ \\
\hline \multicolumn{2}{|l|}{ mings: } & $\frac{1}{478}$ & $1.88,1.10$ & . & $18.6 \times 18$ \\
\hline S97T001676 & 205:1 & Drainable liquid & $<2$ & 2.61 & $<2.3$ \\
\hline S97T001679 & $205: 2$ & Drainable liquid & $<2$ & $<2$ & $<2$ \\
\hline S97T001692 & $207: 1$ & Drainable liquid & 2.23 & $<2$ & $<2.12$ \\
\hline
\end{tabular}


Table B2-20. Tank 241-T-105 Analytical Results: Calcium (ICP).

\begin{tabular}{|c|c|c|c|c|c|}
\hline Oninitic & Surngle & $\begin{array}{l}\text { Sample } \\
\text { Jom }\end{array}$ & Inil & rom thente & 118u. \\
\hline \multicolumn{2}{|c|}{ 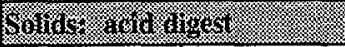 } & (1) & $=3198$ & 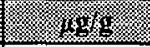 & 8.88 \\
\hline S97T001687 & \multirow{3}{*}{$\begin{array}{l}205: 2 \\
\text { Clear crystals } \\
\text { Dark crystals }\end{array}$} & Lower half & 496 & 466 & 481 \\
\hline S97T002007 & & Lower half & 112 & 127 & 120 \\
\hline S97T002016 & & Lower half & 218 & 168 & $193^{\text {QC:e }}$ \\
\hline S97T001699 & $207: 1$ & Lower half & 1,070 & 1,140 & 1,110 \\
\hline S97T001712 & \multirow[t]{2}{*}{$207: 2$} & Upper half & 555 & 486 & 521 \\
\hline S97T001705 & & Lower half & 625 & 519 & 572 \\
\hline Signidis & \multicolumn{2}{|c|}{10} & (2. & (8) & 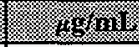 \\
\hline S97T001676 & $205: 1$ & Drainable liquid & 72.2 & 73.3 & 72.8 \\
\hline S97T001679 & $205: 2$ & Drainable liquid & 64.6 & 63.5 & 64 \\
\hline S97T001692 & $207: 1$ & Drainable liquid & 80.3 & 79.1 & 79.7 \\
\hline
\end{tabular}

Table B2-21. Tank 241-T-105 Analytical Results: Cerium (ICP).

\begin{tabular}{|c|c|c|c|c|c|}
\hline 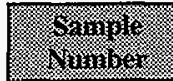 & ( & 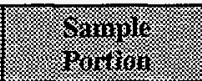 & 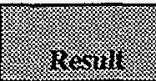 & 3inoticin & $\sqrt{13}$ \\
\hline \multicolumn{2}{|c|}{ Solfer arid algevi: } & $\sqrt{4}$ & 莓 & 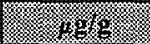 & 79 \\
\hline S97T001687 & \multirow{3}{*}{$\begin{array}{l}205: 2 \\
\text { Clear crystals } \\
\text { Dark crystals }\end{array}$} & Lower half & $<145$ & $<146$ & $<146$ \\
\hline S97T002007 & & Lower half & $<39.2$ & $<63$ & $<51.1$ \\
\hline S97T002016 & & Lower half & $<41.4$ & $<28.9$ & $<35.1$ \\
\hline S97T001699 & 207:1 & Lower half & $<144$ & $<145$ & $<145$ \\
\hline S97T001712 & \multirow[t]{2}{*}{$207: 2$} & Upper half & $<142$ & $<142$ & $<142$ \\
\hline S97T001705 & & Lower half & $<143$ & $<143$ & $<143$ \\
\hline Hirinins: & & 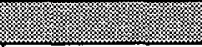 & 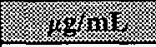 & og. & 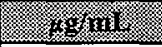 \\
\hline S9TT001676 & 205:1 & Drainable liquid & $<40.1$ & $<40.1$ & $<40.1$ \\
\hline S97T001679 & $205: 2$ & Drainable liquid & $<40.1$ & $<40.1$ & $<40.1$ \\
\hline S97T001692 & 207:1 & Drainable liquid & $<40.1$ & $<40.1$ & $<40.1$ \\
\hline
\end{tabular}


Table B2-22. Tank 241-T-105 Analytical Results: Chromium (ICP).

\begin{tabular}{|c|c|c|c|c|c|}
\hline 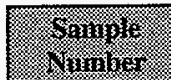 & 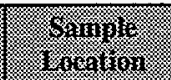 & Smonts: & Iresintis & 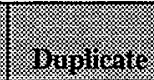 & 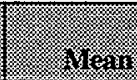 \\
\hline \multicolumn{3}{|c|}{ 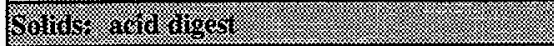 } & 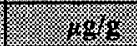 & $4,8 \mathrm{~g} 8$ & 10858 \\
\hline S97T001687 & \multirow{3}{*}{$\begin{array}{l}205: 2 \\
\text { Clear crystals } \\
\text { Dark crystals }\end{array}$} & Lower half & 657 & 669 & 663 \\
\hline S97T002007 & & Lower half & 4.89 & 8.07 & $6.48^{\mathrm{QC:c}}$ \\
\hline S97T002016 & & Lower half & 5.24 & 5.53 & 5.38 \\
\hline S97T001699 & $207: 1$ & Lower half & 636 & 697 & 667 \\
\hline S97T001712 & \multirow[t]{2}{*}{$207: 2$} & Upper half & 2,200 & 2,190 & 2,200 \\
\hline S97T001705 & & Lower half & 1,720 & 1,830 & 1,780 \\
\hline \multicolumn{3}{|l|}{ Mrginds } & 189.171. & 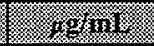 & 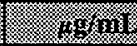 \\
\hline S9TT001676 & $205: 1$ & Drainable liquid & 251 & 265 & 258 \\
\hline S97T001679 & $205: 2$ & Drainable liquid & 244 & 248 & 246 \\
\hline S97T001692 & $207: 1$ & Drainable liquid & 154 & 152 & 153 \\
\hline
\end{tabular}

Table B2-23. Tank 241-T-105 Analytical Results: Cobalt (ICP).

\begin{tabular}{|c|c|c|c|c|c|}
\hline Sininets & 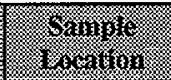 & binging & 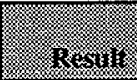 & 64,11140 & 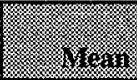 \\
\hline Solings war & 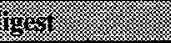 & "IV & 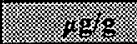 & 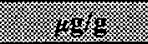 & $3 x$ \\
\hline S97T001687. & \multirow{3}{*}{$\begin{array}{l}205: 2 \\
\text { Clear crystals } \\
\text { Dark crystals }\end{array}$} & Lower half & $<28.9$ & $<29.2$ & $<29$ \\
\hline S97T002007 & & Lower half & $<7.84$ & $<12.6$ & $<10.2$ \\
\hline S97T002016 & & Lower half & $<8.27$ & $<5.77$ & $<7.02$ \\
\hline S97T001699 & $207: 1$ & Lower half & $<28.8$ & $<28.9$ & $<28.9$ \\
\hline S97T001712 & \multirow[t]{2}{*}{$207: 2$} & Upper half & $<28.5$ & $<28.3$ & $<28.4$ \\
\hline S97T001705 & & Lower half & $<28.5$ & $<28.7$ & $<28.6$ \\
\hline 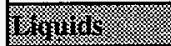 & & & 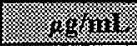 & $4.2 \mathrm{~min}$ & . 1.98 .17 \\
\hline S97T001676 & 205:1 & Drainable liquid & $<8.02$ & $<8.02$ & $<8.02$ \\
\hline S97T001679 & $205: 2$ & Drainable liquid & $<8.02$ & $<8.02$ & $<8.02$ \\
\hline S97T001692 & $207: 1$ & Drainable liquid & $<8.02$ & $<8.02$ & $<8.02$ \\
\hline
\end{tabular}


Table B2-24. Tank 241-T-105 Analytical Results: Copper (ICP).

\begin{tabular}{|c|c|c|c|c|c|}
\hline Vaningle: & $\begin{array}{l}\text { Sammil } \\
\text { Wrication }\end{array}$ & $\begin{array}{l}\text { Yhimple } \\
\text { poriton }\end{array}$ & ingsint & 3Mriliente & 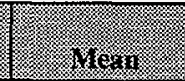 \\
\hline 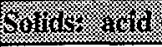 & 19est - & ( & 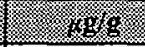 & l & 1.96 \\
\hline S97T001687 & \multirow{3}{*}{$\begin{array}{l}205: 2 \\
\text { Clear crystals } \\
\text { Dark crystals }\end{array}$} & Lower half & $<14.5$ & $<14.6$ & $<14.6$ \\
\hline S97T002007 & & Lower half & 26.4 & $<6.3$ & $<16.3$ \\
\hline S97T002016 & & Lower half & 38.7 & 29.7 & $34.2^{\mathrm{QC:O}}$ \\
\hline S97T001699 & $207: 1$ & Lower half & 23.4 & 23.7 & 23.5 \\
\hline S97T001712 & \multirow[t]{2}{*}{$207: 2$} & Upper half & 69.4 & 945 & $507^{Q C: 0}$ \\
\hline S97T001705 & & Lower half & 24.7 & 492 & $258^{\mathrm{QC}: \mathrm{e}}$ \\
\hline Hithids. & & (1) & I. & 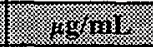 & 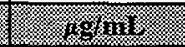 \\
\hline S97T001676 & $205: 1$ & Drainable liquid & $<4.01$ & $<4.01$ & $<4.01$ \\
\hline S97T001679 & 205:2 & Drainable liquid & $<4.01$ & $<4.01$ & $<4.01$ \\
\hline S97T001692 & $207: 1$ & Drainable liquid & 7.34 & 7.28 & 7.31 \\
\hline
\end{tabular}

Table B2-25. Tank 241-T-105 Analytical Results: Iron (ICP).

\begin{tabular}{|c|c|c|c|c|c|}
\hline 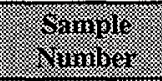 & 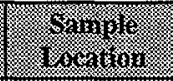 & 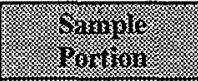 & Presing: & 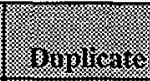 & $(\sqrt{3})=$ \\
\hline \multicolumn{2}{|c|}{ 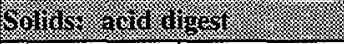 } & 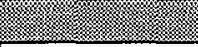 & $\sqrt{15}$ & 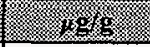 & 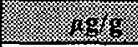 \\
\hline S97T001687 & \multirow{3}{*}{$\begin{array}{l}205: 2 \\
\text { Clear crystals } \\
\text { Dark crystals }\end{array}$} & Lower half & 11,700 & 12,100 & 11,900 \\
\hline S97T002007 & & Lower half & 201 & 72.2 & $137^{\mathrm{QC:c,c}, \mathrm{c}}$ \\
\hline S97T002016 & & Lower half & 534 & 485 & $510^{\alpha \mathrm{CC} C}$ \\
\hline S97T001699 & $207: 1$ & Lower half & 9,860 & 11,200 & 10,500 \\
\hline \$97T001712 & \multirow[t]{2}{*}{$207: 2$} & Upper half & 31,800 & 33,900 & 32,900 \\
\hline S97T001705 & & Lower half & 35,900 & 33,800 & $34,900^{\mathrm{QC}: \mathrm{c}}$ \\
\hline 1014 ing & & & (3) & (28.8. & 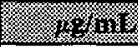 \\
\hline S97T001676 & $205: 1$ & Drainable liquid & $<20.1$ & $<20.1$ & $<20.1$ \\
\hline S97T001679 & 205:2 & Drainable liquid & $<20.1$ & $<20.1$ & $<20.1$ \\
\hline S97T001692 & $207: 1$ & Drainable liquid & $<20.1$ & $<20.1$ & $<20.1$ \\
\hline
\end{tabular}


Table B2-26. Tank 241-T-105 Analytical Results: Lanthanum (ICP).

\begin{tabular}{|c|c|c|c|c|c|}
\hline (7) & (4) & 46 & 372541 & 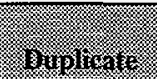 & 16211 \\
\hline 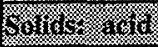 & $\mathrm{l}_{\mathrm{g}}$ & & 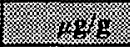 & (1) & 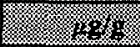 \\
\hline S97T001687 & \multirow{3}{*}{$\begin{array}{l}205: 2 \\
\text { Clear crystals } \\
\text { Dark crystals }\end{array}$} & Lower half & $<72.3$ & $<72.9$ & $<72.6$ \\
\hline S97T002007 & & Lower half & $<19.6$ & $<31.5$ & $<25.6$ \\
\hline S97T002016 & & Lower half & $<20.7$ & $<14.4$ & $<17.6$ \\
\hline S97T001699 & $207: 1$ & Lower half & $<71.9$ & $<72.3$ & $<72.1$ \\
\hline \$97T001712 & \multirow[t]{2}{*}{$207: 2$} & Upper half & $<71.2$ & $<70.8$ & $<71$ \\
\hline S97T001705 & & Lower half & $<71.3$ & $<71.7$ & $<71.5$ \\
\hline W & 4 & (2) & 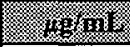 & (r) & (3) \\
\hline S97T001676 & 205:1 & Drainable liquid & $<20.1$ & $<20.1$ & $<20.1$ \\
\hline S97T001679 & $205: 2$ & Drainable liquid & $<20.1$ & $<20.1$ & $<20.1$ \\
\hline S97T001692 & $207: 1$ & Drainable liquid & $<20.1$ & $<20.1$ & $<20.1$ \\
\hline
\end{tabular}

Table B2-27. Tank 241-T-105 Analytical Results: Lead (ICP).

\begin{tabular}{|c|c|c|c|c|c|}
\hline Sim & oforinging & 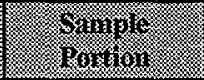 & 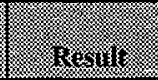 & 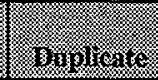 & 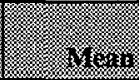 \\
\hline \multicolumn{3}{|c|}{ 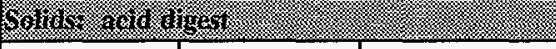 } & 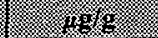 & r. & \multirow{2}{*}{472} \\
\hline \$97T001687 & \multirow{3}{*}{$\begin{array}{l}205: 2 \\
\text { Clear crystals } \\
\text { Dark crystals }\end{array}$} & Lower half & 473 & 470 & \\
\hline S97T002007 & & Lower half & $<39.2$ & $<63$ & $<51.1$ \\
\hline S97T002016 & & Lower half & $<41.4$ & $<28.9$ & $<35.1$ \\
\hline \$97T001699 & $207: 1$ & Lower half & 412 & 415 & 414 \\
\hline \$97T001712 & $207: 2$ & Upper half & 828 & 865 & 847 \\
\hline S97T001705 & . & Lower half & 1,010 & 835 & 923 \\
\hline Hixula & & & $f_{2}$ & (1) & 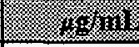 \\
\hline S97T001676 & 205:1 & Drainable liquid & $<40.1$ & $<40.1$ & $<40.1$ \\
\hline S97T001679 & 205:2 & Drainable liquid & $<40.1$ & $<40.1$ & $<40.1$ \\
\hline \$97T001692 & $207: 1$ & Drainable liquid & $<40.1$ & $<40.1$ & $<40.1$ \\
\hline
\end{tabular}


Table B2-28. Tank 241-T-105 Analytical Results: Lithium (ICP). ${ }^{1}$

\begin{tabular}{|c|c|c|c|c|c|}
\hline 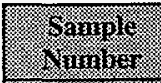 & 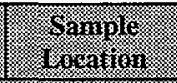 & sampies & Resillo & miningat & Stosin: \\
\hline \multicolumn{3}{|c|}{ 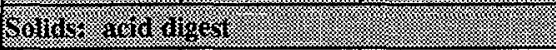 } & (6) & 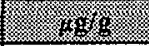 & (.) \\
\hline S97T001687 & \multirow{3}{*}{$\begin{array}{l}205: 2 \\
\text { Clear crystals } \\
\text { Dark crystals }\end{array}$} & Lower half & 111 & 110 & 111 \\
\hline S97T002007 & & Lower half & 4.1 & $<6.3$ & $<5.2$ \\
\hline S97T002016 & & Lower half & 5.21 & 6 & 5.61 \\
\hline S97T001699 & $207: 1$ & Lower half & $<14.4$ & $<14.5$ & $<14.4$ \\
\hline S97T001712 & \multirow[t]{2}{*}{$207: 2$} & Upper half & 42 & 44.2 & 43.1 \\
\hline S97T001705 & & Lower half & 123 & 106 & 115 \\
\hline \multicolumn{3}{|l|}{ molomis } & 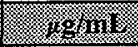 & $108 \times 101$ & 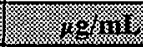 \\
\hline S97T001676 & 205:1 & Drainable liquid & $<4.01$ & $<4.01$ & $<4.01$ \\
\hline S97T001679 & 205:2 & Drainable liquid & 97.8 & 100 & 98.9 \\
\hline S97T001692 & $207: 1$ & Drainable liquid & $<4.01$ & $<4.01$ & $<4.01$ \\
\hline
\end{tabular}

Note:

${ }^{1}$ Lithium bromide was used as tracer fluid. Lithium is not a constituent in tank waste.

Table B2-29. Tank 241-T-105 Analytical Results: Magnesium (ICP).

\begin{tabular}{|c|c|c|c|c|c|}
\hline Siminger & ( & 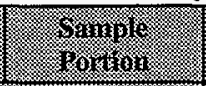 & grstis & 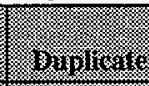 & 1. \\
\hline \multicolumn{2}{|c|}{ 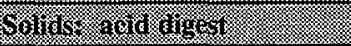 } & 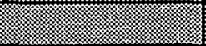 & $1.80 \mathrm{c} 6 \mathrm{~s}$ & 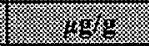 & 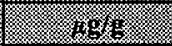 \\
\hline S97T001687 & \multirow{3}{*}{$\begin{array}{l}205: 2 \\
\text { Clear crystals } \\
\text { Dark crystals }\end{array}$} & Lower half & 1,130 & 1,140 & 1,140 \\
\hline S97T002007 & & Lower half & $<39.2$ & $<63$ & $<51.1$ \\
\hline S97T002016 & & Lower half & 54.5 & 43.4 & $49^{\mathrm{QC:e}}$ \\
\hline S97T001699 & $207: 1$ & Lower half & 802 & 857 & 830 \\
\hline S97T001712 & \multirow[t]{2}{*}{$207: 2$} & Upper half & 361 & 359 & 360 - \\
\hline S97T001705 & & Lower half & 286 & 274 & 280 \\
\hline Shuris: & (1) & 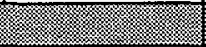 & (3.18. & . & 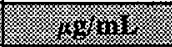 \\
\hline S97T001676 & 205:1 & Drainable liquid & $<40.1$ & $<40.1$ & $<40.1$ \\
\hline S97T001679 & $205: 2$ & Drainable liquid & $<40.1$ & $<40.1$ & $<40.1$ \\
\hline S97T001692 & $207: 1$ & Drainable liquid & $<40.1$ & $<40.1$ & $<40.1$ \\
\hline
\end{tabular}


Table B2-30. Tank 241-T-105 Analytical Results: Manganese (ICP).

\begin{tabular}{|c|c|c|c|c|c|}
\hline Vimoles: & 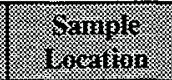 & 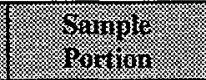 & irestit: & Buplinat & $\sqrt{15}$ \\
\hline \multicolumn{2}{|c|}{ 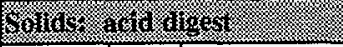 } & 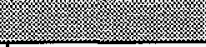 & 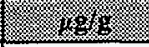 & 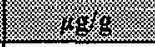 & 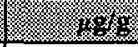 \\
\hline S97T001687 & \multirow{3}{*}{$\begin{array}{l}205: 2 \\
\text { Clear crystals } \\
\text { Dark crystals }\end{array}$} & Lower half & 12,500 & 12,700 & $12,600^{\mathrm{Oc}: \mathrm{c}}$ \\
\hline S97T002007 & & Lower half & 15.2 & 16 & 15.6 \\
\hline S97T002016 & & Lower half & 115 & 106 & 111 \\
\hline S97T001699 & $207: 1$ & Lower half & 9,160 & 10,200 & 9,680 \\
\hline S97T001712 & \multirow[t]{2}{*}{$207: 2$} & Upper half & 3,690 & 3,710 & 3,700 \\
\hline S97T001705 & & Lower half & 137 & 130 & 134 \\
\hline \multicolumn{2}{|l|}{ Lanids } & (2): & 18.464 mi: & 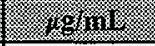 & 8.46 \\
\hline S97T001676 & 205:1 & Drainable liquid & $<4.01$ & $<4.01$ & $<4.01$ \\
\hline S97T001679 & 205:2 & Drainable liquid & $<4.01$ & $<4.01$ & $<4.01$ \\
\hline S97T001692 & $207: 1$ & Drainable liquid & $<4.01$ & $<4.01$ & $<4.01$ \\
\hline
\end{tabular}

Table B2-31. Tank 241-T-105 Analytical Results: Molybdenum (ICP).

\begin{tabular}{|c|c|c|c|c|c|}
\hline Shiniles: & f) & $\frac{3}{3}$ & fresulin & 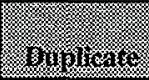 & Men \\
\hline \multicolumn{3}{|c|}{ 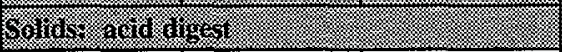 } & 3.135 & 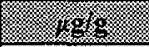 & 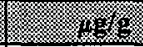 \\
\hline S97T001687 & \multirow{3}{*}{$\begin{array}{l}205: 2 \\
\text { Clear crystals } \\
\text { Dark crystals }\end{array}$} & Lower half & $<72.3$ & $<72.9$ & $<72.6$ \\
\hline S97T002007 & & Lower half & $<19.6$ & $<31.5$ & $<25.6$ \\
\hline S97T002016 & & Lower half & $<20.7$ & $<14.4$ & $<17.6$ \\
\hline S97T001699 & $207: 1$ & Lower half & $<71.9$ & $<72.3$ & $<72.1$ \\
\hline S97T001712 & \multirow[t]{2}{*}{$207: 2$} & Upper half & $<71.2$ & $<70.8$ & $<71$ \\
\hline S97T001705 & & Lower half & $<71.3$ & $<71.7$ & $<71.5$ \\
\hline \multicolumn{2}{|l|}{ Mrinis: } & & . & (4) & 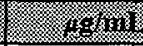 \\
\hline S97T001676 & 205:1 & Drainable liquid & 75.7 & 81.1 & 78.4 \\
\hline S97T001679 & $205: 2$ & Drainable liquid & 72.3 & $73.6^{\circ}$ & 72.9 \\
\hline S97T001692 & $207: 1$ & Drainable liquid & 75.5 & 76.2 & 75.8 \\
\hline
\end{tabular}


HNF-SD-WM-ER-369 Rev. 2

Table B2-32. Tank 241-T-105 Analytical Results: Neodymium (ICP).

\begin{tabular}{|c|c|c|c|c|c|}
\hline $\begin{array}{l}\text { Sominle } \\
\text { NTmber }\end{array}$ & 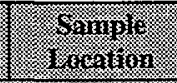 & Gangive & limesili & $\left.83 y_{1}\right)$ & risedin \\
\hline \multicolumn{3}{|c|}{ 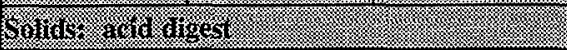 } & 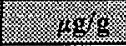 & 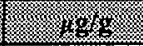 & (2) \\
\hline S97T001687 & \multirow{3}{*}{$\begin{array}{l}205: 2 \\
\text { Clear crystals } \\
\text { Dark crystals }\end{array}$} & Lower half & $<145$ & $<146$ & $<146$ \\
\hline S97T002007 & & Lower half & $<39.2$ & $<63$ & $<51.1$ \\
\hline S97T002016 & & Lower half & $<41.4$ & $<28.9$ & $<35.1$ \\
\hline S97T001699 & $207: 1$ & Lower half & $<144$ & $<145$ & $<145$ \\
\hline S97T001712 & \multirow[t]{2}{*}{$207: 2$} & Upper half & $<142$ & $<142$ & $<142$ \\
\hline S97T001705 & & Lower half & $<143$ & $<143$ & $<143$ \\
\hline Ifonas & & 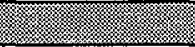 & 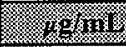 & (4) & (1. \\
\hline S97T001676 & 205:1 & Drainable liquid & $<40.1$ & $<40.1$ & $<40.1$ \\
\hline S97T001679 & $205: 2$ & Drainable liquid & $<40.1$ & $<40.1$ & $<40.1$ \\
\hline S97T001692 & $207: 1$ & Drainable liquid & $<40.1$ & $<40.1$ & $<40.1$ \\
\hline
\end{tabular}

Table B2-33. Tank 241-T-105 Analytical Results: Nickel (ICP).

\begin{tabular}{|c|c|c|c|c|c|}
\hline Sarmily & S Samilo & ( ) & irentis: & 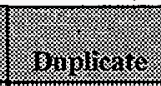 & risin \\
\hline \multicolumn{3}{|c|}{ 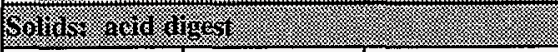 } & 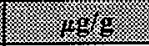 & 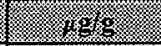 & 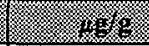 \\
\hline S97T001687 & \multirow{3}{*}{$\begin{array}{l}205: 2 \\
\text { Clear crystals } \\
\text { Dark crystals } \\
\end{array}$} & Lower half & 132 & 141 & 137 \\
\hline S97T002007 & & Lower half & $<7.84$ & $<12.6$ & $<10.2$ \\
\hline S97T002016 & & Lower half. & $<8.27$ & 7.92 & $<8.09$ \\
\hline S97T001699 & $207: 1$ & Lower half & 73.6 & 84.4 & 79 \\
\hline S97T001712 & \multirow{2}{*}{$207: 2$} & Upper half & 63 & 57.8 & 60.4 \\
\hline S97T00.1705 & & Lower half & 66 & 59.4 & 62.7 \\
\hline \multicolumn{3}{|l|}{ 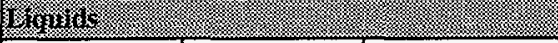 } & $18.48,101$ & (yinin & 8.186 \\
\hline S97T001676 & 205:1 & Drainable liquid & 28.9 & 27.8 & 28.4 \\
\hline S97T001679 & $205: 2$ & Drainable liquid & 38.2 & 38.7 & 38.5 \\
\hline S97T001692 & $207: 1$ & Drainable liquid & 28.3 & 25.9 & 27.1 \\
\hline
\end{tabular}


Table B2-34. Tank 241-T-105 Analytical Results: Phosphorus (ICP).

\begin{tabular}{|c|c|c|c|c|c|}
\hline $\begin{array}{l}\text { Simple } \\
\text { Vuriber }\end{array}$ & Stranjivis & 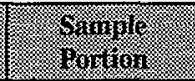 & Thesili & 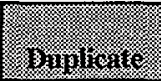 & Hit: in \\
\hline 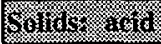 & 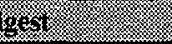 & (3) & , 138 & 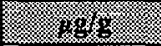 & 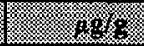 \\
\hline S97T001687 & \multirow{3}{*}{$\begin{array}{l}205: 2 \\
\text { Clear crystals } \\
\text { Dark crystals }\end{array}$} & Lower half & 1,450 & 1,450 & $1,450^{\circ \mathrm{C}: \mathrm{c}}$ \\
\hline S97T002007 & & Lower half & 68,400 & 86,100 & $77,300^{\text {eC:ces }}$ \\
\hline S97T002016 & & Lower half & 355 & 395 & 375 \\
\hline S97T001699 & $207: 1$ & Lower half & 1,430 & 1,400 & 1,420 \\
\hline S97T001712 & \multirow[t]{2}{*}{$207: 2$} & Upper half & 1,460 & 1,480 & 1,470 \\
\hline S97T001705 & & Lower half & 1,800 & 1,560 & $1,680^{\mathrm{QC:c}}$ \\
\hline Virguar & 2 & (2) & (2.8. & $189 \mathrm{mi}$ & 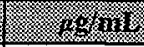 \\
\hline S97T001676 & 205:1 & Drainable liquid & 1,510 & 1,610 & 1,560 \\
\hline S97T001679 & $205: 2$ & Drainable liquid & 1,840 & 1,870 & 1,860 \\
\hline S9TT001692 & $207: 1$ & Drainable liquid & 1,460 & 1,470 & $1,470^{\mathrm{OC} \cdot \mathrm{d}}$ \\
\hline
\end{tabular}

Table B2-35. Tank 241-T-105 Analytical Results: Potassium (ICP).

\begin{tabular}{|c|c|c|c|c|c|}
\hline 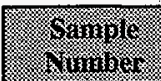 & 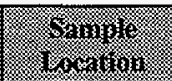 & Quming & 3 & 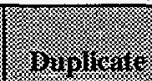 & Ur: \\
\hline \multicolumn{3}{|c|}{ 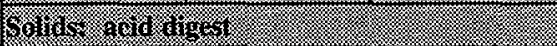 } & 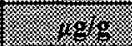 & 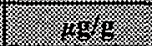 & 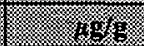 \\
\hline S97T001687 & \multirow{3}{*}{$\begin{array}{l}205: 2 \\
\text { Clear crystals } \\
\text { Dark crystals }\end{array}$} & Lower half & $<723$ & $<729$ & $<726^{\mathrm{QC:d}}$ \\
\hline S97T002007 & & Lower half & $<196$ & $<315$ & $<256$ \\
\hline S97T002016 & & Lower half & $<207$ & $<144$ & $<176$ \\
\hline S97T001699 & $207: 1$ & Lower half & $<719$ & $<723$ & $<721$ \\
\hline S97T001712 & \multirow[t]{2}{*}{$207: 2$} & Upper half & $<712$ & $<708$ & $<710$ \\
\hline S97T001705 & & Lower half & $<713$ & $<717$ & $<715^{\mathrm{QCad}}$ \\
\hline Haring: & 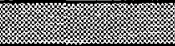 & (2) & $8 \%$ & (6.8. & 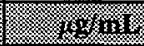 \\
\hline S97T001676 & $205: 1$ & Drainable liquid & 507 & 584 & 546 \\
\hline S97T001679 & $205: 2$ & Drainable liquid & 539 & 514 & 527 \\
\hline S97T001692 & $207: 1$ & Drainable liquid & 546 & 571 & 559 \\
\hline
\end{tabular}


Table B2-36. Tank 241-T-105 Analytical Results: Samarium (ICP).

\begin{tabular}{|c|c|c|c|c|c|}
\hline Sumple & Saring & gample & intsint & Dinplicate & rern \\
\hline \multicolumn{3}{|c|}{ 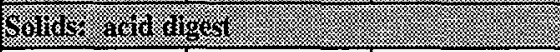 } & . & 18 & 8 \\
\hline S97T001687 & \multirow{3}{*}{$\begin{array}{l}205: 2 \\
\text { Clear crystals } \\
\text { Dark crystals }\end{array}$} & Lower half & $<145$ & $<146$ & $<146$ \\
\hline S97T002007 & & Lower half & $<39.2$ & $<63$ & $<51.1$ \\
\hline S97T002016 & & Lower half & $<41.4$ & $<28.9$ & $<35.1$ \\
\hline S97T001699 & $207: 1$ & Lower half & $<144$ & $<145$ & $<145$ \\
\hline S97T001712 & \multirow{2}{*}{$207: 2$} & Upper half & $<142$ & $<142$ & $<142$ \\
\hline S97T001705 & & Lower half & $<143$ & $<143$ & $<143$ \\
\hline Hignidis: & & & 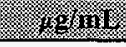 & $3.85 \mathrm{mi}$ & 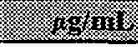 \\
\hline S97T001676 & 205:1 & Drainable liquid & $<40.1$ & $<40.1$ & $<40.1$ \\
\hline S97T001679 & 205:2 & Drainable liquid & $<40.1$ & $<40.1$ & $<40.1$ \\
\hline S97T001692 & 207:1 & Drainable liquid & $<40.1$ & $<40.1$ & $<40.1$ \\
\hline
\end{tabular}

Table B2-37. Tank 241-T-105 Analytical Results: Selenium (ICP).

\begin{tabular}{|c|c|c|c|c|c|}
\hline Sanure & 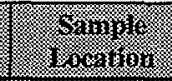 & $\begin{array}{l}\text { somile } \\
\text { gor }\end{array}$ & incsing & 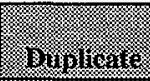 & $86 \ln =$ \\
\hline 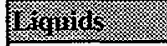 & & 8 & - 24.10 & 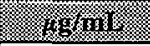 & 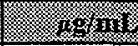 \\
\hline S97T001676 & 205:1 & Drainable liquid & $<40.1$ & $<40.1$ & $<40.1$ \\
\hline S97T001679 & $205: 2$ & Drainable liquid & $<40.1$ & $<40.1$ & $<40.1$ \\
\hline S97T001692 & $207: 1$ & Drainable liquid & $<40.1$ & $<40.1$ & $<40.1$ \\
\hline
\end{tabular}


Table B2-38. Tank 241-T-105 Analytical Results: Silicon (ICP).

\begin{tabular}{|c|c|c|c|c|c|}
\hline $\begin{array}{l}\text { 5qunle } \\
\text { nuner }\end{array}$ & Sampilis & (s) & Ris. & 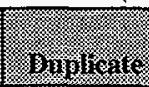 & nern: \\
\hline 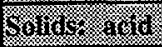 & gert & স্য & 1.4689 & 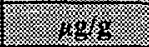 & 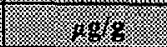 \\
\hline S97T001687 & \multirow{3}{*}{$\begin{array}{l}205: 2 \\
\text { Clear crystals } \\
\text { Dark crystals }\end{array}$} & Lower half & 5,700 & 5,760 & $5,730^{\mathrm{eC}: \mathrm{b}, \mathrm{c}}$ \\
\hline S97T002007 & & Lower half & 1,200 & 4,150 . & $2,680^{\alpha \mathrm{C}: b, \mathrm{~d}, \mathrm{~d}, \mathrm{~h}}$ \\
\hline S97T002016 & & Lower half & 514 & 300 & $4,07^{Q \mathrm{C}: \mathrm{b}, \mathrm{d}, \mathrm{e}}$ \\
\hline S97T001699 & $207: 1$ & Lower half & 3,290 & 2,640 & $2,970^{\mathrm{eC}: b, \mathrm{c}}$ \\
\hline \$97T001712 & \multirow[t]{2}{*}{$207: 2$} & Upper half & 14,700 & 14,400 & $14,600^{\alpha C: b}$ \\
\hline S97T001705 & & Lower half & 18,000 & 1,010 & $9,510^{Q \mathrm{QC}: b, \mathrm{c}, \mathrm{c}, \mathrm{b}}$ \\
\hline 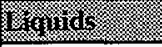 & & 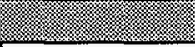 & 18 ini & 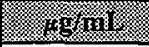 & $1.6 \mathrm{grm}$ \\
\hline S9TT001676 & $205: 1$ & Drainable liquid & 29.5 & 30.6 & 30.1 \\
\hline S97T001679 & $205: 2$ & Drainable liquid & 47.9 & 55.6 & 51.8 \\
\hline S97T001692 & $207: 1$ & Drainable liquid & 42.8 & 43.5 & 43.1 \\
\hline
\end{tabular}

Table B2-39. Tank 241-T-105 Analytical Results: Silver (ICP).

\begin{tabular}{|c|c|c|c|c|c|}
\hline (1) Vimples & (Jimple & 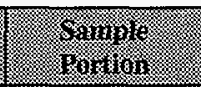 & 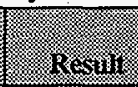 & 630110 & MU:an: \\
\hline \multicolumn{3}{|c|}{ 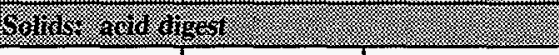 } & 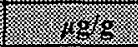 & 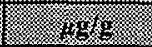 & 1) \\
\hline S97T001687 & \multirow{3}{*}{$\begin{array}{l}205: 2 \\
\text { Clear crystals } \\
\text { Dark crystals }\end{array}$} & Lower half & $44.2^{\circ}$ & 46.9 & $45.5^{\mathrm{QC}: \mathrm{c}}$ \\
\hline S97T002007 & & Lower half & 12.5 & 14.9 & 13.7 \\
\hline S9TT002016 & & Lower half & $<4.14$ & $<2.89$ & $<3.51$ \\
\hline S97T001699 & $207: 1$ & Lower half & 49.2 & 55.4 & 52.3 \\
\hline S97T001712 & \multirow[t]{2}{*}{$207: 2$} & Upper half & $<14.2$ & $<14.2$ & $<14.2$ \\
\hline S97T001705 & & Lower half & $<14.3$ & $<14.3$ & $<14.3$ \\
\hline 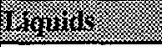 & 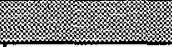 & & . & trgengin & $8.8 \% 111$ \\
\hline S97T001676 & $205: 1$ & Drainable liquid & 6.6 & 7.62 & 7.11 \\
\hline S97T001679 & $205: 2$ & Drainable liquid & 6.15 & 5.89 & 6.02 \\
\hline S97T001692 & $207: 1$ & Drainable liquid & 7.34 & 7.15 & 7.25 \\
\hline
\end{tabular}


Table B2-40. Tank 241-T-105 Analytical Results: Sodium (ICP).

\begin{tabular}{|c|c|c|c|c|c|}
\hline Samiple & 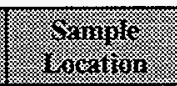 & somple & fermiut & mupling & 18. \\
\hline \multicolumn{3}{|c|}{ 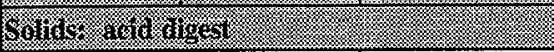 } & 18.898 & (3) & 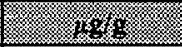 \\
\hline S97T001687 & \multirow{3}{*}{$\begin{array}{l}205: 2 \\
\text { Clear crystals } \\
\text { Dark crystals }\end{array}$} & Lower half & 69,600 & 69,500 & $69,600^{\text {eC:d }}$ \\
\hline S97T002007 & & Lower half & 167,000 & 208,000 & $1.88 \mathrm{E}+05^{\mathrm{QC}: c, e}$ \\
\hline S97T002016 & & Lower half & 3,310 & 3,230 & $3270^{\mathrm{QC}: \mathrm{d}}$ \\
\hline S97T001699 & $207: 1$ & Lower half & 68,900 & 65,700 & 67,300 \\
\hline S97T001712 & \multirow[t]{2}{*}{$207: 2$} & Upper half & 78,600 & 84,500 & 81,600 \\
\hline S97T001705 & & Lower half & 80,600 & 73,500 & $77,100^{\mathrm{ec:c}}$ \\
\hline Mandas & & & f. & 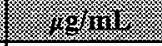 & 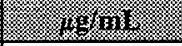 \\
\hline S97T001676 & 205:1 & Drainable liquid & 95,300 & 101,000 & $98,200^{\text {ec:d }}$ \\
\hline S97T001679 & $205: 2$ & Drainable liquid & 90,700 & 91,600 & 91,200 \\
\hline S97T001692 & $207: 1$ & Drainable liquid & 94,000 & 93,700 & $93,900^{\mathrm{eC} ; \mathrm{d}}$ \\
\hline
\end{tabular}

Table B2-41. Tank 241-T-105 Analytical Results: Strontium (ICP).

\begin{tabular}{|c|c|c|c|c|c|}
\hline 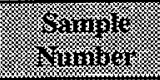 & S.amgl: & (1) & resuln: & 9.1. & 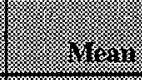 \\
\hline \multicolumn{3}{|c|}{ Solits rar aniest } & 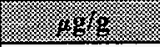 & 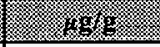 & 8.898 \\
\hline S97T001687 & \multirow{3}{*}{$\begin{array}{l}205: 2 \\
\text { Clear crystals } \\
\text { Dark crystals }\end{array}$} & Lower half & 201 & 204 & 203 \\
\hline S97T002007 & & Lower half & $<3.92$ & $<6.3$ & $<5.11$ \\
\hline S97T002016 & & Lower half & 8 & 6.66 & 7.33 \\
\hline S97T001699 & $207: 1$ & Lower half & 120 & 131 & 126 \\
\hline S97T001712 & \multirow{2}{*}{$207: 2$} & Upper half & 191 & 196 & 194 \\
\hline S97T001705 & & Lower half & 299 & 276 & 288 \\
\hline \multicolumn{3}{|l|}{ (1) } & (1.8. & $(40 \mathrm{~g} / \mathrm{mil}$ & $8.48 \sin$ \\
\hline S97T001676 & 205:1 & Drainable liquid & $<4.01$ & $<4.01$ & $<4.01$ \\
\hline S97T001679 & $205: 2$ & Drainable liquid & $<4.01$ & $<4.01$ & $<4.01$ \\
\hline S97T001692 & $207: 1$ & Drainable liquid & $<4.01$ & $<4.01$ & $<4.01$ \\
\hline
\end{tabular}


Table B2-42. Tank 241-T-105 Analytical Results: Sulfur (ICP).

\begin{tabular}{|c|c|c|c|c|c|}
\hline 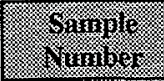 & $\begin{array}{l}\text { Sanvolis } \\
\text { Uogation }\end{array}$ & romiole & Resint & Driplesie & $\sqrt{1780}$ \\
\hline \multicolumn{3}{|c|}{ Soliter arid argest } & 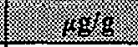 & $f_{2}=8.85$ & $\sqrt{18}$ \\
\hline S97T001687 & \multirow{3}{*}{$\begin{array}{l}205: 2 \\
\text { Clear crystals } \\
\text { Dark crystals }\end{array}$} & Lower half & 3,100 & 3,100 & 3,100 \\
\hline S97T002007 & & Lower half & 80.6 & 73.8 & 77.2 \\
\hline S97T002016 & & Lower half & 153 & 131 & 142 \\
\hline S97T001699 & $207: 1$ & Lower hálf & 3,540 & 3,410 & 3,480 \\
\hline S97T001712 & \multirow{2}{*}{$207: 2$} & Upper half & 3,170 & 3,210 & 3,190 \\
\hline S97T001705 & & Lower half & 2,950 & 2,820 & 2,890 \\
\hline Ifigids & : & . & 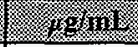 & 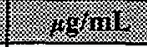 & . \\
\hline S97T001676 & 205:1 & Drainable liquid & 5,520 & 5,840 & 5,680 \\
\hline S97T001679 & $205: 2$ & Drainable liquid & 5,130 & 5,200 & 5,170 \\
\hline S97T001692 & 207:1 & Drainable liquid & 5,510 & 5,430 & $5,470^{\mathrm{QC:d}}$ \\
\hline
\end{tabular}

Table B2-43. Tank 241-T-105 Analytical Results: Thallium (ICP).

\begin{tabular}{|c|c|c|c|c|c|}
\hline Symole & $\frac{1}{3}$ & 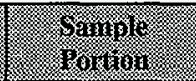 & I revin & (8) & Matis \\
\hline 5011658 ard & Ifts: & 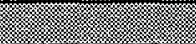 & 8.88 & 1898 & 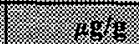 \\
\hline S97T001687 & \multirow{3}{*}{$\begin{array}{l}205: 2 \\
\text { Clear crystals } \\
\text { Dark crystals }\end{array}$} & Lower half & 432 & 394 & 413 \\
\hline S97T002007 & & Lower half & $<78.4$ & $<126$ & $<102$ \\
\hline S97T002016 & & Lower half & $<82.7$ & $<57.7$ & $<70.2$ \\
\hline S97T001699 & $207: 1$ & Lower half & $<288$ & $<289$ & $<289$ \\
\hline S97T001712 & \multirow[t]{2}{*}{$207: 2$} & Upper half & $<285$ & $<283$ & $<284$ \\
\hline S97T001705 & & Lower half & $<285$ & $<287$ & $<286$ \\
\hline Siringis: & ; & 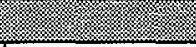 & . & - $19 \mathrm{gin}$ & (1) \\
\hline S97T001676 & $205: 1$ & Drainable liquid & $<80.2$ & $<80.2$ & $<80.2$ \\
\hline S97T001679 & $205: 2$ & Drainable liquid & $<80.2$ & $<80.2$ & $<80.2$ \\
\hline S97T001692 & $207: 1$ & Drainable liquid & $<80.2$ & $<80.2$ & $<80.2$ \\
\hline
\end{tabular}


Table B2-44. Tank 241-T-105 Analytical Results: Titanium (ICP).

\begin{tabular}{|c|c|c|c|c|c|}
\hline $\begin{array}{l}\text { Simule } \\
\text { Vimber }\end{array}$ & $\begin{array}{l}\text { Sample: } \\
\text { Soratiog: }\end{array}$ & Simple & tesing & Briniliedter & Vrear \\
\hline 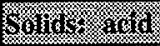 & gest & (4) & 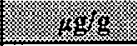 & 8 & : 196 \\
\hline S97T001687 & \multirow{3}{*}{$\begin{array}{l}205: 2 \\
\text { Clear crystals } \\
\text { Dark crystals }\end{array}$} & Lower half & 46.8 & 50.4 & 48.6 \\
\hline S97T002007 & & Lower half & $<3.92$ & $<6.3$ & $<5.11$ \\
\hline S97T002016 & & Lower half & $<4.14$ & $<2.89$ & $<3.51$ \\
\hline S97T001699 & $207: 1$ & Lower half & 32.8 & 33.3 & 33 \\
\hline S97T001712 & \multirow[t]{2}{*}{$207: 2$} & Upper half & $<14.2$ & $<14.2$ & $<14.2$ \\
\hline S97T001705 & & Lower half & 18.6 & 14.4 & $16.5^{\propto C: e}$ \\
\hline \multicolumn{3}{|l|}{ Lainias } & $1.89 .1 \mathrm{in}$ & 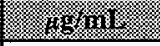 & (19.1nit: \\
\hline S97T001676 & 205:1 & Drainable liquid & $<4.01$ & $<4.01$ & $<4.01$ \\
\hline S97T001679 & $205: 2$ & Drainable liquid & $<4.01$ & $<4.01$ & $<4.01$ \\
\hline S97T001692 & 207:1 & Drainable liquid & $<4.01$ & $<4.01$ & $<4.01$ \\
\hline
\end{tabular}

Table B2-45. Tank 241-T-105 Analytical Results: Total Uranium (ICP).

\begin{tabular}{|c|c|c|c|c|c|}
\hline$\frac{64 \mathrm{~min}}{\mathrm{man}}$ & 5. & g. & restili: & Binilizative & Mrati: \\
\hline \multicolumn{3}{|c|}{ 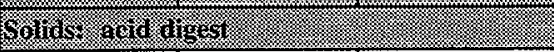 } & 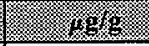 & 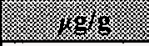 & 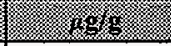 \\
\hline S97T001687 & \multirow{3}{*}{$\begin{array}{l}205: 2 \\
\text { Clear crystals } \\
\text { Dark crystals }\end{array}$} & Lower half & 11,600 & 12,000 & 11,800 \\
\hline S97T002007 & & Lower half & $<196$ & $<315$ & $<256$ \\
\hline S97T002016 & & Lower half & 336 & 219 & $278^{\mathrm{QC}: \mathrm{e}}$ \\
\hline S97T001699 & $207: 1$ & Lower half & 5,210 & 5,840 & 5,530 \\
\hline S97T001712 & \multirow[t]{2}{*}{$207: 2$} & Upper half & 1,550 & 1,490 & 1,520 \\
\hline S97T001705 & & Lower half & $<713$ & $<717$ & $<715$ \\
\hline (1) & & & $10.8 \mathrm{nil}$ & 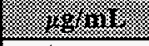 & 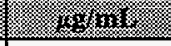 \\
\hline S97T001676 & $205: 1$ & Drainable liquid & $<200$ & $<200$ & $<200$ \\
\hline S97T001679 & $205: 2$ & Drainable liquid & $<200$ & $<200$ & $<200$ \\
\hline S97T001692 & $207: 1$ & Drainable liquid & $<200$ & $<200$ & $<200$ \\
\hline
\end{tabular}


Table B2-46. Tank 241-T-105 Analytical Results: Vanadium (ICP).

\begin{tabular}{|c|c|c|c|c|c|}
\hline Sanole: & 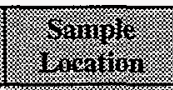 & Sampi & Ricsin: & 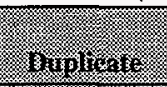 & 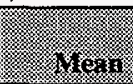 \\
\hline 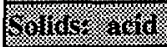 & 1458 & 4 & $8.8 \mathrm{~g}, 8$. & 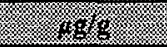 & .68 \\
\hline S97T001687 & \multirow{3}{*}{$\begin{array}{l}205: 2 \\
\text { Clear crystals } \\
\text { Dark crystals }\end{array}$} & Lower half & $<72.3$ & $<72.9$ & $<72.6$ \\
\hline S97T002007 & & Lower half & 29.7 & $<31.5$ & $<30.6$ \\
\hline S97T002016 & & Lower half & $<20.7$ & $<14.4$ & $<17.6$ \\
\hline S97T001699 & $207: 1$ & Lower half & $<71.9$ & $<72.3$ & $<72.1$ \\
\hline S97T001712 & \multirow[t]{2}{*}{$207: 2$} & Upper half & $<71.2$ & $<70.8$ & $<71$ \\
\hline S97T001705 & & Lower half & $<71.3$ & $<71.7$ & $<71.5$ \\
\hline \multicolumn{3}{|l|}{ Proutas } & $14 \mathrm{~g}$ in: & 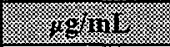 & . \\
\hline S97T001676 & 205:1 & Drainable liquid & $<20.1$ & $<20.1$ & $<20.1$ \\
\hline S97T001679 & 205:2 & Drainable liquid & $<20.1$ & $<20.1$ & $<20.1$ \\
\hline S97T001692 & $207: 1$ & Drainable liquid & $<20.1$ & $<20.1$ & $<20.1$ \\
\hline
\end{tabular}

Table B2-47. Tank 241-T-105 Analytical Results: Zinc (ICP).

\begin{tabular}{|c|c|c|c|c|c|}
\hline 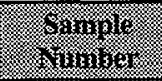 & Sominge & 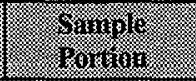 & isesing & ryultiser & Midu \\
\hline Som ms a ara & (3) $=51$ & 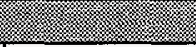 & - & 1.2898 & (1) \\
\hline S97T001687 & \multirow{3}{*}{$\begin{array}{l}205: 2 \\
\text { Clear crystals } \\
\text { Dark crystals }\end{array}$} & Lower half & 102 & 140 & $121^{\text {ec:e }}$ \\
\hline S97T002007 & & Lower half & 29.1 & 41.4 & $35.3^{\mathrm{ec}: 0}$ \\
\hline S97T002016 & & Lower half & 108 & 79 & $93.5^{\mathrm{OC}: \mathrm{c}}$ \\
\hline S97T001699 & $207: 1$ & Lower half & 152 & 146 & 149 \\
\hline S97T001712 & \multirow[t]{2}{*}{$207: 2$} & Upper half & 225 & 202 & 214 \\
\hline S97T001705 & & Lower half & 765 & 692 & 729 \\
\hline rivining & 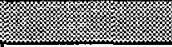 & 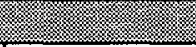 & 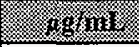 & 4.183 .111 & 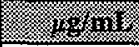 \\
\hline S97T001676 & $205: 1$ & Drainable liquid & $<4.01$ & $<4.01$ & $<4.01$ \\
\hline S97T001679 & 205:2 & Drainable liquid & $<4.01$ & $<4.01$ & $<4.01$ \\
\hline S97T001692 & $207: 1$ & Drainable liquid & $<4.01$ & $<4.01$ & $<4.01$ \\
\hline
\end{tabular}


Table B2-48. Tank 241-T-105 Analytical Results: · Zirconium (ICP).

\begin{tabular}{|c|c|c|c|c|c|}
\hline Sumples & Sorming & 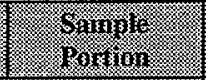 & Rresuis & Dinelictro & Hrear : \\
\hline bintivs ado & 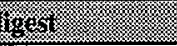 & 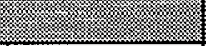 & 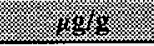 & 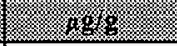 & 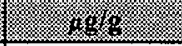 \\
\hline S97T001687 & \multirow{3}{*}{$\begin{array}{l}205: 2 \\
\text { Clear crystals } \\
\text { Dark crystals }\end{array}$} & Lower half & 94.4 & 56.8 & $75.6^{\mathrm{QC}: c, \mathrm{c}}$ \\
\hline S97T002007 & & Lower half & 4.66 & 9.28 & $6.97^{\mathrm{QC:c,0}}$ \\
\hline S97T002016 & & Lower half & 4.56 & 4.47 & $4.52^{\mathrm{QC:c}}$ \\
\hline S97T001699 & $207: 1$ & Lower half & 60.8 & 26.4 & $43.6^{\mathrm{QC}: \mathrm{e}}$ \\
\hline S97T001712 & \multirow[t]{2}{*}{$207: 2$} & Upper half & 101 & 80.5 & $90.8^{\mathrm{QC}: 0}$ \\
\hline S97T001705 & & Lower half & $<14.3$ & $<14.3$ & $<14.3^{\alpha \mathrm{\alpha}: c}$ \\
\hline \multicolumn{3}{|l|}{ Mrgmids } & FV: & 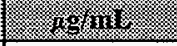 & 38 inis: \\
\hline S97T001676 & 205:1 & Drainable liquid & $<4.01$ & $<4.01$ & $<4.01$ \\
\hline S97T001679 & $205: 2$ & Drainable liquid & $<4.01$ & $<4.01$ & $<4.01$ \\
\hline S97T001692 & $207: 1$ & Drainable liquid & $<4.01$ & $<4.01$ & $<4.01$ \\
\hline
\end{tabular}

Table B2-49. Tank 241-T-105 Analytical Results: Bromide (IC). ${ }^{1}$

\begin{tabular}{|c|c|c|c|c|c|}
\hline 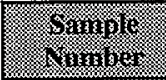 & 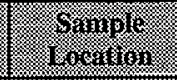 & 501018 & ir. & 3) & jera \\
\hline 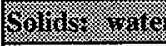 & inistist & 8 & 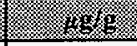 & $10 \mathrm{~g} 8$ & .808. \\
\hline S97T001688 & \multirow{3}{*}{$\begin{array}{l}205: 2 \\
\text { Clear crystals } \\
\text { Dark crystals }\end{array}$} & Lower half & 1,090 & 1,060 & 1,080 \\
\hline S97T002008 & & Lower half & $<782$ & $<2,080$ & $<1,430$ \\
\hline S97T002017 & & Lower half & 522 & $<454$ & $<488$ \\
\hline S97T001700 & $207: 1$ & Lower half & $<528$ & $<520$ & $<524$ \\
\hline S97T001713 & \multirow[t]{2}{*}{$207: 2$} & Upper half & 455 & 442 & 449 \\
\hline \$97T001706 & & Lower half & 1,030 & 985 & 1,010 \\
\hline 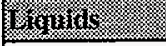 & & & 1,8 (6) & $184 \mathrm{~min}$ & (3) \\
\hline S97T001676 & 205:1 & Drainable liquid & $<1,280$ & $<1,280$ & $<1,280$ \\
\hline S97T001679 & $205: 2$ & Drainable liquid & 1,780 & 1,800 & 1,790 \\
\hline S97T001692 & $207: 1$ & Drainable liquid & $<265$ & $<265$ & $<265$ \\
\hline
\end{tabular}

Note:

${ }^{1}$ Lithium bromide was used as tracer fluid. Bṛomide is not a constituent in tank waste. 
Table B2-50. Tank 241-T-105 Analytical Results: Chloride (IC).

\begin{tabular}{|c|c|c|c|c|c|}
\hline Prampic & Solmplerins & 9.mple & 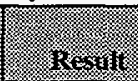 & Buplitare & is \\
\hline \multicolumn{3}{|c|}{ 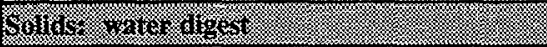 } & $8.18 .8 \%$ & $1,16 \mathrm{gg}$ & 8 \\
\hline S97T001688 & \multirow{3}{*}{$\begin{array}{l}205: 2 \\
\text { Clear crystals } \\
\text { Dark crystals }\end{array}$} & Lower half & 418 & 379 & 399 \\
\hline S97T002008 & & Lower half & 298 & 342 & 320 \\
\hline S97T002017 & & Lower half & 75 & 202 & $138^{\mathrm{QC:e}}$ \\
\hline S97T001700 & $207: 1$ & Lower half & 578 & 400 & $489^{e c: e}$ \\
\hline$\$ 97 \mathrm{~T} 001713$ & \multirow[t]{2}{*}{$207: 2$} & Upper half & 384 & 398 & 391 \\
\hline \$97T001706 & & Lower half & 349 & 316 & 332 \\
\hline 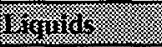 & & & (2) & (1) & $f_{125}$ \\
\hline S97T001676 & 205:1 & Drainable liquid & 341 & 373 & 357 \\
\hline S97T001679 & $205: 2$ & Drainable liquid & 319 & 305 & 312 \\
\hline S97T001692 & $207: 1$ & Drainable liquid & 595 & 584 & 589 \\
\hline
\end{tabular}

Table B2-51. Tank 241-T-105 Analytical Results: Fluoride (IC),

\begin{tabular}{|c|c|c|c|c|c|}
\hline 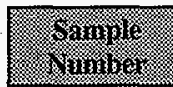 & 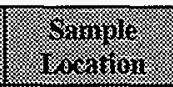 & 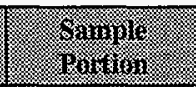 & (8) & (2) & 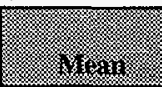 \\
\hline \multicolumn{3}{|c|}{ Soriaks vare ang } & 45 & 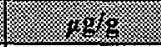 & 8.96 \\
\hline S97T001688 & \multirow{3}{*}{$\begin{array}{l}205: 2 \\
\text { Clear crystals } \\
\text { Dark crystals }\end{array}$} & Lower half & 499 & 454 & 477 \\
\hline S97T002008 & & Lower half & 22,700 & 23,000 & 22,800 \\
\hline S97T002017 & & Lower half & 153 & 194. & $174^{\mathrm{QC}: 0}$ \\
\hline S97T001700 & $207: 1$ & Lower half & 421 & 381 & 401 \\
\hline S97T001713 & \multirow[t]{2}{*}{$207: 2$} & Upper half & 556 & 562 & 559 \\
\hline S97T001706 & & Lower half & 502 & 464 & 483 \\
\hline \multicolumn{2}{|l|}{ IIrivins } & & $858 . \mathrm{sil}$ & 3.1313: & 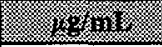 \\
\hline S97T001676 & $205: 1$ & Drainable liquid & 638 & 624 & 631 \\
\hline S97T001679 & $205: 2$ & Drainable liquid & 660 & 596 & 628 \\
\hline S97T001692 & 207:1 & Drainable liquid & 633 & 615 & 624 \\
\hline
\end{tabular}


Table B2-52. Tank 241-T-105 Analytical Results: Nitrate (IC).

\begin{tabular}{|c|c|c|c|c|c|}
\hline Sumiles & Shanilis & 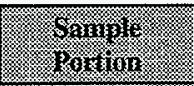 & mesuls & Mupirest: & 1. \\
\hline \multicolumn{3}{|c|}{ 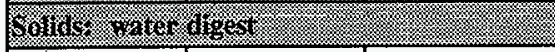 } & 8.96 & 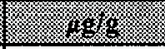 & 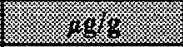 \\
\hline S97T001688 & \multirow{3}{*}{$\begin{array}{l}205: 2 \\
\text { Clear crystals } \\
\text { Dark crystals }\end{array}$} & Lower half & 25,600 & 24,700 . & 25,200 \\
\hline S97T002008 & & Lower half & 1,520 & 3,910 & $2,720^{\mathrm{QC:e}}$ \\
\hline \$97T002017 & & Lower half & 1,660 & 2,210 & $1,930^{\mathrm{QC:c}}$ \\
\hline S9TT001700 & $207: 1$ & Lower half & 25,800 & 25,600 & 25,700 \\
\hline S97T001713 & \multirow[t]{2}{*}{$207: 2$} & Upper half & 24,800 & 24,500 & 24,600 \\
\hline S97T001706 & & Lower half & 22,200 & 20,900 & 21,600 \\
\hline \multicolumn{3}{|l|}{ Ecinids: } & (3) & $3.84 \mathrm{nI}$ & . \\
\hline S97T001676 & 205:1 & Drainable liquid & 39,000 & 38,800 & 38,900 \\
\hline S97T001679 & $205: 2$ & Drainable liquid & 36,800 & 36,400 & 36,600 \\
\hline S97T001692 & $207: 1$ & Drainable liquid & 35,800 & 35,900 & 35,900 \\
\hline
\end{tabular}

Table B2-53. Tank 241-T-105 Analytical Results: Nitrite (IC).

\begin{tabular}{|c|c|c|c|c|c|}
\hline STinilo & 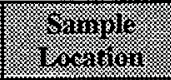 & Sormple & $\sqrt{1}+2.11$ & 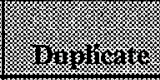 & 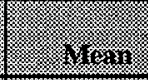 \\
\hline \multicolumn{3}{|c|}{ 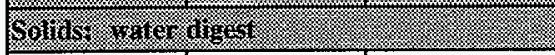 } & 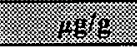 & 1., & $18 \mathrm{gg}$ \\
\hline S97T001688 & \multirow{3}{*}{$\begin{array}{l}205: 2 \\
\text { Clear crystals } \\
\text { Dark crystals }\end{array}$} & Lower half & 37,600 & 35,700 & 36,700 \\
\hline S97T002008 & & Lower half & 1,300 & 2,990 & $2,150^{\text {QC:e }}$ \\
\hline S97T002017 & & Lower half & 1,610 & 2,470 & $2,040^{\mathrm{eC}: \mathrm{c}}$ \\
\hline S97T001700 & $207: 1$ & Lower half & 37,700 & 36,800 . & 37,300 \\
\hline S97T001713 & \multirow[t]{2}{*}{$207: 2$} & Upper half & 34,200 & 34,000 & 34,100 \\
\hline S97T001706 & & Lower half & 32,000 & 29,800 & 30,900 \\
\hline \multicolumn{3}{|l|}{ Sivunins } & 8.62 .111 & 18. & 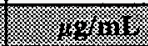 \\
\hline S97T001676 & 205:1 & Drainable liquid & 56,900 & 58,700 & 57,800 \\
\hline S97T001679 & 205:2 & Drainable liquid & 56,000 & 53,800 & 54,900 \\
\hline S97T001692 & 207:1 & Drainable liquid & 51,500 & 51,700 & 51,600 \\
\hline
\end{tabular}


Table B2-54. Tank 241-T-105 Analytical Results: Phosphate (IC).

\begin{tabular}{|c|c|c|c|c|c|}
\hline 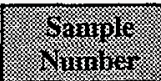 & Somingle & Saringle: & Res = all & Duplicate & Vrear: \\
\hline Suling vistit & (iogest & (4) & 3. & 8,498 & 8.8 \\
\hline S97T001688 & \multirow{3}{*}{$\begin{array}{l}205: 2 \\
\text { Clear crystals } \\
\text { Dark crystals }\end{array}$} & Lower half & 4,010 & 3,790 & 3,900 \\
\hline S97T002008 & & Lower half & 221,000 & 231,000 & 226,000 \\
\hline S97T002017 & & Lower half & 1,430 & 2,290 & $1,860^{\text {eC:e }}$ \\
\hline S97T001700 & $207: 1$ & Lower half & 2,920 & 3,100 & 3,010 \\
\hline S97T001713 & \multirow[t]{2}{*}{$207: 2$} & Upper half & 3,390 & 3,370 & 3,380 \\
\hline S97T001706 & & Lower half & 2,710 & 2,900 & 2,810 \\
\hline I.ting & ; & 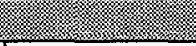 & $\left\{\begin{array}{l}1 \\
z\end{array}\right.$ & pog in: & 8 ; \\
\hline S97T001676 & $205: 1$ & Drainable liquid & 4,600 & 4,440 & 4,520 \\
\hline S97T001679 & $205: 2$ & Drainable liquid & 5,230 & 6,010 & 5,620 \\
\hline S97T001692 & $207: 1$ & Drainable liquid & 3,910 & 3,720 & 3,820 \\
\hline
\end{tabular}

Table B2-55. Tank 241-T-105 Analytical Results: Sulfate (IC).

\begin{tabular}{|c|c|c|c|c|c|}
\hline vininges & 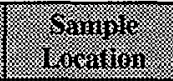 & 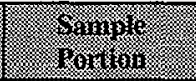 & restisis & 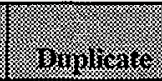 & (1) \\
\hline 50 TIS & (1) & 4 & 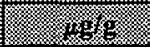 & 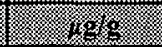 & 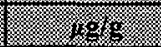 \\
\hline S97T001688 & \multirow{3}{*}{$\begin{array}{l}205: 2 \\
\text { Clear crystals } \\
\text { Dark crystals }\end{array}$} & Lower half & 10,600 & 10,600 & 10,600 \\
\hline S97T002008 & & Lower half & 1,620 & 2,330 & $1980^{\mathrm{QC}: \mathrm{e}}$ \\
\hline S97T002017 & & Lower half & 666 & 1,120 & $893^{\mathrm{CC}: \mathrm{c}}$ \\
\hline S97T001700 & $207: 1$ & Lower half & 11,100 & 10,800 & 11,000 \\
\hline \$97T001713 & \multirow[t]{2}{*}{$207: 2$} & Upper half & 9,400 & 9,360 & 9,380 \\
\hline$\$ 977001706$ & & Lower half & 8,170 & 7,790 & 7,980 \\
\hline Tinar & (:- & 48 & - 8 gthin: & (1.6.1.1. & 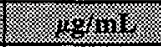 \\
\hline S97T001676 & 205:1 & Drainable liquid & 17,100 & 17,200 & 17,100 \\
\hline \$97T001679 & 205:2 & Drainable liquid & 16,900 & 17,100 & 17,000 \\
\hline S97T001692 & $207: 1$ & Drainable liquid & 14,400 & 14,300 & 14,400 \\
\hline
\end{tabular}


Table B2-56. Tank 241-T-105 Analytical Results: Oxalate (IC).

\begin{tabular}{|c|c|c|c|c|c|}
\hline 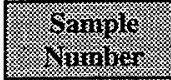 & 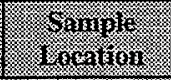 & Sampic & Resint & Moulicale & Yrosin \\
\hline \multicolumn{3}{|c|}{ 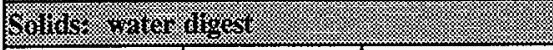 } & 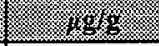 & 18698 & 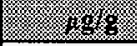 \\
\hline S97T001688 & \multirow{3}{*}{$\begin{array}{l}205: 2 \\
\text { Clear crystals } \\
\text { Dark crystals }\end{array}$} & Lower half & $<444$ & $<447$ & $<446$ \\
\hline S97T002008 & & Lower half & $<657$ & $<1,740$ & $<1,200$ \\
\hline S97T002017 & & Lower half & 598 & $<382$ & $<490$ \\
\hline S97T001700 & $207: 1$ & Lower half & $<444$ & $<437$ & $<440$ \\
\hline S97T001713 & \multirow[t]{2}{*}{$207: 2$} & Upper half & 5,150 & 4,870 & 5,010 \\
\hline S97T001706 & & Lower half & $<436$ & $<437$ & $<436$ \\
\hline Ironias: & & & 8.96131. & 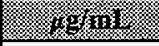 & 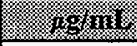 \\
\hline S97T001676 & 205:1 & Drainable liquid & $<1,070$ & $<1,070$ & $<1,070$ \\
\hline S97T001679 & $205: 2$ & Drainable liquid & $<1,070$ & $<1,070$ & $<1,070$ \\
\hline S97T001692 & $207: 1$ & Drainable liquid & 1,240 & 1,230 & 1,230 \\
\hline
\end{tabular}

Table B2-57. Tank 241-T-105 Analytical Results: Bulk Density.

\begin{tabular}{|c|c|c|c|c|c|}
\hline SWIIIIII) & 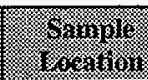 & Shomile & intin & mintiste & 18 \\
\hline Solits & r & 4 & g.min & : & 8710 \\
\hline S9TT001685 & 205:2 & Lower half & 1.34 & $\mathrm{n} / \mathrm{a}$ & 1.34 \\
\hline S97T001695 & $207: 1$ & Lower half & 1.32 & $\mathrm{n} / \mathrm{a}$ & 1.32 \\
\hline S97T001708 & \multirow[t]{2}{*}{ 207:2 } & Upper half & 1.49 & $\mathrm{n} / \mathrm{a}$ & 1.49 \\
\hline S97T001702 & & Lower half & 1.53 & $n / a$ & 1.53 \\
\hline
\end{tabular}


Table B2-58. Tank 241-T-105 Analytical Results: Percent Water (TGA).

\begin{tabular}{|c|c|c|c|c|c|}
\hline $\begin{array}{l}\text { 6rinule } \\
\text { vininier }\end{array}$ & 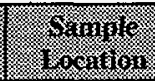 & $\begin{array}{l}\text { Thringte } \\
\text { Portion }\end{array}$ & resiul & loubtache & Meru \\
\hline I.jins & (1) & স্যু & 183 & l( & 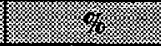 \\
\hline S97T001685 & $205: 2$ & Lower half & 69 & 55.5 & 62.3 \\
\hline S97T001697 & 207:1 & Lower half & 61.6 & 71.7 & 66.7 \\
\hline \$97T001709 & \multirow[t]{2}{*}{$207: 2$} & Upper half & 54.7 & 49.2 & 51.9 \\
\hline S97T001703 & & Lower half & 56.2 & 53.8 & 55 \\
\hline \multicolumn{2}{|c|}{ 2. } & & 8 & 10 & (2) \\
\hline S97T001675 & 205:1 & Drainable liquid & 76.1 & 76.3 & 76.2 \\
\hline S97T001679 & $205: 2$ & Drainable liquid & 76.9 & 76.9 & 76.9 \\
\hline
\end{tabular}

Table B2-59. Tank 241-T-105 Analytical Results: Specific Gravity.

\begin{tabular}{|c|c|c|c|c|c|}
\hline S Sininile & yoringle & 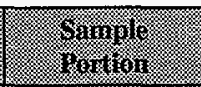 & 18 & 3001158 & 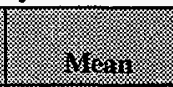 \\
\hline Iirinings & 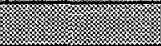 & "1. & 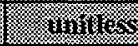 & 1) & miners \\
\hline S97T001675 & $205: 1$ & Drainable liquid & 1.17 & 1.18 & 1.17 \\
\hline S97T001679 & $205: 2$ & Drainable liquid & 1.2 & 1.19 & 1.2 \\
\hline
\end{tabular}

Table B2-60. Tank 241-T-105 Analytical Results: Total Alpha.

\begin{tabular}{|c|c|c|c|c|c|}
\hline Surivis & 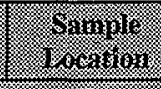 & sangle & iresin: & 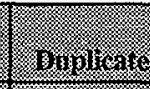 & 18.7. \\
\hline Mranins & & $\sqrt{1.28}$ & 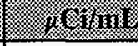 & 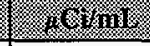 & 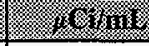 \\
\hline S97T001675 & 205:1 & Drainable liquid & 0.00405 & 0.00234 & $0.0032^{\mathrm{QC}: c}$ \\
\hline S97T001679 & $205: 2$ & Drainable liquid & $<0.00177$ & $<0.00348$ & $<0.00263$ \\
\hline 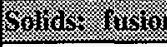 & & & 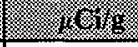 & 1 & $4+\sqrt{8}$ \\
\hline S97T001686 & 205:2 & Lower half & 0.539 & 0.553 & 0.546 \\
\hline S97T001698 & $207: 1$ & Lower half & 0.307 & 0.269 & 0.288 \\
\hline S97T001711 & \multirow[t]{2}{*}{$207: 2$} & Upper half & 0.566 & 0.587 & 0.577 \\
\hline S97T001704 & & Lower half & 0.141 & 0.151 & 0.146 \\
\hline
\end{tabular}




\section{ANALYTICAL RESULTS}

Table B2-61. Tank 241-T-105 Analytical Results: Cesium (Atomic Absorption).

\begin{tabular}{|c|c|c|c|c|c|}
\hline Somile & sarnil & $\begin{array}{l}\text { Sampli } \\
\text { Yourion }\end{array}$ & resill: & unintionis & ris: \\
\hline \multicolumn{3}{|c|}{ 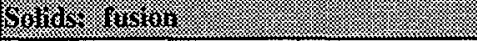 } & 2.1848 & . & r \\
\hline $25-6793$ & $53: 1$ & Whole & $<700$ & $<700$ & $<700^{\mathrm{QC}: \mathrm{c}}$ \\
\hline $33-6793$ & $54: 1$ & Whole & $<1,000$ & $<1,000$ & $<1,000^{\text {eC:a }}$ \\
\hline \multicolumn{3}{|c|}{ 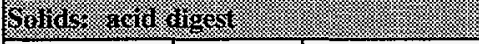 } & 488 & 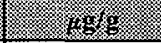 & $v_{g} / 8$ \\
\hline $25-8794$ & $53: 1$ & Whole & $<140$ & $<140$ & $<140^{\text {QC: }:}$ \\
\hline 33-8794 & $54: 1$ & Whole & $<200$ & $<200$ & $<200$ \\
\hline
\end{tabular}

Table B2-62. Tank 241-T-105 Analytical Results: Mercury (Cold Vapor Atomic Absorption).

\begin{tabular}{|c|c|c|c|c|c|}
\hline Sirnjole & s sinuple & 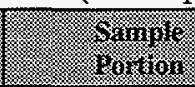 & iresull & 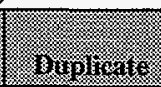 & inenin \\
\hline \multicolumn{3}{|c|}{ Sorids a rif bigest: } & (1). & 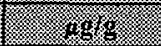 & (2) \\
\hline $25-5798$ & $53: 1$ & Whole & 41 & 32.7 & $36.85^{\mathrm{QC}: e}$ \\
\hline $33-5798$ & $54: 1$ & Whole & 11.8 & 10.2 & $11^{\mathrm{QC:c}}$ \\
\hline
\end{tabular}


Table B2-63. Tank 241-T-105 Analytical Results: Aluminum (ICP).

\begin{tabular}{|c|c|c|c|c|c|}
\hline S S & 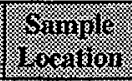 & 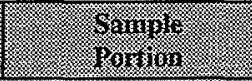 & ilenilit. & (Dikn) & t. \\
\hline \multicolumn{3}{|c|}{ 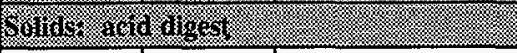 } & 4898 & (3) & 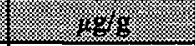 \\
\hline $25-8755$ & $53: 1$ & Whole & 30,000 & 32,700 & $31,350^{\mathrm{QCOb}}$ \\
\hline $33-8755$ & \multirow[t]{3}{*}{$54: 1$} & Whole & $1.52 \mathrm{E}+05$ & $1.55 \mathrm{E}+05$ & $1.54 \mathrm{E}+05^{\mathrm{QC}: \mathrm{b}, \mathrm{d}}$ \\
\hline $41-8755$ & & Homogenization test & $1.84 \mathrm{E}+05$ & $1.73 \mathrm{E}+05$ & $1.79 \mathrm{E}+05^{\mathrm{eC}: \mathrm{b}, \mathrm{d}}$ \\
\hline $40-8755$ & & Homogenization test & $1.86 \mathrm{E}+05$ & $1.90 \mathrm{E}+05$ & $1.88 \mathrm{E}+05^{\mathrm{QC}: \mathrm{b}}$ \\
\hline \multicolumn{3}{|c|}{ Solvis ristin } & 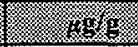 & 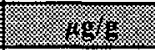 & $\mathrm{l}_{2}$ \\
\hline $25-6775$ & $53: 1$ & Whole & 37,400 & 41,100 & $39,250^{\mathrm{QC:d}}$ \\
\hline $33-6755$ & $54: 1$ & Whole & $1.52 \mathrm{E}+05$ & $1.50 \mathrm{E}+05$ & $1.51 \mathrm{E}+05^{\mathrm{QC} d \mathrm{~d}}$ \\
\hline \multicolumn{3}{|c|}{ 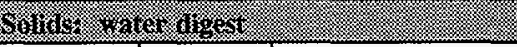 } & 3.898. & 3.1456 & 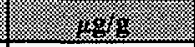 \\
\hline $25-7755$ & $53: 1$ & Whole & 152 & 154 & 153 \\
\hline 33-7755 & $54: 1$ & Whole & 348 & 476 & $412^{\mathrm{QC}: 0}$ \\
\hline
\end{tabular}

Table B2-64. Tank 241-T-105 Analytical Results: Antimony (ICP).

\begin{tabular}{|c|c|c|c|c|c|}
\hline 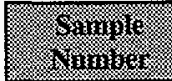 & Sormolo & 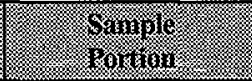 & (nesin: & 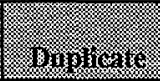 & 14:8ir: \\
\hline \multicolumn{3}{|c|}{ 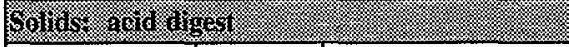 } & 33 & 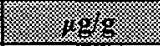 & 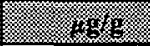 \\
\hline $25-8755$ & $53: 1$ & Whole & $<126$ & $<125$ & $<125.5^{\mathrm{QC}: \Omega}$ \\
\hline $33-8755$ & \multirow[t]{3}{*}{$54: 1$} & Whole & $<128$ & $<128$ & $<128^{\mathrm{QC:a}}$ \\
\hline $41-8755$ & & Homogenization test & $<127$ & $<128$ & $<127.5$ \\
\hline $40-8755$ & & Homogenization test & $<129$ & $<129$ & $<129$ \\
\hline \multicolumn{3}{|c|}{ 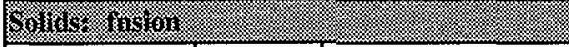 } & 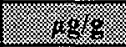 & 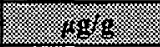 & 8 \\
\hline $25-6775$ & $53: 1$ & Whole & $<103$ & $<104$ & $<103.5$ \\
\hline $33-6755$ & $54: 1$ & Whole & $<105$ & $<103$ & $<104$ \\
\hline \multicolumn{3}{|c|}{ 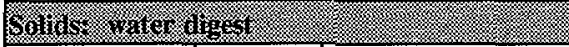 } & 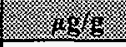 & 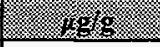 & $f=8$ \\
\hline $25-7755$ & $53: 1$ & Whole & 25.4 & 22 & 23.7 \\
\hline $33-7755$ & $54: 1$ & Partial & $<132$ & $<132$ & $<132$ \\
\hline
\end{tabular}


Table B2-65. Tank 241-T-105 Analytical Results: Arsenic (ICP).

\begin{tabular}{|c|c|c|c|c|c|}
\hline Simile & 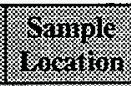 & $\begin{array}{l}\text { Sample } \\
\text { pom }\end{array}$ & 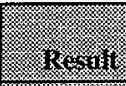 & 1.mplis: & (3) \\
\hline \multicolumn{3}{|c|}{ 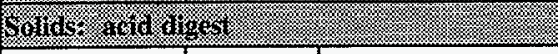 } & 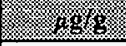 & 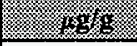 & 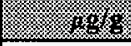 \\
\hline $25-8755$ & $53: 1$ & Whole & $<26.5$ & $<26.1$ & $<26.3$ \\
\hline $33-8755$ & \multirow[t]{3}{*}{$54: 1$} & Whole & $<26.8$ & $<26.9$ & $<26.85$ \\
\hline $41-8755$ & & Homogenization test & $<26.6$ & $<26.8$ & $<26.7$ \\
\hline $40-8755$ & & Homogenization test & $<26.9$ & $<26.9$ & $<26.9$ \\
\hline \multicolumn{3}{|l|}{ 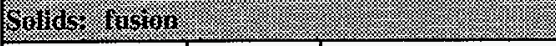 } & ( 19.8 & (3. & (n) \\
\hline $25-6775$ & $53: 1$ & Whole & $<14.8$ & $<14.8$ & $<14.8$ \\
\hline $33-6755$ & $54: 1$ & Whole & $<14.9$ & 26 & $<20.45$ \\
\hline \multicolumn{3}{|c|}{ 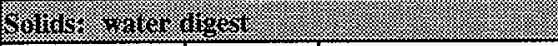 } & ) & r. & 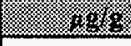 \\
\hline $25-7755$ & 53:1 & Whole & $<3.08$ & $<3.08$ & $<3.08$ \\
\hline $33-7755$ & $54: 1$ & Whole & $<27.7$ & $<27.7$ & $<27.7$ \\
\hline
\end{tabular}

Table B2-66. Tank 241-T-105 Analytical Results: Beryllium (ICP).

\begin{tabular}{|c|c|c|c|c|c|}
\hline 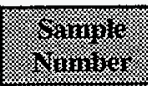 & 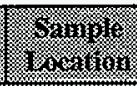 & 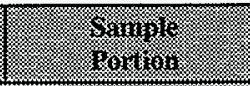 & n & 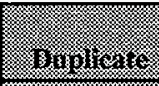 & 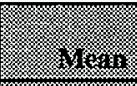 \\
\hline \multicolumn{3}{|c|}{ Soligs Jard ligess : } & 4.1969 & 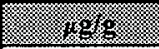 & 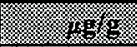 \\
\hline $25-8755$ & $53: 1$ & Whole & $<2.94$ & $<2.9$ & $<2.92$ \\
\hline $33-8755$ & \multirow[t]{3}{*}{$54: 1$} & Whole & $<2.97$ & $<2.99$ & $<2.98$ \\
\hline $41-8755$ & & Homogenization test & $<2.95$ & $<2.98$ & $<2.965$ \\
\hline $40-8755$ & & Homogenization test & $<2.99$ & $<2.99$ & $<2.99$ \\
\hline \multicolumn{2}{|c|}{ Sinids. invi, } & (1) & 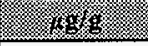 & 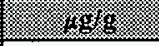 & 2.1968 \\
\hline $25-6775$ & $53: 1$ & Whole & $<1.48$ & $<1.48$ & $<1.48$ \\
\hline $33-6755$ & $54: 1$ & Whole & $<1.49$ & $<1.47$ & $<1.48$ \\
\hline \multicolumn{3}{|c|}{ 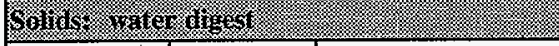 } & 4.6 & 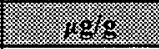 & 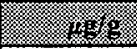 \\
\hline $25-7755$ & $53: 1$ & Whole & $<0.308$ & $<0.308$ & $<0.308$ \\
\hline $33-7755$ & $54: 1$ & Whole & $<3.08$ & $<3.08$ & $<3.08$ \\
\hline
\end{tabular}


Table B2-67. Tank 241-T-105 Analytical Results: Bismuth (ICP).

\begin{tabular}{|c|c|c|c|c|c|}
\hline Tamingie & 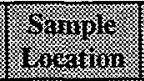 & 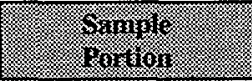 & riesum & 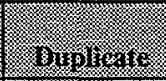 & Y Yean: \\
\hline \multicolumn{3}{|c|}{ 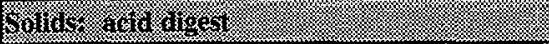 } & $\sqrt{185838}$ & 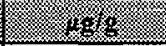 & 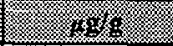 \\
\hline $25-8755$ & 53:1 & Whole & 1,190 & 1,320 & $1,255^{\mathrm{QC:a}}$ \\
\hline $33-8755$ & \multirow[t]{3}{*}{$54: 1$} & Whole & 1,360 & 1,440 & $1,400^{\mathrm{QC:}: \mathrm{a}}$ \\
\hline 41-8755 & & Homogenization test: & 1,300 & 1,470 & $1,385^{\mathrm{QC:}:}$ \\
\hline $40-8755$ & & Homogenization test & 1,300 & 1,280 & $1,290^{\text {eC:a }}$ \\
\hline \multicolumn{3}{|c|}{ 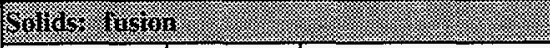 } & .498 & 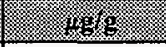 & 3. \\
\hline $25-6775$ & $53: 1$ & Whole & 999 & 1,110 & $1,054.5^{\mathrm{QC:c}}$ \\
\hline $33-6755$ & $54: 1$ & Whole & 1,190 & 1,570 & $1,380^{\text {eC:c,e }}$ \\
\hline \multicolumn{3}{|c|}{ 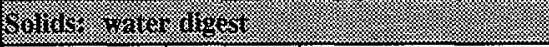 } & 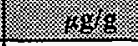 & $1,89$. & 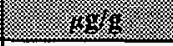 \\
\hline $25-7755$ & $53: 1$ & Whole & $<6.47$ & $<6.46$ & $<6.465^{\mathrm{QC:c}}$ \\
\hline $33-7755$ & $54: 1$ & Whole & $<44.1$ & $<44.1$ & $<44.1$ \\
\hline
\end{tabular}

Table B2-68. Tank 241-T-105 Analytical Results: Boron (ICP).

\begin{tabular}{|c|c|c|c|c|c|}
\hline 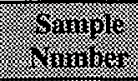 & singe & 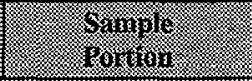 & Ris.sulm & 310010 are & yin \\
\hline \multicolumn{2}{|c|}{ Solins por anger } & 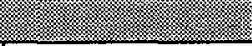 & 18.948 & 4.2898 & 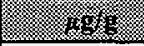 \\
\hline $25-8755$ & $53: 1$ & Whole & $<22.5$ & $<22.2$ & $<22.35^{\text {ec:b }}$ \\
\hline $33-8755$ & \multirow[t]{3}{*}{$54: 1$} & Whole & $<22.8$ & $<22.9$ & $<22.85^{\text {Qc:b }}$ \\
\hline $41-8755$ & & Homogenization test & $<22.6$ & $<22.8$ & $<22.7^{0 \mathrm{C:b}}$ \\
\hline $40-8755$ & & Homogenization test & $<23$ & $<23$ & $<23^{\alpha \mathrm{QC:b}}$ \\
\hline \multicolumn{3}{|c|}{ 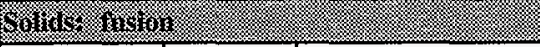 } & (1) & 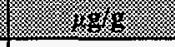 & 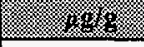 \\
\hline 25-6775 & $53: 1$ & Whole & $<4.92$ & $<4.94$ & $<4.93$ \\
\hline $33-6755$ & $54: 1$ & Whole & $<4.98$ & $<4.9$ & $<4.94$ \\
\hline \multicolumn{2}{|c|}{ 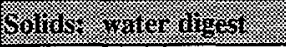 } & 8 & 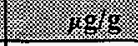 & 8.189 .8 & 8.896 \\
\hline $25-7755$ & $53: 1$ & Whole & 321 & 284 & $302.5^{\mathrm{QC:b}}$ \\
\hline 33-7755 & $54: 1$ & Whole & 320 & 415 & $367.5^{\text {QCie }}$ \\
\hline
\end{tabular}


Table B2-69. Tank 241-T-105 Analytical Results: Cadmium (ICP).

\begin{tabular}{|c|c|c|c|c|c|}
\hline Similoes & 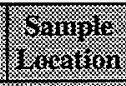 & (4) & Mesiul: & Iimiligate & VIorit \\
\hline \multicolumn{3}{|c|}{ 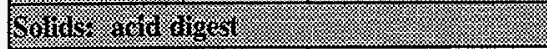 } & 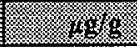 & 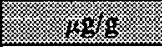 & 18948 \\
\hline $25-8755$ & $53: 1$ & Whole & 26.2 & 12.9 & $19.55^{\mathrm{OC:a,e}}$ \\
\hline $33-8755$ & \multirow[t]{3}{*}{$54: 1$} & Whole & 5.26 & $<3.98$ & $<4.62$ \\
\hline $41-8755$ & & Homogenization test & $<3.94$ & 15.9 & $<9.92$ \\
\hline $40-8755$ & & Homogenization test & 4.35 & 5.67 & $5.01^{\mathrm{CC}: \mathrm{A}, \mathrm{e}}$ \\
\hline \multicolumn{2}{|c|}{ Suldas 6 insing } & (2) & 10 & 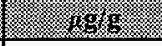 & 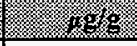 \\
\hline $25-6775$ & $53: 1$ & Whole & 18.3 & 20.1 & 19.2 \\
\hline $33-6755$ & $54: 1$ & Whole & 12.1 & 11 & 11.55 \\
\hline \multicolumn{3}{|c|}{ 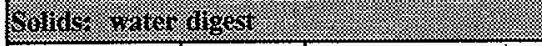 } & 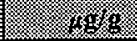 & 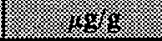 & 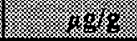 \\
\hline $25-7755$ & $53: 1$ & Whole & 4.1 & 1.52 & $2.81^{\mathrm{QC:e}}$ \\
\hline 33-7755 & $54: 1$ & Whole & $<4.1$ & $<4.11$ & $<4.105$ \\
\hline
\end{tabular}

Table B2-70. Tank 241-T-105 Aralytical Results: Calcium (ICP).

\begin{tabular}{|c|c|c|c|c|c|}
\hline 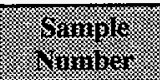 & 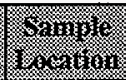 & 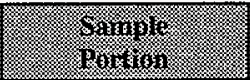 & 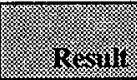 & 1) & Wrorn: \\
\hline \multicolumn{3}{|c|}{ 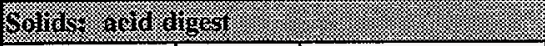 } & 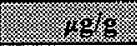 & $4.4 \mathrm{gg}$ & 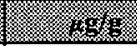 \\
\hline $25-8755$ & $53: 1$ & Whole & 1,410 & 1,590 & $1,500^{\mathrm{ec}: \mathrm{b}}$ \\
\hline $33-8755$ & \multirow[t]{3}{*}{$54: 1$} & Whole & 1,380 & 1,290 & $1,335^{\mathrm{Qc:b}}$ \\
\hline $41-8755$ & & Homogenization test & 1,320 & 1,340 & $1,330^{\propto \mathrm{C}: \mathrm{b}}$ \\
\hline $40-8755$ & & Homogenization test & 1,120 . & 1,170 & $1,145^{\mathrm{QC:b}}$ \\
\hline \multicolumn{2}{|c|}{ 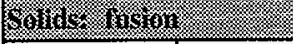 } & : & (2) & 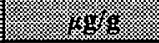 & 8.88 \\
\hline $25-6775$ & $53: 1$ & Whole & 7,170 & 2,930 & $5,050^{\mathrm{CC:e}}$ \\
\hline $33-6755$ & $54: 1$ & Whole & 1,580 & 3,000 & $2,290^{\mathrm{OC}: c, 0}$ \\
\hline \multicolumn{3}{|c|}{ 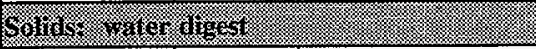 } & $\sqrt{3.828}$ & $\sqrt{86}$ & 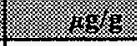 \\
\hline $25-7755$ & $53: 1$ & Whole & 108 & 126 & 117 \\
\hline $33-7755$ & $54: 1$ & Whole & 209 & 705 & $457^{\mathrm{QC}: 0}$ \\
\hline
\end{tabular}


Table B2-71. . Tank 241-T-105 Analytical Results: Cerium (ICP).

\begin{tabular}{|c|c|c|c|c|c|}
\hline Yimile & S Samingl & Oringie & Iresilis: & 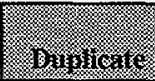 & (1) \\
\hline \multicolumn{3}{|c|}{ 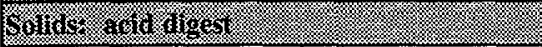 } & 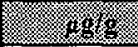 & 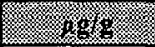 & 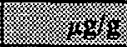 \\
\hline $25-8755$ & $53: 1$ & Whole & $<40.2$ & $<39.7$ & $<39.95$ \\
\hline $33-8755$ & \multirow[t]{3}{*}{$54: 1$} & Whole & $<40.6$ & $<40.8$ & $<40.7$ \\
\hline $41-8755$ & & Homogenization test & $<40.4$ & $<40.7$ & $<40.55$ \\
\hline $40-8755$ & & Homogenization test & $<40.9$ & $<40.9$ & $<40.9$ \\
\hline \multicolumn{3}{|c|}{ 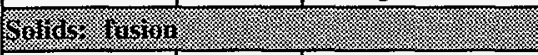 } & 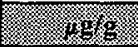 & $8.1 .6 \mathrm{c}$ & 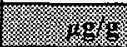 \\
\hline $25-6775$ & $53: 1$ & Whole & 122 & 102 & 112 \\
\hline $33-6755$ & $54: 1$ & Whole & 39.3 & 52.7 & $46^{\mathrm{ecc} c}$ \\
\hline \multicolumn{3}{|c|}{ 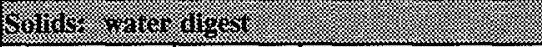 } & 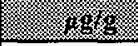 & . & $1=3.48$ \\
\hline $25-7755$ & $53: 1$ & Whole & $<6.99$ & $<6.97$ & $<6.98$ \\
\hline 33-7755 & $54: 1$ & Whole & $<42.1$ & $<42.1$ & $<42.1$ \\
\hline
\end{tabular}

Table B2-72. Tank 241-T-105 Analytical Results: Chromium (ICP).

\begin{tabular}{|c|c|c|c|c|c|}
\hline S3minte & (2020101 & $\begin{array}{l}\text { f } \\
\text { I }\end{array}$ & rim & 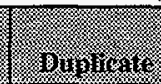 & 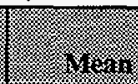 \\
\hline \multicolumn{3}{|c|}{ 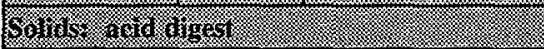 } & (1. & $4.1 .98 \mathrm{~g}$ & 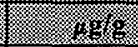 \\
\hline $25-8755$ & $53: 1$ & Whole & 679 & 774 & 726.5 \\
\hline $33-8755$ & \multirow[t]{3}{*}{$54: 1$} & Whole & 285 & 283 & 284 \\
\hline $41-8755$ & & Homogenization test & 277 & 267 & 272 \\
\hline $40-8755$ & & Homogenization test & 241 & 275 & 258 \\
\hline \multicolumn{3}{|c|}{ bulmis } & 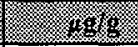 & 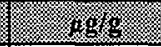 & . \\
\hline $25-6775$ & $53: 1$ & Whole & 619 & 606 & 612.5 \\
\hline $33-6755$ & $54: 1$ & Whole & 250 & 254 & 252 \\
\hline \multicolumn{3}{|c|}{ 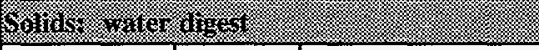 } & (1) & 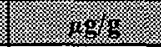 & I. \\
\hline $25-7755$ & $53: 1$ & Whole & 201 & 200 & $200.5^{\mathrm{CC:b}}$ \\
\hline $33-7755$ & $54: 1$ & Whole & 94.3 & 96.3 & 95.3 \\
\hline
\end{tabular}


Table B2-73. Tank 241-T-105 Analytical Results: Iron (ICP).

\begin{tabular}{|c|c|c|c|c|c|}
\hline 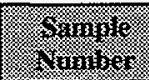 & Soringle: & Sompis & 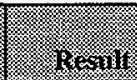 & Bimping: & M. \\
\hline \multicolumn{2}{|c|}{ 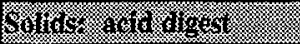 } & (1) & 4.998 & 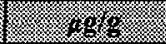 & 1.848 \\
\hline $25-8755$ & $53: 1$ & Whole & 63,100 & 28,000 & $45,550^{\text {eC:d,e }}$ \\
\hline $33-8755$ & \multirow[t]{3}{*}{$54: 1$} & Whole & 9,700 & 8,470 & $9,085^{\mathrm{CC}: d}$ \\
\hline $41-8755$ & & Homogenization test & 8,020 & 26,400 & $17,210^{\text {QC:e }}$ \\
\hline $40-8755$ & & Homogenization test & 12,700 & 11,400 & 12,050 \\
\hline \multicolumn{2}{|c|}{ 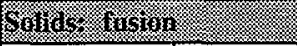 } & স) & $\sqrt{1,869}$ & (2) & 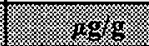 \\
\hline $25-6775$ & $53: 1$ & Whole & 33,700 & 47,500 & $40,600^{\mathrm{eC:d,e}}$ \\
\hline $33-6755$ & $54: 1$ & Whole & 25,000 & 26,000 & 25,500 \\
\hline \multicolumn{3}{|c|}{ 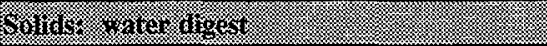 } & 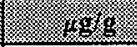 & 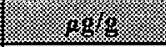 & 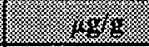 \\
\hline $25-7755$ & $53: 1$ & Whole & 2.01 & 3.28 & $2.645^{\mathrm{QC:c}}$ \\
\hline $33-7755$ & $54: 1$ & Whole & 16.8 & 19.6 & 18.2 \\
\hline
\end{tabular}

Table B2-74. Tank 241-T-105 Analytical Results: Lanthanum (ICP).

\begin{tabular}{|c|c|c|c|c|c|}
\hline Ving & 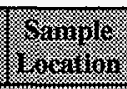 & (3) & (2).8.11: & (3) & s) \\
\hline \multicolumn{3}{|c|}{ 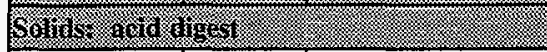 } & 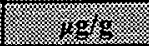 & f $18 \mathrm{gs}$ & 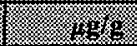 \\
\hline $25-8755$ & $53: 1$ & Whole & 16.8 & 31.9 & $24.35^{\mathrm{QC:0}}$ \\
\hline $33-8755$ & \multirow[t]{3}{*}{$54: 1$} & Whole & $<15.9$ & $<15.9$ & $<15.9$ \\
\hline $41-8755$ & & Homogenization test & $<15.7$ & $<15.9$ & $<15.8$ \\
\hline $40-8755$ & & Homogenization test & $<16$ & $<16$ & $<16$ \\
\hline \multicolumn{3}{|c|}{ 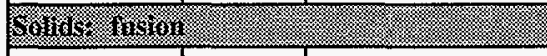 } & . & 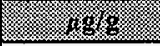 & 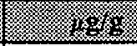 \\
\hline $25-6775$ & $53: 1$ & Whole & $<8.37$ & $<8.4$ & $<8.385$ \\
\hline $33-6755$ & $54: 1$ & Whole & $<8.47$ & $<8.33$ & $<8.4$ \\
\hline \multicolumn{3}{|c|}{ 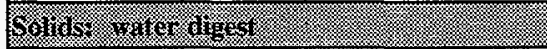 } & 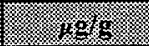 & 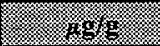 & 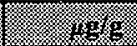 \\
\hline $25-7755$ & $53: 1$ & Whole & $<1.75$ & $<1.74$ & $<1.745$ \\
\hline $33-7755$ & $54: 1$ & Whole & $<16.4$ & $<16.4$ & $<16.4$ \\
\hline
\end{tabular}


Table B2-75. Tank 241-T-105 Analytical Results: Lead (ICP).

\begin{tabular}{|c|c|c|c|c|c|}
\hline Sominio & 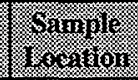 & Sample & risis & Duplisive & 12. \\
\hline \multicolumn{3}{|c|}{ 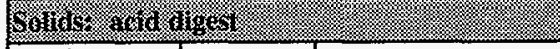 } & 1.868 & 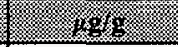 & 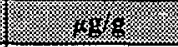 \\
\hline $25-8755$ & $53: 1$ & Whole & 859 & 739 & 799 \\
\hline $33-8755$ & \multirow[t]{3}{*}{$54: 1$} & Whole & 302 & 236 & $269^{\mathrm{QC:e}}$ \\
\hline $41-8755$ & & Homogenization test & 196 & 396 & $296^{\mathrm{QC}: 0}$ \\
\hline $40-8755$ & & Homogenization test & 320 & 211 & $265.5^{\mathrm{QC:e}}$ \\
\hline \multicolumn{3}{|c|}{ 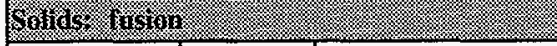 } & 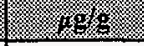 & 8 & 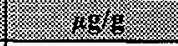 \\
\hline $25-6775$ & $53: 1$ & Whole & 630 & 578 & 604 \\
\hline $33-6755$ & $54: 1$ & Whole & 326 & 277 & 301.5 \\
\hline \multicolumn{3}{|c|}{ 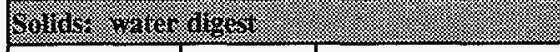 } & 2.8 .8 .86 & 8.868 & 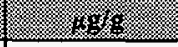 \\
\hline $25-7755$ & $53: 1$ & Whole & $<6.37$ & 10 & $<8.185$ \\
\hline $33-7755$ & $54: 1$ & Whole & $<39$ & 48.3 & $<43.65$ \\
\hline
\end{tabular}

Table B2-76. Tank 241-T-105 Analytical Results: Lithium (ICP).

\begin{tabular}{|c|c|c|c|c|c|}
\hline S & 7rigile & 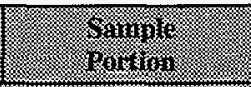 & Ry & bigition & - \\
\hline \multicolumn{3}{|c|}{ Solith. alid aggests } & 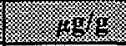 & - 145 & 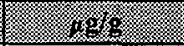 \\
\hline $25-8755$ & $53: 1$ & Whole & 4.87 & $<3.87$ & $<4.37$ \\
\hline $33-8755$ & \multirow[t]{3}{*}{$54: 1$} & Whole & $<3.96$ & 4.18 & $<4.07$ \\
\hline $41-8755$ & & Homogenization test & $<3.94$ & 5.32 & $<4.63$ \\
\hline $40-8755$ & & Homogenization test & $<3.99$ & $<3.99$ & $<3.99$ \\
\hline \multicolumn{2}{|c|}{ 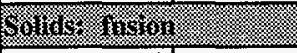 } & & 18.8 & 3.38 & 8.898 \\
\hline $25-6775$ & $53: 1$ & Whole & 4.16 & 4.32 & 4.24 \\
\hline $33-6755$ & $54: 1$ & Whole & 2.37 & 3.51 & $2.94^{\mathrm{eC}: 0}$ \\
\hline \multicolumn{3}{|c|}{ 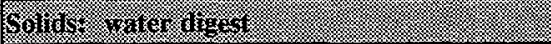 } & 8 & 3.18 & . \\
\hline $25-7755$ & $53: 1$ & Whole & $<0.411$ & $<0.41$ & $<0.4105$ \\
\hline $33-7755$ & $54: 1$ & Whole & $<4.1$ & $<4.11$ & $<4.105$ \\
\hline
\end{tabular}


Table B2-77. Tank 241-T-105 Analytical Results: Magnesium (ICP).

\begin{tabular}{|c|c|c|c|c|c|}
\hline Sampile & Soringle & Strmile & Restil & Wingilowe & 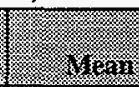 \\
\hline \multicolumn{3}{|c|}{ 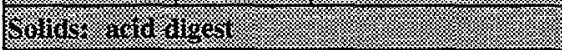 } & 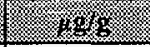 & 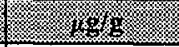 & f \\
\hline $25-8755$ & $53: 1$ & Whole & 935 & 1,120 & $1,027.5$ \\
\hline $33-8755$ & \multirow[t]{3}{*}{$54: 1$} & Whole & 1,070 & 1,130 & 1,100 \\
\hline $41-8755$ & & Homogenization test & 1,110 & 1,060 & $1,085^{\mathrm{QC}: \mathrm{b}}$ \\
\hline $40-8755$ & & Homogenization test & 959 & 1,040 & 999.5 \\
\hline \multicolumn{2}{|c|}{ Sintidsi rosinu } & 4 & 1.368 & 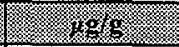 & (1) \\
\hline $25-6775$ & $53: 1$ & Whole & 1,220 & 1,280 & 1,250 \\
\hline $33-6755$ & $54: 1$ & Whole & 997 & 918 & 957.5 \\
\hline \multicolumn{3}{|c|}{ 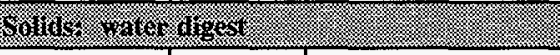 } & 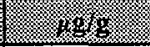 & 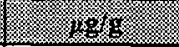 & 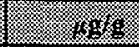 \\
\hline $25-7755$ & $53: 1$ & Whole & 6.23 & 6.56 & 6.395 \\
\hline $33-7755$ & $54: 1$ & Whole & 19.8 & 25 & $22.4^{\text {QC:e }}$ \\
\hline
\end{tabular}

Table B2-78. Tank 241-T-105 Analytical Results: Manganese (ICP).

\begin{tabular}{|c|c|c|c|c|c|}
\hline Sample & 5aivi!le & 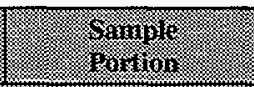 & . in: & 3iviticive & 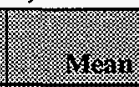 \\
\hline \multicolumn{2}{|c|}{ 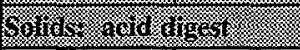 } & " & 4.4846 & $3 ., 1.68$ & 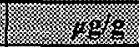 \\
\hline $25-8755$ & $53: 1$ & Whole & 17,900 & 21,800 & $19,850^{\mathrm{QC:d}}$ \\
\hline $33-8755$ & \multirow[t]{3}{*}{$54: 1$} & Whole & 3,400 & 3,250 & 3,325 \\
\hline $41-8755$ & & Homogenization test & 3,030 & 3,070 & 3,050 \\
\hline $40-8755$ & & Homogenization test & 2,970 & 2,830 & 2,900 \\
\hline \multicolumn{2}{|l|}{ 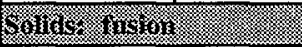 } & 8. & 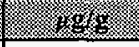 & 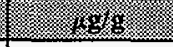 & 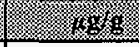 \\
\hline $25-6775$ & $53: 1$ & Whole & 18,000 & 17,800 & $17,900^{\alpha<: d}$ \\
\hline $33-6755$ & $54: 1$ & Whole & 3,190 & 2,420 & $2,805^{\mathrm{QC}: \mathrm{d}, \mathrm{e}}$ \\
\hline \multicolumn{3}{|c|}{ 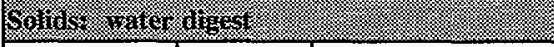 } & 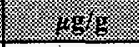 & (1) & 4.98 \\
\hline 25-7755 & $53: 1$ & Whole & 0.783 & 0.936 & 0.8595 \\
\hline 33-7755 & $54: 1$ & Whole & $<3.08$ & $<3.08$ & $<3.08$ \\
\hline
\end{tabular}


Table B2-79. Tank 241-T-105 Analytical Results: Molybdenum (ICP).

\begin{tabular}{|c|c|c|c|c|c|}
\hline Vinuples & Socinion & 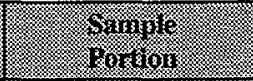 & iresillis & Bupiticate & in \\
\hline \multicolumn{2}{|c|}{ 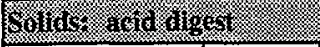 } & 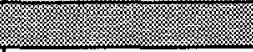 & 18.8 & 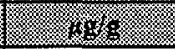 & 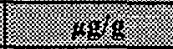 \\
\hline $25-8755$ & $53: 1$ & Whole & 38.1 & 43.3 & 40.7 \\
\hline $33-8755$ & \multirow[t]{3}{*}{$54: 1$} & Whole & 28.3 & 27.5 & 27.9 \\
\hline $41-8755$ & & Homogenization test & 20.4 & 23 & 21.7 \\
\hline $40-8755$ & & Homogenization test & 20.6 & 24.8 & 22.7 \\
\hline \multicolumn{3}{|l|}{ 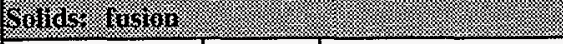 } & 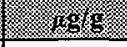 & (1) & 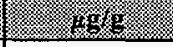 \\
\hline $25-6775$ & $53: 1$ & Whole & 37.2 & 41.8 & 39.5 \\
\hline $33-6755$ & $54: 1$ & Whole & 23.7 & 23.9 & 23.8 \\
\hline \multicolumn{3}{|c|}{ for mis } & 1 & (1) 18.83 & 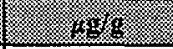 \\
\hline $25-7755$ & $53: 1$ & Whole & 47.5 & 47.9 & 47.7 \\
\hline $33-7755$ & $54: 1$ & Whole & 21.3 & 22.1 & 21.7 \\
\hline
\end{tabular}

Table B2-80. Tank 241-T-105 Analytical Results: Neodymium (ICP).

\begin{tabular}{|c|c|c|c|c|c|}
\hline 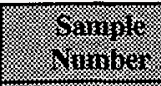 & 25ingic & 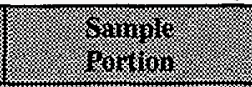 & iserifi: & ninging & 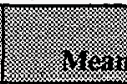 \\
\hline \multicolumn{3}{|c|}{ 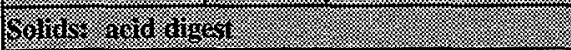 } & 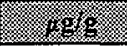 & 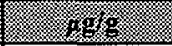 & 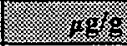 \\
\hline $25-8755$ & $53: 1$ & Whole & 159 & 145 & 152 \\
\hline $33-8755$ & \multirow[t]{3}{*}{$54: 1$} & Whole & $<59.5$ & $<59.7$ & $<59.6$ \\
\hline $41-8755$ & & Homogenization test & $<59.1$ & 73.4 & $<66.25$ \\
\hline $40-8755$ & & Homogenization test & $<59.9$ & $<59.9$ & $<59.9$ \\
\hline \multicolumn{3}{|c|}{ 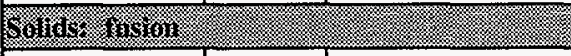 } & 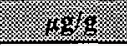 & 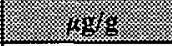 & 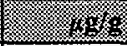 \\
\hline $25-6775$ & $53: 1$ & Whole & 96.1 & 124. & $110.05^{\mathrm{eCsc}}$ \\
\hline $33-6755$ & $54: 1$ & Whole & $<40.8$ & 40.6 & $<40.7$ \\
\hline \multicolumn{3}{|c|}{ 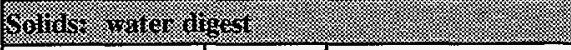 } & 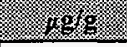 & $8.83 \%$ & 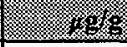 \\
\hline $25-7755$ & $53: 1$ & Whole & $<8.43$ & $<8.41$ & $<8.42$ \\
\hline $33-7755$ & $54: 1$ & Whole & $<61.5$ & $<61.6$ & $<61.55$ \\
\hline
\end{tabular}


Table B2-81. Tank 241-T-105 Analytical Results: Nickel (ICP).

\begin{tabular}{|c|c|c|c|c|c|}
\hline Simule & I Sampic & 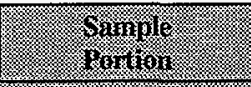 & inesil & Ouplicate & $2.8 \mathrm{can}$ \\
\hline \multicolumn{3}{|c|}{ 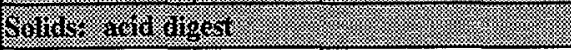 } & 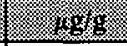 & 4.4 .969 & 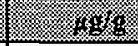 \\
\hline $25-8755$ & $53: 1$ & Whole & 91.1 & 102 & 96.55 \\
\hline $33-8755$ & \multirow[t]{3}{*}{$54: 1$} & Whole & 64.5 & 67.6 & 66.05 \\
\hline $41-8755$ & & Homogenization test & 63.7 & 71.8 & 67.75 \\
\hline $40-8755$ & & Homogenization test & 56.7 & 56.9 & 56.8 \\
\hline \multicolumn{3}{|c|}{ 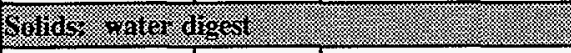 } & 1.8945 & 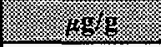 & $4.8 \mathrm{~g} \cdot 1$. \\
\hline $25-7755$ & $53: 1$ & Whole & 13.8 & 14 & 13.9 \\
\hline 33-7755 & $54: 1$ & Whole & 11.5 & $<11.3$ & $<11.4$ \\
\hline
\end{tabular}

Table B2-82. Tank 241-T-105 Analytical Results: Phosphorus (ICP).

\begin{tabular}{|c|c|c|c|c|c|}
\hline Virinjle: & 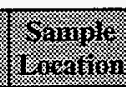 & 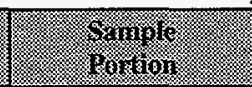 & kiengus & Divilizats & 13 \\
\hline \multicolumn{2}{|c|}{ 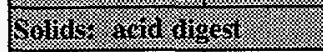 } & 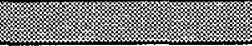 & 1.98 & $4=898$ & (1) \\
\hline $25-8755$ & $53: 1$ & Whole & 1,710 & 1,900 & 1,805 \\
\hline $33-8755$ & \multirow[t]{3}{*}{$54: 1$} & Whole & 1,210 & 1,150 & 1,180 \\
\hline $41-8755$ & & Fomogenization test & 1,140 & 1,130 & 1,135 \\
\hline $40-8755$ & & Homogenization test & 976 & 1,180 & $1,078^{\mathrm{QC:d}}$ \\
\hline \multicolumn{3}{|l|}{ Sabidis: minisin } & 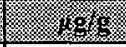 & 18 & $1=8,850$ \\
\hline $25-6775$ & $53: 1$ & Whole & 1,910 & 2,000 & 1,955 \\
\hline $33-6755$ & $54: 1$ & Whole & 1,160 & 1,060 & 1,110 \\
\hline \multicolumn{3}{|c|}{ 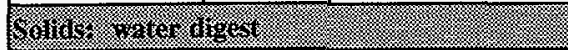 } & 1) & 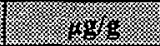 & 样 \\
\hline $25-7755$ & $53: 1$ & Whole & 911 & 871 & 891 \\
\hline $33-7755$ & $54: 1$ & Whole & 314 & 523 & $418.5^{\mathrm{QC:d,e}}$ \\
\hline
\end{tabular}


Table B2-83. Tank 241-T-105 Analytical Results: Potassium (ICP).

\begin{tabular}{|c|c|c|c|c|c|}
\hline 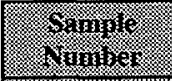 & S Shangle & ramile & resinil & ininglivat: & Hear \\
\hline \multicolumn{3}{|c|}{ 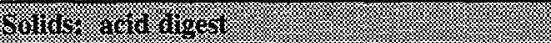 } & 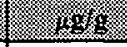 & 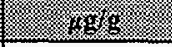 & (2) \\
\hline $25-8755$ & $53: 1$ & Whole & 346 & 449 & $397.5^{\mathrm{QC:a,e}}$ \\
\hline $33-8755$ & \multirow[t]{3}{*}{$54: 1$} & Whole & 234 & 191 & 212.5 \\
\hline $41-8755$ & & Homogenization test & 210 & 155 & $182.5^{Q \mathrm{C}: a, e}$ \\
\hline $40-8755$ & & Homogenization test & 231 & 276 & 253.5 \\
\hline \multicolumn{3}{|c|}{ 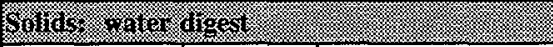 } & 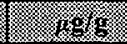 & 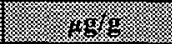 & 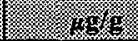 \\
\hline $25-7755$ & $53: 1$ & Whole & 369 & 377 & 373 \\
\hline $33-7755$ & $54: 1$ & Whole & 237 & 121 & $179^{\alpha<: 0}$ \\
\hline
\end{tabular}

Table B2-84. Tank 241-T-105 Analytical Results: Samarium (ICP).

\begin{tabular}{|c|c|c|c|c|c|}
\hline 8. ringes & 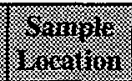 & 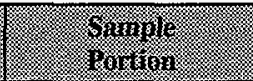 & ticsin: & 3 3ivilinat & (1) 6413 \\
\hline 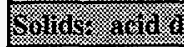 & gest & (1) & 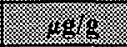 & : & 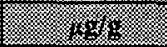 \\
\hline $25-8755$ & $53: 1$ & Whole & $<43.1$ & $<42.6$ & $<42.85$ \\
\hline $33-8755$ & \multirow[t]{3}{*}{$54: 1$} & Whole & 57.6 & 55.1 & $56.35^{\mathrm{QC:a}}$ \\
\hline $41-8755$ & & Homogenization test & 68.1 & 106 & $87.05^{\mathrm{QC} ; \mathrm{a}, \mathrm{c}}$ \\
\hline $40-8755$ & & Homogenization test & $<43.9$ & 63.8 & $<53.85^{\mathrm{eC:a,c}}$ \\
\hline \multicolumn{2}{|l|}{ 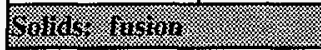 } & & 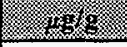 & 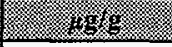 & 8 \\
\hline $25-6775$ & $53: 1$ & Whole & 94.8 & 78.8 & 86.8 \\
\hline $33-6755$ & $54: 1$ & Whole & 61.9 & 46.1 & $54^{\mathrm{QC:O}}$ \\
\hline \multicolumn{3}{|c|}{ 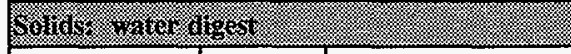 } & 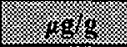 & 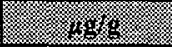 & .189 \\
\hline $25-7755$ & $53: 1$ & Whole & $<9.66$ & $<9.64$ & $<9.65$ \\
\hline $33-7755$ & $54: 1$ & Whole & $<45.1$ & $<45.2$ & $<45.15$ \\
\hline
\end{tabular}


Table B2-85. Tank 241-T-105 Analytical Results: Selenium (ICP).

\begin{tabular}{|c|c|c|c|c|c|}
\hline Yininger & S Saringe & 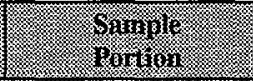 & nisin: & Bopligat e & 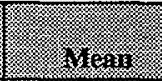 \\
\hline \multicolumn{3}{|c|}{ 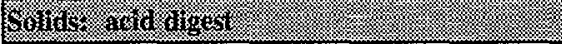 } & $=1.96$ & $2.89 \mathrm{gg}$ & $(48,8=$ \\
\hline $25-8755$ & $53: 1$ & Whole & $<61.8$ & $<60.9$ & $<61.35^{\mathrm{QC:a,c}}$ \\
\hline $33-8755$ & \multirow[t]{3}{*}{$54: 1$} & Whole & $<62.4$ & $<62.7$ & $<62.55^{\text {QC:a, }}$ \\
\hline $41-8755$ & & Homogenization test & $<62$ & $<62.6$ & $<62.3^{\mathrm{QCOA}, \mathrm{c}}$ \\
\hline $40-8755$ & & Homogenization test & $<62.9$ & $<62.9$ & $<62.9^{\text {eC:a,ce }}$ \\
\hline \multicolumn{2}{|c|}{ Soung } & 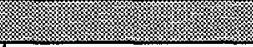 & 1.989 & 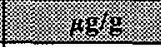 & 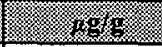 \\
\hline $25-6775$ & $53: 1$ & Whole & $<42.8$ & $<43$ & $<42.9^{\text {ec:c }}$ \\
\hline $33-6755$ & $54: 1$ & Whole & $<43.3$ & $<42.6$ & $<42.95$ \\
\hline \multicolumn{3}{|c|}{ 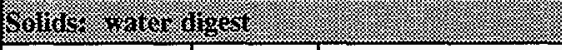 } & 2.28 & 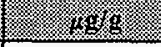 & (3) \\
\hline $25-7755$ & $53: 1$ & Whole & $<8.94$ & $<8.92$ & $<8.93^{\mathrm{OC}: \mathrm{c}}$ \\
\hline 33-7755 & $54: 1$ & Whole & $<64.6$ & 74.7 & $<69.65^{\mathrm{QC}: \mathrm{a}, \mathrm{c}}$ \\
\hline
\end{tabular}

Table B2-86. Tank 241-T-105 Analytical Results: Silicon (ICP).

\begin{tabular}{|c|c|c|c|c|c|}
\hline Samiges & 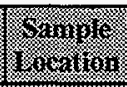 & Simitio & nesion & stringinger. & $\sqrt{18}$ \\
\hline \multicolumn{2}{|c|}{ 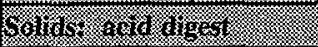 } & 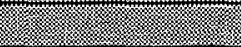 & 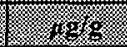 & . & 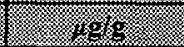 \\
\hline $25-8755$ & $53: 1$ & Whole & 2,380 & 2,120 & $2,250^{\mathrm{eC}: \mathrm{b}}$ \\
\hline $33-8755$ & \multirow[t]{3}{*}{$54: 1$} & Whole & 90 & 54.9 & $72.45^{\mathrm{QC}: b, \mathrm{e}}$ \\
\hline $41-8755$ & & Homogenization test & 243 & 332 & $287.5^{\mathrm{QC:b,o}}$ \\
\hline $40-8755$ & & Homogenization test & 216 & 244 & $230^{e C: b}$ \\
\hline \multicolumn{2}{|l|}{ 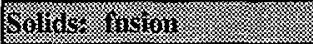 } & & 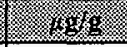 & (2) & r \\
\hline $25-6775$ & 53:1 & Whole & 6,420 & 9,110 & $7,765^{\text {QC:e }}$ \\
\hline $33-6755$ & $54: 1$ & Whole & 6,640 & 5,760 & 6,200 \\
\hline \multicolumn{2}{|c|}{ 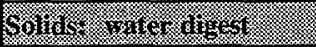 } & & (3. & 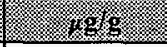 & (3) \\
\hline 25-7755 & $53: 1$ & Whole & 514 & 466 & $490^{\circ \mathrm{COd}}$ \\
\hline $33-7755$ & $54: 1$ & Whole & 946 & 1,060 & $1,003^{\mathrm{oC}: \mathrm{b}, \mathrm{d}}$ \\
\hline
\end{tabular}


Table B2-87. Tank 241-T-105 Analytical Results: Silver (ICP).

\begin{tabular}{|c|c|c|c|c|c|}
\hline 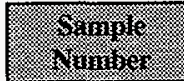 & Saminele & 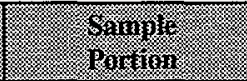 & Inesur: & 3uminionte. & 118. \\
\hline forims- is & 46 & (1) & 10.88 & 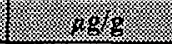 & 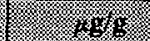 \\
\hline $25-8755$ & $53: 1$ & Whole & 9.96 & 16.9 & $13.43^{\mathrm{QC:}: \mathrm{ace}}$ \\
\hline $33-8755$ & \multirow[t]{3}{*}{$54: 1$} & Whole & 20.1 & 19.5 & $19.8^{\mathrm{QC}: \mathrm{A}, \mathrm{c}}$ \\
\hline $41-8755$ & & Homogenization test & 21.6 & 16.2 & $18.9^{\mathrm{QC}: \mathrm{a}, \mathrm{C}}$ \\
\hline $40-8755$ & & Homogenization test & 17.8 & 20.2 & $19^{\mathrm{QC:a}}$ \\
\hline \multicolumn{3}{|l|}{ 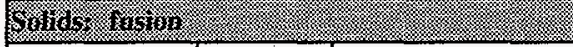 } & 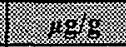 & $1,0.48 .8$ & 19.8. \\
\hline $25-6775$ & $53: 1$ & Whole & 66.4 & 72.2 & 69.3 \\
\hline $33-6755$ & $54: 1$ & Whole & 25.9 & 20.3 & $23.1^{\mathrm{OC:e}}$ \\
\hline \multicolumn{3}{|c|}{ 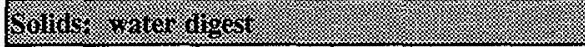 } & 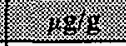 & 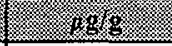 & 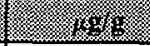 \\
\hline $25-7755$ & $53: 1$ & Whole & 4.89 & 5.43 & 5.16 \\
\hline 33-7755 & $54: 1$ & Whole & $<6.15$ & $<6.16$ & $<6.155^{\mathrm{QC}: \mathrm{c}}$ \\
\hline
\end{tabular}

Table B2-88. Tank 241-T-105 Analytical Results: Sodium (ICP).

\begin{tabular}{|c|c|c|c|c|c|}
\hline 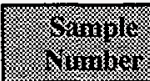 & 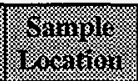 & (3) & res. & 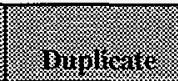 & 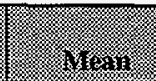 \\
\hline \multicolumn{3}{|c|}{ 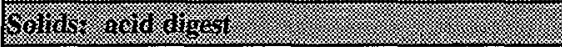 } & 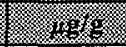 & 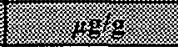 & (1) \\
\hline $25-8755$ & $53: 1$ & Whole & 63,300 & 73,900 & $68,600^{\alpha c: b, d}$ \\
\hline $33-8755$ & \multirow[t]{3}{*}{$54: 1$} & Whole & 44,900 & 43,200 & $44,050^{\varrho \mathrm{C}: \mathrm{b}, \mathrm{d}}$ \\
\hline $41-8755$ & & Homogenization test & 43,200 & 41,700 & $42,450^{\propto C: b, d}$ \\
\hline $40-8755$ & & Homogenization test & 38,900 & 41,400 & $40,150^{\mathrm{QC}: b, \mathrm{~d}}$ \\
\hline \multicolumn{2}{|c|}{ 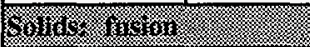 } & 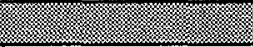 & 1.889 & 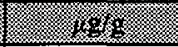 & 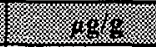 \\
\hline $25-6775$ & $53: 1$ & Whole & 61,400 & 62,800 & $62,100^{\mathrm{Qc}: \mathrm{d}}$ \\
\hline $33-6755$ & $54: 1$ & Whole & 40,800 & 31,800 & $36,300^{\mathrm{QC:d,o}}$ \\
\hline \multicolumn{3}{|c|}{ 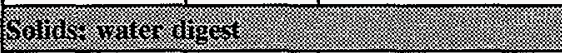 } & 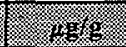 & (1) & f) \\
\hline $25-7755$ & $53: 1$ & Whole & 60,300 & 60,800 & $60,550^{\mathrm{eC}: \mathrm{d}}$ \\
\hline $33-7755$ & $54: 1$ & Whole & 37,500 & 39,200 & $38,350^{\mathrm{QC}: c}$ \\
\hline
\end{tabular}


Table B2-89. Tank 241-T-105 Analytical Results: Strontium (ICP).

\begin{tabular}{|c|c|c|c|c|c|}
\hline Sumines: & S4ringle & 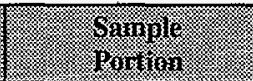 & ilesing & Gupingate & rivern \\
\hline \multicolumn{3}{|c|}{ 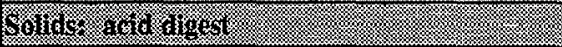 } & $\sqrt{10968}$ & 1. & $8 / 0 \mathrm{~g}$ \\
\hline $25-8755$ & $53: 1$ & Whole & 121 & 136 & 128.5 \\
\hline $33-8755$ & \multirow[t]{3}{*}{$54: 1$} & Whole & 163 & 170 & 166.5 \\
\hline $41-8755$ & & Homogenization test & 166 & 163 & 164.5 \\
\hline $40-8755$ & & Homogenization test & 152 & 159 & 155.5 \\
\hline \multicolumn{2}{|l|}{ 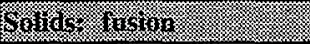 } & 1. & 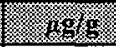 & 18.89 & 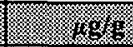 \\
\hline $25-6775$ & $53: 1$ & Whole & 126 & 133 & 129.5 \\
\hline $33-6755$ & $54: 1$ & Whole & 161 & 145 & 153 \\
\hline \multicolumn{2}{|c|}{ 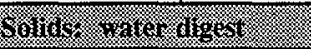 } & & 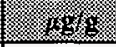 & 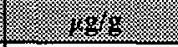 & 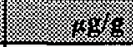 \\
\hline $25-7755$ & $53: 1$ & Whole & 0.917 & 1.04 & 0.9785 \\
\hline $33-7755$ & $54: 1$ & Whole & $<3.08$ & $<3.08$ & $<3.08$ \\
\hline
\end{tabular}

Table B2-90. Tank 241-T-105 Analytical Results: Sulfur (ICP).

\begin{tabular}{|c|c|c|c|c|c|}
\hline 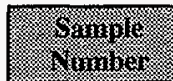 & 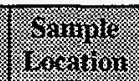 & $\begin{array}{l}\text { Timinis } \\
\text { nortions }\end{array}$ & 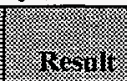 & Buploris & (2) \\
\hline \multicolumn{3}{|c|}{ 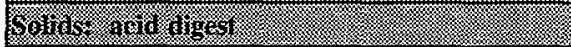 } & 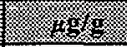 & 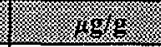 & 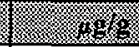 \\
\hline $25-8755$ & $53: 1$ & Whole & 2,990 & 3,630 & $3,310^{\mathrm{ec}: \mathrm{b}}$ \\
\hline $33-8755$ & \multirow[t]{3}{*}{$54: 1$} & Whole & 1,940 & 1,860 & 1,900 \\
\hline $41-8755$ & & Homogenization test & 1,970 . & 1,860 & $1,915^{\text {QC:b }}$ \\
\hline $40-8755$ & & Homogenization test & 1,620 & 1,830 & $1,725^{\mathrm{QC}: \mathrm{b}}$ \\
\hline \multicolumn{3}{|l|}{ 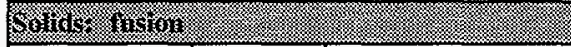 } & 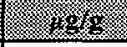 & $z_{2}$ & 18 \\
\hline $25-6775$ & $53: 1$ & Whole & 3,370 & 3,570 & 3,470 \\
\hline $33-6755$ & $54: 1$ & Whole & 1,830 & 1,710 & 1,770 \\
\hline \multicolumn{3}{|c|}{ 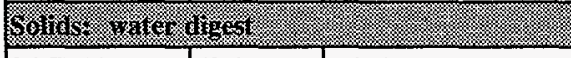 } & 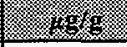 & I) & 1 \\
\hline $25-7755$ & $53: 1$ & Whole & 3,450 & 3,460 & $3,455^{\mathrm{QC}: \mathrm{d}}$ \\
\hline 33-7755 & $54: 1$ & Whole & 1,950 & 2,160 & 2,055 \\
\hline
\end{tabular}


Table B2-91. Tank 241-T-105 Analytical Results: Thallium (ICP).

\begin{tabular}{|c|c|c|c|c|c|}
\hline 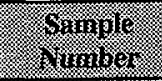 & Sumporion & $\begin{array}{l}\text { Samine } \\
\text { 9orron }\end{array}$ & resing: & 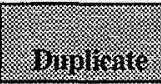 & Wrean \\
\hline \multicolumn{3}{|c|}{ 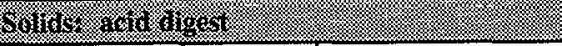 } & 8.18389 & - 189 & 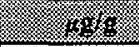 \\
\hline $25-8755$ & 53:1 & Whole & $<79.4$ & $<78.3$ & $<78.85^{\text {QC: }}$ \\
\hline $33-8755$ & \multirow[t]{3}{*}{$54: 1$} & Whole & 97.8 & 104 & $100.9^{\text {QC:a,c }}$ \\
\hline $41-8755$ & & Homogenization test & $<79.7$ & $<80.4$ & $<80.05^{\mathrm{QC}: \mathrm{z}}$ \\
\hline $40-8755$ & & Homogenization test & 91.9 & $<80.8$ & $<86.35$ \\
\hline \multicolumn{3}{|c|}{ 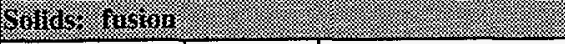 } & 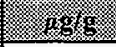 & (3. 18.5 & 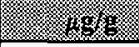 \\
\hline $25-6775$ & $53: 1$ & Whole & $<80.7$ & $<81$ & $<80.85$ \\
\hline $33-6755$ & $54: 1$ & Whole & $<81.7$ & $<80.4$ & $<81.05$ \\
\hline \multicolumn{3}{|c|}{ 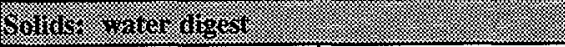 } & 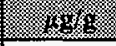 & 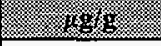 & 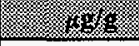 \\
\hline $25-7755$ & $53: 1$ & Whole & $<16.9$ & $<16.8$ & $<16.85$ \\
\hline $33-7755$ & $54: 1$ & Whole & $<83.1$ & $<83.2$ & $<83.15$ \\
\hline
\end{tabular}

Table B2-92. Tank 241-T-105 Analytical Results: Titanium (ICP).

\begin{tabular}{|c|c|c|c|c|c|}
\hline 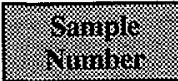 & Solminle & 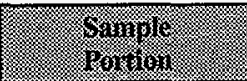 & isestis & Prinicicis & 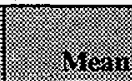 \\
\hline \multicolumn{3}{|c|}{ 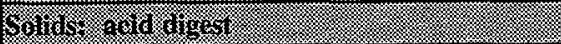 } & 4 & 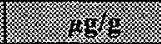 & 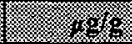 \\
\hline $25-8755$ & $53: 1$ & Whole & 57 & 79 & $68^{\mathrm{QCic}}$ \\
\hline $33-8755$ & \multirow[t]{3}{*}{$54: 1$} & Whole & 47.7 & 51.6 & 49.65 \\
\hline $41-8755$ & & Homogenization test & 48.7 & 47.2 & 47.95 \\
\hline $40-8755$ & & Homogenization test & 43.6 & 46 & 44.8 \\
\hline \multicolumn{3}{|l|}{ Somis: insingr: } & $=1868$ & 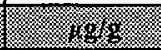 & 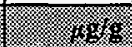 \\
\hline $25-6775$ & $53: 1$ & Whole & 257 & 486 & $371.5^{\mathrm{QC:0}}$ \\
\hline $33-6755$ & $54: 1$ & Whole & 82.3 & 85.6 & 83.95 \\
\hline \multicolumn{3}{|c|}{ 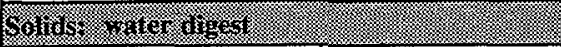 } & 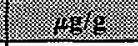 & 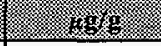 & 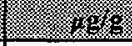 \\
\hline $25-7755$ & $53: 1$ & Whole & $<0.308$ & $<0.308$ & $<0.308$ \\
\hline 33-7755 & $54: 1$ & Whole & $<3.08$ & $<3.08$ & $<3.08$ \\
\hline
\end{tabular}


Table B2-93. Tank 241-T-105 Analytical Results: Zirconium (ICP).

\begin{tabular}{|c|c|c|c|c|c|}
\hline STrunje & 5ovarile & $\begin{array}{l}\text { Shamile } \\
\text { Temition }\end{array}$ & Mesills & guantion & Mras \\
\hline \multicolumn{3}{|c|}{ 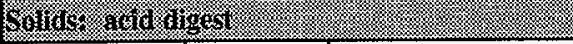 } & .1898 & 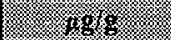 & 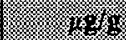 \\
\hline $25-8755$ & $53: 1$ & Whole & 89.9 & 87.9 & 88.9 \\
\hline $33-8755$ & \multirow[t]{3}{*}{$54: 1$} & Whole & $<14.4$ & 11.1 & $<12.75$ \\
\hline $41-8755$ & & Homogenization test & 17.1 & 78.4 & $47.75^{\mathrm{QC}: e}$ \\
\hline $40-8755$ & & Homogenization test & 73.5 & 74 & 73.75 \\
\hline 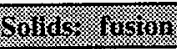 & $\sqrt{3}$ & (2) & 1,892 & (1) & (1) 10.5 \\
\hline $25-6775$ & $53: 1$ & Whole & 176 & 115 & $145.5^{\mathrm{OC: \textrm {c }}}$ \\
\hline $33-6755$ & $54: 1$ & Whole & 99.8 & 83.5 & 91.65 . \\
\hline 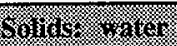 & (1) & & $8.18 \mathrm{~g}$ & 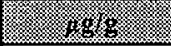 & 3.168 \\
\hline $25-7755$ & $53: 1$ & Whole & $<0.719$ & $<0.718$ & $<0.7185$ \\
\hline $33-7755$ & $54: 1$ & Whole & $<6.15$ & $<6.16$ & $<6.155$ \\
\hline
\end{tabular}

Table B2-94. Tank 241-T-105 Analytical Results: Total Uranium (Laser Fluorimetry).

\begin{tabular}{|c|c|c|c|c|c|}
\hline (1) & S) & 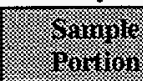 & 178.211 & Emplicate & 1.89. \\
\hline 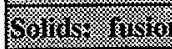 & 3. & 4 & 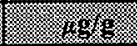 & 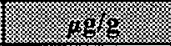 & (3) \\
\hline $25-6740$ & $53: 1$ & Whole & 8,390 & 9,090 & 8,740 \\
\hline $33-6740$ & $54: 1$ & Whole & 10,200 & 8,880 & 9,540 \\
\hline 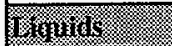 & & (: & $3851411:$ & ( & 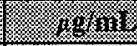 \\
\hline $19-5740$ & $53: 2$ & $\begin{array}{l}\text { Drainable } \\
\text { liquid }\end{array}$ & 8.48 & 7.02 & $7.75^{\mathrm{QC}: \mathrm{c}}$ \\
\hline
\end{tabular}

Table B2-95. Tank 241-T-105 Analytical Results: Hexavalent Chromium $(\mathrm{Cr}+6)$.

\begin{tabular}{|c|c|c|c|c|c|}
\hline Sanile & Sorminge & Sample & resul & Vyublicare & 13rean \\
\hline 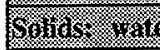 & Hger & & 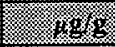 & 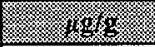 & 48 \\
\hline $25-7769$ & $53: 1$ & Whole & $<18.3$ & $<18.3$ & $<18.3$ \\
\hline $33-7769$ & $54: 1$ & Whole & $<18.3$ & $<18.3$ & $<18.3$ \\
\hline
\end{tabular}


Table B2-96. Tank 241-T-105 Analytical Results: Ammonia (Distillation).

\begin{tabular}{|c|c|c|c|c|c|}
\hline $\begin{array}{l}\text { Simple- } \\
\text { vininiger }\end{array}$ & 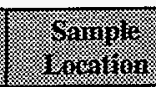 & Simple & resing & Buntichts: & 8 \\
\hline 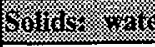 & 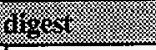 & 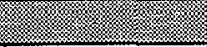 & (1) & $4=\sqrt{1.885}$ & 1.1868 \\
\hline $33-7728$ & $54: 1$ & Whole & $<20$ & $<20$ & $<20$ \\
\hline Thuiris & & & $2.496 \mathrm{gm}$ & 486 or & 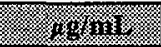 \\
\hline $19-5728$ & $53: 2$ & Drainable liquid & $<400$ & $<400$ & $<400$ \\
\hline
\end{tabular}

Table B2-97. Tank 241-T-105 Analytical Results: pH Measurement.

\begin{tabular}{|c|c|c|c|c|c|}
\hline S.ringls & Larmall & Sampil: & 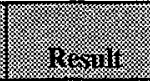 & 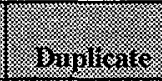 & 48 \\
\hline $2001195: 5$ & (1) & (1) & in: & IIning & iningr. \\
\hline $25-5715$ & $53: 1$ & Whole & 11.31 & 11.27 & 11.29 \\
\hline $33-5715$ & $54: 1$ & Whole & 12.05 & 12.07 & 12.06 \\
\hline Donits & & 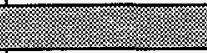 & Iningess & 10 uningsy & 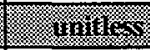 \\
\hline $19-5713$ & $53: 2$ & Drainable liquid & 12 & 12.01 & 12.005 \\
\hline $22-5713$ & $54: 2$ & Drainable liquid & 8.26 & 8.29 . & 8.275 \\
\hline
\end{tabular}

Table B2-98. Tank 241-T-105 Analytical Results: Chloride (IC).

\begin{tabular}{|c|c|c|c|c|c|}
\hline S Simple & 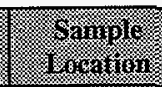 & $\begin{array}{l}\text { Simple } \\
\text { mortion }\end{array}$ & 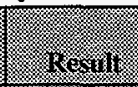 & 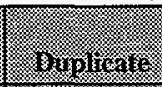 & 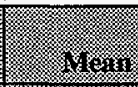 \\
\hline \multicolumn{2}{|c|}{ 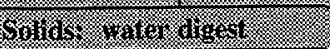 } & $\sqrt{4.8}$ & 3 & 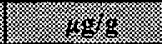 & 8 \\
\hline $25-7771$ & $53: 1$ & Whole & 504 & 517 & 510.5 \\
\hline $33-7771$ & $54: 1$ & Whole & 293 & 294 & 293.5 \\
\hline Livuras: & 4 & 48 & 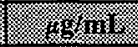 & 10.4 .4 .111 & (19.1.1. \\
\hline $19-5771$ & $53: 2$ & Drainable liquid & 226 & 232 & 229 \\
\hline $22-5771$ & $54: 2$ & Drainable liquid & 8.54 & 9.06 & 8.8 \\
\hline
\end{tabular}


Table B2-99. Tank 241-T-105 Analytical Results: Fluoride (IC).

\begin{tabular}{|c|c|c|c|c|c|}
\hline Samole & 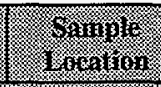 & Samulus & iresint & Bimpirate & Mrivis \\
\hline Irivings & & (2) & 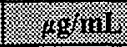 & $869 \mathrm{~s}$. & 3. \\
\hline $19-5771$ & $53: 2$ & Drainable liquid & $<10.1$ & $<10.1$ & $<10.1^{\text {eC:d }}$ \\
\hline $22-5771$ & $54: 2$ & Drainable liquid & 1.26 & 1.26 & 1.26 \\
\hline
\end{tabular}

Table B2-100. Tank 241-T-105 Analytical Results: Nitrate (IC).

\begin{tabular}{|c|c|c|c|c|c|}
\hline (I) & f & Samilo & insing & 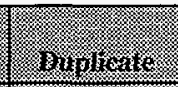 & 12.21 \\
\hline bolins r.me & 1010 & 4 & $.198 \mathrm{~g}$ & 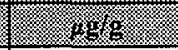 & 3.96 \\
\hline $25-7771$ & $53: 1$ & Whole & 26,400 & 27,400 & 26,900 \\
\hline $33-7771$ & $54: 1$ & Whole & 15,500 & 15,500 & 15,500 \\
\hline Imsinger & & 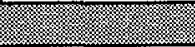 & . & (1) & 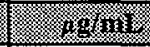 \\
\hline 19-5771 & $53: 2$ & Drainable liquid & 8,060 & 8,180 & 8,120 \\
\hline $22-5771$ & $54: 2$ & Drainable liquid & 5.47 & 5.65 & 5.56 \\
\hline
\end{tabular}

Table B2-101. Tank 241-T-105 Analytical Results: Nitrite (IC).

\begin{tabular}{|c|c|c|c|c|c|}
\hline STIminger & Stringli & 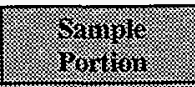 & 8 Resilit. & Bipliones. & 18. \\
\hline \multicolumn{3}{|c|}{ 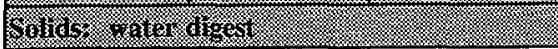 } & (1) & (3) & 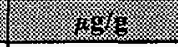 \\
\hline $25-7771$ & $53: 1$ & Whole & 37,000 & 38,700 & 37,850 \\
\hline $33-7771$ & $54: 1$ & Whole & 21,500 & 22,100 & 21,800 \\
\hline 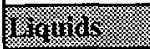 & 3 & & (19610. & 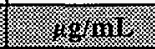 & I: \\
\hline $19-5771$ & $53: 2$ & Drainable liquid & 11,700 & 11,600 & 11,650 \\
\hline $22-5771$ & $54: 2$ & Drainable liquid & 50.3 & 47.8 & 49.05 \\
\hline
\end{tabular}


HNF-SD-WM-ER-369 Rev. 2

Table B2-102. Tank 241-T-105 Analytical Results: Phosphate (IC).

\begin{tabular}{|c|c|c|c|c|c|}
\hline 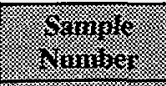 & 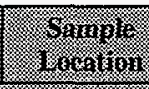 & Somine & Resinis & 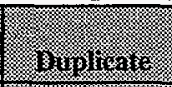 & 6y \\
\hline somins yor & 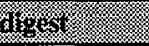 & 4 & 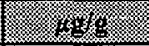 & 8.185 .6 & 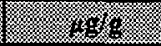 \\
\hline $25-7771$ & $53: 1$ & Whole & 2,670 & 2,550 & 2,610 \\
\hline $33-7771$ & $54: 1$ & Whole & 1,760 & 1,770 & 1,765 \\
\hline Iratids & 8 & 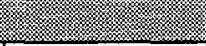 & 108 ini & 3.8 .5111 & 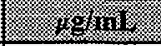 \\
\hline 19-5771 & $53: 2$ & Drainable liquid & 1,600 & 1,560 & 1,580 \\
\hline $22-5771$ & $54: 2$ & Drainable liquid & $<1$ & $<1$ & $<1$ \\
\hline
\end{tabular}

Table B2-103. Tank 241-T-105 Analytical Results: Sulfate (IC).

\begin{tabular}{|c|c|c|c|c|c|}
\hline S4ming & s Staniples & Sarnole & inestit & (4) & 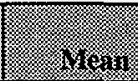 \\
\hline \multicolumn{3}{|c|}{ 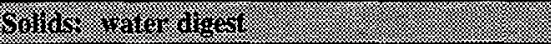 } & 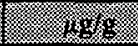 & 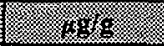 & 8.86 \\
\hline $25-7771$ & $53: 1$ & Whole & 10,700 & 11,000 & 10,850 \\
\hline 33-7771 & $54: 1$ & Whole & 6,210 & 6,290 & 6,250 \\
\hline Munings: & & & (3) & , g.tin: & 8 8. inin \\
\hline $19-5771$ & $53: 2$ & Drainable liquid & 3,480 & 3,500 & 3,490 \\
\hline $22-5771$ & $54: 2$ & Drainable liquid & 41.6 & 41.9 & 41.75 \\
\hline
\end{tabular}

Table B2-104. Tank 241-T-105 Analytical Results: Hydroxide (Titration).

\begin{tabular}{|c|c|c|c|c|c|}
\hline ป. & S Surnore & 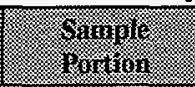 & Itesin: & 8218018020 & iligar \\
\hline 601345 & s. & , & 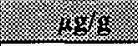 & 8 & 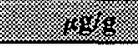 \\
\hline $25-5724$ & 53:1 & Whole & $<1,250$ & $<1,250$ & $<1,250$ \\
\hline $33-5724$ & $54: 1$ & Whole & $<125$ & $<125$ & $<125$ \\
\hline 1.96 & & & 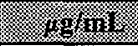 & trgrin: & 8gernin \\
\hline $19-5729$ & $53: 2$ & Drainable liquid & 376 & 357 & 366.5 \\
\hline
\end{tabular}


Table B2-105. Tank 241-T-105 Analytical Results: Cyanide (Distillation/Spectrometry).

\begin{tabular}{|c|c|c|c|c|c|}
\hline S o dingle & Shinily & 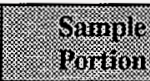 & riresinil: & Bylpilcale & 1. \\
\hline Solins & ! & : & (3) & 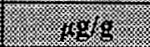 & 1.968 \\
\hline $25-5777$ & $53: 1$ & Ẃhole & 7.85 & 25.1 & $16.475^{\mathrm{QC}: e}$ \\
\hline $33-5777$ & $54: 1$ & Whole & 5.84 & 6.67 & 6.255 \\
\hline
\end{tabular}

Table B2-106. Tank 241-T-105 Analytical Results: Nitrite (Spectrophotometry).

\begin{tabular}{|c|c|c|c|c|c|}
\hline Shaninger & 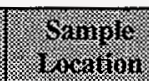 & Sornole & masilin & 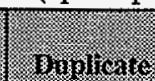 & IIterit \\
\hline \multicolumn{2}{|c|}{ 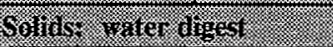 } & 1: & 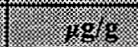 & 1018 & 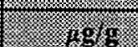 \\
\hline $25-7779$ & $53: 1$ & Whole & 277 & 275 & $276^{\mathrm{QC:c}}$ \\
\hline 33-7779 & $54: 1$ & Whole & 738 & 688 & 713 \\
\hline Myutids & $\sqrt{2}$ & & (1) & $8 / 8 y_{11}$ & (5.8. \\
\hline $19-5779$ & $53: 2$ & Drainable liquid & 17,400 & 17,600 & 17,500 \\
\hline
\end{tabular}

Table B2-107. Tank 241-T-105 Analytical Results: Total Organic Carbon (Furnace Oxidation).

\begin{tabular}{|c|c|c|c|c|c|}
\hline Junite & 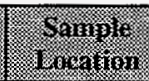 & 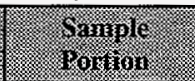 & ligesili & Sinthoste & 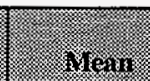 \\
\hline Mrovinge & 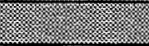 & , & 1.1, & (5) & r \\
\hline $19-5726$ & $53: 2$ & Drainable liquid & 913 & 935 & 924 \\
\hline Soring r w & 18,8 & & 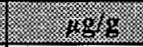 & 108.9 & 8.168. \\
\hline $25-7726$ & $53: 1$ & Whole & 3,960 & 4,290 & 4,125 \\
\hline $33-7726$ & $54: 1$ & Whole & 5,060 & 5,060 & 5,060 \\
\hline
\end{tabular}




\section{HINF-SD-WM-ER-369 Rev. 2}

Table B2-108. Tank 241-T-105 Analytical Results: Total Organic Carbon (Persulfate Oxidation).

\begin{tabular}{|c|c|c|c|c|c|}
\hline Samine & 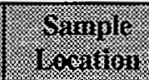 & S & Mesils & Burplizan & (18): \\
\hline 10100 & 1. & 10 & 1.98 & 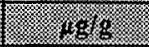 & (2. \\
\hline 93-07986-J1 & $54: 1$ & Whole & 2,790 & 2,440 & 2,615 \\
\hline 93-07987-J1 & $57: 1$ & Whole & 5,380 & 5,180 & 5,280 \\
\hline 93-07988-J1 & $57: 2$ & Whole & 1,630 & 1,630 & 1,630 \\
\hline
\end{tabular}

Table B2-109. Tank 241-T-105 Analytical Results: Total Inorganic Carbon (Persulfate Oxidation).

\begin{tabular}{|c|c|c|c|c|c|}
\hline 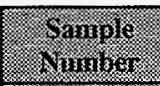 & S3anglo. & $\begin{array}{l}\text { Sample } \\
\text { Somilon }\end{array}$ & Iesini & 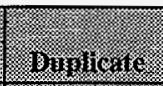 & 40 \\
\hline Sins & & & 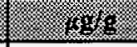 & 8.1 .38 & 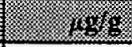 \\
\hline 93-07986-J1 & $54: 1$ & Whole & 4,890 & 4,680 & 4,790 \\
\hline 93-07987-J1 & $57: 1$ & Whole & 4,000 & 3,710 & 3,860 \\
\hline 93-07988-J1 & $57: 2$ & Whole & 3,150 & 3,350 & 3,250 \\
\hline
\end{tabular}

Table B2-110: Tank 241-T-105 Analytical Results: Total Inorganic Carbon:

\begin{tabular}{|c|c|c|c|c|c|}
\hline 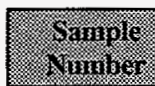 & Saming & 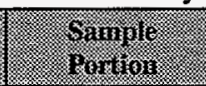 & inesing & Dusilicat & $\sqrt{18}$ \\
\hline \multicolumn{3}{|c|}{ 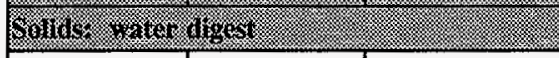 } & - & (1) & $\sqrt{13868}$ \\
\hline $25-7727$ & $53: 1$ & Whole & 7,510 & 7,800 & 7,655 \\
\hline $33-7727$ & $54: 1$ & Whole & 3,850 & 3,500 & 3,675 \\
\hline Hrimas & , & & (.tgini: & 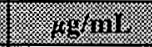 & $\sqrt{18}$ \\
\hline $19-5727$ & $53: 2$ & Drainable liquid & 2,960 & 3,020 & 2,990 \\
\hline
\end{tabular}

Table B2-111. Tank 241-T-105 Analytical Results: Plutonium-238 to Plutonium Ratio (Mass Spectrometry).

\begin{tabular}{|c|c|c|c|c|c|}
\hline - Vuring & (3) & P. & Resitis & Bum & $\sqrt{2} \cdot(2,19$ \\
\hline Soritis r G13 & (1) & & 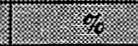 & 4. & 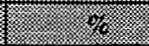 \\
\hline 93-7985-H-1 & $54: 1$ & Whole & 0.193 & 0.19 & 0.1915 \\
\hline
\end{tabular}


Table B2-112. Tank 241-T-105 Analytical Results: Plutonium-239 to Plutonium Ratio (Mass Spectrometry).

\begin{tabular}{|c|c|c|c|c|c|}
\hline $\begin{array}{l}\text { Sarngie } \\
\text { Vurnber: }\end{array}$ & $\begin{array}{l}\text { Samajle: } \\
\text { I goviliou }\end{array}$ & $\begin{array}{l}\text { Saminge } \\
\text { porstin }\end{array}$ & insins & 3hiniluate & (6) \\
\hline 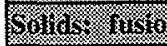 & $\sqrt{3}$ & $\sqrt{7.8}$ & $8 \%$ & 8 & (1. \\
\hline 93-7985-H-1 & $54: 1$ & Whole & 96.469 & 96.239 & 96.354 \\
\hline
\end{tabular}

Table B2-113. Tank 241-T-105 Analytical Results: Plutonium-240 to Plutonium Ratio (Mass Spectrometry).

\begin{tabular}{|c|c|c|c|c|c|}
\hline 8 Sumiles: & Sariale & Sirnigie & 1rosint & Hovicate & $\mathrm{Mer}$ \\
\hline 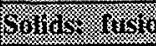 & (4) & (1) & 8. & 4 & \\
\hline 93-7985-H-1 & $54: 1$ & Whole & 3.188 & 3.328 & 3.258 \\
\hline
\end{tabular}

Table B2-114. Tank 241-T-105 Analytical Results: Plutonium-241 to Plutonium Ratio (Mass Spectrometry).

\begin{tabular}{|c|c|c|c|c|c|}
\hline Sumpies & Sarnigle & $\begin{array}{l}\text { Salinil } \\
\text { Protion }\end{array}$ & tresulu & 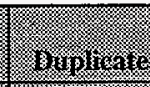 & rewn \\
\hline 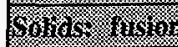 & & 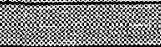 & 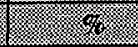 & 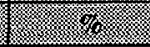 & I) \\
\hline 93-7985-H-1 & $54: 1$ & Whole & 0.11 & 0.16 & $0.135^{\mathrm{QC}: \mathrm{e}}$ \\
\hline
\end{tabular}

Table B2-115. Tank 241-T-105 Analytical Results: Plutonium-242 to Plutonium Ratio (Mass Spectrometry).

\begin{tabular}{|c|c|c|c|c|c|}
\hline $\begin{array}{l}\text { 5imule } \\
\text { tinner }\end{array}$ & 3.1mple & grimale: & iresuit: & ouypticare & 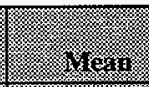 \\
\hline 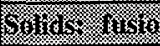 & & স্যে: & (1) & 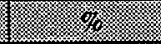 & ) \\
\hline 93-7985-H-1 & $54: 1$ & Whole & 0.04 & 0.08 & $0.06^{\text {QC:e }}$ \\
\hline
\end{tabular}

Table B2-116. Tank 241-T-105 Analytical Results: Uranium-234 to Uranium Ratio (Mass Spectrometry).

\begin{tabular}{|c|c|c|c|c|c|}
\hline 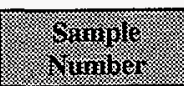 & formals & Shamilo & I. & 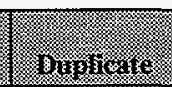 & 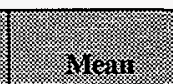 \\
\hline 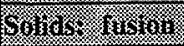 & & (2) & 13 & 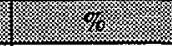 & ( \\
\hline $93-7985-\mathrm{H}-1$ & $54: 1$ & Whole & 0.006 & 0.006 & 0.006 \\
\hline
\end{tabular}


Table B2-117. Tank 241-T-105 Analytical Results: Uranium-235 to Uranium Ratio (Mass Spectrometry).

\begin{tabular}{|c|c|c|c|c|c|}
\hline Shangl & Giangivic & 2. & (2) & 1ringerte & $\sqrt{1.213}$ \\
\hline 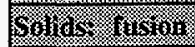 & l: & $\sqrt{\prime}$ & 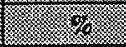 & ) & 10 \\
\hline 93-7985-HI-1 & $54: 1$ & Whole & 0.688 & 0.688 & 0.688 \\
\hline
\end{tabular}

Table B2-118. Tank 241-T-105 Analytical Results: Uranium-236 to Uranium Ratio (Mass Spectrometry).

\begin{tabular}{|c|c|c|c|c|c|}
\hline Siminge & s.mulas & 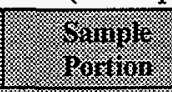 & Resil: & Blyilicate & 13.8. \\
\hline 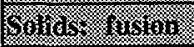 & & $\sqrt{1.13}$ & 8. & $17 \sqrt{30}$ & 1.76. \\
\hline 93-7985-H-1 & $54: 1$ & Whole & 0.006 & 0.006 & 0.006 \\
\hline
\end{tabular}

Table B2-119. Tank 241-T-105 Analytical Results: Uranium-238 to Uranium Ratio (Mass Spectrometry).

\begin{tabular}{|c|c|c|c|c|c|}
\hline $\begin{array}{l}\text { Simples } \\
\text { Tumber }\end{array}$ & Sumpils & Sorinje & (1) & 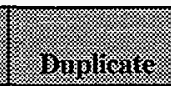 & F \\
\hline 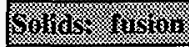 & & W & 2. & (1) & $\sqrt{3}$ \\
\hline 93-7985-H-1 & $54: 1$ & Whole & 99.3 & 99.3 & 99.3 \\
\hline
\end{tabular}

Table B2-120. Tank 241-T-105 Analytical Results: Total Alpha.

\begin{tabular}{|c|c|c|c|c|c|}
\hline 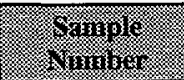 & 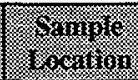 & 6ronole & 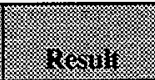 & X) & 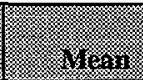 \\
\hline \multicolumn{3}{|c|}{ 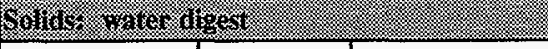 } & 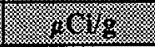 & r. & 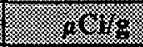 \\
\hline $25-7725$ & $53: 1$ & Whole & 0.00559 & 0.00519 & 0.00539 \\
\hline $33-7725$ & $54: 1$ & Whole & 0.00338 & 0.00345 & 0.003415 \\
\hline Lignar & & & 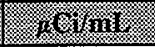 & 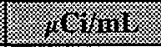 & 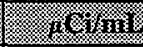 \\
\hline $19-5725$ & $53: 2$ & Drainable liquid & 0.0266 & 0.0285 & $0.02755^{\mathrm{QC:d}}$ \\
\hline Sillus & 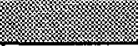 & & , 18 & (1) . 19 & 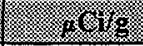 \\
\hline $25-6725$ & $53: 1$ & Whole & 0.815 & 0.823 & 0.819 \\
\hline $33-6725$ & $54: 1$ & Whole & 0.485 & 0.464 & 0.4745 \\
\hline
\end{tabular}


Table B2-121. Tank 241-T-105 Analytical Results: Total Alpha Pu (Alpha Spectrometry).

\begin{tabular}{|c|c|c|c|c|c|}
\hline 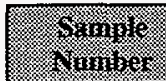 & S4.ningle & 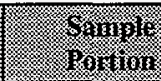 & : & Mariminats & 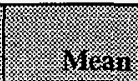 \\
\hline Sormis rite & hest & 4 & 1018 & $486 \operatorname{sig}$ & (1) \\
\hline 93-7985-H-1 & $54: 1$ & Whole & 0.408 & 0.368 & 0.388 \\
\hline
\end{tabular}

Table B2-122. Tank 241-T-105 Analytical Results: Americium-241 (Alpha Spectrometry).

\begin{tabular}{|c|c|c|c|c|c|}
\hline 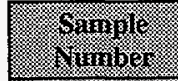 & 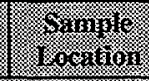 & sampire & Bresili & 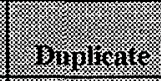 & y. \\
\hline 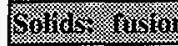 & (2) & (2) & 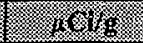 & 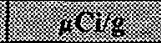 & (3) \\
\hline $25-6782$ & $53: 1$ & Whole & 0.374 & 0.416 & $0.395^{\mathrm{QC}: \mathrm{c}}$ \\
\hline $33-6782$ & $54: 1$ & Whole & 0.0957 & 0.0818 & $0.08875^{\mathrm{QC}: \mathrm{e}}$ \\
\hline Liguras & (-) & 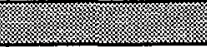 & 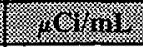 & 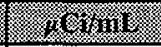 & 1196ris \\
\hline 19-5782 & $53: 2$ & Drainable liquid & $8.270 \mathrm{E}-05$ & $8.290 \mathrm{E}-05$ & $8.280 \mathrm{E}-05^{\mathrm{CC}: c}$ \\
\hline
\end{tabular}

Table B2-123. Tank 241-T-105 Analytical Results: Plutonium-238 (Alpha Spectrometry).

\begin{tabular}{|c|c|c|c|c|c|}
\hline Simitis & 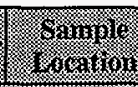 & Sonumis: & Resing & 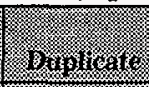 & 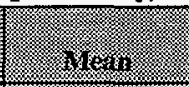 \\
\hline hilginds & (1) & & (1) & 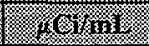 & . \\
\hline $19-5782$ & $53: 2$ & Drainable liquid & $<2.450 \mathrm{E}-04$ & -- & $<2.450 \mathrm{E}-04^{\mathrm{QC}}$ \\
\hline
\end{tabular}

Table B2-124. Tank 241-T-105 Analytical Results: Plutonium-239/40 (Alpha Spectrometry).

\begin{tabular}{|c|c|c|c|c|c|}
\hline 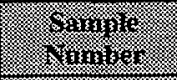 & s.rnous & Stingie & 832513 & Oupiticans: & ren: \\
\hline 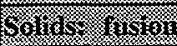 & (1) & & 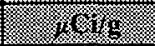 & 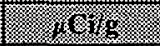 & 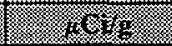 \\
\hline $25-6781$ & $53: 1$ & Whole & 0.137 & 0.135 & 0.136 \\
\hline $33-6781$ & $54: 1$ & Whole & 0.153 & 0.128 & 0.1405 \\
\hline Lraning: & ;) & & 18 (1) & - & $16 \times 10$ \\
\hline 19-5782 & $53: 2$ & Drainable liquid & $1.880 \mathrm{E}-04$ & -- & $1.880 \mathrm{E}-04^{\mathrm{QC}: \mathrm{c}}$ \\
\hline
\end{tabular}


Table B2-125. Tank 241-T-105 Analytical Results: Total Beta (Beta Proportional Counting).

\begin{tabular}{|c|c|c|c|c|c|}
\hline Traminger & $\begin{array}{l}\text { Samine } \\
\text { 8ocalion }\end{array}$ & 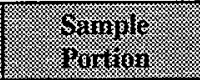 & resin: & Mullis & 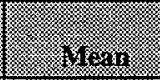 \\
\hline \multicolumn{3}{|c|}{ 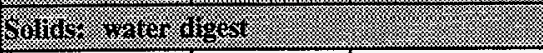 } & 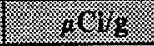 & 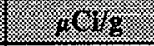 & 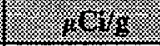 \\
\hline $25-7720$ & $53: 1$ & Whole & 46.9 & 50.2 & 48.55 \\
\hline $33-7720$ & $54: 1$ & Whole & 27.1 . & 26.6 & 26.85 \\
\hline 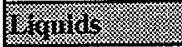 & & & 1017318 & 1. & $10.16 \mathrm{mu}$ \\
\hline $19-5720$ & $53: 2$ & Drainable liquid & 24 & 23.3 & 23.65 \\
\hline Soldids, Tusing & 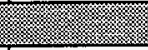 & & (1) & . 10.6 & 1.96 \\
\hline $25-6720$ & $53: 1$ & Whole & 1,260 & $1,250^{\circ}$ & $1,255^{\mathrm{QC}: \mathrm{b}}$ \\
\hline $33-6720$ & $54: 1$ & Whole & 510 & 432 & 471 \\
\hline
\end{tabular}

Table B2-126. Tank 241-T-105 Analytical Results: Strontium-90 (Beta Proportional Counting).

\begin{tabular}{|c|c|c|c|c|c|}
\hline Sompiz: & sompris & 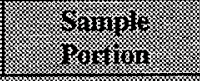 & inestin & Bunitonte. & Mron \\
\hline 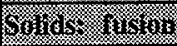 & 1 & & 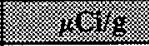 & 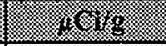 & 8 (3) \\
\hline $25-6782$ & $53: 1$ & Whole & 407 & 395 & 401 \\
\hline $33-6786$ & $54: 1$ & Whole & 173 & 146 & 159.5 \\
\hline Ly rinis: & 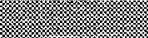 & & 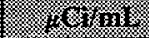 & $1401 \mathrm{ni}$ & Herimin \\
\hline $19-5786$ & $53: 2$ & Drainable liquid & 0.382 & 0.365 & $0.3735^{\mathrm{QC:} \mathrm{a}}$ \\
\hline
\end{tabular}

Table B2-127. Tank 241-T-105 Analytical Results: Americium-241 (GEA).

\begin{tabular}{|c|c|c|c|c|c|}
\hline 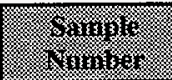 & S sumitic & $\begin{array}{l}\text { Satingli } \\
\text { profigit }\end{array}$ & irentis & 3) & 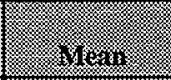 \\
\hline 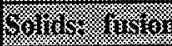 & "प: & & 1.161 .4 & 316 & 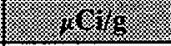 \\
\hline $25-6730$ & 53:1 & Whole & $<0.767$ & $<0.77$ & $<0.7685$ \\
\hline $33-6730$ & $54: 1$ & Whole & $<0.134$ & $<0.125$ & $<0.1295$ \\
\hline \multicolumn{3}{|c|}{ 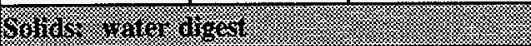 } & 1.263 & 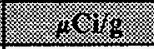 & (1) \\
\hline $25-7730$ & \multirow[t]{2}{*}{$53: 1$} & Whole & $<0.163$ & $<0.164$ & $<0.1635$ \\
\hline $28-9730$ & & Residual solids & 1.3 & 1.64 & $1.47^{\mathrm{QC:e}}$ \\
\hline $33-7730$ & \multirow[t]{2}{*}{$54: 1$} & Whole & $<0.129$ & $<0.13$ & $<0.1295$ \\
\hline $37-9730$ & & Residual solids & 0.296 & 0.193 & $0.2445^{\mathrm{QC}: \mathrm{e}}$ \\
\hline
\end{tabular}


Table B2-128. Tank 241-T-105 Analytical Results: Antimony-125 (GEA).

\begin{tabular}{|c|c|c|c|c|c|}
\hline Trample & 3.1010 & $\begin{array}{l}\text { Samule } \\
\text { Irontior }\end{array}$ & ireral & Buplingrie & 6.18 gra \\
\hline Sorrids & (3. & & 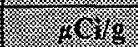 & 1.82, & 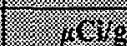 \\
\hline $28-9730$ & $53: 1$ & Residual solids & 0.59 & 0.74 & $0.665^{\mathrm{QC}: e}$ \\
\hline
\end{tabular}

Table B2-129. Tank 241-T-105 Analytical Results: Cerium/Praseodymium-144 (GEA).

\begin{tabular}{|c|c|c|c|c|c|}
\hline Siminge & Soranger & 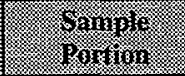 & Recinil & Divinitivis & 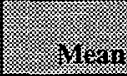 \\
\hline 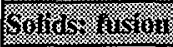 & 4 & & 8.826 .58 & 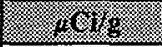 & 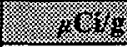 \\
\hline $25-6730$ & $53: 1$ & Whole & $<1.74$ & $<1.74$ & $<1.74$ \\
\hline $33-6730$ & $54: 1$ & Whole & $<0.187$ & $<0.177$ & $<0.182$ \\
\hline Solvs & frget & (s) & (1) & 13 - & 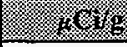 \\
\hline $25-7730$ & \multirow[t]{2}{*}{$53: 1$} & Whole & $<0.243$ & $<0.245$ & $<0.244$ \\
\hline $28-9730$ & & Residual solids & $<0.398$ & $<0.674$ & $<0.536$ \\
\hline 33-7730 & \multirow[t]{2}{*}{$54: 1$} & Whole & $<0.193$ & $<0.194$ & $<0.1935$ \\
\hline $37-9730$ & & Residual solids & $<0.342$ & $<0.207$ & $<0.2745$ \\
\hline
\end{tabular}

Table B2-130. Tank 241-T-105 Analytical Results: Cesium-134 (GEA).

\begin{tabular}{|c|c|c|c|c|c|}
\hline S) & 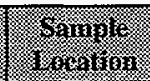 & 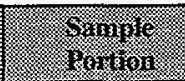 & Iresine & Iupplicis: & 18.11 \\
\hline 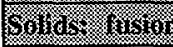 & (3: & !II I I & . 42 & 18. & 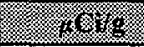 \\
\hline $25-6730$ & $53: 1$ & Whole & $<0.106$ & $<0.0992$ & $<0.1026$ \\
\hline $33-6730$ & $54: 1$ & Whole & $<0.00757$ & $<0.00721$ & $<0.00739$ \\
\hline Sirfins water & Argest & & 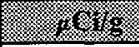 & 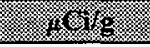 & 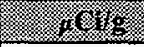 \\
\hline $25-7730$ & \multirow[t]{2}{*}{$53: 1$} & Whole & $<0.0115$ & $<0.0126$ & $<0.01205$ \\
\hline $28-9730$ & & Residual solids & $<0.0173$ & $<0.032$ & $<0.02465$ \\
\hline $33-7730$ & \multirow[t]{2}{*}{$54: 1$} & Whole & $<0.0112$ & $<0.012$ & $<0.0116$ \\
\hline $37-9730$ & & Residual solids & $<0.0116$ & $<0.00761$ & $<0.009605$ \\
\hline
\end{tabular}


Table B2-131. Tank 241-T-105 Analytical Results: Cesium-137 (GEA).

\begin{tabular}{|c|c|c|c|c|c|}
\hline Samples & STrmplo & $\begin{array}{l}\text { Sample } \\
\text { Iortina }\end{array}$ & I (eraili & 3430110412 & Near \\
\hline 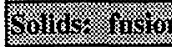 & & সায় & 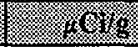 & (2) & 1) \\
\hline $25-6730$ & $53: 1$ & Whole & 61 & 62.7 & 61.85 \\
\hline $33-6730$ & $54: 1$ & Whole & 38.1 & 35.2 & 36.65 \\
\hline 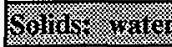 & thengers. & & $\sqrt{1.13}$ & $\sqrt{17.18}$ & 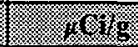 \\
\hline $25-7730$ & \multirow[t]{2}{*}{$53: 1$} & Whole & 40.7 & 40.8 & 40.75 \\
\hline $28-9730$ & & Residual solids & 53.3 & 77.92 & $65.61^{\mathrm{eC}: 0}$ \\
\hline $33-7730$ & \multirow[t]{2}{*}{$54: 1$} & Whole & 23.9 & 23.8 & 23.85 \\
\hline $37-9730$ & & Residual solids & 57.5 & 33.5 & $45.5^{Q<: 0}$ \\
\hline
\end{tabular}

Table B2-132. Tank 241-T-105 Analytical Results: Cobalt-60 (GEA).

\begin{tabular}{|c|c|c|c|c|c|}
\hline VImaliter & (8). & O & insing & 8ing II. & ingen \\
\hline Sontis Urision & & & 1.0 .88 & 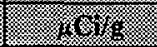 & 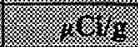 \\
\hline $25-6730$ & $53: 1$ & Whole & $<0.0909$ & $<0.0913$ & $<0.0911$ \\
\hline $33-6730$ & $54: 1$ & Whole & $<0.00688$ & 0.0195 & $<0.01319$ \\
\hline bolins vares & 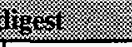 & & 10.8. & $10 \% 8$ & 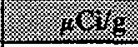 \\
\hline $25-7730$ & \multirow[t]{2}{*}{$53: 1$} & Whole & $<0.0136$ & $<0.0131$ & $<0: 01335$ \\
\hline $28-9730$ & & Residual solids & 0.043 & 0.0634 & $0.0532^{\mathrm{QC: \theta}}$ \\
\hline $33-7730$ & \multirow[t]{2}{*}{$54: 1$} & Whole & $<0.0117$ & $<0.0119$ & $<0.0118$ \\
\hline $37-9730$ & & Residual solids & 0.0254 & 0.0213 & 0.02335 \\
\hline
\end{tabular}




\section{HNF-SD-WM-ER-369 Rev. 2}

Table B2-133. Tank 241-T-105 Analytical Results: Europium-154 (GEA).

\begin{tabular}{|c|c|c|c|c|c|}
\hline Cramilor & f Shanule & 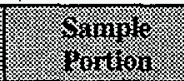 & inesil: & 3uplnate & 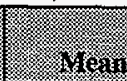 \\
\hline 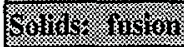 & 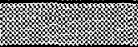 & $\sqrt{18}$ & 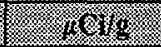 & (1) & 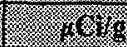 \\
\hline $25-6730$ & $53: 1$ & Whole & 1.24 & $<0.295$ & $<0.7675$ \\
\hline $33-6730$ & $54: 1$ & Whole & 0.247 & 0.218 & 0.2325 \\
\hline \multicolumn{3}{|c|}{ 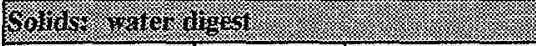 } & 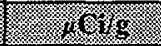 & (1) & f \\
\hline $25-7730$ & \multirow[t]{2}{*}{$53: 1$} & Whole & $<0.0372$ & $<0.0371$ & $<0.03715$ \\
\hline $28-9730$ & & Residual solids & 2.7 & 3.3 & 3 \\
\hline $33-7730$ & \multirow[t]{2}{*}{$54: 1$} & Whole & $<0.0418$ & $<0.0344$ & $<0.0381$ \\
\hline $37-9730$ & & Residual solids & 0.71 & 0.438 & $0.574^{\mathrm{eC}: \mathrm{s}}$ \\
\hline
\end{tabular}

Table B2-134. Tank 241-T-105 Analytical Results: Europium-155 (GEA).

\begin{tabular}{|c|c|c|c|c|c|}
\hline Samis & $\begin{array}{c}\text { Sampile } \\
\text { I. }\end{array}$ & Sormils & inguis & 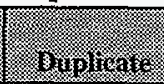 & . \\
\hline Sorigs & 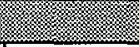 & $\sqrt{2}$ & $1.2 \times 145$ & 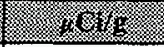 & 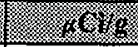 \\
\hline $25-6730$ & $53: 1$ & Whole & 1.19 & $<0.486$ & $<0.838$ \\
\hline $33-6730$ & $54: 1$ & Whole & 0.216 & 0.196 & 0.206 \\
\hline 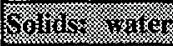 & dist & 4 & 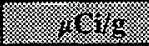 & 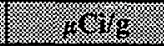 & 1. \\
\hline $25-7730$ & \multirow[t]{2}{*}{$53: 1$} & Whole & $<0.0748$ & $<0.0743$ & $<0.07455$ \\
\hline $28-9730$ & & Residual solids & 3.2 & 4 & $3.6^{\mathrm{QC}: \mathrm{c}}$ \\
\hline $33-7730$ & \multirow[t]{2}{*}{$54: 1$} & Whole & $<0.0583$ & $<0.0592$ & $<0.05875$ \\
\hline $37-9730$ & & Residual solids & 0.761 & 0.484 & $0.6225^{\text {QC:c }}$ \\
\hline
\end{tabular}


Table B2-135. Tank 241-T-105 Analytical Results: Potassium-40 (GEA).

\begin{tabular}{|c|c|c|c|c|c|}
\hline Sarmile & Simorilion & onmaile & Tesint & $83 \ln 1 \mathrm{ic} 1 \mathrm{r}$ & N/4: \\
\hline S & 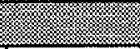 & স্য: & 4.13013 & 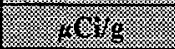 & 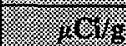 \\
\hline $25-6730$ & $53: 1$ & Whole & $<2.95$ & $<2.92$ & $<2.935$ \\
\hline $33-6730$ & $54: 1$ & Whole & $<0.152$ & $<0.151$ & $<0.1515$ \\
\hline 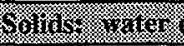 & 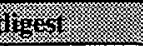 & (2) & (5) & 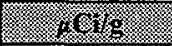 & 48 \\
\hline $25-7730$ & \multirow[t]{2}{*}{$53: 1$} & Whole & 0.324 & $<0.322$ & $<0.323$ \\
\hline $28-9730$ & & Residual solids & $<0.0562$ & $<0.099$ & $<0.0776$ \\
\hline 33-7730 & \multirow[t]{2}{*}{$54: 1$} & Whole & 0.396 & 0.316 & $0.356^{\mathrm{QC}: e}$ \\
\hline $37-9730$ & & Residual solids & $<0.0606$ & $<0.0353$ & $<0.04795$ \\
\hline
\end{tabular}

Table B2-136. Tank 241-T-105 Analytical Results: Ruthenium-103 (GEA).

\begin{tabular}{|c|c|c|c|c|c|}
\hline $\begin{array}{l}\text { Samules } \\
\text { Namiars }\end{array}$ & $\begin{array}{l}\text { 5grinjis } \\
\text {. }\end{array}$ & 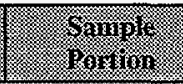 & Resuil & 3) & Vrarn \\
\hline \multicolumn{3}{|c|}{ 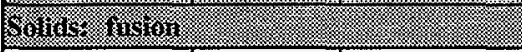 } & 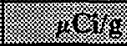 & 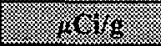 & 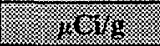 \\
\hline $25-6730$ & $53: 1$ & Whole & $<0.164$ & $<0.164$ & $<0.164$ \\
\hline $33-6730$ & $54: 1$ & Whole & $<0.0236$ & $<0.023$ & $<0.0233$ \\
\hline \multicolumn{3}{|c|}{ 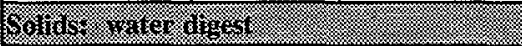 } & 4.168 & 8.96 & 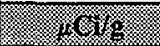 \\
\hline $25-7730$ & \multirow[t]{2}{*}{$53: 1$} & Whole & $<0.0354$ & $<0.0353$ & $<0.03535$ \\
\hline $28-9730$ & & Residual solids & $<0.0244$ & $<0.0438$ & $<0.0341$ \\
\hline $33-7730$ & \multirow[t]{2}{*}{$54: 1$} & Whole & $<0.0274$ & $<0.0275$ & $<0.02745$ \\
\hline $37-9730$ & & Residual solids & $<0.0245$ & $<0.015$ & $<0.01975$ \\
\hline
\end{tabular}


Table B2-137. Tank 241-T-105 Analytical Results: Ruthenium/Rhodium-106 (GEA).

\begin{tabular}{|c|c|c|c|c|c|}
\hline $\begin{array}{l}\text { Sarmole } \\
\text { Sknite- }\end{array}$ & Sarnjols & $\begin{array}{l}\text { Simigie } \\
\text { Poftion }\end{array}$ & ivstil & 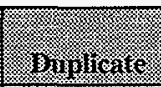 & - \\
\hline 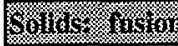 & & 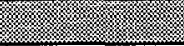 & 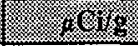 & - & 2 848 \\
\hline $25-6730$ & $53: 1$ & Whole & $<1.93$ & $<2.14$ & $<2.035$ \\
\hline $33-6730$ & $54: 1$ & Whole & $<0.31$ & $<0.296$ & $<0.303$ \\
\hline S. & 10.6. & & (1) & (6) & (18) \\
\hline 25-7730 & \multirow[t]{2}{*}{$53: 1$} & Whole & $<0.451$ & $<0.482$ & $<0.4665$ \\
\hline $28-9730$ & & Residual solids & $<0.34$ & $<0.621$ & $<0.4805$ \\
\hline 33-7730 & \multirow[t]{2}{*}{$54: 1$} & Whole & $<0.391$ & $<0.385$ & $<0.388$ \\
\hline $37-9730$ & & Residual solids & $<0.31$ & $<0.19$ & $<0.25$ \\
\hline
\end{tabular}

Table B2-138. Tank 241-T-105 Analytical Results: Thorium-228 (GEA).

\begin{tabular}{|c|c|c|c|c|c|}
\hline Sarivile & 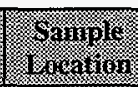 & (2) & renuli & Silinilone & 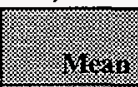 \\
\hline 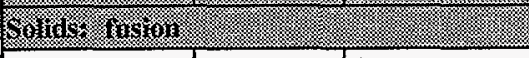 & \multicolumn{2}{|c|}{$\sqrt{4}$} & 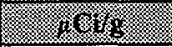 & $\sqrt{1.8}$ & 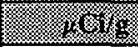 \\
\hline $25-6730$ & $53: 1$ & Whole & $<0.261$ & $<0.268$ & $<0.2645$ \\
\hline $33-6730$ & $54: 1$ & Whole & $<0.0355$ & $<0.0336$ & $<0.03455$ \\
\hline \multicolumn{3}{|c|}{ 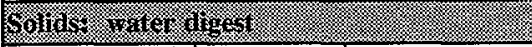 } & 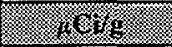 & 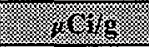 & 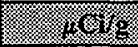 \\
\hline $25-7730$ & \multirow[t]{2}{*}{$53: 1$} & Whole & $<0.0517$ & $<0.0514$ & $<0.05155$ \\
\hline $28-9730$ & & Residual solids & $<0.048$ & $<0.0828$ & $<0.0654$ \\
\hline $33-7730$ & \multirow[t]{2}{*}{$54: 1$} & Whole & $<0.0409$ & $<0.0414$ & $<0.04115$ \\
\hline $37-9730$ & & Residual solids & $<0.0456$ & $<0.0279$ & $<0.03675$ \\
\hline
\end{tabular}


HNF-SD-WM-ER-369 Rev. 2

Table B2-139. Tank 241-T-105 Analytical Results: Carbon-14 (Liquid Scintillation).

\begin{tabular}{|c|c|c|c|c|c|}
\hline S.oringl & S Sormint & Samornole & Resil & nivintig t & $\sqrt{18}$ \\
\hline \multicolumn{2}{|c|}{ 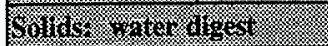 } & & 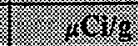 & 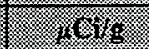 & 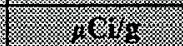 \\
\hline $28-7788$ & $53: 1$ & Whole & $9.270 \mathrm{E}-04$ & 0.00173 & $0.0013285^{\mathrm{eC}: a, \mathrm{C}}$ \\
\hline $37-7788$ & $54: 1$ & Whole & $5.850 \mathrm{E}-04$ & $7.840 \mathrm{E}-04$ & $6.845 \mathrm{E}-04^{\mathrm{QC}: 0}$ \\
\hline
\end{tabular}

Table B2-140. Tank 241-T-105 Analytical Results: Tritium (Liquid Scintillation).

\begin{tabular}{|c|c|c|c|c|c|}
\hline 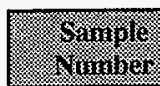 & 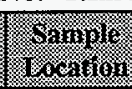 & $\begin{array}{l}\text { Saminle: } \\
\text { rontion }\end{array}$ & 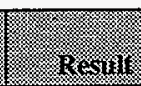 & implicus & $\sqrt{18}$ \\
\hline \multicolumn{2}{|c|}{ Suling: viler angest } & $4=$ & 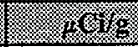 & 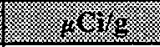 & 䇛 \\
\hline $28-7787$ & $53: 1$ & Whole & 0.0227 & 0.0253 & $0.024^{\mathrm{QC:c}}$ \\
\hline $37-7787$ & $54: 1$ & Whole & $4.140 \mathrm{E}-04$ & 0.00132 & $8.670 \mathrm{E}-04^{\mathrm{OC}: \mathrm{c}}$ \\
\hline
\end{tabular}

Table B2-141. Tank 241-T-105 Analytical Results: Technetium-99 (Liquid Scintillation).

\begin{tabular}{|c|c|c|c|c|c|}
\hline Sirnive & Sirnolle & $\begin{array}{l}\text { Sample } \\
\text { Barions }\end{array}$ & Iresil: & 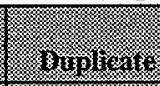 & 18ar: \\
\hline 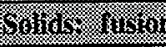 & & 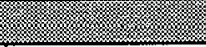 & 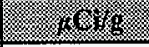 & 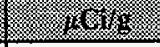 & 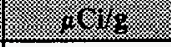 \\
\hline $25-6782$ & $53: 1$ & Whole & $<0.17$ & $<0.167$ & $<0.1685^{\mathrm{QC}: \mathrm{c}}$ \\
\hline $33-6784$ & $54: 1$ & Whole & 0.399 & 0.345 & $0.372^{\mathrm{QC}: \mathrm{c}}$ \\
\hline Hiquin: & ) & & . & ( & 840.4311 \\
\hline $19-5784$ & $53: 2$ & Drainable liquid & 0.0649 & 0.0605 & $0.0627^{\mathrm{ec}: \mathrm{c}}$ \\
\hline
\end{tabular}

Table B2-142. Tank 241-T-105 Analytical Results: Weight Percent Solids (Percent Solids).

\begin{tabular}{|c|c|c|c|c|c|}
\hline Simivis & 3.ming & $\begin{array}{l}\text { Simple } \\
\text { Leortine }\end{array}$ & Restit: & nitsingen & (3) \\
\hline Somis & স্যে: & স্যে & 4 & 83 & 8.8 \\
\hline $33-5710$ & $54: 1$ & Whole & 73.48 & 73.29 & 73.385 \\
\hline 93-09787 & $57: 1$ & Whole & 52 & - & 52 \\
\hline 93-09788 & $57: 2$ & Whole & 75 & $-\cdots$ & 75 \\
\hline 93-07985-K & $54: 1$ & Whole & 74.9 & 76.3 & 75.6 \\
\hline
\end{tabular}


Table B2-143. Tank 241-T-105 Analytical Results: Weight Percent Centrifuged Solids (Physical Properties).

\begin{tabular}{|c|c|c|c|c|c|}
\hline Sulingle & ofrmiple & 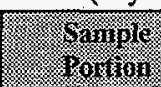 & insing & Fum & . \\
\hline Silor & l, & $\sqrt{4.8}$ & 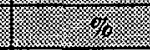 & 6 & স \\
\hline 93-09787 & $57: 1$ & Whole & 98 & -- & 98 \\
\hline
\end{tabular}

Table B2-144. Tank 241-T-105 Analytical Results: Weight Percent Residual Solids (Percent Solids).

\begin{tabular}{|c|c|c|c|c|c|}
\hline 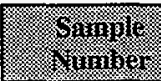 & S Simple & 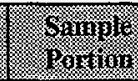 & $18=311$ & Higlicica & Vile, \\
\hline 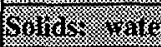 & II & (1) & $\sqrt{2.8}$ & 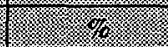 & $\sqrt{85:}$ \\
\hline $37-9710$ & $54: 1$ & Whole & 37.95 & 67.48 & $52.715^{\mathrm{QC:c}}$ \\
\hline
\end{tabular}

Table B2-145. Tank 241-T-105 Analytical Results: Density (Physical Properties).

\begin{tabular}{|c|c|c|c|c|c|}
\hline Single & 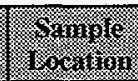 & S Simile & isecysil & 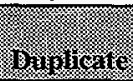 & Mesin \\
\hline \multicolumn{3}{|c|}{ boriar } & (2. 511 & 8.011 & 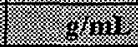 \\
\hline Not given & $53: 1$ & Whole & $0.89^{1}$ & --- & 0.89 \\
\hline Not given & $54: 1$ & Whole & $2.01^{1}$ & --- & 2.01 \\
\hline 93-09787 & \multirow[t]{4}{*}{$57: 1$} & Whole & $1.1^{1}$ & $\cdots$ & 1.1 \\
\hline 93-09787 & & Whole (1:3 dilution) & $1.03^{2}$ & $\overline{-\cdots}$ & 1.03 \\
\hline $93-09787$ & & Whole (1:1 dilution) & $1.12^{2}$ & $\ldots$ & 1.12 \\
\hline $93-09787$ & & Whole & $1.54^{2}$ & $\overline{---}$ & 1.54 \\
\hline 93-09788 & \multirow[t]{2}{*}{$57: 2$} & Whole & $1.07^{1}$ & -- & 1.07 \\
\hline $93-09788$ & & Whole & $1.74^{2}$ & $--\cdot$ & 1.74 \\
\hline \multicolumn{3}{|c|}{ 18unis: } & (3) & 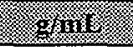 & (3) \\
\hline Not given & $53: 2$ & Drainable liquid & $0.88^{1}$ & -- & 0.88 \\
\hline Not given & $54: 1$ & Drainable liquid & $1.48^{1}$ & -- & 1.48 \\
\hline Not given & $54: 2$ & Drainable liquid & $0.97^{1}$ & $\ldots$ & 0.97 \\
\hline
\end{tabular}

Notes:

'Density estimated by dividing sample mass by the sample volume

${ }^{2}$ Analytically measured density 
Table B2-146. Tank 241-T-105 Analytical Results: Density of Solids Centrifuged from Supernatant (Physical Properties).

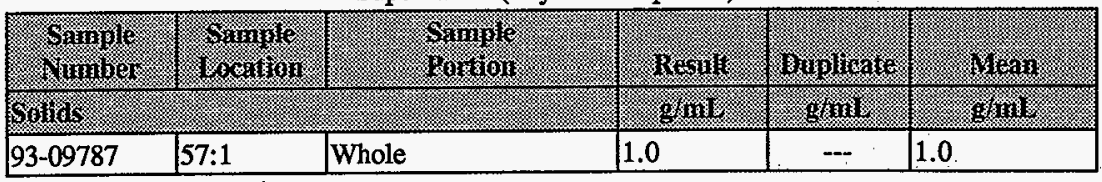

Table B2-147. Tank 241-T-105 Analytical Results: Centrifuged Solids Density (Physical Properties).

\begin{tabular}{|c|c|c|c|c|c|}
\hline $\begin{array}{l}\text { Siminile } \\
\text { Jininger }\end{array}$ & Srmule & 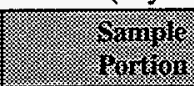 & itesial & 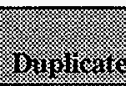 & $\sqrt{1.5}$ \\
\hline (6) & & ) & 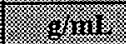 & 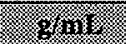 & (8) 11 \\
\hline $93-09787$ & $57: 1$ & Whole & 1.56 & -- & 1.56 \\
\hline
\end{tabular}

Table B2-148. Tank 241-T-105 Analytical Results: Specific Gravity.

\begin{tabular}{|c|c|c|c|c|c|}
\hline 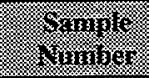 & Siminge & 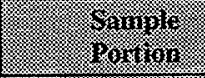 & resilis & Minlinate & 18aris \\
\hline is oulas & 篻 & 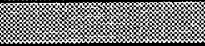 & initirs: & 1) & 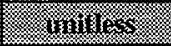 \\
\hline $19-5706$ & $53: 2$ & Drainable liquid & 1.05 & 1.05 & 1.05 \\
\hline $22-5706$ & $54: 2$ & Drainable liquid & 0.986 & 0.984 & 0.985 \\
\hline
\end{tabular}

Table B2-149. Tank 241-T-105 Analytical Results: Volume Percent Settled Solids (Physical Properties).

\begin{tabular}{|c|c|c|c|c|c|}
\hline Siminger & 8.mingin: & 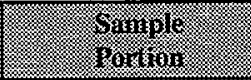 & (1) & Brivulutar & 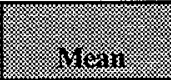 \\
\hline \multicolumn{3}{|l|}{ Sords } & \multirow[t]{2}{*}{. } & "I: & I \\
\hline 93-09787 & \multirow[t]{3}{*}{$57: 1$} & Whole (1:3 dilution) & & -- & 39 \\
\hline $93-09787$ & & Whole (1:1 dilution) & 70 & -- & 70 \\
\hline 93-09787 & & Whole & 100 & - & 100 \\
\hline 93-09788 & \multirow[t]{3}{*}{$57: 2$} & Whole (1:3 dilution) & 17 & - & 17 \\
\hline $93-09788$ & & Whole (1:1 dilution) & 31 & -- & 31 \\
\hline 93-09788 & & Whole & 100 & $-\cdots$ & 100 \\
\hline
\end{tabular}


Table B2-150. Tank 241-T-105 Analytical Results: Volume Percent Centrifuged Solids (Physical Properties).

\begin{tabular}{|c|c|c|c|c|c|}
\hline $\begin{array}{l}\text { Shininte } \\
\text { Naniber }\end{array}$ & 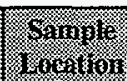 & Thinile & (3esil) & Bujicare & W18. \\
\hline Sing & $\sqrt{7}$ & lis & , & 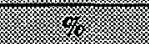 & 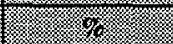 \\
\hline 93-09787 & $57: 1$ & Whole & 96 & -- & 96 \\
\hline 93-09788 & $57: 2$ & Whole & 98 &.-- & 98 \\
\hline
\end{tabular}

Table B2-151. Tank 241-T-105 Analytical Results: Total Dissolved Solids (Percent Solids).

\begin{tabular}{|c|c|c|c|c|c|}
\hline 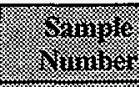 & Sancilin & romarau & Rrerin & Bujinicion & 14 (4) \\
\hline Solidis & Migesi & 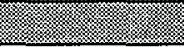 & $4=$ & 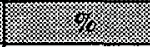 & 1 \\
\hline $25-7705$ & 53:1 & Whole & 0.24 & 0.32 & $0.28^{\mathrm{QC}: \mathrm{e}}$ \\
\hline $33-7705$ & $54: 1$ & Whole & 0.09 & 0.12 & $0.105^{\mathrm{QC}: c}$ \\
\hline
\end{tabular}

Table B2-152. Tank 241-T-105 Analytical Results: Consistency Factor (Physical Properties).

\begin{tabular}{|c|c|c|c|c|c|}
\hline Sanme: & 89molit & 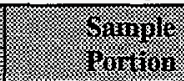 & iresul: & G.13inditice & $81 \log 1$ \\
\hline Sillon & (3) & : & 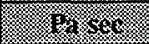 & 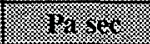 & f: \\
\hline 93-07987 & $57: 1$ & $\begin{array}{l}\text { Whole } \\
\text { (1:1 dilution) }\end{array}$ & 0.036 & 0.028 & $0.032^{\mathrm{QC:c}}$ \\
\hline
\end{tabular}

Table B2-153. Tank 241-T-105 Analytical Results: Flow Behavior Index (Physical Properties).

\begin{tabular}{|c|c|c|c|c|c|}
\hline 7inisie & 800.710 & Somple & ricsun: & Ginilicate & llerin \\
\hline Son & 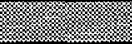 & $\sqrt{10}$ & Iraitile & (1) 1145 & ( \\
\hline 93-07987 & $57: 1$ & $\begin{array}{l}\text { Whole } \\
\text { (1:1 dilution) }\end{array}$ & .074 & 0.86 & 0.8 \\
\hline
\end{tabular}


Table B2-154. Tank 241-T-105 Analytical Results: Yield Point (Physical Properties).

\begin{tabular}{|c|c|c|c|c|c|}
\hline $\begin{array}{l}\text { Surnile } \\
\text { Sonote }\end{array}$ & Irocation & lo & 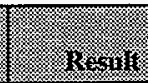 & 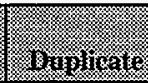 & heran \\
\hline 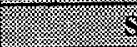 & & I) & 8 & 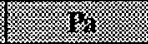 & 48 \\
\hline 93-07987 & $57: 1$ & Whole & 6.8 & 6.0 & 6.4 \\
\hline
\end{tabular}

Table B2-155. Tank 241-T-105 Analytical Results: Exothermic Results (DSC).

\begin{tabular}{|c|c|c|c|c|c|c|}
\hline 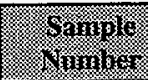 & 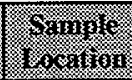 & $\begin{array}{l}\text { iamiple } \\
\text { qoufon }\end{array}$ & Thanculvon & inesum & Binnlicine & Hean \\
\hline 1810s & I & $\sqrt{ }$ & & $1 / 58$ & 18 & (1) \\
\hline 93-07987 & $57: 1$ & Whole & 2 & 167 & 180 & 174 \\
\hline $9-5711$ & $53: 1$ & Whole & 2 & 30.3 & -- & 13 \\
\hline
\end{tabular}

Table B2-156. Tank 241-T-105 Analytical Results: Percent Water (TGA).

\begin{tabular}{|c|c|c|c|c|c|}
\hline vaninge & S & samill & Rzerill & 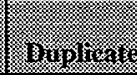 & 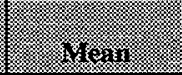 \\
\hline (n) & 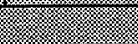 & 8 & 4 & 4 & U: \\
\hline $9-5712$ & $53: 1$ & Whole & 51.97 & $\ldots$ & 51.97 \\
\hline $8-5712$ & $54: 1$ & Whole & 35.52 & -- & 35.52 \\
\hline $93-07987$ & $57: 1$ & Whole & 48.7 & 46.5 & 47.6 \\
\hline $93-07988$ & $57: 2$ & Whole & 19.8 & 19.1 & 20 \\
\hline I iniming & 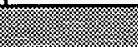 & & 18 & 18 & (1) \\
\hline $19-5712$ & $53: 2$ & Drainable liquid & 91.42 & 91.36 & 91.39 \\
\hline
\end{tabular}




\section{B3.0 ASSESSMENT OF CHARACTERIZATION RESULTS}

This section discusses the overall quality and consistency of the current sampling results for tank 241-T-105 and provides the results of an analytical-based inventory calculation.

This section also evaluates sampling and analysis factors that may impact data interpretation. These factors are used to assess overall data quality and consistency and to identify limitations in data use. The assessments are based only on the 1997 core sample results.

\section{B3.1 FIELD OBSERVATIONS}

Sample recovery for the 1997 samples was generally good except for core 205 , segment 4 , in which the valve was open resulting in a poor sample recovery. Segment 1 of core 207 and segment 2 of core 205 contained clear and dark crystals which could not be broken up in the laboratory. Two segments were obtained from both cores. Liner liquid in core 207 was mostly hydrostatic head fluid. Except for the open valve, samples were obtained without incident.

\section{B3.2 QUALITY CONTROL ASSESSMENT}

The usual QC assessment includes an evaluation of the appropriate standard recoveries, spike recoveries, duplicate analyses, and blanks that are performed in conjunction with chemical analyses. All pertinent QC tests were conducted on the 1997 samples. The SAP (Field 1997) established specific criteria for all analytes. Sample and duplicate pairs, which had one or more $\mathrm{QC}$ results outside the specified criteria, were identified by superscripts in the data summary tables.

As noted previously, the QC review for IC and ICP analyses was limited to only those analytes requested (that is. bromide and lithium). Other IC and ICP analytes are listed in the data tables but are considered "opportunistic." Specific quality checks and reviews for these analytes were not conducted.

The standard and spike recovery results provide an estimate of analysis accuracy. If a standard or spike recovery is above or below the given criterion, the analytical results may be biased high or low, respectively. The precision is estimated by the RPD, which is defined as the absolute value of the difference between the primary and duplicate samples, divided by their mean, times 100 . 
The standard recoveries, RPDs, and spike recoveries were within the required limits for most analytes. Total alpha results had a high RPD for one drainable liquid sample, but this was attributed to an alpha activity near the detection limit; no reruns were requested. No sample exceeded the criterion for preparation blanks; therefore, contamination was not a problem.

In summary, the vast majority of QC results were within the boundaries specified in the SAPs. The discrepancies mentioned here and footnoted in the data summary tables should not impact data validity or use.

\section{B3.3 DATA CONSISTENCY CHECKS}

Comparisons of different analytical methods can help to assess data consistency and quality. Several correlations were possible with the data set provided by the two core samples, including comparisons of phosphorous and sulfur as analyzed by ICP with phosphate and sulfate as analyzed by IC. In addition, mass and charge balances were calculated to help assess overall data consistency.

\section{B3.3.1 Comparison of Results from Different Analytical Methods}

The following data consistency checks compare results from two analytical methods. Close agreement between the two methods strengthens the credibility of both results, but a poor agreement brings the reliability of the data into question.

Phosphorus is determined by ICP, and phosphate is determined by IC. Assuming that all phosphorus is present as phosphate yielded mean sludge concentrations of $4,505 \mu \mathrm{g} / \mathrm{g}$ for the acid-digested sample. The phosphate value by IC was $2,840 \mu \mathrm{g} / \mathrm{g}$. This indicates about 63 percent of the phosphorous is water soluble. For drainable liquid, the phosphate value from ICP was $4,995 \mu \mathrm{g} / \mathrm{mL}$. This compares reasonably well with the phosphate IC value of $4,560 \mu \mathrm{g} / \mathrm{mL}$ for drainable liquid, indicating that nearly all the phosphorus in the drainable liquid is present as phosphate.

Sulfur is considered to be present as the sulfate ion and appears to be completely water soluble: The sulfate concentrations calculated from the ICP acid digest for sulfur were 8,640 . This value is below the IC water-digested sulfate concentration of $9,450 \mu \mathrm{g} / \mathrm{g}$. The values for drainable liquid were $16,320 \mu \mathrm{g} / \mathrm{mL}$ for sulfate calculated from the ICP value for sulfur and $15,700 \mu \mathrm{g} / \mathrm{mL}$ for sulfate by IC. 


\section{B3.3.2 Mass and Charge Balances}

The principle objective in performing mass and charge balances is to determine whether measurements are consistent. Mass and charge balances were calculated separately for sludge and drainable liquid analytical results. The mass and charge balance calculations include only those analytes listed in Section B3.4 which were detected at a concentration of $1,000 \mu \mathrm{g} / \mathrm{g}$ $(1,000 \mu \mathrm{g} / \mathrm{mL}$ for drainable liquids) or greater.

B3.3.2.1 Solids. Except for sodium and bismuth, all analytes were assumed to be present in their most common hydroxide, or oxide forms. Because precipitates are neutral species, all positive charge was attributed to the sodium cations. Bismuth was assumed to be present as bismuth phosphate.

The anions were assumed to be present as sodium salts and were expected to balance the positive charge exhibited by the cations. The concentrations of the cations listed in Table B3-1, the anions listed in Table B3-2, and the weight percent water results were ultimately used to calculate the mass balance. The mass balance can be calculated from the formula below. The factor 0.0001 is the conversion factor from $\mu \mathrm{g} / \mathrm{g}$ to weight percent.

$$
\begin{aligned}
\text { Mass balance }= & \% \text { Water }+0.0001 \times\{\text { Total Analyte Concentration }\} \\
=\quad & \% \text { Water }+0.0001 \times\left\{\left[\mathrm{Al}(\mathrm{OH})_{3}\right]+\left[\mathrm{BiPO}_{4}\right]+[\mathrm{FeO}(\mathrm{OH})]+\left[\mathrm{MnO}_{2}\right]\right. \\
& +\left[\mathrm{Na}^{+}\right]+\left[\mathrm{SiO}_{2}\right]+\left[\mathrm{NO}_{3}^{-}\right]+\left[\mathrm{NO}_{2}{ }^{2}\right]+\left[\mathrm{PO}_{4}{ }_{4}{ }^{2}\right]+\left[\mathrm{SO}_{4}{ }^{2-}\right]+ \\
& {\left.\left[\mathrm{UO}_{2}{ }^{2+}\right]\right\} }
\end{aligned}
$$

The total analyte concentration calculated from the above equation was $402,400 \mu \mathrm{g} / \mathrm{g}$. The mean weight percent water was 60.4 percent, as determined by TGA. The mass balance resulting from adding the weight percent water to the total analyte concentration was 100.6 percent, as shown in Table B3-3.

The charge balance is the ratio of total cations $(\mu \mathrm{eq} / \mathrm{g})$ to total anions $(\mu \mathrm{eq} / \mathrm{g})$.

Total cations $(\mu \mathrm{eq} / \mathrm{g})=\left[\mathrm{Na}^{+}\right] / 23.0+\left[\mathrm{UO}_{2}{ }^{2+}\right] / 135=+2,810 \mu \mathrm{eq} / \mathrm{g}$

Total anions $(\mu \mathrm{eq} / \mathrm{g})=\left[\mathrm{NO}_{3}^{-}\right] / 62.0+\left[\mathrm{NO}_{2}^{-}\right] / 46.0+\left[\mathrm{PO}_{4}{ }^{3}\right] / 31.7+\left[\mathrm{SO}_{4}{ }^{2}\right] / 48.0=$

The charge balance obtained by dividing the sum of the positive charges by the sum of the negative charges was 0.933 .

In summary, the above calculations yield reasonable mass and charge balance values (close to 1.00 for charge balance and 100 percent for mass balance), indicating the analytical results are generally consistent. 
HNF-SD-WM-ER-369 Rev. 2

Table B3-1. Solids Cation Mass and Charge Data.

\begin{tabular}{|c|c|c|c|c|}
\hline 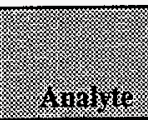 & 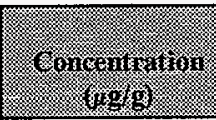 & 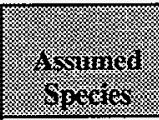 & 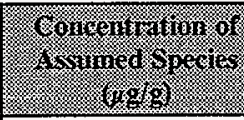 & 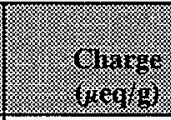 \\
\hline Aluminum & 63,300 & $\mathrm{Al}(\mathrm{OH})_{3}$ & 183,000 & 0 \\
\hline Bismuth & 8,130 & $\mathrm{BiPO}_{4}$ & 11,900 & 0 \\
\hline Iron & 22,900 & $\mathrm{FeO}(\mathrm{OH})$ & 36,400 & 0 \\
\hline Manganese & 9,820 & $\mathrm{MnO}_{2}$ & 15,500 & 0 \\
\hline Sodium & 63,900 & $\mathrm{Na}^{+}$ & 63,900 & 2,780 \\
\hline Silicon & 4,670 & $\mathrm{SiO}_{2}$ & 10,000 & 0 \\
\hline Uranium & 7,260 & $\mathrm{UO}_{2}^{2+}$ & 8,240 & 61.0 \\
\hline Total & & & 328,940 & 2,841 \\
\hline
\end{tabular}

Table B3-2. Solids Anion Mass and Charge Data.

\begin{tabular}{|c|c|c|c|c|}
\hline 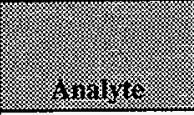 & 40 & 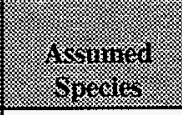 & ( & (3) \\
\hline Nitrate & 24,300 & $\mathrm{NO}_{3}^{-}$ & 24,300 & 1,176 \\
\hline Nitrite & 35,200 & $\mathrm{NO}_{2}^{-}$ & 35,200 & 1,530 \\
\hline Phosphate (ICP) & 4,510 & $\mathrm{PO}_{4}^{3-}$ & 4,510 & 142 \\
\hline Sulfate (IC) & 9,450 & $\mathrm{SO}_{4}^{2-}$ & 9,450 & 197 \\
\hline Total & & & 73,460 & 3,045 \\
\hline
\end{tabular}

Table B3-3. Solids Mass Balance Totals.

\begin{tabular}{|l|l|}
\hline & \\
\hline Total from Table B3-1 & 328,940 \\
\hline Total from Table B3-2 & 73,460 \\
\hline Weight percent water & 604,000 \\
\hline Grand total & $1,006,400$ \\
\hline
\end{tabular}


B3.3.2.2 Drainable Liquids. Except for sodium, all analytes were assumed to be present in their most common hydroxide, or oxide forms. Because precipitates are neutral species, all positive charge was attributed to the sodium cations.

The anions were assumed to be present as sodium salts and were expected to balance the positive charge exhibited by the cations. The concentrations of the cations listed in Table B3-4, the anions listed in Table B3-5, and the weight percent water results were ultimately used to calculate the mass balance. The mass balance can be calculated from the formula below. The factor 0.0001 is the conversion factor from $\mu \mathrm{g} / \mathrm{g}$ to weight percent.

$$
\begin{aligned}
\text { Mass balance }= & \% \text { Water }+0.0001 \times\{\text { Total Analyte Concentration }\} / \mathrm{SpG} \\
= & \% \text { Water }+0.0001 \times\left\{\left[\mathrm{Na}^{+}\right]+\left[\mathrm{NO}_{3}{ }^{-}\right]+\left[\mathrm{NO}_{2}{ }^{-}\right]+\left[\mathrm{PO}_{4}{ }^{3-}\right]+\right. \\
& {\left.\left[\mathrm{SO}_{4}{ }^{2-}\right]\right\} / 1.18 }
\end{aligned}
$$

The total analyte concentration calculated from the above equation was $174,915 \mu \mathrm{g} / \mathrm{g}$. The mean weight percent water was 76.6 percent, as determined by TGA. The mass balance resulting from adding the weight percent water to the total analyte concentration was 94.0 percent, as shown in Table B3-6.

The charge balance is the ratio of total cations $(\mu \mathrm{eq} / \mathrm{mL})$ to total anions $(\mu \mathrm{eq} / \mathrm{mL})$.

Total cations $(\mu \mathrm{eg} / \mathrm{mL})=\left[\mathrm{Na}^{+}\right] / 23.0=+4,100$

$\begin{aligned} \text { Total anions }(\mu \mathrm{eq} / \mathrm{mL}) & =\left[\mathrm{NO}_{3}\right] / 62.0+\left[\mathrm{NO}_{2}\right] / 46.0+\left[\mathrm{PO}_{4}{ }^{3}\right] / 31.7+\left[\mathrm{SO}_{4}{ }^{2}\right] / 48.0= \\ & -2,264\end{aligned}$

The charge balance yields a positive net charge of $1,836 \mu \mathrm{eq} / \mathrm{mL}$ that is not accounted for by the analytical data. Assuming all the charge imbalance is caused by hydroxide, which was not analyzed, the concentration of hydroxide would be $31,200 \mu \mathrm{g} / \mathrm{mL}$, and the total mass balance for the sample would be 97.1 percent.

In summary, the above calculations yield reasonable mass and charge balance values (close to 1.00 for charge balance and 100 percent for mass balance [assuming the net positive charge balance is caused by the absence of hydroxide]), indicating that the analytical results are generally consistent. 
HNF-SD-WM-ER-369 Rev. 2

Table B3-4. Liquid Cations Mass and Charge Data.

\begin{tabular}{|c|c|c|c|c|}
\hline (2) & 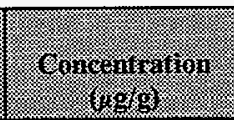 & (Inimed & 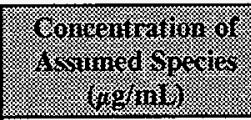 & 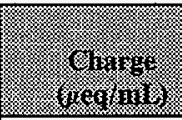 \\
\hline Sodium & 94,400 & $\mathrm{Na}^{+}$ & 94,400 & 4,100 \\
\hline Total & & & 94,400 & 4,100 \\
\hline
\end{tabular}

Table B3-5. Liquid Anions Mass and Charge Data.

\begin{tabular}{|c|c|c|c|c|}
\hline (: & 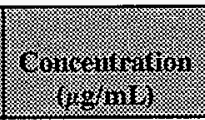 & $\begin{array}{l}\text { insinind } \\
\text { Speries }\end{array}$ & 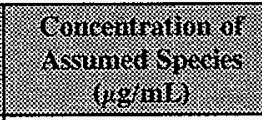 & (.). \\
\hline Nitrate & 37,100 & $\mathrm{NO}_{3}^{-}$ & 37,100 & $-598 \quad$. \\
\hline Nitrite & 54,200 & $\mathrm{NO}_{2}^{-}$ & 54,200 & $-1,180$ \\
\hline Phosphate (ICP) & 4,995 & $\mathrm{PO}_{4}{ }^{3-}$ & 4,995 & -158 \\
\hline Sulfate $(\mathrm{IC})$ & 15,720 & $\mathrm{SO}_{4}^{2-}$ & 15,720 & -328 \\
\hline Total & & & 112,000 & $-2,264$ \\
\hline
\end{tabular}

Table B3-6. Liquids Mass Balance Totals.

\begin{tabular}{|l|l|}
\hline & \\
\hline Total from Table B3-4 & $94,400 / 1.18$ \\
\hline Total from Table B3-5 & $112,000 / 1.18$ \\
\hline Weight percent water & 766,000 \\
\hline Grand total & 940,600 \\
\hline
\end{tabular}




\section{B3.4 MEANS AND CONFIDENCE INTERVALS}

\section{B3.4.1 Solid Data}

A nested analysis of variance model was fit to the 1997 and 1993 core segment data. Mean values and 95 percent confidence intervals on the mean were determined from the analysis of variance.

The composition of crystals observed in core 205, segment 2 samples was not included in estimating mean values for the solids. Four variance components were used in the calculations. The variance components represent concentration differences between risers, segments, laboratory samples, and analytical replicates. The model is:

$$
\begin{gathered}
Y_{i j k}=\mu+R_{i}+S_{i j}+L_{i j k}+A_{i j m m}, \\
I=1,2, \ldots, a ; j=1,2, \ldots, b_{i} ; k=1,2, \ldots, c_{i j} ; m=1,2, \ldots, n_{j j k}
\end{gathered}
$$

where

$$
\begin{aligned}
& Y_{i j \mathrm{~m}}=\text { concentration from the } \mathrm{m}^{\text {th }} \text { analytical result of the } \mathrm{k}^{\text {th }} \text { sample of the } j^{\text {th }} \\
& \text { segment of the } i^{\text {th }} \text { riser. } \\
& { }^{\prime} \mu=\text { the mean } \\
& R_{i} \quad=\text { the effect of the } i^{\text {th }} \text { riser } \\
& \mathrm{Sij}=\text { the effect of the } \mathrm{j}^{\text {th }} \text { segment from the } \mathrm{i}^{\text {th }} \text { riser } \\
& L_{\text {jik }}=\text { the effect of the } k^{\text {th }} \text { sample from the } j^{\text {th }} \text { segment of the } i^{\text {th }} \text { riser } \\
& \mathrm{A}_{\mathrm{j} \mathrm{jm}}=\text { the analytical error } \\
& \text { a }=\text { the number of risers } \\
& b_{i}=\text { the number of segments from the } i^{\text {th }} \text { riser } \\
& c_{i j}=\text { the number of samples from the } j^{\text {th }} \text { segment of the } i^{\text {th }} \text { riser } \\
& \mathrm{n}_{\mathrm{jik}}=\text { the number of analytical results from the } \mathrm{ij} \mathrm{k}^{\text {th }} \text { sample. }
\end{aligned}
$$

The variables $R_{i}, S_{i j}$, and $I_{j i k}$ are random effects. These variables, as well as $A_{i j k m}$, are assumed to be uncorrelated and normally distributed with means zero and variances $\sigma^{2}(R)$, $\sigma^{2}(\mathrm{~S}), \sigma^{2}(\mathrm{~L})$ and $\sigma^{2}(\mathrm{~A})$, respectively. 
The restricted maximum likelihood method was used to estimate the mean concentration and standard deviation of the mean for all analytes that had 50 percent or more of their reported values greater than the detection limit. The mean value and standard deviation of the mean were used to calculate the 95 percent confidence intervals. Table B3-7 gives the mean, degrees of freedom, and confidence interval for each constituent.

Some analytes had results below the detection limit. In these cases, the value of the detection limit was used for nondetected results. For analytes with a majority of results below the detection limit, a simple average is all that is reported.

The lower and upper limits, LL(95 percent) and UL( 95 percent), of a two-sided 95 percent confidence interval on the mean were calculated using the following equation:

$$
\begin{aligned}
& \operatorname{LL}(95 \%)=\hat{\mu}-t_{(d f, 0.025)} \times \hat{\sigma}(\hat{\mu}), \\
& U L(95 \%)=\hat{\mu}+t_{(d \dot{f}, 0.025)} \times \hat{\sigma}(\hat{\mu}) .
\end{aligned}
$$

In this equation, $\hat{\mu}$ is the restricted maximum likelihood estimate of the mean concentration, $\hat{\sigma}(\hat{\mu})$ is the restricted maximum likelihood estimate of the standard deviation of the mean, and $t_{(d f, 0.029)}$ is the quantile from Student's $t$ distribution with $d f$ (degrees of freedom). The degrees of freedom equals the number of risers with data minus one. In cases where the lower limit of the confidence interval was negative, it is reported as zero.

Table B3-7. 95 Percent Two-Sided Confidence Interval for the Mean Concentration

\begin{tabular}{|c|c|c|c|c|c|c|}
\hline (r) & 4 & 檾济 & 111 & (1) & 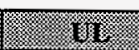 & (6) \\
\hline Aluminum & ICP:A & $6.33 \mathrm{E}+04$ & 3 & $0.00 \mathrm{E}+00$ & $1.82 E+05$ & $\mu \mathrm{g} / \mathrm{g}$ \\
\hline Antimony ${ }^{1}$ & ICP:A & $<1.07 \mathrm{E}+02$ & $\mathrm{n} / \mathrm{a}$ & $\mathrm{n} / \mathrm{a}$ & $\mathrm{n} / \mathrm{a}$ & $\mu \mathrm{g} / \mathrm{g}$ \\
\hline Arsenic $^{1}$ & ICP:A & $<8.52 \mathrm{E}+01$ & $\mathrm{n} / \mathrm{a}$ & $\mathrm{n} / \mathrm{a}$ & $\mathrm{n} / \mathrm{a}$ & $\mu \mathrm{g} / \mathrm{g}$ \\
\hline Barium $^{1}$ & ICP:A & $<7.59 \mathrm{E}+01$ & $\mathrm{n} / \mathrm{a}$ & $\mathrm{n} / \mathrm{a}$ & $\mathrm{n} / \mathrm{a}$ & $\mu \mathrm{g} / \mathrm{g}$ \\
\hline Beryllium ${ }^{1}$ & ICP:A & $<5.07 \mathrm{E}+00$ & $\mathrm{n} / \mathrm{a}$ & $n / a$ & $\mathrm{n} / \mathrm{a}$ & $\mu \mathrm{g} / \mathrm{g}$ \\
\hline Bismuth & ICP:A & $8.13 E+03$ & 3 & $0.00 \mathrm{E}+00$ & $2.88 \mathrm{E}+04$ & $\mu \mathrm{g} / \mathrm{g}$ \\
\hline Boron ${ }^{1}$ & ICP:A & $<4.95 \mathrm{E}+01$ & $\mathrm{n} / \mathrm{a}$ & $\mathrm{n} / \mathrm{a}$ & $\mathrm{n} / \mathrm{a}$ & $\mu \mathrm{g} / \mathrm{g}$ \\
\hline Bromide $^{1}$ & IC:W & $7.94 \mathrm{E}+02$ & 1 & $0.00 \mathrm{E}+00$ & $3.26 \mathrm{E}+03$ & $\mu \mathrm{g} / \mathrm{g}$ \\
\hline Cadmium $^{1}$ & ICP:A & $1.04 \mathrm{E}+01$ & 3 & $1.15 \mathrm{E}+00$ & $1.96 \mathrm{E}+01$ & $\mu \mathrm{g} / \mathrm{g}$ \\
\hline Calcium & ICP:A & $9.80 E+02$ & 3 & $3.42 \mathrm{E}+02$ & $1.62 E+03$ & $\mu \mathrm{g} / \mathrm{g}$ \\
\hline Cerium $^{1}$ & ICP:A & $<9.21 \mathrm{E}+01$ & $n / a$ & $\mathrm{n} / \mathrm{a}$ & $\mathrm{n} / \mathrm{a}$ & $\mu \mathrm{g} / \mathrm{g}$ \\
\hline Chloride & $\mathrm{IC}: \mathrm{W}$ & $4.09 \mathrm{E}+02$ & 3 & $2.83 \mathrm{E}+02$ & $5.36 \mathrm{E}+02$ & $\mu \mathrm{g} / \mathrm{g}$ \\
\hline Chromium & ICP:A & $8.65 \mathrm{E}+02$ & 3 & $0.00 \mathrm{E}+00$ & $1.81 \mathrm{E}+03$ & $\mu \mathrm{g} / \mathrm{g}$ \\
\hline Cobalt ${ }^{1}$ & ICP:A & $<2.87 \mathrm{E}+01$ & $n / a$ & $n / a$ & $\mathrm{n} / \mathrm{a}$ & $\mu \mathrm{g} / \mathrm{g}$ \\
\hline
\end{tabular}
for Solid Segment Data. (2 sheets) 
Table B3-7. 95 Percent Two-Sided Confidence Interval for the Mean Concentration for Solid Segment Data. (2 sheets)

\begin{tabular}{|c|c|c|c|c|c|c|}
\hline 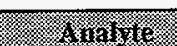 & Metion & (1) & 818 & (1) & 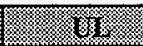 & $\log$ \\
\hline Copper ${ }^{1}$ & ICP:A & $1.82 \mathrm{E}+02$ & 1 & $0.00 \mathrm{E}+00$ & $1.92 \mathrm{E}+03$ & $\mu \mathrm{g} / \mathrm{g}$ \\
\hline Fluoride & IC:W & $4.73 E+02$ & 1 & $1.86 \mathrm{E}+01$ & $9.28 \mathrm{E}+02$ & $\mu \mathrm{g} / \mathrm{g}$ \\
\hline Gross alpha & ALPHA:F & $3.05 \mathrm{E}-01$ & 3 & $1.60 \mathrm{E}-01$ & $8.50 \mathrm{E}-01$ & $\mu \mathrm{g} / \mathrm{g}$ \\
\hline Iron & ICP:A & $2.29 \mathrm{E}+04$ & 3 & $6.38 \mathrm{E}+02$ & $4.51 \mathrm{E}+04$ & $\mu \mathrm{g} / \mathrm{g}$ \\
\hline Lanthanum $^{2}$ & ICP:A & $<4.49 \mathrm{E}+01$ & $\mathrm{n} / \mathrm{a}$ & $\mathrm{n} / \mathrm{a}$ & $\mathrm{n} / \mathrm{a}$ & $\mu \mathrm{g} / \mathrm{g}$ \\
\hline Lead & $\mathrm{ICP}: \mathrm{A}$ & $5.69 \mathrm{E}+02$ & 3 & $1.96 \mathrm{E}+02$ & $9.42 \mathrm{E}+02$ & $\mu \mathrm{g} / \mathrm{g}$ \\
\hline Lithium $^{1}$ & ICP:A & $4.18 \mathrm{E}+01$ & 3 & $0.00 \mathrm{E}+00$ & $1.10 \mathrm{E}+02$ & $\mu \mathrm{g} / \mathrm{g}$ \\
\hline Magnesium & ICP:A & $8.99 \mathrm{E}+02$ & 3 & $4.05 \mathrm{E}+02$ & $1.39 \mathrm{E}+03$ & $\mu \mathrm{g} / \mathrm{g}$ \\
\hline Manganese & ICP:A & $9.82 \mathrm{E}+03$ & 3 & $0.00 \mathrm{E}+00$ & $2.12 \mathrm{E}+04$ & $\mu \mathrm{g} / \mathrm{g}$ \\
\hline Molybdenum $^{1}$ & ICP:A & $5.22 \mathrm{E}+01$ & 3 & $1.42 \mathrm{E}+01$ & $9.03 \mathrm{E}+01$ & $\mu \mathrm{g} / \mathrm{g}$ \\
\hline Neodymium $^{2}$ & ICP:A & $<1.14 \mathrm{E}+02$ & $n / a$ & $\mathrm{n} / \mathrm{a}$ & $\mathrm{n} / \mathrm{a}$ & $\mu \mathrm{g} / \mathrm{g}$ \\
\hline Nickel & ICP:A & $9.11 \mathrm{E}+01$ & 3 & $3.88 \mathrm{E}+01$ & $1.43 \mathrm{E}+02$ & $\mu \mathrm{g} / \mathrm{g}$ \\
\hline Nitrate & IC:W & $2.29 \mathrm{E}+04$ & 3 & $1.51 \mathrm{E}+04$ & $3.07 \mathrm{E}+04$ & $\mu \mathrm{g} / \mathrm{g}$ \\
\hline Nitrite & IC:W & $3.28 \mathrm{E}+04$ & 3 & $2.14 \mathrm{E}+04$ & $4.42 \mathrm{E}+04$ & $\mu \mathrm{g} / \mathrm{g}$ \\
\hline Oxalate $^{1}$ & IC:W & $<1.58 \mathrm{E}+03$ & $\mathrm{n} / \mathrm{a}$ & $\mathrm{n} / \mathrm{a}$ & $n / a$ & $\mu \mathrm{g} / \mathrm{g}$ \\
\hline Phosphate & IC:W & $2.84 \mathrm{E}+03$ & 3 & $1.45 \mathrm{E}+03$ & $4.23 \mathrm{E}+03$ & $\mu \mathrm{g} / \mathrm{g}$ \\
\hline Phosphorus & ICP:A & $1.47 \mathrm{E}+03$ & 3 & $1.03 \mathrm{E}+03$ & $1.90 \mathrm{E}+03$ & $\mu \mathrm{g} / \mathrm{g}$ \\
\hline Potassium $^{1}$ & ICP:A & $5.14 \mathrm{E}+02$ & 3 & $1.15 \mathrm{E}+02$ & $9.12 \mathrm{E}+02$ & $\mu \mathrm{g} / \mathrm{g}$ \\
\hline Samarium $^{1}$ & ICP:A & $<1.02 \mathrm{E}+02$ & $n / a$ & $\mathrm{n} / \mathrm{a}$ & $\mathrm{n} / \mathrm{a}$ & $\mu \mathrm{g} / \mathrm{g}$ \\
\hline Silicon & ICP:A & $4.67 \mathrm{E}+03$ & 3 & $0.00 \mathrm{E}+00$ & $1.17 \mathrm{E}+04$ & $\mu \mathrm{g} / \mathrm{g}$ \\
\hline Silver ${ }^{1}$ & ICP:A & $2.89 \mathrm{E}+01$ & 3 & $2.59 \mathrm{E}+00$ & $5.53 \mathrm{E}+01$ & $\mu \mathrm{g} / \mathrm{g}$ \\
\hline Sodium & ICP:A & $6.39 \mathrm{E}+04$ & 3 & $4.13 \mathrm{E}+04$ & $8.65 \mathrm{E}+04$ & $\mu \mathrm{g} / \mathrm{g}$ \\
\hline Strontium & ICP:A & $1.75 \mathrm{E}+02$ & 3 & $1.04 \mathrm{E}+02$ & $2.46 \mathrm{E}+02$ & $\mu \mathrm{g} / \mathrm{g}$ \\
\hline Sulfate & IC:W & $9.45 \mathrm{E}+03$ & 3 & $6.63 \mathrm{E}+03$ & $1.23 \mathrm{E}+04$ & $\mu \mathrm{g} / \mathrm{g}$ \\
\hline Sulfur. & ICP:A & $2.88 \mathrm{E}+03$ & 3 & $1.78 \mathrm{E}+03$ & $3.97 \mathrm{E}+03$ & $\mu \mathrm{g} / \mathrm{g}$ \\
\hline Thallium $^{1}$ & ICP:A & $<2.02 \mathrm{E}+02$ & $n / a$ & $\mathrm{n} / \mathrm{a}$ & $\mathrm{n} / \mathrm{a}$ & $\mu \mathrm{g} / \mathrm{g}$ \\
\hline Titanium $^{1}$ & ICP:A & $4.58 \mathrm{E}+01$ & 3 & $1.55 \mathrm{E}+01$ & $7.60 \mathrm{E}+01$ & $\mu \mathrm{g} / \mathrm{g}$ \\
\hline Uranium $^{1}$ & ICP:A & $7.26 \mathrm{E}+03$ & 1 & $0.00 \mathrm{E}+00$ & $6.11 \mathrm{E}+04$ & $\mu \mathrm{g} / \mathrm{g}$ \\
\hline Vanadium $^{1}$ & ICP:A & $<7.18 \mathrm{E}+01$ & $\mathrm{n} / \mathrm{a}$ & $\mathrm{n} / \mathrm{a}$ & $\mathrm{n} / \mathrm{a}$ & $\mu \mathrm{g} / \mathrm{g}$ \\
\hline Zinc & ICP:A & $3.03 \mathrm{E}+02$ & 1 & $0.00 \mathrm{E}+00$ & $2.12 \mathrm{E}+03$ & $\mu \mathrm{g} / \mathrm{g}$ \\
\hline Zirconium ${ }^{1}$ & ICP:A & $5.59 \mathrm{E}+01$ & 3 & $2.08 \mathrm{E}+01$ & $9.10 \mathrm{E}+01$ & $\mu \mathrm{g} / \mathrm{g}$ \\
\hline
\end{tabular}
Note:

'A "less than" value was used in the calculations. 


\section{B3.4.2 Liquid Data}

A nested analysis of variance model was fit to the 1997 core sample liquid data. The 1993 data were not included in this analysis because core 54 drainable liquids were believed to be mostly hydrostatic head fluid (Silvers and Sasaki 1993) and were not analyzed; little drainable liquid was recovered in core 53 samples. Table B3-8 gives the mean, degrees of freedom, and confidence interval for each constituent.

Three variance components were used in the calculations. The variance components represent concentration differences between risers, laboratory samples, and analytical replicates. The model is:

$$
\begin{gathered}
Y_{i j k}=\mu+R_{i}+I_{i j}+A_{i j k}, \\
I=1,2, \ldots, a ; j=1,2, \ldots, b_{i} ; m=1,2, \ldots, n_{i j} ;
\end{gathered}
$$

where

$$
\begin{aligned}
& \mathbf{Y}_{\mathrm{ijk}}=\text { concentration from the } \mathrm{k}^{\text {th }} \text { analytical result of the } \mathrm{j}^{\text {th }} \text { sample of the } \mathrm{i}^{\text {th }} \text { riser } \\
& \mu \\
& \mathbf{R}_{i}=\text { the mean } \\
& \mathrm{L}_{\mathrm{ij}}=\text { the effect of the } \mathrm{i}^{\text {th }} \text { riser } \\
& \mathrm{A}_{\mathrm{ijk}}=\text { the effect of the } \mathrm{j}^{\text {th }} \text { sample from the } \mathrm{i}^{\text {th }} \text { riser } \\
& \mathrm{a}=\text { the number of risers } \\
& \mathrm{b}_{\mathrm{i}}=\text { the number of samples from the } \mathrm{i}^{\text {th }} \text { riser } \\
& \mathrm{n}_{\mathrm{ij}}=\text { the number of analytical results from the } \mathrm{ij}^{\text {th }} \text { sample. }
\end{aligned}
$$

The variables $R_{i}$, and $L_{i j}$ are random effects. These variables, as well as $A_{i i x}$, are assumed to be uncorrelated and normally distributed with means zero and variances $\sigma^{2}(R), \sigma^{2}(L)$, and $\sigma^{2}(A)$, respectively. 
Table B3-8. 95 Percent Two-Sided Confidence Interval for the Mean Concentration for Liquid Data. (2 sheets)

\begin{tabular}{|c|c|c|c|c|c|c|}
\hline Aratur & MEHInd & 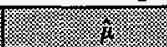 & 61 & 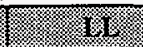 & US & Snits \\
\hline Aluminum & ICP & $3.62 \mathrm{E}+02$ & 1 & $0.00 \mathrm{E}+00$ & $1.69 \mathrm{E}+03$ & $\mu \mathrm{g} / \mathrm{mL}$ \\
\hline Antimony ${ }^{1}$ & ICP & $<2.41 \mathrm{E}+01$ & $\mathrm{n} / \mathrm{a}$ & $\mathrm{n} / \mathrm{a}$ & $\mathrm{n} / \mathrm{a}$ & $\mu \mathrm{g} / \mathrm{mL}$ \\
\hline Arsenic $^{1}$ & ICP & $<4.01 \mathrm{E}+01$ & $n / a$ & $n / a$ & $n / a$ & $\mu \mathrm{g} / \mathrm{mL}$ \\
\hline Barium $^{1}$ & $\mathrm{ICP}$ & $<2.01 \mathrm{E}+01$ & $n / a$ & $\mathrm{n} / \mathrm{a}$ & $n / a$ & $\mu \mathrm{g} / \mathrm{mL}$ \\
\hline Beryllium ${ }^{1}$ & ICP & $<2.00 \mathrm{E}+00$ & $\mathbf{n} / \mathbf{a}$ & $\mathrm{n} / \mathrm{a}$ & $\mathrm{n} / \mathrm{a}$ & $\mu \mathrm{g} / \mathrm{mL}$ \\
\hline Bismuth $^{1}$ & ICP & $<4.01 \mathrm{E}+01$ & $n / a$ & $n / a$ & $\mathrm{n} / \mathrm{a}$ & $\mu \mathrm{g} / \mathrm{mL}$ \\
\hline Boron ${ }^{1}$ & ICP & $<2.01 \mathrm{E}+01$ & $n / a$ & $\mathrm{n} / \mathrm{a}$ & $\mathrm{n} / \mathrm{a}$ & $\mu \mathrm{g} / \mathrm{mL}$ \\
\hline Bromide $^{1}$ & IC & $<1.11 E+03$ & $\mathrm{n} / \mathrm{a}$ & $n / a$ & $n / a$ & $\mu \mathrm{g} / \mathrm{mL}$ \\
\hline Cadmium $^{1}$ & ICP & $<2.14 \mathrm{E}+00$ & $\mathrm{n} / \mathrm{a}$ & $n / a$ & $\mathrm{n} / \mathrm{a}$ & $\mu \mathrm{g} / \mathrm{mL}$ \\
\hline Calcium & ICP & $7.32 \mathrm{E}+01$ & 1 & $2.22 \mathrm{E}+00$ & $1.44 \mathrm{E}+02$ & $\mu \mathrm{g} / \mathrm{mL}$ \\
\hline Cerium $^{1}$ & ICP & $<4.01 \mathrm{E}+01$ & $n / a$ & $\mathrm{n} / \mathrm{a}$ & $\mathrm{n} / \mathrm{a}$ & $\mu \mathrm{g} / \mathrm{mL}$ \\
\hline Chloride & IC & $4.61 \mathrm{E}+02$ & 1 & $0.00 \mathrm{E}+\infty 0$ & $2.08 \mathrm{E}+03$ & $\mu \mathrm{g} / \mathrm{mL}$ \\
\hline Chromium & $\longdiv { \mathrm { ICP } }$ & $2.03 \mathrm{E}+02$ & 1 & $0.00 \mathrm{E}+00$ & $8.32 \mathrm{E}+02$ & $\mu \mathrm{g} / \mathrm{mL}$ \\
\hline Cobalt $^{1}$ & ICP & $<8.02 \mathrm{E}+00$ & $\mathrm{n} / \mathrm{a}$ & $\mathrm{n} / \mathrm{a}$ & $n / a$ & $\mu \mathrm{g} / \mathrm{mL}$ \\
\hline Copper ${ }^{1}$ & ICP & $<5.11 \mathrm{E}+00$ & $\mathrm{n} / \mathrm{a}$ & $\mathrm{n} / \mathrm{a}$ & $\mathrm{n} / \mathrm{a}$ & $\mu \mathrm{g} / \mathrm{mL}$ \\
\hline Fluoride & IC & $6.28 \mathrm{E}+02$ & 1. & $5.15 \mathrm{E}+02$ & $7.40 \mathrm{E}+02$ & $\mu \mathrm{g} / \mathrm{mL}$ \\
\hline Iron $^{1}$ & $\mathrm{ICP}$ & $<2.01 \mathrm{E}+01$ & $\mathrm{n} / \mathrm{a}$ & $\mathrm{n} / \mathrm{a}$ & $\mathrm{n} / \mathrm{a}$ & $\mu \mathrm{g} / \mathrm{mL}$ \\
\hline Lanthanum ${ }^{1}$ & ICP & $<2.01 \mathrm{E}+01$ & $n / a$ & $\mathrm{n} / \mathrm{a}$ & $\mathrm{n} / \mathrm{a}$ & $\mu \mathrm{g} / \mathrm{mL}$ \\
\hline Lead $^{1}$ & ICP & $<4.01 \mathrm{E}+01$ & $\mathrm{n} / \mathrm{a}$ & $n / a$ & $\mathrm{n} / \mathrm{a}$ & $\mu \mathrm{g} / \mathrm{mL}$ \\
\hline Lithium $^{2}$ & ICP & $<3.56 \mathrm{E}+01$ & $\mathrm{n} / \mathrm{a}$ & $\mathrm{n} / \mathrm{a}$ & $\mathrm{n} / \mathrm{a}$ & $\mu \mathrm{g} / \mathrm{mL}$ \\
\hline Magnesium $^{1}$ & ICP & $<4.01 \mathrm{E}+01$ & $\mathrm{n} / \mathrm{a}$ & $\mathrm{n} / \mathrm{a}$ & $\mathrm{n} / \mathrm{a}$ & $\mu \mathrm{g} / \mathrm{mL}$ \\
\hline Manganese $^{1}$ & ICP & $<4.01 \mathrm{E}+00$ & $\mathrm{n} / \mathrm{a}$ & $\mathrm{n} / \mathrm{a}$ & $\mathrm{n} / \mathrm{a}$ & $\mu \mathrm{g} / \mathrm{mL}$ \\
\hline Molybdenum & ICP & $7.57 \mathrm{E}+01$ & 1 & $5.57 \mathrm{E}+01$ & $9.57 \mathrm{E}+01$ & $\mu \mathrm{g} / \mathrm{mL}$ \\
\hline Neodymium $^{1}$ & ICP & $<4.01 \mathrm{E}+01$ & $\mathrm{n} / \mathrm{a}$ & $\mathrm{n} / \mathrm{a}$ & $\mathrm{n} / \mathrm{a}$ & $\mu \mathrm{g} / \mathrm{mL}$ \\
\hline Nickel & ICP & $3.13 E+01$ & 1 & $0.00 \mathrm{E}+00$ & $7.70 \mathrm{E}+01$ & $\mu \mathrm{g} / \mathrm{mL}$ \\
\hline Nitrate & IC & $3.71 \mathrm{E}+04$ & 1 & $2.54 \mathrm{E}+04$ & $4.88 \mathrm{E}+04$ & $\mu \mathrm{g} / \mathrm{mL}$ \\
\hline Nitrite & IC & $5.42 \mathrm{E}+04$ & 1 & $2.41 \mathrm{E}+04$ & $8.43 \mathrm{E}+04$ & $\mu \mathrm{g} / \mathrm{mL}$ \\
\hline Oxalate $^{1}$ & IC & $<1.13 \mathrm{E}+03$ & $\mathrm{n} / \mathrm{a}$ & $\mathrm{n} / \mathrm{a}$ & $\mathrm{n} / \mathrm{a}$ & $\mu \mathrm{g} / \mathrm{mL}$ \\
\hline Phosphate & IC & $4.56 \mathrm{E}+03$ & 1 & $0.00 \mathrm{E}+00$ & $1.24 \mathrm{E}+04$ & $\mu \mathrm{g} / \mathrm{mL}$ \\
\hline Phosphorus & ICP & $1.63 \mathrm{E}+03$ & 1 & $1.35 \mathrm{E}+02$ & $3.12 \mathrm{E}+03$ & $\mu \mathrm{g} / \mathrm{mL}$ \\
\hline Potassium & ICP & $5.44 \mathrm{E}+02$ & 1 & $3.86 \mathrm{E}+02$ & $7.01 \mathrm{E}+02$ & $\mu \mathrm{g} / \mathrm{mL}$ \\
\hline
\end{tabular}


Table B3-8. 95 Percent Two-Sided Confidence Interval for the Mean Concentration for Liquid Data. (2 sheets)

\begin{tabular}{|c|c|c|c|c|c|c|}
\hline sinalures & 1. & 8 & 8 & 1.2 & 16 & inis. \\
\hline Samarium $^{1}$ & ICP & $<4.01 E+01$ & $\mathrm{n} / \mathrm{a}$ & $n / a$ & $n / a$ & $\mu \mathrm{g} / \mathrm{mL}$ \\
\hline Selenium $^{1}$ & ICP & $<4.01 \mathrm{E}+01$ & $n / a$ & $n / a$ & $n / a$ & $\mu \mathrm{g} / \mathrm{mL}$ \\
\hline Silicon & ICP & $4.16 \mathrm{E}+01$ & 1 & $0.00 \mathrm{E}+00$ & $1.22 \mathrm{E}+02$ & $\mu \mathrm{g} / \mathrm{mL}$ \\
\hline Silver & ICP & $6.79 \mathrm{E}+00$ & 1 & $1.86 \mathrm{E}+00$ & $1.17 \mathrm{E}+01$ & $\mu \mathrm{g} / \mathrm{mL}$ \\
\hline Sodium & ICP & $9.44 \mathrm{E}+04$ & 1 & $6.85 \mathrm{E}+04$ & $1.20 \mathrm{E}+05$ & $\mu \mathrm{g} / \mathrm{mL}$ \\
\hline Strontium $^{1}$ & ICP & $<4.01 E+00$ & $n / a$ & $\mathrm{n} / \mathrm{a}$ & $\mathrm{n} / \mathrm{a}$ & $\mu \mathrm{g} / \mathrm{mL}$ \\
\hline Sulfate & IC & $1.57 \mathrm{E}+04$ & 1 & $0.00 \mathrm{E}+00$ & $3.29 \mathrm{E}+04$ & $\mu \mathrm{g} / \mathrm{mL}$ \\
\hline Sulfur & ICP & $5.44 \mathrm{E}+03$ & 1 & $3.54 \mathrm{E}+03$ & $7.34 \mathrm{E}+03$ & $\mu \mathrm{g} / \mathrm{mL}$ \\
\hline Thallium $^{1}$ & ICP & $<8.02 E+01$ & $n / a$ & $n / a$ & $\mathrm{n} / \mathrm{a}$ & $\mu \mathrm{g} / \mathrm{mL}$ \\
\hline Titanium $^{1}$ & ICP & $<4.01 \mathrm{E}+00$ & $n / a$ & $n / a$ & $\mathrm{n} / \mathrm{a}$ & $\mu \mathrm{g} / \mathrm{mL}$ \\
\hline Uranium $^{1}$ & ICP & $<2.00 \mathrm{E}+02$ & $\mathrm{n} / \mathrm{a}$ & $\mathrm{n} / \mathrm{a}$ & $\mathrm{n} / \mathrm{a}$ & $\mu \mathrm{g} / \mathrm{mL}$ \\
\hline Vanadium $^{1}$ & ICP & $<2.01 E+01$ & $n / a$ & $n / a$ & n/a & $\mu \mathrm{g} / \mathrm{mL}$ \\
\hline Zinc $^{1}$ & ICP & $<4.01 \mathrm{E}+\infty 0$ & $n / a$ & $n / a$ & $n / a$ & $\mu \mathrm{g} / \mathrm{mL}$ \\
\hline Zirconium $^{1}$ & ICP & $<4.01 \mathrm{E}+00$ & $\mathrm{n} / \mathrm{a}$ & $\mathrm{n} / \mathrm{a}$ & $\mathrm{n} / \mathrm{a}$ & $\mu \mathrm{g} / \mathrm{mL}$ \\
\hline
\end{tabular}

Note:

1 A "less than" vahio was used in the calculations.

\section{B4.0 APPENDIX B REFERENCES}

Bell, K. E., 1993, Tank Waste Remediation System Tank Waste Characterization Plan, WHC-SD-WM-PLN-047, Rev. 1, Westinghouse Hanford Company, Richland, Washington.

De Lorenzo, D. S., A. T. DiCenso, D. B. Hiller, K. W. Johnson, J. H. Rutherford, D. J. Smith, and B. C. Simpson, 1994, Tank Characterization Reference Guide, WHC-SD-WM-TI-648, Rev. 0H, Westinghouse Hanford Company, Richland, Washington.

Dukelow, G. T., J. W. Hunt, H. Babad, and J. E. Meacham, 1995, Tank Safety Screening Data Quality Objective, WHC-SD-WM-SP-004, Rev. 2, Westinghouse Hanford Company, Richland, Washington. 
Esch, R. A., 1997, Tank 241-T-105, Cores 205 and 207 Analytical Results for the Final Report, HNF-SD-WM-DP-265, Rev. 0, Waste Management Federal Services of Hanford, Inc. for Fluor Daniel Hanford, Inc., Richland, Washington.

Field, J. G., 1997, Tank 241-T-105 Push Mode Core Sampling and Analysis Plan, HNF-SD-WM-TSAP-134, Rev. 0C, Lockheed Martin Hanford Corp. for Fluor Daniel Hanford, Inc., Richland, Washington.

Giamberardini, K. K., 1993, 222-S Laboratories Single-Shell Tank Waste Characterization, Tank T-105 Core 57 Data Package, WHC-SD-WM-DP-040, Rev. 0, Westinghouse Hanford Company, Richland, Washington.

Godfrey, W. L., 1965, 242-T Evaporator Feed, (internal letter to S. J. Beard, September 24), General Electric Company, Richland, Washington.

Kocher, K. L., 1994, WHC 222-S and PNL Laboratories Single-Shell Tank Waste Characterization, Tank T-105 Cores 53 and 54 Data Packages (Narrative) and Validation Summaries, WHC-SD-WM-DP-047, Rev. 0B, Westinghouse Hanford Company, Richland, Washington.

Meacham, J. E., D. L. Banning, M. R. Allen, and L. D. Muhlestein, 1997, Data Quality Objective to Support Resolution of the Organic Solvent Safety Issue, HNF-SD-WM-DQO-026, Rev. 0, DE\&S Hanford, Inc. for Fluor Daniel Hanford, Inc., Richland, Washington.

Schreiber, R. D., 1997, Memorandum of Understanding for the Organic Complexant Safety Issue Data Requirements, HNF-SD-WM-RD-060, Rev. 0, Lockheed Martin Hanford Corp. for Fluor Daniel Hanford, Inc., Richland, Washington.

Silvers, K. L., and L. M. Sasaki, 1993, Letter of Instruction for Tank T-105 Analysis Priorities, (internal memorandum 7K220-93-022 to K. L. Kocher, April 20), Westinghouse Hanford Company, Richland, Washington.

Wheeler, R. E., 1974, Analysis of Tank Farm Samples - Sample: T-4927, 105-T, (letter to R. L. Walser, September 17), Atlantic Richfield Hanford Company, Richland, Washington. 
HNF-SD-WM-ER-369 Rev. 2

This page intentionally left blank. 
HNF-SD-WM-ER-369 Rev. 2

This page intentionally left blank. 


\section{APPENDIX C \\ STATISTICAL ANALYSIS FOR ISSUE RESOLUTION}

Appendix $\mathbf{C}$ documents the results of the analyses and statistical and numerical manipulations required by the DQOs applicable for tank $241-\mathrm{T}-105$. The analyses required for tank 241-T-105 are reported as follows:

- Section C1.0: Statistical analysis and numerical manipulations supporting the safety screening DQO (Dukelow et al. 1995)

- Section C2.0: Appendix C References.

\section{C1.0 STATISTICS FOR THE SAFETY SCREENING DATA QUALITY OBJECTIVE}

The safety screening DQO (Dukelow et al. 1995) defines decision limits in terms of one-sided 95 percent confidence intervals. The safety screening DQO limits are $41 \mu \mathrm{Ci} / \mathrm{g}$ for gross alpha and $480 \mathrm{~J} / \mathrm{g}$ for DSC.

Confidence intervals were calculated for the mean values from each laboratory sample. The data used in the computations were from the data package of the 1997 core sampling event. Table C1-1 has the gross alpha results. There were no exothermic reactions in any 1997 DSC sample.

The upper limit (UL) of a one-sided 95 percent confidence interval on the mean is

$$
\hat{\mu}+t_{(d f, 0.05)} \hat{\sigma}_{\hat{\mu}} \text {. }
$$

In this equation, $\hat{\mu}$ is the arithmetic mean of the data, $\hat{\sigma}_{\hat{\mu}}$ is the estimate of the standard deviation of the mean, and $t_{(d f, 0.05)}$ is the quantile from Student's $t$ distribution with $d f$ (degrees of freedom). The degrees of freedom equals the number of samples minus one.

For sample numbers with at least one value above the detection limit, the upper limit of a 95 percent confidence interval is given in Table C1-1. Each confidence interval can be used to make the following statement. If the upper limit is less than $41 \mu \mathrm{Ci} / \mathrm{g}(61.5 \mu \mathrm{Ci} / \mathrm{mL}$ for drainable liquid), reject the null hypothesis that the alpha is greater than or equal to $41 \mu \mathrm{Ci} / \mathrm{g}$ ( $61.5 \mu \mathrm{Ci} / \mathrm{mL}$ for drainable liquid) at the 0.05 level of significance. 
Twenty-one of 26 gross alpha results were above the detection limit. The UL closest to the threshold was $8.23 \mathrm{E}-01 \mu \mathrm{Ci} / \mathrm{g}$, for core 53 , segment 1 . This is well below the limit of $41 \mu \mathrm{Ci} / \mathrm{g}$.

Table C1-1. 95 Percent Upper Confidence Limits for Gross Alpha.

\begin{tabular}{|l|l|l|l|l|l|}
\hline 19-5725 & Core 53 segment 2 & $2.76 \mathrm{E}-02$ & 1 & $3.35 \mathrm{E}-02$ & $\mu \mathrm{Ci} / \mathrm{mL}$ \\
\hline $25-6725$ & Core 53 segment 1 & $8.19 \mathrm{E}-01$ & 1 & $8.44 \mathrm{E}-01$ & $\mu \mathrm{Ci} / \mathrm{g}$ \\
\hline $25-7725$ & Core 53 segment 1 & $5.39 \mathrm{E}-03$ & 1 & $6.65 \mathrm{E}-03$ & $\mu \mathrm{Ci} / \mathrm{g}$ \\
\hline $33-6725$ & Core 54 segment 1 & $4.74 \mathrm{E}-01$ & 1 & $5.41 \mathrm{E}-01$ & $\mu \mathrm{Ci} / \mathrm{g}$ \\
\hline $33-7725$ & Core 54 segment 1 & $3.42 \mathrm{E}-03$ & 1 & $3.64 \mathrm{E}-03$ & $\mu \mathrm{Ci} / \mathrm{g}$ \\
\hline S97T001675 & Core 205, segment 1 & $3.20 \mathrm{E}-03$ & 1 & $8.59 \mathrm{E}-03$ & $\mu \mathrm{Ci} / \mathrm{mL}$ \\
\hline S97T001681 & Core 205, segment 2 & $1.42 \mathrm{E}-03$ & 1 & $2.02 \mathrm{E}-03$ & $\mu \mathrm{Ci} / \mathrm{mL}$ \\
\hline S97T001686F & Core 205, segment 2, lower half & $5.46 \mathrm{E}-01$ & 1 & $5.90 \mathrm{E}-01$ & $\mu \mathrm{Ci} / \mathrm{g}$ \\
\hline S97T001698F & Core 207, segment 1, lower half & $2.88 \mathrm{E}-01$ & 1 & $4.08 \mathrm{E}-01$ & $\mu \mathrm{Ci} / \mathrm{g}$ \\
\hline S97T001704F & Core 207, segment 2, lower half & $1.46 \mathrm{E}-01$ & 1 & $1.78 \mathrm{E}-01$ & $\mu \mathrm{Ci} / \mathrm{g}$ \\
\hline S97T001711F & Core 207, segment 2, upper half & $5.76 \mathrm{E}-01$ & 1 & $6.43 \mathrm{E}-01$ & $\mu \mathrm{Ci} / \mathrm{g}$ \\
\hline
\end{tabular}

Note:

${ }^{1}$ A "less than" value was used in the calculation.

\section{C2.0 APPENDIX C REFERENCES}

Dukelow, G. T., J. W. Hunt, H. Babad, and J. E. Meacham, 1995, Tank Safety Screening Data Quality Objective, WHC-SD-WM-SP-004, Rev. 2, Westinghouse Hanford Company, Richland, Washington. 
HNF-SD-WM-ER-369 Rev. 2

APPENDIX D

EVALUATION TO ESTABLISH BEST-BASIS INVENTORY FOR SINGLE-SHELL TANK 241-T-105 
HNF-SD-WM-ER-369 Rev. 2

This page intentionally left blank. 


\section{APPENDIX D \\ EVALUATION TO ESTABLISH BEST-BASIS INVENTORY FOR SINGLE-SBELL TANK 241-T-105}

An effort is underway to provide waste inventory estimates that will serve as standard characterization source terms for various waste management activities (Hodgson and LeClair 1996). As part of this effort, an evaluation of available information for single-shell tank 241-T-105 was performed, and a best-basis inventory was established. This work, detailed in the following sections, follows the methodology that was established by the standard inventory task.

\section{D1.0 CHEMICAL INFORMATION SOURCES}

As part of this effort, an evaluation was made of available chemical information for tank 241-T-105, including the following:

- Analytical results from cores 53 and 54 samples obtained in 1993 and cores 205 and 207 samples obtained in 1997 (see Appendix B)

- Analytical data from tanks containing bismuth phosphate process first decontamination cycle waste (1C1)

- Analytical data from tanks which contain REDOX high-level waste and REDOX cladding waste

- The HDW model document (Agnew et al. 1997a) which provides tank content estimates in terms of component concentrations and inventories.

\section{D2.0 COMPARISON OF COMPONENT INVENTORY VALUES}

Previous best-basis inventories and HDW model inventories are compared in Tables D2-1 and D2-2. The chemical species are reported without charge designation according to the best-basis inventory convention. The tank volume used to generate these inventories is $371 \mathrm{~kL}$ (98 kgal). This volume is reported in Hanlon (1998) and Agnew et al. (1997a). The density used to calculate the previous best-basis inventory was $1.64 \mathrm{~g} / \mathrm{mL}$, based on 1993 sample measurements. This density is higher than the 1.24 value reported in Agnew et al. 
The previous best-basis inventory was based in part on 1993 sample results. However, a significant difference was noted between sampling results and HDW model estimates for aluminum, bismuth, and manganese. This indicated the sample represents $\mathrm{CW}$ waste but probably does not represent the $2 \mathrm{C}$ waste type. As a result, the previous best-basis inventory . was derived by combining 1993 core sample results for tank 241-T-105 with analytical results for other tanks containing REDOX cladding waste and 2C waste types (LMHC 1998).

Table D2-1. Previous Best Basis and Historical Tank Content Inventory Estimates for Nonradioactive Components in Tank 241-T-105. (2 sheets).

\begin{tabular}{|c|c|c|}
\hline 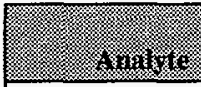 & 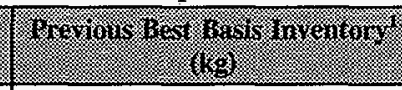 & 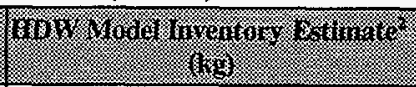 \\
\hline $\mathrm{Al}$ & 17,000 & 1,150 \\
\hline $\mathbf{B i}$ & 7,500 & 6,490 \\
\hline $\mathrm{Ca}$ & 2,200 & 1,860 \\
\hline $\mathrm{Cl}$ & 240 & 338 \\
\hline $\mathrm{CO}_{3}$ & 17,200 & 2,780 \\
\hline $\mathrm{Cr}$ & 360 & 72.0 \\
\hline$F$ & 1,200 & 1,160 \\
\hline $\mathrm{Fe}$ & 8,600 & 10,400 \\
\hline $\mathrm{Hg}$ & 1 & 1.85 \\
\hline $\mathbf{K}$ & 190 & 81.1 \\
\hline $\mathrm{La}$ & 0 & 0.00 \\
\hline $\mathrm{Mn}$ & 7,000 & 0.00 \\
\hline $\mathrm{Na}$ & 38,000 & 37,500 \\
\hline $\mathrm{Ni}$ & 28 & 27.1 \\
\hline $\mathrm{NO}_{2}$ & 4,000 & 1,630 \\
\hline $\mathrm{NO}_{3}$ & 31,000 & 22,000 \\
\hline $\mathrm{OH}$ & 42,500 & 13,800 \\
\hline $\mathrm{Pb}$ & 280 & 0.00 \\
\hline $\mathrm{PO}_{4}$ & 20,000 & 36,700 \\
\hline $\mathrm{Si}$ & 4,300 & 1,060 \\
\hline $\mathrm{SO}_{4}$ & 5,800 & 1,520 \\
\hline Sr & 85 & 0 \\
\hline TOC & 0 & 0 \\
\hline
\end{tabular}


Table D2-1. Previous Best Basis and Historical Tank Content Inventory Estimates for Nonradioactive Components in Tank 241-T-105. (2 sheets)

\begin{tabular}{|c|c|c|}
\hline & If h f & 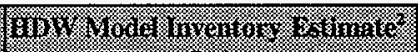 \\
\hline 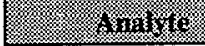 & (2) & (2) $(1,4)$ \\
\hline$U_{\text {total }}$ & 1,000 & 4,740 \\
\hline $\mathrm{Zr}_{\mathrm{r}}$ & 21 & 2.20 \\
\hline
\end{tabular}

Notes:

'Effective date, September 30, 1996 (LMHC 1998)

${ }^{2}$ Agnew et al. (1997a)

Table D2-2. Previous Best Basis and Historical Tank Content Inventory Estimates for Radioactive Components in Tank 241-T-105. ${ }^{1}$

\begin{tabular}{|c|c|c|}
\hline (2) & 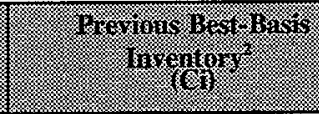 & 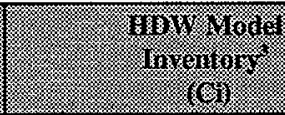 \\
\hline${ }^{241} \mathrm{Am}$ & 520 & 0.0372 \\
\hline${ }^{125} \mathrm{Sb}$ & 400 & 0.00399 \\
\hline${ }^{14} \mathrm{C}$ & 0.61 & 0.0169 \\
\hline${ }^{137} \mathrm{Cs}$ & 30,000 & 1,860 \\
\hline${ }^{60} \mathrm{Co}$ & 23 & 0.00413 \\
\hline${ }^{154} \mathrm{Eu}$ & 1,000 & 0.0763 \\
\hline${ }^{155} \mathrm{Eu}$ & 1,100 & 0.443 \\
\hline${ }^{239 / 240} \mathrm{Pu}$ & 84 & 26.6 \\
\hline${ }^{90} \mathrm{Sr}$ & $1.7 \mathrm{E}+05$ & 1,630 \\
\hline${ }^{99} \mathrm{Tc}$ & 230 & 0.117 \\
\hline${ }^{3} \mathrm{H}$ & 7.6 & 0.0811 \\
\hline
\end{tabular}

Notes:

'Curie vahues are decayed to January 1, 1994.

${ }^{2}$ Effective September 30, 1996 (LMHC 1998)

${ }^{3}$ Agnew et al. (1997a) 


\section{D3.0 COMPONENT INVENTORY EVALUATION}

The following evaluation of tank contents was performed to identify potential errors and/or missing information that would influence the sampling-based and HDW model component inventories.

\section{D3.1 WASTE HISTORY OF TANK 241-T-105}

Tank 241-T-105 is the middle tank in a cascade that includes tanks 241-T-104 and 241-T-106. In 1946, tank 241-T-105 began receiving 2C waste (Anderson 1990 and Agnew et al. 1997b). The waste was sent directly from $T$ Plant to tank 241-T-105, bypassing tank 241-T-104. The $2 \mathrm{C}$ waste cascaded from tank 241-T-105 to tank 241-T-106 when tank 241-T-105 was full.

In 1948, the cascade line from tank 241-T-104 to tank 241-T-105 was used to transfer $1 \mathrm{C}$ waste from tank 241-T-104. This 1C waste was combined with cladding waste from the removal of aluminum fuel element cladding. The cladding waste comprised about seven percent of the $1 \mathrm{C} / \mathrm{CW}$ waste stream. The cascade from tank 241-T-104 to tank 241-T-105 was used for transfer of $1 \mathrm{C} / \mathrm{CW}$ waste until the last additions of $1 \mathrm{C} / \mathrm{CW}$ waste from $\mathrm{T}$ Plant were made in 1954. In 1954, supernatant in tank 241-T-105 was transferred to cribs.

The tank began receiving CW at the beginning of 1955 , and it was full by the end of 1956 . This waste settled in the tank until 1967 when the supernatant was transferred to cribs. Agnew et al. (1997a) says that CW originated from the reduction oxidation (REDOX) process, but Anderson (1990) says the $\mathrm{CW}$ originated from the $\mathrm{BiPO}_{4}$ process. Waste transaction records in Agnew et al. (1997b) indicate $\mathrm{BiPO}_{4}$ was added rather than REDOX process aluminum cladding waste. However, the measurable difference between the two types of cladding waste is probably negligible.

In 1967, tank 241-T-105 was filled with dilute 300 Area laboratory waste. Much of the supernatant in tank 241-T-105 was sent to the 242-T Evaporator in 1967 and 1968.

Additional dilute wastes were sent to tank 241-T-105 from 1968 to 1973 . These waste types probably did not contribute significantly to the tank's solids volume. These wastes consisted of decontamination waste from $T$ Plant, some supernatant transferred from other single-shell tanks, B Plant low-level waste, and ion exchange waste. In 1974, most of the supernatant was transferred from tank 241-T-105.

Based on the process history, it is expected that $2 \mathrm{C}$ waste fills the tank bottom. The $1 \mathrm{C}$ waste makes up another layer. The records indicate that cladding waste may reside above the $1 \mathrm{C}$ waste. 


\section{D3.2 CONTRIBUTING WASTE TYPES}

The following waste types are predicted for tank 241-T-105.

\section{Expected Solids}

Anderson (1990), Hill et al. (1995): 1C, 2C, CW

Agnew et al. (1997a and 1997b): 1C, 2C

Model-Based Predicted Current Inventory (Agnew et al. 1997a)

Waste Type Waste Volume $\mathrm{kL}$ (kgal)

$1 \mathrm{C} 2$

$2 \mathrm{C} 2$

$98(26)$

$273(72)$

where

$\begin{array}{lll}1 \mathrm{C} & =\text { first decontamination cycle } \mathrm{BiPO}_{4} \text { waste } \\ 2 \mathrm{C} & =\text { second decontamination cycle } \mathrm{BiPO}_{4} \text { waste } \\ \mathrm{RCW} & =\mathrm{REDOX} \text { process aluminum cladding waste } \\ \mathrm{CW} & = & \mathrm{BiPO}_{4} \text { process aluminum cladding waste. }\end{array}$

The 1997 and 1993 analytical results for tank 241-T-105 indicate much higher concentrations of aluminum and lower concentrations of bismuth in the waste solids than would be predicted from waste that contained only $1 \mathrm{C}$ and $2 \mathrm{C}$ waste from the $\mathrm{BiPO}_{4}$ process. These results suggest a significant proportion of the waste that was sampled consists of $\mathrm{CW}$ which contains the precipitated aluminum resulting from neutralization of the dissolved aluminum fuel cladding. Agnew et al. (1997a) does not predict any $\mathrm{CW}$ beyond that mixed with the $1 \mathrm{C}$ waste in the tank.

The waste transaction record (Agnew et al. 1997b) shows that $980 \mathrm{~kL}$ (259 kgal) of CW was introduced into the tank during 1955 and 1956. Although the transaction records show that this waste was removed in 1967 , it is likely that a significant portion of the precipitated solids remained on the waste surface.

\section{D3.3 ASSUMPTIONS USED}

Because 1997 samples indicated the presence of REDOX cladding waste and $2 \mathrm{C}$ waste types, the sample means (where available) were used to compute the best-basis inventory for this tank. The samples showed the waste was highly heterogeneous both vertically and horizontally. Tank samples show a larger amount of liquids in the risers sampled, than predicted by Hanlon (1998) for the entire tank. Tank photos indicate the presence of liquids and floating solids in part of the tank, but also indicate that most of the surface has no liquid, and small area of the waste surface appears to be dry solids (Brevick et al. 1997). Because the 
tank is interim stabilized, it is assumed the sample results do not represent the total amount of free liquid in the tank, and Hanlon (1998) drainable liquid volumes are assumed to be present as free liquid.

The relative volumes of $\mathrm{CWR}$ and $1 \mathrm{C}$ or $2 \mathrm{C}$ waste were not apparent from the sample results. Therefore, it was assumed the sample solids results represent all three waste types. The HDW values were used for radionuclide inventory estimates when no sample results were available.

\section{D3.4 METHODOLOGY FOR ESTIMATING TANK 241-T-105 INVENTORY.}

\section{D3.4.1 Solids}

Table 3-1 compares average tank 241-T-105 solids analytical results (see Appendix B3.4) with average 1C and CWR sludge composition for other tanks (Kupfer et al. 1997), and compositions predicted by Agnew (1997a).

The table indicates the tank contains R/CWR waste, as evidenced by sample concentrations for aluminum, chromium, strontium and cesium which are significantly lower in $1 \mathrm{C}$ waste. The tank also clearly contains $1 \mathrm{C}$ waste, as evidenced by the high concentrations of bismuth, phosphate, and fluoride found in tank samples. These analytes are found at much lower concentrations in $\mathrm{R} / \mathrm{CWR}$ waste.

Table D3-1. Solids Composition for R1, CWR1, and 1C Waste Types, and Predictions for the Composition of Tank 241-T-105 Solids. (3 sheets)

\begin{tabular}{|c|c|c|c|c|c|c|}
\hline 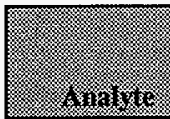 & 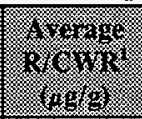 & 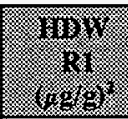 & $\frac{6}{63}$ & 20 & 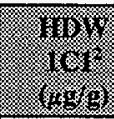 & 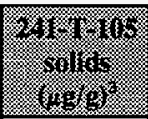 \\
\hline Al & 100,000 & 107,000 & 171,000 & 15,000 & 11,700 & 63,300 \\
\hline $\mathrm{Bi}$ & $<42.2$ & 0 & 0 & 16,700 & 9,440 & 8,130 \\
\hline $\mathrm{Ca}$ & 268 & 5,020 & 2,730 & 1,250 & 2,210 & 980 \\
\hline $\mathrm{CO}_{3}$ & 4,140 & 7,510 & 4,090 & 8,430 & 3,310 & $22,900^{5}$ \\
\hline $\mathrm{Cl}$ & 2,370 & 1,040 & 141 & 900 & 794 & 409 \\
\hline $\mathrm{Cr}$ & 1,920 & 1,830 & 59.8 & 795 & 183 & 865 \\
\hline $\mathbf{F}$ & $<120$ & 0 & 0 & 9,510 & 1,910 & 473 \\
\hline $\mathrm{Fe}$ & 1,613 & 32,200 & 5,200 & 14,300 & 14,250 & 22,900 \\
\hline $\mathrm{Hg}$ & $<0.126$ & NR & 462 & $<0.318$ & 15.4 & $23.9^{3}$ \\
\hline $\mathbf{K}$ & 432 & 250 & 33.9 & 270 & 190 & 514 \\
\hline
\end{tabular}


Table D3-1. Solids Composition for R1, CWR1, and 1C Waste Types, and Predictions for the Composition of Tank 241-T-105 Solids. (3 sheets)

\begin{tabular}{|c|c|c|c|c|c|c|}
\hline 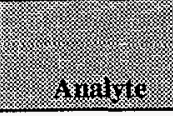 & for gor & a & (19) & $\left(\frac{6}{6}\right)$ & 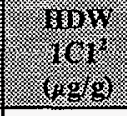 & 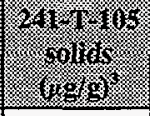 \\
\hline $\mathrm{La}$ & $<10.8$ & 0 & 0 & $<35$ & 0 & $<44.9$ \\
\hline Mn & 1,330 & 0 & 0 & 140 & 0 & 9,820 \\
\hline $\mathrm{Na}$ & 97,800 & 106,000 & 102,000 & 92,300 & 87,000 & 63,900 \\
\hline $\mathrm{Ni}$ & 118 & 1,690 & 33.7 & 68. & 51 & 91.1 \\
\hline $\mathrm{NO}_{2}$ & 30,433 & 38,200 & 24,900 & 12,600 & 7,860 & 32,800 \\
\hline $\mathrm{NO}_{3}$ & 122,500 & 187,000 & 20,000 & 91,100 & 46,500 & 22,900 \\
\hline $\mathrm{Pb}$ & 33.2 & 0 & 13,800 & 300 & 0 & 569 \\
\hline $\mathrm{PO}_{4}$ & $<1,730$ & 0 & 0 & 76,600 & 79,200 & 4,510 \\
\hline $\mathrm{Si}$ & 1,250 & 129 & 319 & 6,990 & 4,550 & 4,670 \\
\hline $\mathrm{SO}_{4}$ & 1,489 & 569 & 455 & 9,290 & 3,620 & 9,450 \\
\hline Sr & 420 & 0 & 0 & 298 & 0 & 175 \\
\hline TOC & 1,730 & 0 & 0 & 940 & 0 & $4,590^{5}$ \\
\hline $\mathrm{U}$ & 7,690 & 207 & 24,400 & 6,300 & 35,100 & 7,260 \\
\hline $\mathrm{Zr}$ & 66.9 & 0 & 0 & 113 & 16 & 55.9 \\
\hline \multicolumn{7}{|c|}{ 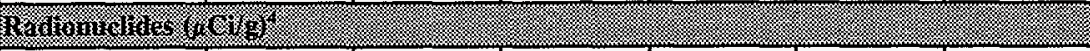 } \\
\hline Total alpha & NR & NR & NR & NR & NR & 0.505 \\
\hline${ }^{90} \mathrm{Sr}$ & 288 & 528.6 & 1.16 & 25.8 & 5.51 & $280^{5}$ \\
\hline${ }^{137} \mathrm{Cs}$ & 77.6 & 31.9 & 1.33 & 20.0 & 6.21 & $32.3^{5}$ \\
\hline${ }^{134} \mathrm{Cs}$ & NR & $1.55 \mathrm{E}-05$ & $9.34 \mathrm{E}-07$ & NR & 7.5E-08 & $<0.055^{5}$ \\
\hline${ }^{24 \mathrm{Am}} \mathrm{Am}$ & NR & 0.00461 & 0.000231 & NR & $2.2 \mathrm{E}-05$ & $0.242^{5}$ \\
\hline${ }^{125} \mathrm{Sb}$ & NR & 0.000747 & $4.46 \mathrm{E}-06$ & NR & $4.7 \mathrm{E}-06$ & $0.665^{5}$ \\
\hline${ }^{14} \mathrm{C}$ & NR & 0.00129 & $6.16 \mathrm{E}-06$ & NR & $6.3 \mathrm{E}-05$ & $0.001^{5}$ \\
\hline${ }^{60} \mathrm{Co}$ & NR & 0.000509 & $2.66 \mathrm{E}-05$ & NR & $8.7 \mathrm{E}-06$ & $0.038^{5}$ \\
\hline${ }^{154} \mathrm{Eu}$ & NR & 0.0123 & 0.000648 & NR & 0.00012 & $1.79^{5}$ \\
\hline${ }^{155} \mathrm{Eu}$ & NR & 0.188 & 0.00471 & $\mathrm{NR}$ & 0.00093 & $2.11^{5}$ \\
\hline${ }^{238} \mathrm{Pu}$ & NR & 0.00377 & 0.0142 & NR & $3.9 \mathrm{E}-05$ & $2.45 \mathrm{E}-04^{5}$ \\
\hline${ }^{239 / 240} \mathrm{Pu}$ & NR & NR & NR & NR & NR & $0.138^{5}$ \\
\hline${ }^{239} \mathrm{Pu}$ & $\mathrm{NR}$ & 0.269 & 0.908 & NR & 0.0122 & $\mathrm{NR}$ \\
\hline${ }^{240} \mathrm{Pu}$ & NR & 0.0385 & 0.128 & NR & 0.00072 & NR \\
\hline
\end{tabular}


Table D3-1. Solids Composition for R1, CWR1, and 1C Waste Types, and Predictions for the Composition of Tank 241-T-105 Solids. (3 sheets)

\begin{tabular}{|c|c|c|c|c|c|c|}
\hline$\frac{4}{4}$ & 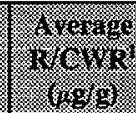 & 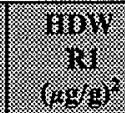 & 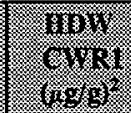 & $\int^{2}+2, y$ & $\frac{9189}{191}$ & 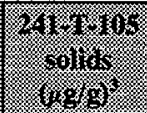 \\
\hline${ }^{99} \mathrm{Tc}$ & NR & 0.00902 & 0.000442 & NR & 0.00043 & $0.372^{5}$ \\
\hline${ }^{3} \mathrm{H}$ & NR & 0.0167 & 0.000571 & NR & 0.00025 & $0.012^{5}$ \\
\hline Density $(\mathrm{g} / \mathrm{mL})$ & 1.77 & 1.76 & 1.77 & 1.40 & 1.38 & 1.45 \\
\hline
\end{tabular}

Notes:

NR $=$ Not reported

${ }^{1}$ Average of analyte concentrations for selected tanks (Kupfer 1997)

${ }^{2}$ Agnew et al. (1997a)

'Average for 1993 and 1997 core samples (see Appendix B3.4)

"Radiomuclides are decayed to Jamuary 1, 1994.

SSample results were obtained for 1993 core samples only.

\section{D3.4.2 Liquids}

Table D3-2 compares tank 241-T-105 free liquid sample concentrations with supernatant composition estimates for 1C and CWR1 (Agnew et al 1997a). Because no supernatant is predicted in the tank, Agnew (1997a) does not predict a separate liquid composition for tank 241-T-105. The table indicates that the free liquid in the tank is a mixture of the CWR1 and $1 \mathrm{C} 1$ supernatant waste types.

Table D3-2. Liquid Composition for Tank 241-T-105. (2 sheets)

\begin{tabular}{|c|c|c|c|}
\hline 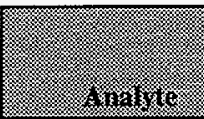 & 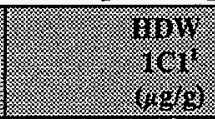 & ( & (1) \\
\hline $\mathrm{Al}$ & 0 & 26,300 & 362 \\
\hline $\mathrm{Bi}$ & 760 & 0 & $<40.1$ \\
\hline $\mathrm{Ca}$ & 328 & 296 & 73.2 \\
\hline $\mathrm{CO}_{3}$ & 22,100 & 443 & NR \\
\hline $\mathrm{Cl}$ & 1,390 & 315 & 461 \\
\hline $\mathrm{Cr}$ & 320 & 133 & 203 \\
\hline$F$ & 3,340 & 0 & 628 \\
\hline
\end{tabular}


Table D3-2. Liquid Composition for Tank 241-T-105. (2 sheets)

\begin{tabular}{|c|c|c|c|}
\hline$\left(\frac{1}{2}\right.$ & $\begin{array}{l}\text { waW } \\
\text { (1) }\end{array}$ & (3) & 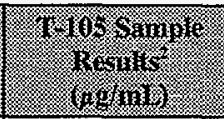 \\
\hline $\mathrm{Fe}$ & 102 & 91.5 & $<20.1$ \\
\hline $\mathrm{Hg}$ & 1.83 & 1.64 & NR \\
\hline $\mathbf{K}$ & 333 & 75.6 & 544 \\
\hline $\mathrm{La}$ & 0 & 0 & $<20.1$ \\
\hline Mn & 0 & 0 & $<4.01$ \\
\hline $\mathrm{Na}$ & 54,600 & 68,300 & 94,400 \\
\hline $\mathrm{Ni}$ & 88.9 & 75.2 & 31.3 \\
\hline $\mathrm{NO}_{2}$ & 9,280 & 55,000 & 54,200 \\
\hline $\mathrm{NO}_{3}$ & 87,300 & 45,300 & 37,100 \\
\hline $\mathrm{Pb}$ & 0. & 272 & $<40.1$ \\
\hline $\mathrm{PO}_{4}$ & 13,000 & 0 & 4,995 \\
\hline $\mathrm{Si}$ & 870 & 711 & 41.6 \\
\hline $\mathrm{SO}_{4}$ & 6,330 & 1,014 & 15,700 \\
\hline $\mathrm{Sr}$ & 0 & 0 & $<4.01$ \\
\hline TOC & 0 & 0 & NR \\
\hline $\mathbf{U}$ & 866 & 780 & $<200$ \\
\hline $\mathrm{Zr}$ & 27.6 & 0 & $<4.01$ \\
\hline \multicolumn{4}{|c|}{ 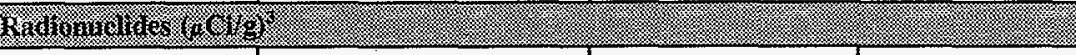 } \\
\hline Total alpha & $\mathrm{NR}$ & NR & $0.00265(\mu \mathrm{Ci} / \mathrm{mL})$ \\
\hline${ }^{90} \mathrm{Sr}$ & 9.64 & 2.58 & NR \\
\hline${ }^{137} \mathrm{Cs}$ & 10.9 & 2.96 & NR \\
\hline Specific gravity & 1.10 & 1.22 & 1.18 \\
\hline
\end{tabular}

Notes:

${ }^{1}$ Agnew et al. (1997a)

${ }^{2}$ Average for 1997 samples (see Appendix B3.4)

${ }^{3}$ Radionuclides decayed to January 1, 1994. 


\section{D3.5 ESTIMATED INVENTORY OF COMPONENTS}

Estimated sample-based inventories were calculated and compared with HDW model-based inventories in Table D3-3. The solids inventory for tank 241-T-105 in Table D3-3 was determined by multiplying sample concentrations by an average sample density of 1.45 and a volume of $284 \mathrm{~kL}$ ( $75 \mathrm{kgal}$ ) (total tank volume less free liquid volume). The best-basis liquid inventory for the tank was calculated by multiplying sample concentrations by a volume of $87 \mathrm{~kL}$ ( $23 \mathrm{kgal})$. Based on sample observations, this assumes the interstitial liquid predicted by Hanlon (1998) is present as free liquid in the tank.

Table D3-3. Estimated Inventory for Tank 241-T-105. (2 sheets)

\begin{tabular}{|c|c|c|c|c|}
\hline (2) & 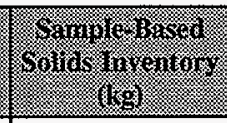 & 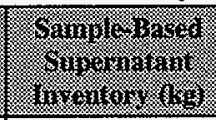 & 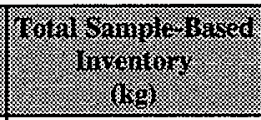 & 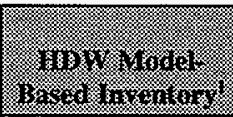 \\
\hline $\mathrm{Al}$ & 26,100 & 31.5 & 26,100 & 1,150 \\
\hline$\overline{\mathrm{Bi}}$ & 3,350 & 3.49 & 3,350 . & 6,490 \\
\hline $\mathrm{Ca}$ & 404 & 6.37 & 410 & 1,860 \\
\hline $\mathrm{CO}_{3}$ & 9,430 & NR & 9,430 & 2,780 \\
\hline $\mathrm{Cl}$. & 168 & 40.1 & 208 & 338 \\
\hline $\mathrm{Cr}$ & 356 & 17.7 & 374 & 72.0 \\
\hline $\mathbf{F}$ & 195 & 54.6 & 250 & 1,160 \\
\hline $\mathrm{Fe}$ & 9,430 & 1.75 & 9,430 & 10,400 \\
\hline $\mathrm{Hg}$ & 9.84 & NR & 9.84 & 1.85 \\
\hline $\mathrm{K}$ & 212 . & 47.3 & 259 & 81.1 \\
\hline $\mathrm{La}$ & 18.5 & 1.75 & 20.2 & 0 \\
\hline $\mathrm{Mn}$ & 4,040 & 0.35 & 4,040 & 0 \\
\hline $\mathrm{Na}$ & 26,300 & 8,210 & 34,500 & 37,500 \\
\hline $\mathrm{Ni}$ & 37.5 & 2.72 & 40.2 & 27.1 \\
\hline $\mathrm{NO}_{2}$ & 13,500 & 4,720 & 18,220 & 1,630 \\
\hline $\mathrm{NO}_{3}$ & 9,430 & 3,230 . & 12,700 & 22,000 \\
\hline $\mathrm{Pb}$ & 234 & 3.49 & 237 & 27.1 \\
\hline $\mathrm{PO}_{4}$ & 1,860 & 435. & 2,290 & 36,700 \\
\hline \begin{tabular}{|l|}
$\mathrm{Si}$ \\
\end{tabular} & 1,920 & 3.62 & 1,920 & 1,060 \\
\hline $\mathrm{SO}_{4}$ & 3,890 & 1,370 & 5,260 & 1,520 \\
\hline $\mathbf{S r}$ & 72.1 & 0.35 & 72.5 & 0 \\
\hline
\end{tabular}


Table D3-3. Estimated Inventory for Tank 241-T-105. (2 sheets)

\begin{tabular}{|c|c|c|c|c|}
\hline 妾 & 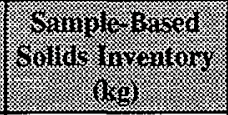 & 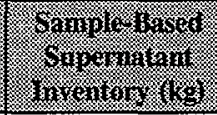 & Hat & 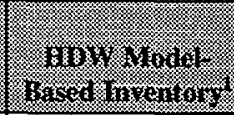 \\
\hline TOC & 1,890 & $\mathrm{NR}$ & 1,890 & 0 \\
\hline $\mathrm{U}$ & 2,990 & 17.4 & 3,010 & 9,980 \\
\hline $\mathrm{Zr}$ & 23.0 & 0.35 & 23.4 & 2.20 \\
\hline \multicolumn{5}{|c|}{ 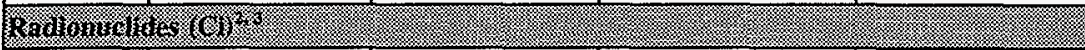 } \\
\hline${ }^{90} \mathrm{Sr}$ & 115,000 & 0 & 115,000 & 1,630 \\
\hline${ }^{137} \mathrm{Cs}$ & 13,300 & 0 & 13,300 & 1,860 \\
\hline${ }^{134} \mathrm{Cs}$ & 22.7 & 0 & 22.7 & 1.71E-04 \\
\hline${ }^{241} \mathrm{Am}$ & 99.7 . & 0 & 99.7 & 0.0372 \\
\hline${ }^{125} \mathrm{Sb}$ & 274 & 0 & 274 & 0.00399 \\
\hline${ }^{14} \mathrm{C}$ & 0.41 & 0 & 0.41 & 0.0169 \\
\hline${ }^{60} \mathrm{Co}$ & 15.7 & 0 & 15.7 & 0.00413 \\
\hline${ }^{154} \mathrm{Eu}$ & 737 & 0 & 737 & 0.0763 \\
\hline${ }^{155} \mathrm{Eu}$ & 869 & 0 & 869 & 0.443 \\
\hline${ }^{238} \mathrm{Pu}$ & 0.100 & 0 & 0.100 & 0.106 \\
\hline${ }^{239} \mathrm{Pu}$ & 54.8 & 0 & 54.8 & 24.9 \\
\hline${ }^{240} \mathrm{Pu}$ & 2.06 & 0 & 2.06 & 1.68 \\
\hline${ }^{99} \mathrm{Tc}$ & 153 & 0 & 153 & 0.117 \\
\hline${ }^{3} \mathbf{H}$ & 4.94 & 0 & 4.94 & 0.0811 \\
\hline
\end{tabular}

Notes:

'Agnew et al. (1997a)

${ }^{2}$ Radionuclide vahues decayed to Jamuary 1, 1994.

- 3Radionuclide samaple results were obtained for 1993 core samples only.

Observations regarding these inventories are noted, by component, in the following text.

Bismuth. The sample-based inventory for bismuth was about half the value of the HDW model inventory. The HDW model inventory values are high because no R/CWR waste is predicted in the model.

Chromium. This sample-based inventory for chromium was about five times higher than the HDW model-based inventory because the HDW model assumes there is no R/CWR waste in 
the tank and that no $\mathrm{Cr}$ precipitated in the $1 \mathrm{C}$ and $2 \mathrm{C}$ waste streams. Although $\mathrm{CWR}$ waste is expected to be low in $\mathrm{Cr}, \mathrm{R}$ waste is much higher comparatively.

Iron. Relatively good agreement was observed between the sample-based iron inventory and HDW model-based inventory. This is somewhat surprising because no iron is expected in the CWR waste type except from corrosion. Higher corrosion than expected is a possible explanation for the comparable analytical value.

Aluminum. The sample-based aluminum inventory was about 20 times greater than that predicted by the HDW model. This is attributed to the large amount of R/CWR waste which was not predicted by the HDW model.

Manganese. The HDW model predicts no manganese in tank 241-T-105. Records do not indicate additions of $\mathrm{Mn}$ as part of the flowsheet. However, significant quantities of $\mathrm{Mn}$ were detected in the sample. The source may be waste from decontamination of equipment at $\mathrm{T}$ Plant using $\mathrm{KMnO}_{4}$. Agnew et al. (1997b) shows that decontamination waste was added to tank 241-T-105 in 1968 and 1969.

Sodium. Relatively good agreement was observed between the sample-based sodium inventory and the HDW model-based inventory. Sodium is expected at similar concentrations in the $\mathrm{R} / \mathrm{CWR}$ waste and $1 \mathrm{C} / 2 \mathrm{C}$ waste.

Silicon. The sample-based silicon inventory compares well with the HDW model. This is somewhat surprising because the HDW model does not predict any CWR waste in the tank, which is expected to have significant lower concentrations of Si.

Fluoride. The sample-based fluoride inventory was significantly lower than the HDW modelbased inventory because the R/CWR waste types are expected to contain little or no fluoride.

Potassium. The sample-based inventory for potassium was about three times higher than the HDW model-based inventory. The HDW model shows $\mathrm{K}$ in the $1 \mathrm{C}$ defined waste. It is probably present as a contaminant from sodium hydroxide which was used to neutralize the acidic wastes. Analyses indicate the presence of $K$ which provides substantive evidence that $K$ entered the tank as a contaminant. In addition, Agnew et al. (1997b) indicates that K may have been added (as $\mathrm{KMnO}_{4}$ ) from decontamination activities at $\mathrm{T}$ Plant.

Nitrate/Nitrite. The sample-based nitrate inventory is approximately one half that predicted by the HDW model. However, the sample-based nitrite inventory is significantly higher than predicted by the HDW model. When combined, the total nitrate and nitrite analytical inventories are slightly higher than the HDW model-based inventories.

Phosphate. The sample-based phosphate inventory was approximately 16 times lower than the HDW model-based inventory. A large inventory was predicted by the HDW because of the 
high concentration of phosphate in the $1 \mathrm{C} / 2 \mathrm{C}$ waste types. Little or no phosphate is expected in the R or CWR waste types which were not predicted by HDW model.

Sulfate. The HDW model-based inventory estimate is about three times lower than the sample-based inventory for sulfate. This was surprising because $\mathrm{IC}$ and $2 \mathrm{C}$ waste is expected to contain higher concentrations of sulfate than R/CWR waste.

Hydroxide. Once the best-basis inventories were determined, the hydroxide inventory was calculated by performing a charge balance with the valence of other analytes. This charge balance approach is consistent with that used by Agnew et al. (1997a).

Strontium-90 and Cesium-137. The sample-based inventories for ${ }^{90} \mathrm{Sr}$ and ${ }^{137} \mathrm{Cs}$ were higher than HDW model-based inventories. This was expected because R/CWR waste (not predicted in the HDW model but considered present) contains much greater radioactivity than the $1 \mathrm{C} / 2 \mathrm{C}$ waste.

Alpha isotopes. Sample data for plutonium isotopes corresponded relatively well with HDW model calculations. However, ${ }^{241} \mathrm{Am}$ was detected at significantly higher levels than predicted by the HDW model, and the combined sample values for plutonium and americium isotopes are not consistent with the average total alpha sample values. Data indicates the presence of higher levels of ${ }^{241} \mathrm{Am}$ than are reported in the HDW model, but the sample data is not as consistent for plutonium isotopes. Consequentiy, best-basis values were determined assuming ${ }^{241} \mathrm{Am}$ values are correct and calculating plutonium isotope inventories based on total alpha ratioed to plutonium isotope values in the HDW model.

\section{D4.0 DEFINE THE BEST-BASIS AND ESTABLISH COMPONENT INVENTORIES}

Information about chemical, radiological, and/or physical properties is used to perform safety analyses, engineering evaluations, and risk assessments associated with waste management activities, as well as regulatory issues. These activities include overseeing tank farm operations and identifying, monitoring, and resolving safety issues associated with these operations and with the tank wastes. Disposal activities involve designing equipment, processes, and facilities for retrieving wastes and processing them into a form that is suitable for long-term storage/disposal.

Chemical and radiological inventory information are generally derived using three approaches: 1) component inventories are estimated using the results of sample analyses; 2) component inventories are predicted using the HDW model based on process knowledge and historical information; or 3) a tank-specific process estimate is made based on process flowsheets, reactor fuel data, essential material usage, and other operating data. 
An effort is underway to provide waste inventory estimates that will serve as the standard characterization for management activities (Hodgson and LeClair 1996). As part of this effort, an evaluation of available chemical information for tank 241-T-105 was performed including the following information:

- Data from core samples from tank 241-T-105 collected in 1997 and 1993

- Representative sample data for 1C and CW waste types (Kupfer et al.1997)

- An inventory estimate generated by the HDW model (Agnew et al. 1997a).

The evaluation supports using the sample-based results as the best-basis inventory for this tank. Where sample results were not available, engineering evaluations based on sample results for other tanks containing 1C and CW waste (Kupfer et al.1997) are used as the best basis. Where isotope-specific sample data is not available, the HDW model values, or a combination of sample results and HDW model values, are used to determine radionuclide inventories.

Best-basis tank inventory values are derived for 46 key radionuclides (as defined in Section 3.1 of Kupfer et al. 1997), all decayed to a common report date of January 1, 1994. Often, waste sample analyses have only reported ${ }^{90} \mathrm{Sr},{ }^{137} \mathrm{Cs}$, ${ }^{239 / 240} \mathrm{Pu}$, and total uranium (or total beta and total alpha), while other key radionuclides such as ${ }^{60} \mathrm{Co},{ }^{99} \mathrm{Tc},{ }^{129} \mathrm{~T},{ }^{154} \mathrm{Eu},{ }^{155} \mathrm{Eu}$, and ${ }^{241} \mathrm{Am}$, have been infrequently reported. For this reason, it has been necessary to derive most of the 46 key radionuclides by computer models. These models estimate radionuclide activity in batches of reactor fuel, account for the split of radionuclides to various separations plant waste streams, and track their movement with tank waste transactions. These computer models are described in Kupfer et al. 1997, Section 6.1, and in Watrous and Wootan 1997. Model generated values for radionuclides in any of 177 tanks are reported in Agnew et al. $1997 \mathrm{~b}$. The best-basis value for any one analyte may be either a model result or a sample or engineering assessment-based result, if available.

Tables D4-1 and D4-2 show the best-basis inventory estimate for tank 241-T-105. Mercury values were specified in Simpson (1998). Radionuclide curie values are decayed to January 1, 1994.

The inventory values reported in Tables D4-1 and D4-2 are subject to change. Refer to the Tank Characterization Database (LMHC 1998) for the most current inventory values. 


\section{HNF-SD-WM-ER-369 Rev. 2}

Table D4-1. Best-Basis Inventory Estimates for Nonradioactive Components in Tank 241-T-105 (Effective April 1, 1998).

\begin{tabular}{|c|c|c|c|}
\hline (3) & I & 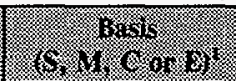 & 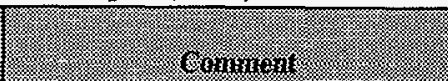 \\
\hline $\mathrm{Al}$ & 26,100 & $\mathbf{S}$ & \\
\hline $\mathrm{Bi}$ & 3,350 & $S$ & \\
\hline $\mathrm{Ca}$ & 410 & $\mathbf{S}$ & \\
\hline $\mathrm{Cl}$ & 208 & $\mathbf{S}$ & \\
\hline $\mathrm{TIC}$ as $\mathrm{CO}_{3}$ & 9,430 & $S$ & \\
\hline $\mathrm{Cr}$ & 374 & $S$ & \\
\hline $\mathbf{F}$ & 250 & $\mathbf{S}$ & \\
\hline $\mathrm{Fe}$ & 9,430 & $\mathbf{S}$ & $\therefore$ \\
\hline $\mathrm{Hg}$ & 8.28 & $E$ & Per change package 7 (Simpson 1998) \\
\hline $\mathbf{K}$ & 259 & $\mathbf{S}$ & \\
\hline $\mathrm{La}$ & 20.20 & $S$ & \\
\hline$\overline{\mathrm{Mn}}$ & 4,040 & $\mathbf{S}$ & \\
\hline $\mathrm{Na}$ & 34,500 & $S$ & \\
\hline $\mathrm{Ni}$ & 40.2 & $\mathbf{S}$ & \\
\hline $\mathrm{NO}_{2}$ & 18,220 & $s$ & ? \\
\hline $\mathrm{NO}_{3}$ & 12,700 & $\mathbf{S}$ & \\
\hline $\mathrm{OH}_{\text {TOTAL }}$ & 69,400 & $\mathbf{C}$ & Charge balance spreadsheet \\
\hline $\mathrm{Pb}$ & 237 & $\mathbf{S}$ & \\
\hline $\mathrm{PO}_{4}$ & 2,290 & $\mathbf{S}$ & ICP analysis \\
\hline $\mathbf{S i}$ & 1,920 & $S$ & \\
\hline $\mathrm{SO}_{4}$ & 5,260 & $S$ & IC analysis \\
\hline Sr & 72.5 & $S$ & \\
\hline TOC & 1,890 & $\mathbf{S}$ & \\
\hline $\mathrm{U}_{\text {TOTAL }}$ & 3,010 & $\mathbf{S}$ & \\
\hline $\mathrm{Zr}$ & 23.4 & $S$ & \\
\hline
\end{tabular}

Note:

${ }^{1} \mathrm{~S}=$ Sample-based (see Appendix B), $\mathrm{M}=\mathrm{HDW}$ model-based, $\mathrm{E}=$ engineering assessment, and $\mathrm{C}=$ calculated by charge balance; includes oxides as hydroxides, not including $\mathrm{CO}_{3}, \mathrm{NO}_{2}, \mathrm{NO}_{3}, \mathrm{PO}_{4}, \mathrm{SO}_{4}$, and $\mathrm{SiO}_{3}$. 
Table D4-2. Best-Basis Inventory Estimates for Radioactive.Components in Tank 241-U-112. Decayed to January 1, 1994 (Effective April 1, 1998). (2 sheets)

\begin{tabular}{|c|c|c|c|}
\hline 1.81 .18 & 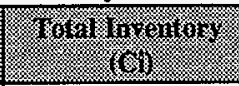 & $(5,11,8.8)$ & (.). \\
\hline${ }^{3} \mathrm{H}$ & 4.94 & $S$ & \\
\hline${ }^{14} \mathrm{C}$ & 0.41 & $\mathbf{S}$ & . \\
\hline${ }^{59} \mathrm{Ni}$ & 0.00480 & $\mathbf{M}$ & \\
\hline${ }^{60} \mathrm{Co}$ & 15.7 & $S$ & \\
\hline${ }^{63} \mathrm{Ni}$ & 0.435 & $\mathrm{M}$ & \\
\hline${ }^{79} \mathrm{Se}$ & 0.00357 & $\mathbf{M}$ & \\
\hline${ }^{90} \mathrm{Sr}$ & 115,000 & $\mathbf{S}$ & \\
\hline${ }^{90} \mathrm{Y}$ & 115,000 & $\mathbf{S}$ & Based on ${ }^{90} \mathrm{Sr}$ activity \\
\hline${ }^{93} \mathrm{Zr}$ & 0.0169 & $\mathbf{M}$ & \\
\hline${ }^{93 \mathrm{~m}} \mathrm{Nb}$ & 0.0142 & $\mathbf{M}$ & \\
\hline${ }^{99} \mathrm{Tc}$ & 153 & $\mathbf{S}$ & \\
\hline${ }^{106} \mathrm{Ru}$ & $1.88 \mathrm{E}-09$ & $M$ & \\
\hline${ }^{113 \mathrm{~m}} \mathrm{Cd}$ & 0.0426 & $\mathbf{M}$ & \\
\hline${ }^{125} \mathrm{Sb}$ & 274 & $\mathbf{S}$ & \\
\hline${ }^{126} \mathrm{Sn}$ & 0.00538 & $\mathbf{M}$ & \\
\hline${ }^{129} \mathrm{I}$ & $2.22 \mathrm{E}-04$ & $\mathbf{M}$ & \\
\hline${ }^{134} \mathrm{Cs}$ & 22.7 & $\mathbf{s}$ & \\
\hline${ }^{137} \mathrm{Cs}$ & 13,300 & $\mathbf{S}$ & \\
\hline${ }^{137 \mathrm{~m}} \mathrm{Ba}$ & 12,600 & $\mathbf{S}$ & Based on 0.946 of ${ }^{137} \mathrm{Cs}$ activity \\
\hline${ }^{151} \mathrm{Sm}$ & 13.2 & $\mathbf{M}$ & (2) \\
\hline${ }^{152} \mathrm{Eu}$ & 0.00586 & $\mathbf{M}$ & \\
\hline${ }^{154} \mathrm{Eu}$ & 737 & $\mathbf{S}$ & \\
\hline${ }^{155} \mathrm{Eu}$ & 869 & $\mathbf{S}$ & \\
\hline${ }^{226} \mathrm{Ra}$ & $8.76 \mathrm{E}-07$ & $\mathbf{M}$ & \\
\hline${ }^{277} \mathrm{Ac}$ & 4.49E-06 & $\mathbf{M}$ & \\
\hline${ }^{228} \mathrm{Ra}$ & $2.25 \mathrm{E}-11$ & $\mathbf{M}$ & \\
\hline${ }^{229} \mathrm{Th}$ & 4.37E-09 & $\mathbf{M}$ & \\
\hline${ }^{231} \mathrm{~Pa}$ & $9.88 \mathrm{E}-06$ & $\mathrm{M}$ & \\
\hline${ }^{232} \mathrm{Th}$ & $4.74 \mathrm{E}-12$ & M & . \\
\hline${ }^{232} U$ & $2.29 \mathrm{E}-05$ & $\mathrm{~S} / \mathrm{M}$ & $\begin{array}{l}\text { Based on ICP U sample result ratioed to } \\
\mathrm{HDW} \text { estimates for U isotopes }\end{array}$ \\
\hline
\end{tabular}


Table D4-2. Best-Basis Inventory Estimates for Radioactive Components in Tank 241-U-112. Decayed to January 1, 1994 (Effective April 1, 1998). (2 sheets)

\begin{tabular}{|c|c|c|c|}
\hline 4. & I & 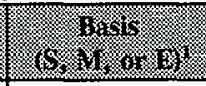 & Oaninemit \\
\hline${ }^{233} \mathrm{U}$ & $1.06 \mathrm{E}-06$ & $\mathrm{~S} / \mathrm{M}$ & $\begin{array}{l}\text { Based on ICP U sample result ratioed to } \\
\text { HDW estimates for U isotopes }\end{array}$ \\
\hline${ }^{234} \mathrm{U}$ & 0.989 & $\mathbf{S} / \mathbf{M}$ & $\begin{array}{l}\text { Based on ICP U sample result ratioed to } \\
\text { HDW estimates for U isotopes }\end{array}$ \\
\hline${ }^{235} \mathrm{U}$ & 0.0437 & $\mathbf{S} / \mathbf{M}$ & $\begin{array}{l}\text { Based on ICP U sample result ratioed to } \\
\text { HDW estimates for U isotopes }\end{array}$ \\
\hline${ }^{236} \mathrm{U}$ & 0.00983 & $S / M$ & $\begin{array}{l}\text { Based on ICP U sample result ratioed to } \\
\text { HDW estimates for U isotopes }\end{array}$ \\
\hline${ }^{237} \mathrm{~Np}$ & $7.28 \mathrm{E}-04$ & $\mathbf{M}$ & \\
\hline${ }^{238} \mathrm{Pu}$ & 0.422 & $S$ & $\begin{array}{l}\text { Based on ICP U sample result ratioed to } \\
\text { HDW estimates for U isotopes }\end{array}$ \\
\hline${ }^{238} \mathrm{U}$ & 1.01 & $\mathbf{S} / \mathbf{M}$ & $\begin{array}{l}\text { Based on ICP U sample result ratioed to } \\
\text { HDW estimates for U isotopes }\end{array}$ \\
\hline${ }^{239} \mathrm{Pu}$ & 99.1 & $\mathbf{S} / \mathbf{M}$ & $\begin{array}{l}\text { Based on alpha sample result ratioed to } \\
\text { HDW estimates for alpha isotopes }\end{array}$ \\
\hline${ }^{240} \mathrm{Pu}$ & 6.68 & $\mathbf{S} / \mathbf{M}$ & $\begin{array}{l}\text { Based on total alpha sample result ratioed } \\
\text { to HDW estimates for alpha isotopes }\end{array}$ \\
\hline $241 \mathrm{Am}$ & 99.7 & $\mathrm{~s}$ & \\
\hline${ }^{241} \mathrm{Pu}$ & 10.6 & $\mathbf{S} / \mathbf{M}$ & $\begin{array}{l}\text { Based on total alpha sample result ratioed } \\
\text { to HDW estimates for alpha isotopes }\end{array}$ \\
\hline${ }^{242} \mathrm{Cm}$ & 0.287 & $\mathbf{S} / \mathbf{M}$ & $\begin{array}{l}\text { Based on total alpha sample result ratioed } \\
\text { to HDW estimates for alpha isotopes }\end{array}$ \\
\hline${ }^{242} \mathrm{Pu}$ & $4.41 \mathrm{E}-05$ & S/M & $\begin{array}{l}\text { Based on total alpha sample result ratioed } \\
\text { to HDW estimates for alpha isotopes }\end{array}$ \\
\hline${ }^{243} \mathrm{Am}$ & 7.07E-04 & $\mathbf{S} / \mathbf{M}$ & $\begin{array}{l}\text { Based on total alpha sample result ratioed } \\
\text { to HDW estimates for alpha isotopes }\end{array}$ \\
\hline${ }^{243} \mathrm{Cm}$ & 0.00588 & $\mathbf{S} / \mathbf{M}$ & $\begin{array}{l}\text { Based on total alpha sample result ratioed } \\
\text { to HDW estimates for alpha isotopes }\end{array}$ \\
\hline${ }^{244} \mathrm{Cm}$ & 0.0168 & $\mathbf{S} / \mathbf{M}$ & $\begin{array}{l}\text { Based on total alpha sample result ratioed } \\
\text { to HDW estimates for alpha isotopes }\end{array}$ \\
\hline
\end{tabular}

Note:

${ }^{1} \mathrm{~S}=$ sample-based (see Appendix B), M = HDW model-based (Agnew et al. 1997a), $\mathrm{E}=$ engineering assessment-based. 


\section{D5.0 APPENDIX D REFERENCES}

Anderson, J. D., 1990, A History of the 200 Area Farms, WHC-MR-0132, Westinghouse Hanford Company, Richland, Washington.

Agnew, S. F., J. Boyer, R. A. Corbin, T. B. Duran, J. R. Fitzpatrick, K. A. Jurgensen, T. P. Ortiz, and B. L. Young, 1997a, Hanford Tank Chemical and Radionuclide Inventories: HDW Model Rev. 4, LA-UR-96-3860, Rev. 0, Los Alamos National Laboratory, Los Alamos, New Mexico.

Agnew, S. F., R. A. Corbin, T. B. Duran, K. A. Jurgensen, T. P. Ortiz, and B. L. Young, 1997b, Waste Status and Transaction Record Summary (WSTRS Rev. 4), LA-UR-97-311, Rev. 0, Los Alamos National Laboratory, Los Alamos, New Mexico.

Brevick, C. H., J. L. Stroup, and J. W. Funk, 1997, Historical Tank Content Estimate for the Northwest Quadrant of the Hanford 200 West Area, WHC-SD-WM-ER-351, Rev. 1, Fluor Daniel Northwest, Inc. for Fluor Daniel Hanford, Inc., Richland, Washington.

Hanlon, B. M., 1998, Waste Tank Summary Report for Month Ending February 28, 1998, WHC-EP-0182-119, Lockheed Martin Hanford Corp. for Fluor Daniel Hanford, Inc., Richland, Washington.

Hill, J. G., G. S. Anderson, and B. C. Simpson, 1995, The Sort on Radioactive Waste Type Model: A Method to Sort Single-Shell Tanks into Characteristic Groups, PNL-9814, Rev. 2, Pacific Northwest Laboratory, Richland, Washington.

Hodgson, K. M., and M. D. LeClair, 1996, Work Plan for Defining a Standard Inventory Estimate for Wastes Stored in Hanford Site Underground Tanks, WHC-SD-WM-WP-311, Rev. 1, Lockheed Martin Hanford Corp. for Fluor Daniel Hanford, Inc., Richland, Washington.

Kupfer, M. J., A. L. Boldt, B. A. Higley, K. M. Hodgson, L. W. Shelton, B. C. Simpson, R. A. Watrous, S. L. Lambert, D. E. Place, R. M. Orme, G. L. Borsheim, N. G. Colton, M. D. LeClair, R. T. Winward, and W. W. Schulz, 1997, Standard Inventories of Chemicals and Radionuclides in Hanford Site Tank Wastes, HNF-SD-WM-TI-740, Rev. OA, Lockheed Martin Hanford Corp. for Fluor Daniel Hanford, Inc., Richland, Washington.

LMHC, 1998, Best-Basis Inventory for Tank 241-T-105, Tank Characterization Database, Month, Day, Year, Internet at http://twins.pnl.gov:8001/TCD/main.html. 
Simpson, B. C., 1998, Best Basis Inventory Change Package for Reconciliation of Mercury Values, change package 7 (internal memorandum TA120-98-005 to J. W. Cammann, February 26), Lockheed Martin Hanford Corp. for Fluor Daniel Hanford, Inc., Richland, Washington.

Watrous, R. A., and D. W. Wootan, 1997, Activity of Fuel Batches Processed Through Hanford Separations Plants, 1944 Through 1989, HNF-SD-WM-TI-794, Rev. 0, Lockheed Martin Hanford Corp. for Fluor Daniel Hanford, Inc., Richland, Washington. 
HNF-SD-WM-ER-369 Rev. 2

This page intentionally left blank. 
HNF-SD-WM-ER-369 Rev. 2

;

APPENDIX E

BIBLIOGRAPHY FOR TANK 241-T-105

E-1 
HNF-SD-WM-ER-369 Rev. 2

This page intentionally left blank. 


\section{APPENDIX E \\ BIBLIOGRAPHY FOR TANK 241-T-105}

Appendix E provides a bibliography that supports the characterization of tank 241-T-105. This bibliography is an in-depth literature search of all known information sources that provide sampling, analysis, surveillance, and modeling information, as well as processing occurrences associated with tank 241-T-105 and its respective waste types.

The references in this bibliography are separated into three broad categories containing references broken down into subgroups. These categories and their subgroups are listed below.

\section{NON-ANAIYTICAL DATA}

Ia. Models/Waste Type Inventories/Campaign Information

Ib. Fill History/Waste Transfer Records

Ic. Surveillance/Tank Configuration

Id. Sample Planning/Tank Prioritization

Ie. Data Quality Objectives/Customers of Characterization Data

\section{ANALYTICAL DATA - SAMPLING OF TANK WASTE AND WASTE TYPES}

IIa. Sampling of Tank 241-T-105

IIt. Sampling of $1 \mathrm{C}, 2 \mathrm{C}$, and $\mathrm{CW}$ Waste Types

\section{COMBINED ANALYTICAL/NON-ANALYTICAL DATA}

IIIa. Inventories using Campaign and Analytical Information

IIIb. Compendium of Existing Physical and Chemical Documented Data Sources

This bibliography is broken down into the appropriate sections of material to use, with an annotation at the end of each reference describing the information source. Where possible, a reference is provided for information sources. Most of the information listed below is available in the Lockheed Martin Hanford Corporation Tank Characterization and Safety Resource Center. 


\section{NON-ANALYTICAL DATA}

Ia. Models/Waste Type Inventories/Campaign Information

Anderson, J. D., 1990, A History of the 200 Area Farms, WHC-MR-0132, Westinghouse Hanford Company, Richland, Washington.

- Contains single-shell tank fill history and primary campaign/waste type information to 1981 .

Jungfleisch, F. M., and B. C. Simpson, 1993, Preliminary Estimation of the Waste Inventories in Hanford Tanks Through 1980, WHC-SD-WM-TI-057, Rev. 0A, Westinghouse Hanford Company, Richland, Washington.

- Contains a model based on process knowledge and radioactive decay estimations for different compositions of process waste streams assembled for total solutions and solids compositions per tank. Assumptions about waste/waste types and solubility parameters/constraints are also given.

Hodgson, K. M., and M. D. LeClair, 1996, Work Plan for Defining a Standard Inventory Estimate for Wastes Stored in Hanford Site Underground Tanks, WHC-SD-WM-WP-311, Rev. 1A, Lockheed Martin Hanford, Corp. for Fluor Daniel Hanford, Inc., Richland, Washington.

- Gives a plan for defining a standard inventory estimate for wastes stored in tanks at the Hanford Site.

Schneider, K. J., 1951, Flow Sheet and Flow Diagrams of Precipitation Separations Process, Drawing HW-23043, General Electric Company, Richland, Washington.

- Contains compositions of first cycle.waste before its transfer to 200 East Area waste tanks.

\section{Ib. Fill History/Waste Transfer Records}

Agnew, S. F., R. A. Corbin, T. B. Duran, K. A. Jurgensen, T. P. Ortiz, and B. L. Young, 1997, Waste Status and Transaction Record Summary (WSTRS) Rev. 4, LA-UR-97-311, Rev. 0, Los Alamos National Laboratory, Los Alamos, New Mexico.

- Contains spreadsheets showing all available data on tank additions and transfers. 
Anderson, J. D., 1990, A History of the 200 Area Tank Farms, WHC-MR-0132, Westinghouse Hanford Company, Richland, Washington.

- Contains single-shell tank fill history and primary campaign/waste type information up to 1981 .

\section{Ic. Surveillance/Tank Configuration}

Alstad, A. T., 1993, Riser Configuration Document for Single-Shell Waste Tanks, WHC-SD-RE-TI-053, Rev. 9, Westinghouse Hanford Company, Richland, Washington.

- Shows tank riser locations in relation to tank aerial view and a description of the risers and their contents.

Bergmann, L. M., 1991, Single-Shell Tank Isolation Safety Analysis Report, WHC-SD-WM-SAR-006, Rev. 2, Westinghouse Hanford Company, Richland, Washington.

- Contains safety analysis report on isolation of single-shell tanks.

Baumhardt, R. J., 1988, Interim Isolation of Tanks 105-T, 109-T and 104-S, (letter 8856251 to R. E. Gerton, October 12), Westinghouse Hanford Company, Richland, Washington.

- Documents interim isolation of tank 241-T-105 on September 30, 1988.

Lipnicki, J., 1996, Waste Tank Risers Available for Sampling, WHC-SD-WM-TI-710, Rev. 4, Lockheed Martin Hanford Corp. for Fluor Daniel Hanford, Inc., Richland, Washington.

- Assesses riser locations for each tank; however not all tanks are included/ completed. Includes estimate of what risers are available for sampling.

Tran, T. T., 1993, Thermocouple Status Single-Shell and Double-Shell Waste Tanks, WHC-SD-WM-TI-553, Rev. 0, Westinghouse Hanford Company, Richland, Washington.

- Contains information about the status of thermocouples in Hanford Site tanks. 
Welty, R. K., 1988, Waste Storage Tank Status and Leak Detection Criteria, WHC-SD-WM-TI-356, Vol. 2, Rev. 0, Westinghouse Hanford Company, Richland, Washington.

- Describes the nature, scope, and frequency of surveillance employed for waste storage tanks, states action criteria for response to data deviations, and presents tank data reviews between June 15, 1973, and June 15, 1988. Also provides information on sample planning and tank prioritization.

Bell, K. E., 1993, Tank Waste Remediation System Tank Waste Characterization Plan, WHC-SD-WM-PLN-047, Rev. 1, Westinghouse Hanford Company, Richland, Washington.

- Provides an integrated approach to characterizing Hanford Site tank waste samples. The scope of this plan is defined by the characterization activities necessary for safely storing, maintaining, treating, and disposing onsite, or packaging for offsite disposal, all tank wastes.

Brown, T. M., J. W. Hunt, and L. J. Fergestrom, 1997, Tank Characterization Technical Sampling Basis, HNF-SD-WM-TA-164, Rev. 3, Lockheed Martin Hanford Corp. for Fluor Daniel Hanford, Inc., Richland, Washington.

- Summarizes the technical basis for characterizing tank waste and assigns a priority number to each tank.

DOE-RL, 1996, Recommendation 93-5 Implementation Plan, DOE/RL-94-0001, Rev. 1, U.S. Department of Energy, Richland, Washington.

- Describes the organic solvents issue and other tank issues.

Field, J. G., 1997, Tank 241-T-105 Push Mode Core Sampling and Analysis Plan, HNF-SD-WM-TSAP-134, Rev. OC, Lockheed Martin Hanford Corp. for Fluor Daniel Hanford, Inc., Richland, Washington.

- Contains sampling and analysis requirements for tank 241-T-105 based on applicable DQOs. 
Field, J. G., 1997, Tank 241-T-105 Sample Analysis, (internal memorandum 74620-97-213 to A. D. Rice, August 20), Lockheed Martin Hanford Corp. for Fluor Daniel Hanford, Inc., Richland, Washington.

- Contains changes and clarifications to the sampling and analysis plan for handling sodium crystals found in 1997 core samples.

Grimes, G. W., 1977, Hanford Long-Term Defense High-Level Waste Management Program Waste Sampling and Characterization Plan, RHO-CD-137, Rockwell Hanford Operations, Richland, Washington.

- Early characterization planning document.

Public Law 101-510, 1990, "Safety Measures for Waste Tanks at Hanford Nuclear Reservation," Section 3137 of National Defense Authorization Act for Fiscal Year 1991.

- Provides information regarding safety measures for waste stored in tanks at the Hanford Site.

Rich, H. S., and L. M. Sasaki, 1993, Letter of Instruction for Physical Analysis of Single-Shell Tank 241-T-105 Core 57, (letter 9355141 to A. G. King of Pacific Northwest Laboratory, June 21), Westinghouse Hanford Company, Richland, Washington.

- Provides instructions for the physical analyses of core 57 samples by the Pacific Northwest Laboratory 325 Laboratory.

Waldo, E. J., 1993, Core Sampling Recovery Test Strategy, WHC-SD-WM-TP-170, Rev. 0, Westinghouse Hanford Company, Richland, Washington.

- Contains instructions for the core sampling recovery test.

Winkelman, W. D., M. R. Adams, T. M. Brown, J. W. Hunt, D. J. McCain, L. J. Fergestrom, 1997, Fiscal Year 1997-1998 Waste Information Requirements Document, HNF-SD-WM-PLN-126, Rev. OA, Lockheed Martin Hanford Corp. for Fluor Daniel Hanford, Inc., Richland, Washington.

- Contains Hanford Federal Facility Agreement and Consent Order requirement-driven TWRS Characterization Program information. 
Winters, W. I., L. Jensen, L. M. Sasaki, R. L. Weiss, J. F. Keller, A. J. Schmidt, and M. G. Woodruff, 1989, Waste Characterization Plan for the Hanford Site Single-Shell Tanks, WHC-EP-0210, Westinghouse Hanford Company, Richland, Washington.

- Early version of characterization planning document.

Ie. Data Quality Objectives and Customers of Characterization Data

Dukelow, G. T., J. W. Hunt, H. Babad, and J. E. Meacham, 1995, Tank Safety Screening Data Quality Objective, WHC-SD-WM-SP-004, Rev. 2, Westinghouse Hanford Company, Richland, Washington.

- DQO used to determine whether tanks operate under safe conditions.

Meacham, J. E., D. L. Banning, M. R. Allen, and L. D. Muhlestein, 1997, Data Quality Objective to Support Resolution of the Organic Solvent Safety Issue, HNF-SD-WM-DQO-026, Rev. 0, DE\&S Hanford, Inc. for Fluor Daniel Hanford, Inc., Richland, Washington.

- Contains requirements for the organic solvents DQO.

Osborne, J. W., and L. L. Buckley, 1995, Data Quality Objectives for Tank Hazardous Vapor Safety Screening, WHC-SD-WM-DQO-002, Rev. 2, Westinghouse Hanford Company, Richland, Washington.

- Contains requirements for addressing hazardous vapor issues.

Schreiber, R. D., 1997, Memorandum of Understanding for the Organic Complexant Safety Issue Data Requirements, HNF-SD-WM-RD-060, Rev. 0, Lockheed Martin Hanford Corp. for Fluor Daniel Hanford, Inc., Richland, Washington.

- Contains requirements, methodology, and logic for analyses to support organic complexant issue resolution. 


\section{ANALYTICAL DATA - SAMPLING OF TANK WASTE AND WASTE TYPES}

IIa. Sampling of Tank 241-T-105

Cromar, R. D., S. R. Wilmarth, and L. Jensen, 1994, Statistical Characterization Report for Single-Shell Tank 241-T-105, WHC-SD-WM-TI-653, Rev. 0

Westinghouse Hanford Company, Richland, Washington.

- Contains statistical characterization report for tank 241-T-105.

Esch, R. A., 1997, Tank 241-T-105, Cores 205 and 207 Analytical Results for the Final Report, HNF-SD-WM-DP-265, Rev. 0, Waste Management Federal Services of Hanford, Inc. for Fluor Daniel Hanford, Inc., Richland, Washington.

- Contains laboratory results for 1997 push core sample analyses.

Giamberardini, K. K., 1993, 222-S Laboratories Single-Shell Tank Waste Characterization, Tank-T-105 Core 57 Data Package, WHC-SD-WM-DP-040, Rev. OB, Westinghouse Hanford Company, Richland, Washington.

- Contains data package for core 57.

Godfrey, W. L., 1965, 242-T Evaporator Feed, (internal letter to S. J. Beard, September 24), General Electric Company, Richland, Washington.

- Contains 242-T Evaporator feed analytical results.

Herting, D. L., 1993, Mass/Charge Balance for Tank T-105, (internal memorandum 12110-PCL93-084 to K. L. Kocher, September 28), Westinghouse Hanford Company, Richland, Washington.

- Contains mass and charge balance for $\operatorname{tank} 241-T-105$. The calculations are based on the 1993 sampling event.

Kocher, K. L., 1993, WHC-222-S and PNL Laboratories Single-Shell Tank Waste Characterization, Tank T-105 Cores 53 and 54 Data Packages (Narrative) and Validation Summaries, WHC-SD-WM-DP-047, Rev. OB, Westinghouse Hanford Company, Richland, Washington.

- Contains data packages for the data from cores 53 and 54, obtained from tank 241-T-105 in 1993. 
Sasaki, L. M., and H. S. Rich, 1993, Letter of Instruction for Extrusion of Core Samples During Core Sampling Recovery Testing, (internal memorandum 7K220-93-045 to J. G. Kristofzski, May 24), Westinghouse Hanford Company, Richland, Washington.

- Provides instructions to the 222-S Laboratory for extrusion of sample.

Sasaki, L. M., and H. S. Rich, 1993, Letter of Instruction on Tank 241-T-105 Core 57 Analytical Requirements, (internal memorandum 7K220-93-052 to J. G. Kristofzski, June 16), Westinghouse Hanford Company, Richland, Washington.

- Provides confirmation of sample being sent to 325 Laboratory.

Silvers, K. L., and L. M. Sasaki, 1993, Letter of Instruction for Tank T-105 Analysis Priorities, (internal memorandum 7K220-93-022 to K. L. Kocher, April 20), Westinghouse Hanford Company, Richland, Washington.

- Prioritizes the analyses of samples collected in 1993.

Wheeler, R: E., 1974, Analysis of Tank Farm Samples Sample: T-4927, 105T, Atlantic Richfield Hanford Company, Richland, Washington.

- Documents the analysis of sample T-4927.

Ib. Sampling of 1C, 2C, and CW Waste Types

Remund, K. M., J. M. Tingey, P. G. Heasler, J. J. Toth, F. M. Ryan, S. A. Hartley, and C. J. Benar, 1997, Tank Characterization Report for Single-Shell Tank 241-B-111, WHC-SD-WM-ER-549, Rev. 1A, Westinghouse Hanford Company, Richland, Washington.

- Provides characterization information and interprets the data from sampling events of tank 241-B-111. Typical example of $2 \mathrm{C}$ waste type. 


\section{COMBNED ANALYTCAL/NON-ANALYTICAL DATA}

IIIa. Inventories from Campaign and Analytical Information

Agnew, S. F., J. Boyer, R. A. Corbin, T. B. Duran, J. R. Fitzpatrick, K. A. Jurgensen, T. P. Ortiz, and B. L. Young, 1997, Hanford Tank Chemical and Radionuclide Inventories: HDW Rev. 4, LA-UR-96-858, Rev. 0, Los Alamos National Laboratory, Los Alamos, New Mexico.

- Contains waste type summaries and primary chemical compound/analyte and radionuclide estimates for sludge, supernatant, and solids.

Allen, G. K:, 1976, Estimated Inventory of Chemicals Added to Underground Waste Tanks, 1944 - 1975, ARH-CD-601B, Atlantic Richfield Hanford Company, Richland, Washington.

- Contains major components for waste types and some assumptions. Purchase records are used to estimate chemical inventories.

Allen, G. K., 1975, Hanford Liquid Waste Inventory As Of September 30, 1974, ARH-CD-229, Atlantic Richfield Hanford Company, Richland, Washington.

- Contains major components for waste types, and some assumptions.

Brevick, C. H., J. L. Stroup, and J. W. Funk, 1997, Historical Tank Content Estimate for the Southwest Quadrant of the Hanford 200 Area, WHC-SD-WM-ER-351, Rev. 1, Fluor Daniel Northwest, Inc. for Fluor Daniel Hanford, Inc., Richland, Washington.

- Contains summary information from the supporting document as well as in-tank photograph collages and the solid composite inventory estimates Rev. 0 and Rev. 0A.

Schmittroth, F. A., 1995, Consequence Ranking of Radionuclides in Hanford Tank Wastes, WHC-SD-WM-RPT-163, Rev. 0, Westinghouse Hanford Company, Richland, Washington.

- Contains radionuclide analyses for Hanford tanks. 


\section{IIIb. Compendium of Data from Other Documented Physical and Chemical Data} Sources

Agnew, S. F., and J. G. Watkin, 1994, Estimation of Limiting Solubilities for Ionic Species in Hanford Waste Tank Supernates, LA-UR-94-3590, Los Alamos National Laboratory, Los Alamos, New Mexico.

- Gives solubility ranges used for key chemical and radionuclide components based on supernatant sample analyses.

Brevick, C. H., L. A. Gaddis, and E. D. Johnson, 1996, Tank Waste Source Term Inventory Validation, Vol I \& II., WHC-SD-WM-ER-400, Rev. OA, Westinghouse Hanford Company, Richland, Washington.

- Contains a quick reference to sampling information in spreadsheet or graphical form for 23 chemicals and 11 radionuclides for all tanks.

Brevick, C. H., J. L. Stroup, and J. W: Funk, 1997, Supporting Document for the Historical Tank Content Estimate for T Tank Farm, WHC-SD-WM-ER-320, Rev. 1, Westinghouse Hanford Company, Richland, Washington.

- Document contains historical data and solid inventory estimates. The appendices contain the following information: Appendix C - Level History AutoCAD sketch; Appendix D - Temperature Graphs; Appendix E - Surface Level Graph; Appendix F-Tank Riser location; Appendix G - In-Tank Photographs.

Colton, N. G., 1996, Status Report: Pretreatment Chemistry Evaluation-Wash and Leach Factors for the Single-Shell Tank Waste Inventory, PNNL-1129, Pacific Northwest National Laboratory, Richland, Washington.

- Contains sludge wash data for all single-shell tanks evaluated since 1986.

De Lorenzo, D. S., A. T. Dicenso, D. B. Hiller, K. W. Johnson, J. H. Rutherford, D. J. Smith, and B. C. Simpson, 1994, Tank Characterization Reference Guide, WHC-SD-WM-648, Rev. 0A, Westinghouse Hanford Company, Richland, Washington.

- Provides a broad background of information relating to the characterization of Hanford Site tank wastes. 
Dukelow, G. T., 1975, Increasing Dry Well Radiation Levels Adjacent to Waste Tanks T-105 \& T-108, OR-75-02, Atlantic Richfield Hanford Company, Richland, Washington.

- Contains information about increased radiation in dry well 50-04/05-10.

Hanlon, B. M., 1998, Waste Tank Summary Report for Month Ending February 28, 1998, HNF-EP-0182-119, Lockheed Martin Hanford Corp. for Fluor Daniel Hanford, Inc., Richland, Washington.

- Contains a monthly summary of the following: fill volumes, Watch List tanks, occurrences, integrity information, equipment readings, equipment status, tank location, and other miscellaneous tank information.

Hartley, S. A., G. Chen, C. A. Lopresti, T. A. Ferryman, A. M. Liebetrau, K. M. Remund, and S. A. Allen, 1996, A Comparison of Historical Tank Contents Estimates (HTCE) Model, Rev. 3, and Sample Based Estimates, PNNL-11429, Pacific Northwest National Laboratory, Richland, Washington.

- Contains a statistical evaluation of the HDW inventory estimate against analytical values from 12 existing TCR reports using a select component data set.

Husa, E. I., 1993, Hanford Site Waste Storage Tank Information Notebook, WHC-EP-0625, Westinghouse Hanford Company, Richland, Washington.

- Contains in-tank photographs and summaries on the tank description, leak detection system, and tank status.

Husa, E. I., 1995, Hanford Waste Tank Preliminary Dryness Evaluation, WHC-SD-WM-TI-703, Rev. 0, Westinghouse Hanford Company, Richland, Washington.

- Assesses relative dryness between tanks.

Jensen, H. F., 1974, Symptoms of Leakage from Liquid Level Drop and Dry Well Activity in Waste Tank T-105, OR-74-108, Atlantic Richfield Hanford Company, Richland, Washington.

- Contains information about increased radiation in dry well 50-09-10. 
Remund, K. M., and B. C. Simpson, 1996, Hanford Waste Tank Grouping Study, PNNL-11433, Pacific Northwest National Laboratory, Richland, Washington.

- Contains a statistical evaluation to group tasks into classes with similar waste properties.

Shelton, L. W., 1996, Chemical and Radionuclide Inventory for Single- and Double-Shell Tanks, (internal memorandum 74A20-96-30, to D. J. Washenfelder, February 28), Westinghouse Hanford Company, Richland, Washington.

- Contains an tank inventory estimate based on analytical information.

Shelton, L. W., 1995, Chemical and Radionuclide Inventory for Single- and Double-Shell Tanks, (internal memorandum 75520-95-007, to R. M. Orme, August 8), Westinghouse Hanford Company, Richland, Washington.

- Contains a tank inventory estimate based on analytical information.

Shelton, L. W., 1995, Radionuclide Inventories for Single- and Double-Shell Tanks, (internal memorandum 71320-95-002 to F. M. Cooney, February 14), Westinghouse Hanford Company, Richland, Washington.

- Contains a tank inventory estimate based on analytical information. 


\section{DISTRIBUTION SHEET}

\begin{tabular}{|c|c|c|c|c|c|}
\hline \multirow{2}{*}{ Do $\quad$ Distribution } & \multirow{2}{*}{\multicolumn{3}{|c|}{$\begin{array}{l}\text { Data Asse } \\
\text { Interpr }\end{array}$}} & \multicolumn{2}{|l|}{ Page 1 of 2} \\
\hline & & & & Date $\quad 0$ & $7 / 98$ \\
\hline \multicolumn{4}{|c|}{ Project Title/Work Order } & \multicolumn{2}{|l|}{ EDT No. $N / A$} \\
\hline \multicolumn{4}{|c|}{$\begin{array}{l}\text { Tank Characterization Report for Single-She1] Tank 241-T-105, } \\
\text { HNF-SD-WM-ER-369, Rev..2 }\end{array}$} & \multicolumn{2}{|c|}{ ECN No. ECN-643788 } \\
\hline \multicolumn{2}{|l|}{ Name } & $\begin{array}{l}\text { Text } \\
\text { With All } \\
\text { Attach. }\end{array}$ & Text Only & $\begin{array}{l}\text { Attach./ } \\
\text { Appendix } \\
\text { Only }\end{array}$ & $\begin{array}{l}\text { EDT/ECN } \\
\text { Only }\end{array}$ \\
\hline
\end{tabular}

\section{OFFSITE}

Sandia National Laboratory

P.0. Box 5800

MS-0744, Dept. 6404

A7buquerque, NM 87815

D. Powers

Nuclear Consulting Services Inc.

P. 0. Box 29151

Columbus, $\mathrm{OH}$ 43229-01051

J. L. Kovach

Chemical Reaction Sub-TAP

P.0. Box 271

Lindsborg, KS 67456

B. C. Hudson

SAIC

555 Quince Orchard Rd. . Suite 500

Gaithersburg, MD 20878-1437

H. Sutter

$x$

Los A7amos Laboratory

CST-14 MS-J586

P. 0 . Box 1663

Los Alamos, NM 87545

S. F. Agnew

$x$

Tank Advisory Panel

102 Windham Road

Oak Ridge, TN 37830

D. 0. Campbe11 


\section{DISTRIBUTION SHEET}

\begin{tabular}{|c|c|c|c|c|c|}
\hline \multirow{2}{*}{ To $\quad$ Distribution } & \multirow{2}{*}{\multicolumn{3}{|c|}{ From }} & \multicolumn{2}{|l|}{ Page 2 of 2} \\
\hline & & & & Date $\quad 0$ & $7 / 98$ \\
\hline \multicolumn{4}{|c|}{ Project Title/Work Order } & \multicolumn{2}{|c|}{ EDT No. N/A } \\
\hline \multicolumn{4}{|c|}{$\begin{array}{l}\text { Tank Characterization Report for Single-Shell Tank 241-T-105, } \\
\text { HNF-SD-WM-ER-369, Rev. } 2\end{array}$} & \multicolumn{2}{|c|}{ ECN No. ECN-643788 } \\
\hline Name & MSIN & $\begin{array}{c}\text { Text } \\
\text { With All } \\
\text { Attach. }\end{array}$ & Text Only & $\begin{array}{l}\text { Attach./ } \\
\text { Appendix } \\
\text { Only }\end{array}$ & $\begin{array}{l}\text { EDT/ECN } \\
\text { Only }\end{array}$ \\
\hline
\end{tabular}

\section{ONSITE}

Department of Enerqy - Richland Operations

J. F. Thompson

W. S. Liou

J. A. Poppiti

$57-54$

$57-54$

$57-54$

$x$
$\hat{x}$
$x$

DE\&S Hanford, Inc.
R. J.Cash
W. L. Cowley
G. D. Johnson
J. E. Meacham

S7 -14

RI -49

S7-14

S7 -14

$$
\begin{aligned}
& x \\
& X \\
& x \\
& X
\end{aligned}
$$

Fluor Daniel Northwest

E. D. Johnson

S2-47

$X$

Lockheed Martin Hanford, Corp.

J. G. Burton

J. W. Cammann

S7-21

R2-11

R2 -12

$\mathrm{S} 7-84$

J. G. Field

W. E. Ross

L. M. Sasaki

B. C. Simpson

R. R. Thompson

ERC (Environmental Resource Center)

$\mathrm{R} 2-12$

$\mathrm{R} 2-12$

R2 -12

RI -51

T.C.S.R.C.

R1 -10

$$
\begin{aligned}
& X \\
& X \\
& X \\
& X \\
& X \\
& X \\
& X \\
& X \\
& 5
\end{aligned}
$$

Lockheed Martin Services. Inc.

\section{B. G. Lauzon \\ Central Fjles \\ EDMC}

R1-08

B1-07

H6-08

Numatec Hanford Corporation
J.. S. Garfield
D. L. Herting
J. S. Hertze1
D. L. Lamberd

$45-49$

T6-07

H5-61

H5-61

$X$
$X$
$X$

Pacific Northwest National Laboratory

A. F. Noonan

$K 9-91 \quad x$ 